Historic, Archive Document

Do not assume content reflects current scientific knowledge, policies, or practices. 



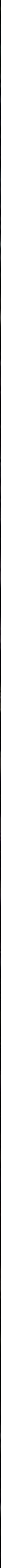




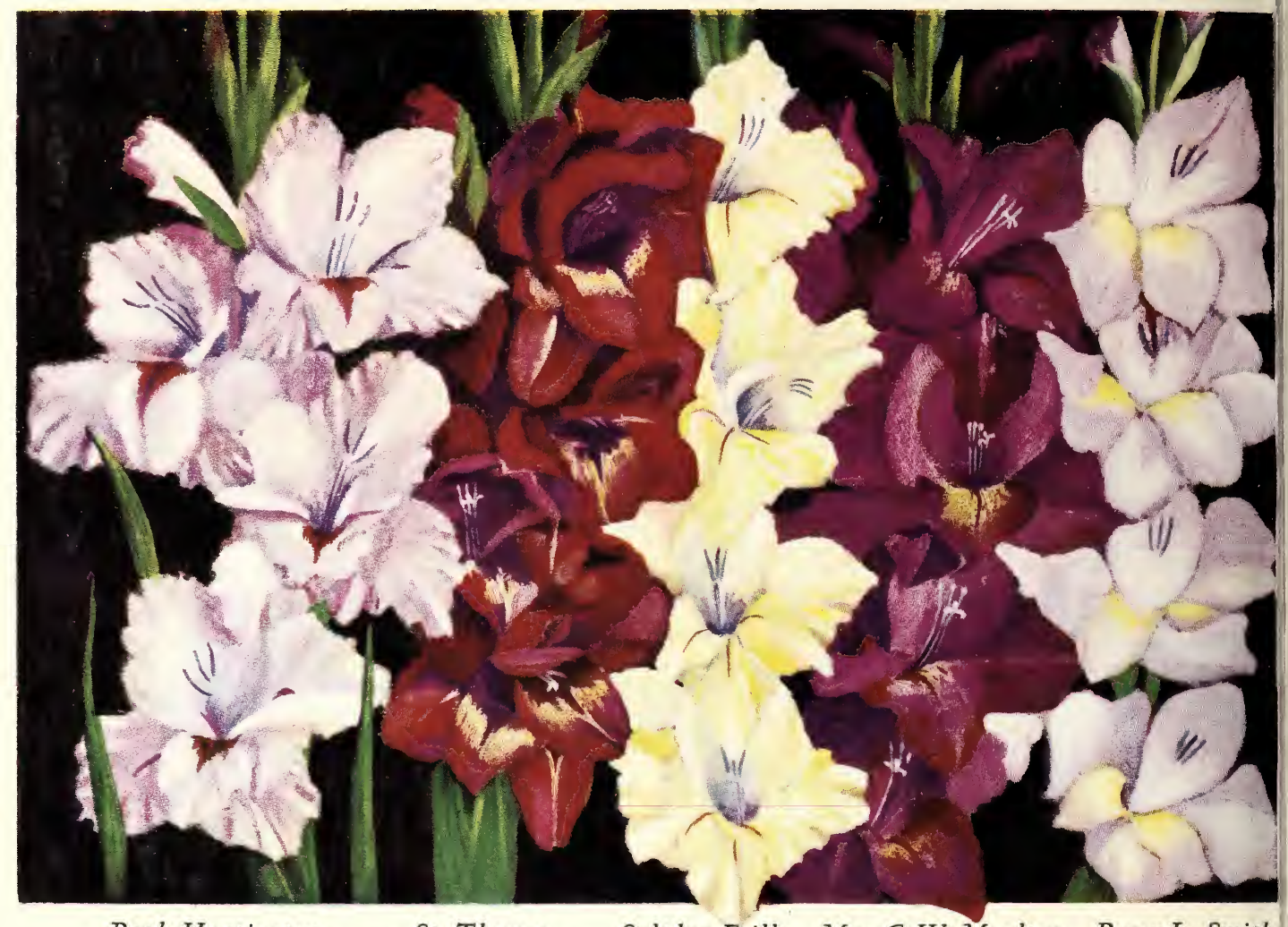

Rutb Huntington

St. Thomas

Sulphur Frills

Bryon L. Smith Reproductions from oil paintings.
Jobn T. Pirie
Twilight
Gaiety
Magic
Purple Glory

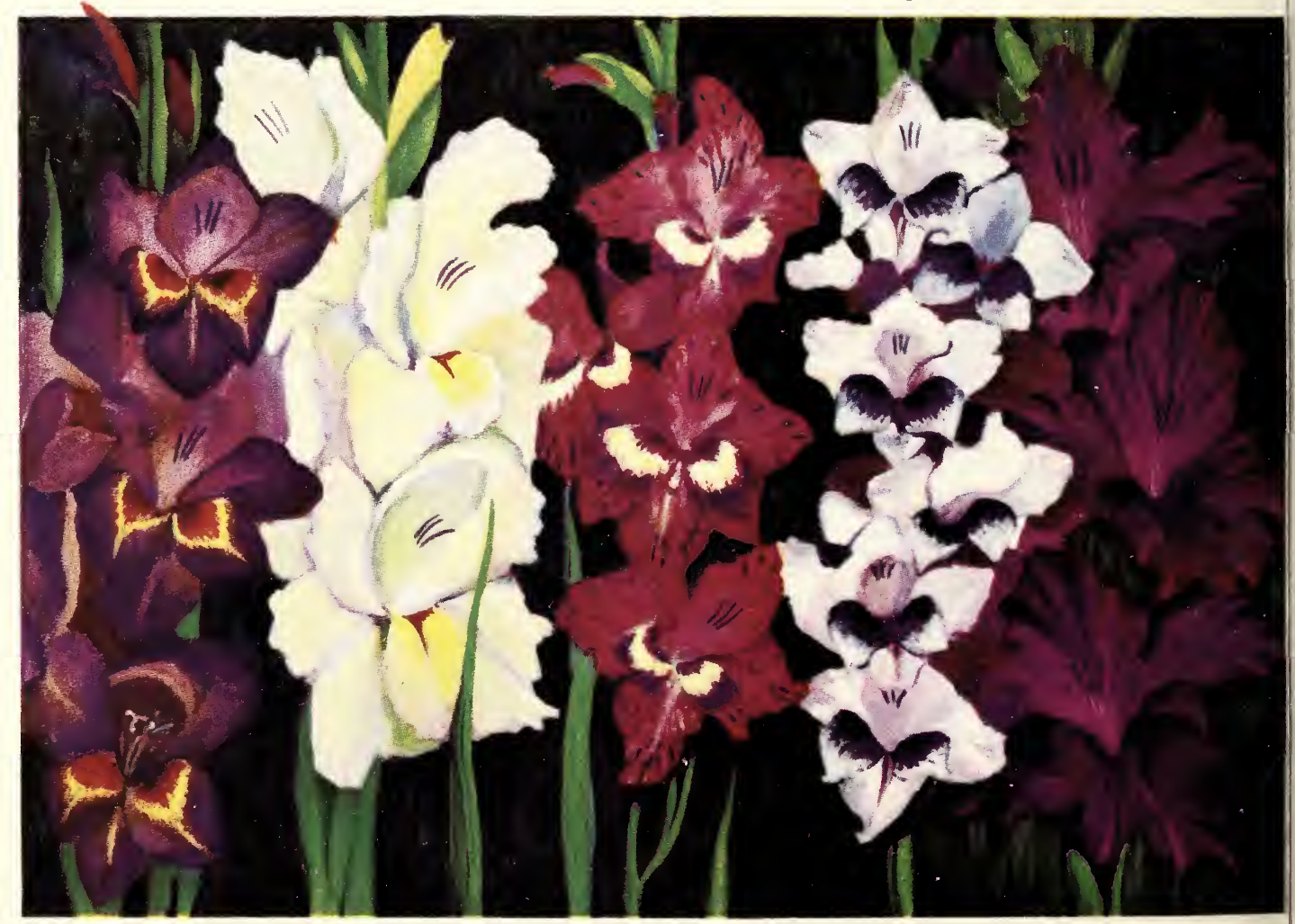




\section{GREET YOU}
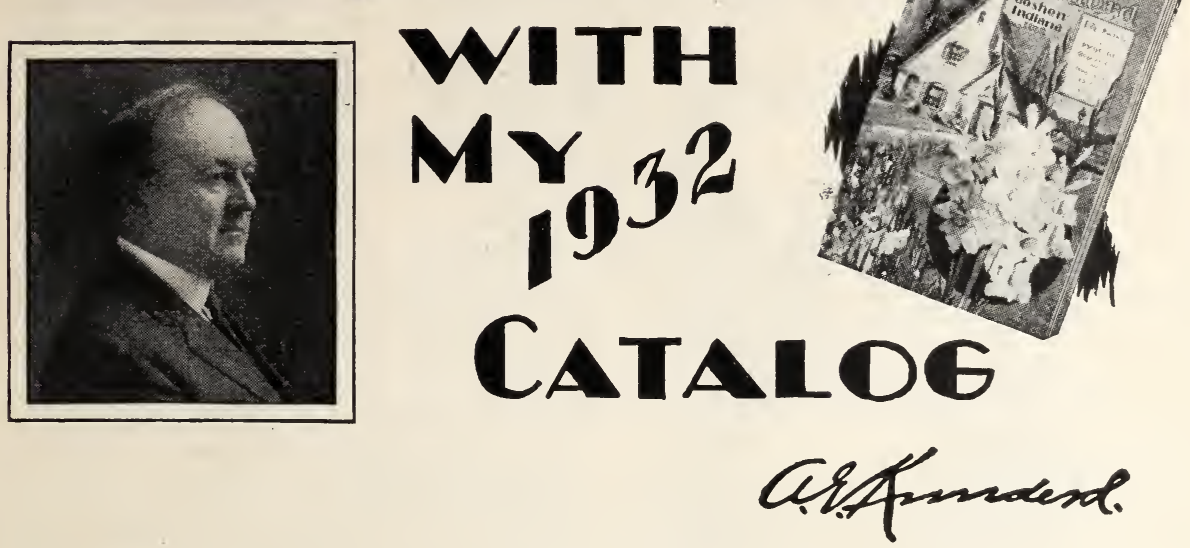

This year you will find many changes in my catalog. Alterations and additions have been made which greatly facilitate the matter of ordering Gladioli. The named varieties and collections are so extensive that every Gladiolus need can be supplied. Important too, is the fact that in the face of present extremely low prices, Kunderd Gladioli represent much the greatest value. I wish to make it very clear to my customers that the quality they always enjoyed in my bulbs has not been sacrificed in a single instance in spite of the vastly lower prices this year.

Flower lovers, here and abroad, have looked to me for years for the finest things in Gladioli and I will not fail them. From the smallest to the largest

growers the highest quality has been expected and they must not be disap. pointed. I have never been tempted to sacrifice Kunderd quality in order to lower my prices to the level of inferior goods. A customer gains nothing by buying such merchandise-it has no place in my catalog.

My catalog will satisfy your desire to get the most for every dollar you spend. My varieties will satisfy your ambition to have the best in Gladioli from the standpoint of beauty, quality and type. It is with a great deal of pride that I present you with this catalog which has listed in it the varieties of Gladioli that have won more times, in more shows, under more judges than all other Gladioli in the world combined.

\section{$1880-1932$ 52 YEARS ito}




\section{A New DEPARTMENT}

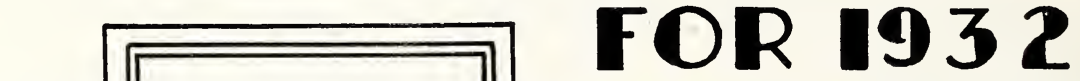

throughout. In collection form they are priced at the minimum - in fact, my collections set a new standard of Gladiolus value. The task of ordering, even for those unfamiliar with my catalog, has been made a very simple one. The individual descriptions reveal that your preferences for color, types, mixtures and prices have been met. I am sure this new department will be a delight to

Y NEW department, consisting of 1 a large number of highest quality collections, is really an innovation and a demonstration of my ability to better serve my customers. Were it not for the fact that my Gladiolus farms have become one of the largest and by far the finest in the world, these collections would have been absolutely impossible. From this huge, magnificent panorama of colors, consisting of more than 8,500 kinds growing separately and upwards of 20,000 grown in mixture and hundreds of thousands of new seedlings that have bloomed for the first time, I have been able to make selections for these various collections. My mam. moth trial grounds, the largest in the world, makes it possible for me to choose varieties and types, to such an extent, that it is far beyond the approach of any competition.

Beginning on page 9 you will find these extraordinary collections. Read them carefully for they completely solve the problem of what to buy. They are designed to meet every Gladiolus need and desire. Highest quality prevails many of my customers who have found it difficult to order in the past. How. ever, if there are particular needs you may have, I welcome most heartily your correspondence.

I want to impress upon you that I have this season harvested a most unusually fine crop of Gladiolus bulbs.

Below is an effective arrangement of Primulinus Gladiolus, combined with a small amount of Baby's Breath. One should experience no difficulty in making up baskets of equal beauty.

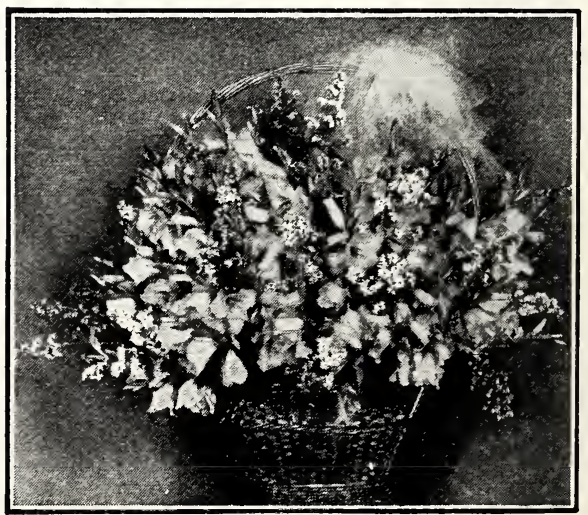




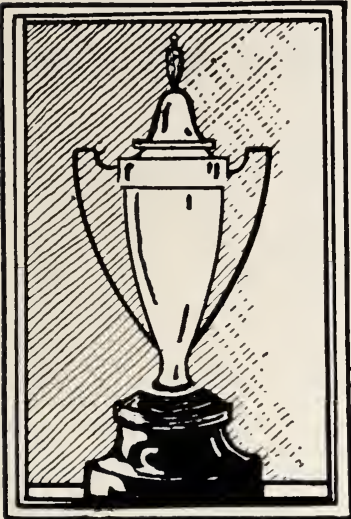

Gladiolus shows are held for the purpose of bringing out the best quality. Prizes are awarded simply to identify the best. Competition is open to anyone and everyone and judges are selected from various parts of the world and are chosen upon their recognized ability and knowledge of gladioli.

I will mention here only a few of the many awards granted these improved and popular gladioli: At the American Gladiolus Society's annual exhibit, at St. Thomas, On. tario, two of my varieties, Purple Glory and Marshal Foch, were awarded the highest hon. ors, while at Boston Fern Kyle and E. J. Shaylor won highest awards. At Kalamazoo Kunderd Gladioli won the Mitchell Silver Medal for the largest and finest collection. The A. G. S. Medal for the best collection of primulinus hybrids, and the Garden Club of America's Medal for the best new seed. ling. At the New England Gladiolus Society's show at Boston an exhibit of over 200 varieties won first for (by far) the larg. est and finest collection and an extra medal for special merit. Mr. Charles E. Ring of Toronto, Ont., offered a special 36-inch cup on a beautiful genuine ebony base "in honor of A. E. Kunderd and his work" for the best spike at the summer show at Toronto. The cup was awarded for Purple Glory. (Purple Glory is a Kunderd Variety.) At the annual exhibition of the Ontario Agricultural Col. lege, Guelph, Ont., the St. Thomas Horticultural Society won first place for best spike with Mrs. Dr. Norton (also a Kunderd variety), and the first with the best decorated hamper with Kunderd's "Salmon Beauty." At the Iowa State Fair, Des Moines, Iowa, where $\$ 500.00$ in cash was awarded, over 200 Kunderd varieties (exhibited by one of our customers) easily won first. At the an. nual Gladiolus show at Indianapolis, Purple Glory again won first place, for best variety at the show, and Kunderd's Primulinus Hybrids took first award and were in great favor with the visiting public. At the Iowa State Fair where $\$ 1,500.00$ was awarded, Kunderd Gladioli received most of the awards and were the principal talk at the show.

At the A. G. S. National Show at Rochester, New York, Kunderd awards were as follows: (47 first prizes.)

President's Cup for the largest and finest display.

Achievement Medal, for the largest total number of points.

Silver Medal, for best display of Primulinus Grandiflora.

Gold Medal, first prize, for best display of Gladioli, Primulinus type.

Silver Cup, Executive Committee's first prize, for best five baskets.

Medal, first prize, for best basket of Gladioli, exhibition type.

Medal, first prize, best basket of Gladioli commercial type.

Medal, first prize, best basket Gladioli Primulinus type.

Medal, first prize, best basket Gladioli Prim. Grandiflora type.

Fourteen additional trophies were captured at this show.

At the Sesquicentennial, Philadelphia, in 1926 I planted 68,200 of my choicest Gladioli which created a sensation and for which I was awarded a special certificate and gold medal "for meritorious achievement."

At the National Gladiolus Show at Des Moines, fifty-five growers combined their ex. hibits to defeat my exhibit, but in spite of this fact, Kunderd Gladioli easily won all principal prizes as well as other big prizes. At this show I again won the President's cup, Achievement Medal and final check showed 177 points scored, a sweeping victory for Kunderd Gladioli.

At Toledo, Ohio, another National A. G. S. Show, I again scored as heavily as in previous events, capturing the President's cup, Achievement Medal as well as other trophies and firsts.

In 1930 I staged the greatest one man Gladiolus Show ever held anywhere in the world and metropolitan newspapers carried the story to all parts of America. 


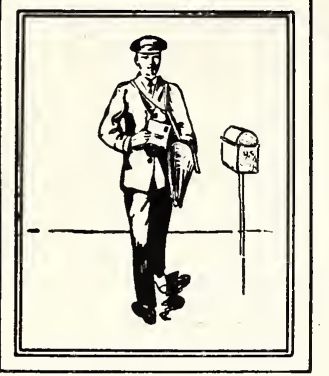

SPECIAL INFORMATION

\section{Why Kunderd Bulbs \\ Are Superior}

NE very important matter which I wish to impress on the minds of my patrons and all who wish to grow superior Gladioli is the quality of the bulbs they buy. It seems to me that a great many people are of the opinion that Gladiolus bulbs have equal merit regardless of where they are purchased. They seem to think that a bulb representing the Gladiolus Mrs. Frank Pendleton, for instance, would be the same, no matter where it is obtained. This is a mistake as results too often prove. Gladiolus bulbs vary in quality as greatly as do fruits and vegetables, or clothing, shoes and many other things. One farmer may produce beautiful Northern Spies or Kings by careful cultivation, spraying and by special knowledge of growing fine fruit, while his neighbor may produce these same varieties of apples, but of much inferior quality. It is even more important to buy QUALITY GLADIOLUS BULBS as results are far superior and quality bulbs can give best results for at least several years longer.

In Holland they grow the best tulips. The world concedes this to the Dutch people. It is not only because they have better climate and soil, but because they have learned how to properly grow and cure their bulbs. No other country in the world has learned to do this nearly so well. Expensive equipment is also a part of their scheme in producing the finest and most marvelous tulips in the world.

Similarly, Kunderd bulbs, in this country, have the reputation of being the best. This reputation was not gained by chance, but by experience in growing, storing, curing and other essential knowledge of details in pre. paring bulbs for best results. This, of course, assisted by the best equipment science has evolved.

Kunderd Gladioli have won more times, under more judges, in more shows than all other Gladioli combined. A large percentage of these awards were won by my customers who buy their bulbs direct from me each season. In order to make this possible for my customers, it was necessary to supply them with the best foundation stocks plus superior Gladiolus varieties.

More than fifty years ago I commenced the growing and culture of Gladiolus and the study of their requirements. Today, I have the foremost Gladiolus farm and grow the largest number of named kinds, all of my own originations, and do my hybridizing in the largest Gladiolus trial grounds in the world. My first great ambition was to sup. ply my customers with the finest varieties, and my next great ambition was to supply the finest quality bulbs, and results in the hands of my customers all over the world have proven that I have accomplished both.

From the beginning there were problems by the score. Like an inventor, I had to try new things and year after year I had to make many tests. I learned, to my satisfaction, that soil and climate conditions in Northern Indiana are ideal for the growing of Gladiolus bulbs commercially. Therefore I feel that bulbs produced in this particular area are better adapted for planting in your garden as these bulbs will do especially well planted elsewhere. Soil conditions, growing conditions, digging, planting, storing, curing and handling at every stage of prepar. ing bulbs of highest quality, all contributed their own particular problems. Coping with these problems to best solve them meant the purchase of expensive equipment. At present I have the largest, finest and most perfectly equipped buildings in America for the purpose of curing and care of my bulbs. I wish to impress upon you that the curing of bulbs is the most important step in producing bulbs that will give the best results to the customer. Like Holland produces the finest tulips by the most careful attention to

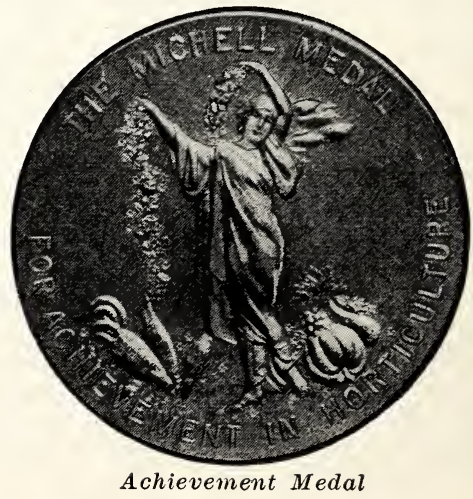

\section{To Have the Best, Be Sure You Buy Your Bulbs from Kunderd}


every detail, we produce the best Gladiolus Bulbs by the same means.

The planting of bulbs is important espe. cially when planting is done on a large scale. Before we plant we make sure that the ground has been carefully prepared. The fields are conditioned for four years then they are worked up in a most careful manner. A uniform plowing is done with Cater pillar tractors. This is followed by the most thorough harrowing from the disc to the spring tooth; then the spike tooth harrow, and when the soil is finally in perfect condition, the planting is done. I do not overfertilize my fields, as this merely adds to plant growth rather than develop choice bulbs. It is my policy to use land which is just normally good in order that when the bulb comes from the ground and has not been overforced it will give better results to the customer in whose garden it is prob. ably going to be better fed and do its very best.

We do not cut and ship flowers to the market, as is the case almost invariably with commercial Gladiolus growers because the market insișts upon long stems, and the com. petition is so keen that anyone sending short stemmed Gladioli to market gets a very low price, or frequently nothing for his stock. Gladiolus bulbs the country over are being robbed of their strength through the abuse of commercial growers who cut the flower spikes as long as possible, and the bulb can. not do justice in the gardens of the average grower buying such stock. My entire flower crop is cut off a short way below the lower blossom, thus leaving every leaf and the stem, necessary for the full growth and de. velopment of the very best possible bulbs which can be produced.

One of the greatest factors in growing bulbs which will give the customer best $\mathrm{re}^{\text {- }}$ sults is that they be grown from bulblets (or cormlets) to blooming size, and not from bulbs which may have been grown from year to year from old bulbs. Bulbs grown in this way are far superior to bulbs grown from older bulbs and are of greater value over a longer period of years. This also explains why vigorous young bulbs, even of smaller size, are far superior to old bulbs, no matter how large and showy these may be.

Of course, the fields are frequently culti. vated with whatever form of tool we find necessary from time to time, and the ground is kept absolutely free from weeds, as thou. sands of visitors who have seen my fields, will gladly testify, thus, giving the Gladioli the entire ground to themselves.

No one knows better than the seller what his goods are worth, and a quality product merits a reasonable difference in price. Inferior quality is usually expensive at any price. I am glad to serve those who want the best.

My explanation of my methods of curing and handling does not apply to the small grower, as the comparatively few bulbs do not given rise to difficulties. My cultural directions, found elsewhere in this book will explain how easily and efficiently you can raise prize-winning Gladioli in your own garden.

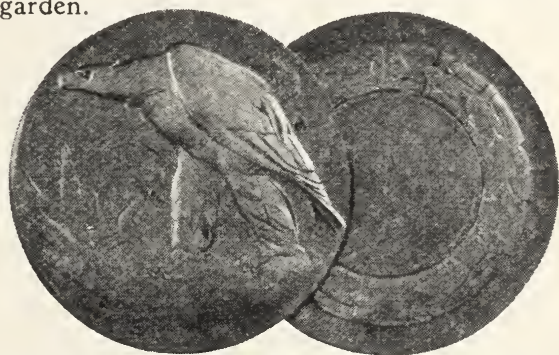

Grand Award, Sesquicentennial Exposition, Philadelphia, 1926
Gabriel Hunt, New York.

The bulbs arrived safely, and we are very pleased with them.

We were quite interested in the way they were packed, and know by the time it took us to undo them that it is quite a lot of work to put them all up individually.

We wish to thank you very much for the extras, also for the substitutes which I see are of more value.

Mrs. W. Haynes, Calif., March 11, 1931.

I feel I am taking an unfair advantage of your offers from time to time, and I regret that I have not more garden space in which to plant more of your wonderful bulbs and seeds. Some Iris I got from you two years ago are dolng wonderful this year.

I am delighted and more than satisfied with everything I have purchased, or rather bulbs you have almost given me.

\section{H. Kitchener, Canada. February 20, 1931.}

I have about 10,000 Glads this year-all from vour stock. I might state they are the most wonderful Glads that ever I grew. I hope to buy next year. I am growing for the cut bloom trade, only I might state I have grown Glads for a good few years in England, but Kunderd's has them beat by far.
F. H. Illig, Pa., June 13, 1931.

I want to tell you my experience and how much I like Kunderd's bulbs. I bought bulbs from three different places besides yours this spring. Two were located in Ohio and one in Oregon state.

I planted your bulbs at the same time I did those from the other concerns; $96 \%$ of Kunderd's bulbs came up, $70 \%$ of the Oregon bulbs and $83 \%$ from the two concerns in Ohio. Furthermore, the Glads that you sent me are 6 " higher than any of the other Glads, and are healthier and stronger looking plants. It proves that something cheap is most expensive in the long rome

Lydia Klemz, Wis. February 28, 1931.

Just a personal word of appreciation of your wonderful achievement in your ability of giving pleasure to so many-rich and poor (that's me), well and sick-all alike. How very happy it must make you. May you be spared many years. The world needs you.

Miss Alma M. Kugelmann, New Jersey.

The Gladiolus bulbs I purchased from you last year surpassed my expectations entirely. The blooms were gorgeous and while my garden is only a small one, everyone thought it a very lovely one. 


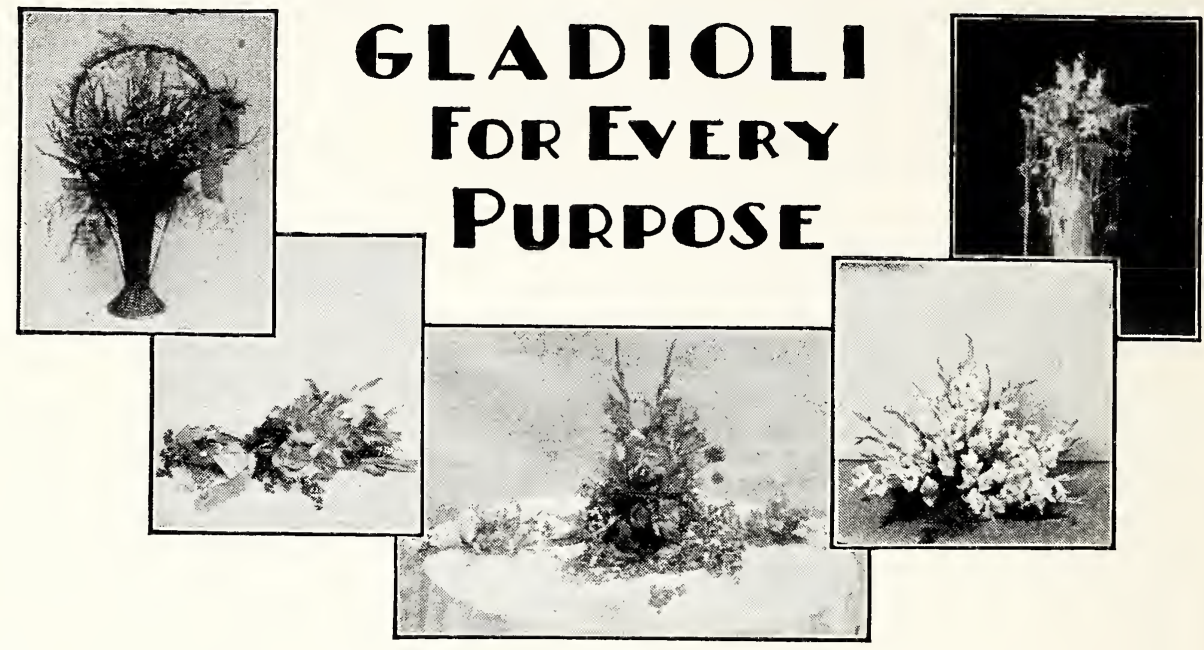

The great possibilities of the Gladiolus for cut flower purposes are now well known throughout the world. Today no other flower surpasses the Gladiolus in popular favor and esteem. This no doubt is mainly due to the fact that today the Gladiolus has a much greater variety of types and form than before the introduction of my new Ruffled and Laciniated types and the derivations from these and variations from them. Color variations in the earlier stages of Gladiolus development were quite limited, and as a result of these characistics, gladioli were mainly confined to garden planting. Little use was made of them and the magnificent floral displays we now know were unknown and not possible. Now, the situation is com. pletely changed; the Gladiolus stands boldly at the top of the list as one of the most adaptable and popular of all flowers, and its future stands unquestioned. The many changes, the glorification of new colors, the creation of new types, the variation in sizes and form and the lasting qualities all contributed to the inevitable popularity of this great flower.

There are so many uses for Gladioli that it has become generally known as the all-purpose flower. There are now thousands of beautiful varieties, in fact, I know of no other flower which is so diversified. For the sake of dividing the Gladiolus in groups most adaptable for floral decorations, I will name only the four most popular types in the order of their importance. The Ruffled Gladioli is the Kunderdii Type, the most outstanding Gladiolus of today. The edges of the petals of Kunderdii Type are intensely ruffled, much as in Azaleas and Spencer Sweet Peas. They are very artistic and beautiful for all manner of floral work and for landscape and garden planting and unsurpassed for decoration and show purposes. Artistic arrangements may be made up of a number of spikes of one color, or many varieties of varied colors. Gladioli used entirely alone make a magnificent appearance, but a few sprays of asparagus or fern leaf, or other decorative materials can be used to give certain desired effects. These gorgeous types are so beautiful and so impressive in them. selves that many are used as single spikes in bud vases. Gladioli are now used a great deal for funeral pieces, and various other designs.

Plain Petaled Gladioli (the term "Plain Petaled" is used to distinguish this group from the Ruffled Gladiolithe name does not mean to imply plainness) are another group of the large flowering types. In this group we find flowers with petals that are exquisite 
and graceful and also of varying sizes and form, and a wide range of beautiful color. The size of the flowers are about the same as in the Ruffled Type, and the range of color is almost unlim. ited. You will find in my catalog colors to suit your fancy and every require. ment. You will find them listed conveniently at unheard of prices and to meet every demand.

The next group, entirely different from the two preceding groups, is the Primulinus. Here is a flower that has gained popularity so rapidly that its rise to glory has been spectacular. Here is delicacy and refinement. Here is a group which embodies, as no other flower does, those marvelous pastel shades. But that is not all, Primulinus varieties are so artfully poised on their graceful slender stems that they fairly dance and smile at you. The little hooded upper petal and the butterfly. like wings give to them a most delight. ful appearance. This is a type that has made many new uses of the Gladiolus possible. Just a few years ago no one thought of using Gladioli in making up corsages, bride's bouquets and plateaus. Yet here they are at their best. A corsage made up from choice Primulinus varieties rivals in beauty the rarest of orchids. The same is true of other bou. quets. Elsewhere in this book is shown examples of these floral pieces, and I call your attention to the fact that the florets only were used with most striking effects. With this type a great many uses are possible, and here one has ample opportunity to show skill in ar. ranging many artistic effects. Your home can be made more pleasant and beautiful by the presence of these mag. nificent flowers, and your parties can be made more delightful occasions.

The fourth group is the Laciniated Gladiolus. This new race of Gladioli is still comparatively new, and, as the originator of this type or form, as well as of the Ruffled, I have had a number of years in which to watch its characteristics and the reception given it by the public, and I can safely say it is

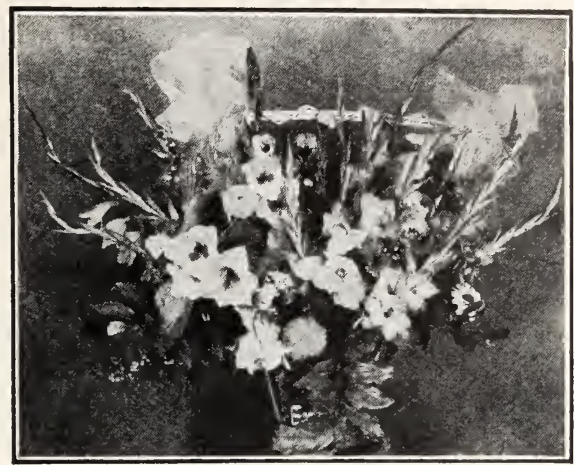

Gladioli Are Beautiful for Baskets

going to become one of the leaders in the Gladiolus world and add much new charm to the almost unlimited beauty and versatility of "The Modern Gladio. lus." The flowers are of a beautiful size with long curled or twisted petals as in Lilies, and the colors are as delicate as in the Primulinus class, and they are even more orchid or lily-like than the Primulinus. They grow on slender, graceful spikes and are still more "like butterflies." Their possibilities for floral work are limitless. Corsages, Bride's bouquets, Plateau Work, Vases, Baskets, Funeral Work are only a few of the ways in which Laciniated Gladioli can be used very effectively.

I regret I have no more varieties of this type to offer than I have at present, as these are quite a recent "new creation" of mine, and it takes a long time to work up a wide selection of beautiful colors in any new race for general dis tribution. However, I have many new and very beautiful varieties of this, my newest type, which will be in sufficient quantities to offer my patrons within a very few years. I feel every confidence in the future of this new race, and have no hesitancy in recommending them to my most discriminating patrons. I feel sure they will give you a pleasant surprise, and you will enjoy new thrills with your gladioli. 


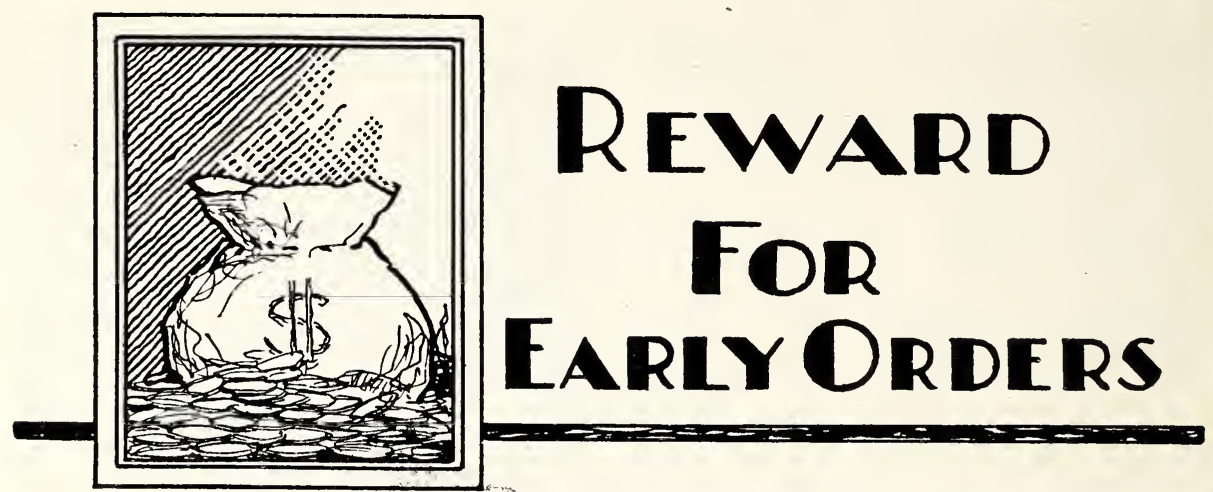

My prices average $60 \%$ lower than last year. This book is filled from cover to cover with bargains in Gladioli, such as you have never been offered before. Named varieties are listed to meet any color preference, and collections are listed in profusion to meet any need.

$\mathrm{IN}^{\mathrm{N}}$ addition to my greatly reduced 1 prices this year I am offering exceedingly liberal discounts in actual cash in consideration of early orders. Because I can handle your order so much more conveniently before the last minute rush I gladly make this liberal discount in cash.

At these price reductions it is now possible for everyone to enjoy a garden full of genuine Kunderd Gladioli. You will no longer have to be satisfied with substitutes for Kunderd Gladioli. These discounts, shown below, apply to individual orders as they are sent to me.
If you send me several orders within the time limit, to receive these benefits, each order must be figured separately on the basis of my offer. Orders coming at different times cannot be combined to receive the greater discount. If you should receive a second copy of this book or are not interested in the one $\mathrm{I}$ am sending you, I would be grateful if you will kindly hand it to a friend who is interested in the culture of beautiful flowers.

Kunderd Gladioli are the greatest value by far and now you can buy them at greatly reduced prices plus extra discounts, for simply sending in your order early.

\section{DISCOUNTS BELOW ALLOWED ON CASH ORDERS TO, AND INCLUDING FEBRUARY 20th, 1932}

\section{BEFORE ORDERING PLEASE READ NOTES ON PAGE 94}

$4 \%$ off on orders from ............... $\$ 2.00$ to $\$ 6.00$

$5 \%$ off on orders from............... 6.01 to $\mathbf{1 0 . 0 0}$

$\mathbf{6} \%$ off on orders from............. 10.01 to $\mathbf{1 5 . 0 0}$

$7 \%$ off on orders from.............. 15.01 to 25.00

$8 \%$ off on orders from............ 25.01 to $\mathbf{5 0 . 0 0}$

$10 \%$ off on orders from............. 50.01 to 100.00

$12 \%$ off on orders from................101.00 to 200.00

$15 \%$ off on orders from..............201.00 to 300.00

$18 \%$ off on orders from..............301.00 or more

Orders of $\$ 2.00$ and under are net, no cash discount will be allowed but if sent before February 20th, 1932, I will include one extra bulb of a choice named variety complimentary.

\section{SPECIAL NOTICE}

Above Discounts and Extras Apply Only on Retail Gladiolus Orders.

Orders for Seeds, Iris, Peonies, etc., Cannot Be Included in These Discounts. 


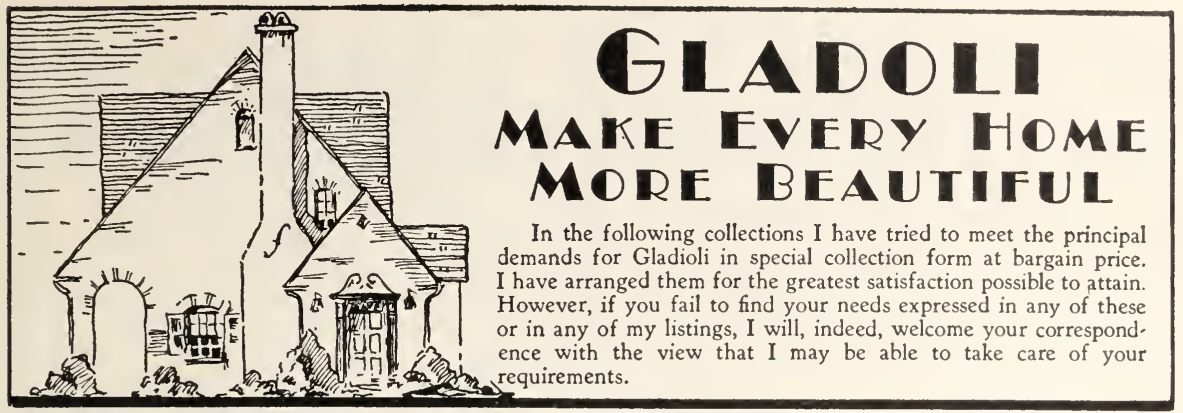

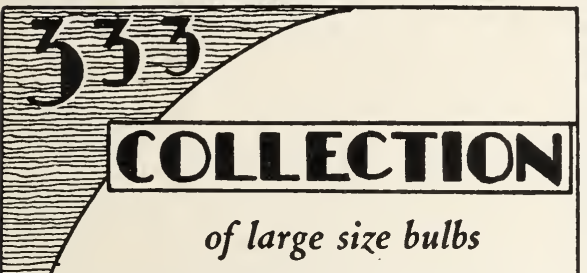

In my determination this year to meet all com. petition in Gladiolus offers excepting those of such inferior quality that no one with any knowledge of Gladioli at all would be satisfied, I offer you here a well blended collection of Gladioli in mixture, as to types and varying colors, that would have heretofore cost at least three times the price I ask. This collection consists of a magnificent array of varieties and one that would be a delight in the average garden. A hundred large, fine Gladioli of Kunderd quality to give you cheer during the summer time when flowers generally are least plentiful. No Primulinus Hybrids included.

\section{Bulbs, Only \$3.33 Prepaid}

50 Bulbs, Only 1.70 Prepaid 25 Bulbs, Only 1.00 Prepaid

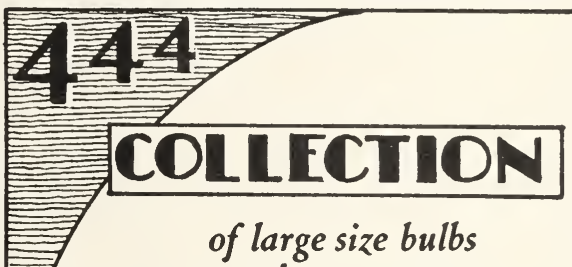

Mindful of the fact that my customers are to receive the most in Gladiolus bulb values this year than I have been able to give heretofore, and to meet the competition of present day prices, I have here a collection of Gladioli in mixed assortment comprising many varieties and a value that this same price would probably not bring to you from any other source. Here are red, white, lavender, etc., in profusion and at a cost of less than one-third what the same collection would have cost in the season of 1931 . Re member they are large, blooming size bulbs, and a well blended collection of Gladioli in mixture. No Primu. linus $\mathrm{Hy}$ brids included.

100 Bulbs, Only $\$ 4.44$ Prepaid 50 Bulbs, Only 2.25 Prepaid 25 Bulbs, Only 1.25 Prepaid

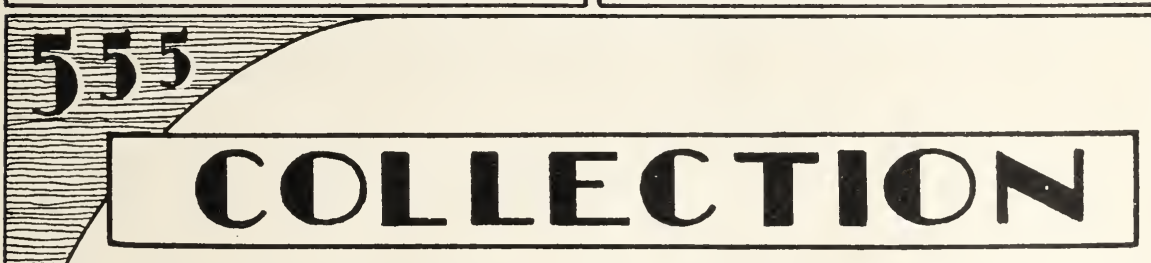

\section{of large size bulbs}

This attractive collection of choice Gladioli comprises many colors and the different types, is made up to in. clude the principal qualities of the two foregoing collec. tions, and to which will be added also some of the newer and more rare varieties including some of my world famous ruffled kinds. It is one that you will be very enthusiastic about, for the color harmony is simply wonderful. At blooming time you will be happy to find a range of colors from the most delicate tints to the deepest reds. A very extended list of varieties is put into this mixture and a hundred bulbs picked from the lot. It is sure to add cheer and beauty to your garden. No Primulinus Hybrids included.

$$
\begin{gathered}
100 \text { Bulbs, Only ... \$5.55 Prepaid } 50 \text { Bulbs, Only... \$2.80 Prepaid } \\
25 \text { Bulbs, Only ... } \$ 1.50 \text { Prepaid }
\end{gathered}
$$




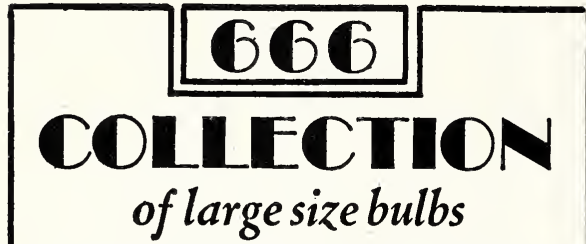

The glory of this collection is rather difficult to de. scribe in so many words of description. More ruffled kinds will be added; better plain petaled varieties in. cluded and in general a most choice assortment is offered. This collection contains a number of quite recent favorites and many varieties that have never been surpassed for beauty and type. The colors have been carefully chosen to make this collection easily one of my most outstanding bargains in Gladioli this season. I might suggest that if 100 bulbs of this choice mixture are purchased that they be planted at two different intervals, 50 as soon as garden making begins with the second lot of 50 to be planted 10 days or 2 weeks later. In this manner you extend the blooming date of Gladioli materially. No Primulinus Hybrids included. Priced at about one-third previous values.

100 Bulbs, Only $\$ 6.66$ Prepaid 50 Bulbs, Only 3.35 Prepaid 25 Bulbs, Only 1.85 Prepaid

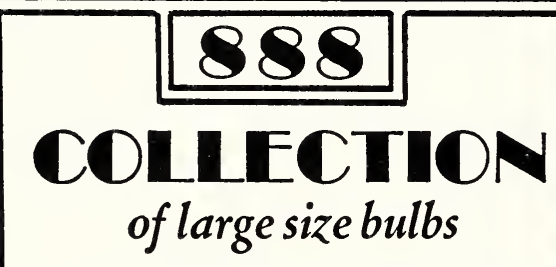

This Collection is of unusual quality through and through. No regular mixture of varieties will be included. Only named varieties from the many colors and types that I have to offer, and seedlings hereto: fore never offered, are contained in this' collection. It is a collection par excellence and one to delight the most ardent flower enthusiast. You will find at blooming time that varieties are included that have won premier honors from coast to coast and at international flower shows. Those who want the extraordinary in fine mixtures will find unusual satisfaction in collec. tion 888 .

\section{Bulbs, Only $\$ 8.88$ Prepaid}

50 Bulbs, Only 4.45 Prepaid 25 Bulbs, Only 2.50 Prepaid

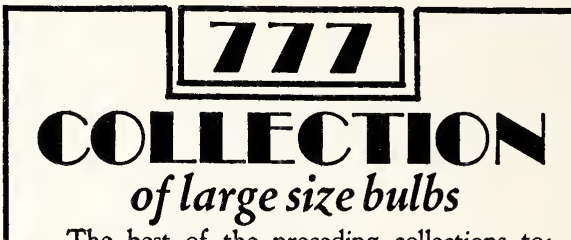

The best of the preceding collections to gether with many of my named varieties are used to comprise this unusual collection and big value in a choice mixture. The colors com. prise most of those existing in Gladioli, are of high Kunderd quality, entirely made up of large flowering varieties. With this mixture I mean to please and surprise even those who have grown Gladioli for years and are more fa. miliar with the fine things that are grown in this "king of the summer flowers." I am sure you will have unlimited praise for this collec. tion of highest quality, choice Gladioli includ. ing many fine named kinds. It is my intention to give you in these special collections a value of about three times what your money would have purchased but a year ago.

\section{Bulbs, Only $\$ 7.77$ Prepaid \\ 50 Bulbs, Only 3.90 Prepaid \\ 25 Bulbs, Only 2.15 Prepaid}

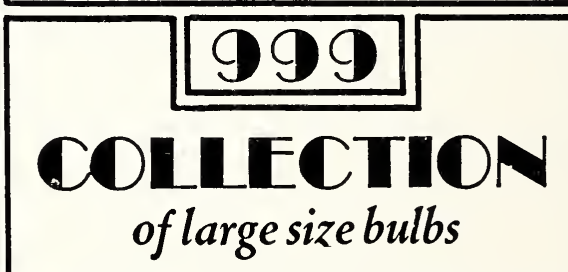

This collection of superior Gladioli is made up to meet the wishes of the most discriminating. More numbers of varieties are included and the more rare kinds than in any of the preceding collections. In the making up of these various collections more kinds have been con stantly added'as the price has been increased and newer and more rare varieties included. In this collection varieties will be found that have not as yet been introduced and some of my newer and high priced catalog kinds can also be seen, various laciniated varieties are among them. It is the last word in making up collec' tions of this kind and cannot be duplicated else' where in the world regardless of price. I offer it to you as a well blended assortment of Glad. ioli as to variety and superb quality.

\section{Bulbs, Only $\$ 9.99$ Prepaid 50 Bulbs, Only 5.00 Prepaid 25 Bulbs, Only 2.75 Prepaid}




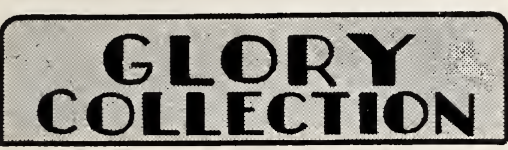

\section{It glorifies the American garden}

The above statement is a quotation from one of my testimonial letters received for this unusual collection of Gladioli in a mixture. Much might be said of it, as was of the Ideal Collection, excepting that a larger number of varieties have been included, more ruffled kinds and of the later things that have been produced. I would challenge any mixed assortment that any other grower could furnish with this mix. ture, regardless of price, and I offer here the unusual in Gladioli, all colors, but no primulinus hybrids included.

Many of the varieties here offered, if sold under name would cost several dollars, but grown in large quantity in a mixture, I am able to sell them at a price that would be impossible when kinds are grown separately. Though a named collection has certain desired advantages over being in mixtures, so the mixture has advantages over named varieties. When you have them in this type of collection though, you are assured of a fine range of color and very beautiful kinds. You have not definitely fixed your mind on a certain color to expect, and therefore, find it a delightful thrill to watch the new kinds unfold their beauty.

\section{Bulbs, Only $\$ 7.50$ Prepaid}

50 Bulbs, Only 3.95 Prepaid

25 Bulbs, Only 2.10 Prepaid

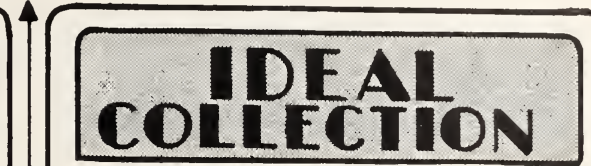

$A$ pageant of magnificent colors

As my many thousands, yes, hundreds of thou. sands of new seedlings bloom annually, among which are to be found great numbers of very beautiful kinds, and the most of which can never hope to find a market under name, I select thousands of fine va. rieties in every color and type to make up splendid mixtures.

This mixture is built over an ideal, as the name in. dicates, and is in reality, a pageant of magnificent colors. I should judge there are approximately 2,500 choice varieties in reds, from the very deepest to the brightest pinks, from intense rose shades to varieties of light blushed white shades, also whites, a few blues and lavenders and purples in profusion-in fact, quite a complete collection of Gladiolus colors and shades.

For many years I have offered this assortment to my customers, and millions of bulbs have been dis. tributed, and are to be found in gardens from coast to coast, as well as in foreign countries. It would re quire a book to publish the testimonials that I have received.

100 Bulbs, Only $\$ 5.50$ Prepaid 50 Bulbs, Only 2.30 Prepaid 25 Bulbs, Only 1.25 Prepaid

\section{WONDER COLLECTION}

\section{A crown of 10,000 jewels}

In this mixture, no doubt, there is growing a larger number of different choice Gladiolus varieties than in any other that is offered anywhere. Here I have growing together upwards of 10,000 varieties, selected with care from my seedlings to give to my customers the extraordinary.

The word "mixture" is oftentimes confusing to the buyer, as it is difficult with this word to justly describe the special collection of assorted Gladioli that I send out. It simply is to indicate that instead of bulbs coming to you separately and under name and label, they are sent altogether, without identification. The mixture is for those who do not care particularly for the record of the different varieties, and who do not have the time to grow them in this fashion, but want something choice for their gardens. Though hardly anything bad enough can be said of the average mixed collections offered on the market, it is difficult to exaggerate in words the unusual beauty of a really choice mixture. Mixtures with me have always been as much of an ideal as to offer my customers the best under name.

These bulbs are large size. They are quoted to you on the basis of present abnormal business conditions.
100 Bulbs, Only . . . \$9.95 Prepaid
50 Bulbs, Only.... \$5.50 Prepaid 25 Bulbs, Only. . . . \$2.85 Prepaid 


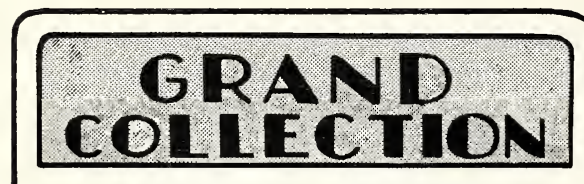

As life-like as Butterflies

This assortment consists entirely of primu. linus hybrids, both of the primulinus species type and those of the more improved or more primulinus-grandiflora type. The latter are in greater profusion, as I am constantly improv. ing my mixtures and am more exacting as to the choiceness of the kinds that are permitted to be included.

Though they run primarily to yellows and orange shades, there are also those of all other shades to be found in Gladioli. These come in the plain petaled and ruffled varieties in the dainty little fellows to very large ones, also. The primulinus as a class contain many qualities that the other types do not possess. Practically all of the pastel shades are to be found in this type, and for use in floral decorations of many kinds they far outclass other varieties. No gar. den should be without a liberal planting of these fine Gladioli

\section{Bulbs, Only $\$ 5.00$ Prepaid 50 Bulbs, Only 2.75 Prepaid 25 Bulbs, Only 1.45 Prepaid}

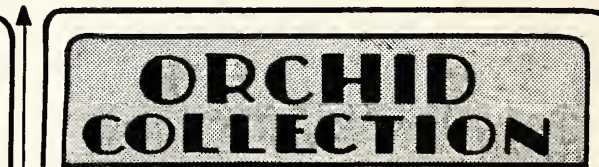

\section{As beautiful as Orchids}

This splendid mixed assortment of fine primulinus hybrids constitutes the latest of my selection in choice primulınus and grandiflora primulinus varieties, the best obtainable. There are among the lavenders, shades that rival the orchid, yellows from faint sul. phur to almost buttercup, creams and delicate pinks in large numbers. Though the primulinus class runs primarily to light and delicate shades, they also in. clude all other colors, however, in lesser number.

For decorative purposes the primulinus varieties are unequaled. For daintiness and refinement there are no other Gladioli to equal their charm. They can be used on many more occasions with greater effec. tiveness than the larger and more vivid colored kinds. I say, without hesitancy, that they rival the orchid. In fact, it is this type that is of ten referred to as the orchid type of Gladioli.

You can buy this extraordinary collection with complete confidence of satisfaction, as thousands of other customers have before. Priced to meet the popular trend in business conditions.

100 Bulbs, Only $\$ 7.95$ Prepaid 50 Bulbs, Only 4.15 Prepaid 25 Bulbs, Only 2.25 Prepaid

\section{TRIUMPH COLLECTION}

\section{of large size bulbs}

This collection, no doubt, will come to many of my customers às a complete surprise and something quite extraordinary. Briefly, it may be described as a complete assortment of the named Gladiol contaned in my catalog as of 1931. No varieties, regardless of price, have been omitted and every type known to my named Gladiolus collection is included. To best comprehend the worth of this collection it might be well to glance through my catalog varieties noting carefully the prices and descriptions and the excellence of both the newer and older Kunderd Gladioli. Imagine a collection made up of every one of these magnificent Gladiolus creations and you will realize the merit of this special collection. This is the collection for those who want the best to be had in the way of quality without any special desire to have them under name.

$$
\begin{aligned}
& 100 \text { Bulbs, Only........\$17.50 Prepaid } \\
& 50 \text { Bulbs, Only......... 8.70 Prepaid } \\
& 25 \text { Bulbs, Only.......... 4.50 Prepaid }
\end{aligned}
$$




\section{WHITE \\ Special all white \\ and \\ blushed white varieties \\ There are many Gladiolus enthusiasts who have decided color preferences and for them I am offering four special collections in color classes. This collection consists of all white varieties and those which are blushed with cream, faintly tinted pink, peach or other very dainty shades. Those who wish the lightest and daintiest shades in Gladioli will find this assortment very pleasing. These are all large size bulbs of highest quality in a mixture and are priced very moderately.}

\section{Bulbs, Only $\$ 8.85$ Prepaid}

\section{Bulbs, Only 4.45 Prepaid 25 Bulbs, Only 2.50 Prepaid}

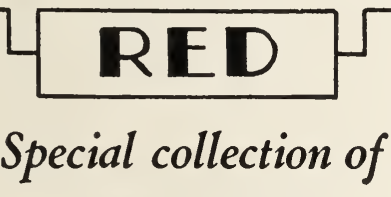
red Gladioli

\section{(ALL SHADES)}

For those who prefer the bolder, richer colors, will find this collection superbly beautiful. It contains colors from the deepest mahogany reds to rich golden oranges and flaming carmine reds. It is a collection of Gladioli which I find is greatly admired, and is bound to appeal to every one who loves rich colors. These bulbs are of finest quality, large size in a mixture.

\section{Bulbs, Only \$8.85 Prepaid} 50 Bulbs, Only 4.45 Prepaid 25 Bulbs, Only 2.50 Prepaid

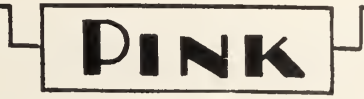

\section{Special collection of}

\section{pink Gladioli}

\section{(ALL SHADES)}

This collection consists of choice varieties varying from light pinks to almost whites, some of delicate peach color, to the darkest shades of pink. It is a magnificent collection for those whose choice is pink, as it embodies the various shades of pink from lightest to darkest and is sure to please those who have a preference for this color and these shades. These are all large size bulbs of high quality in a mixture.

100 Bulbs, Only $\$ 8.85$ Prepaid 50 Bulbs, Only 4.45 Prepaid 25 Bulbs, Only 2.50 Prepaid

\section{YEILOW
Special collection of yellow Gladioli}

\section{(ALL SHADES)}

In this collection are the yellow, buff and cream kinds and of such beauty that will thrill the lover of choice yellow flowers. They will prove a marvel in your garden. The yellow varieties seem to have a definite place in every garden and there is hardly a color that lends itself to so many varied conditions. Yellow harmonizes beautifully with many other colors and for this reason is always a favorite. It is, indeed, a color of the summer time. Only highest quality bulbs of large size in a mixture are furnished.

100 Bulbs, Only $\$ 8.85$ Prepaid 50 Bulbs, Only 4.45 Prepaid 25 Bulbs, Only 2.50 Prepaid 


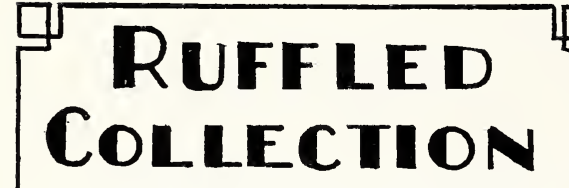

This collection comes after repeated suggestions and requests from my customers who desire an all ruffled collection of Gladioli in mixture. This is the first year, however, I have been able to make up such a collection and include all colors and shades in such proportions as would be sufficiently pleasing to meet my ideal and standard. This collection con sists of nothing but ruffled kinds, in all colors, and remember it is the origination that has made the name of Kunderd internationally famous. This mix. ture is priced exceedingly low.

100 Bulbs, Only $\$ 9.50$ Prepaid . 50 Bulbs, Only 4.75 Prepaid 25 Bulbs, Only 2.50 Prepaid

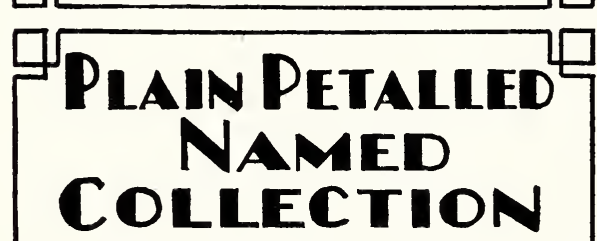

The plain petaled Gladioli are really gorgeous in the truest sense of the word, and in the possession of a goodly number of these only is it possible to get wide variety of choice things that would not other. wise be obtainable.

Many persons who wish a collection of choice Gladioli find it difficult to order from the extensive lists I offer, and it is for those that are willing to take my suggestions and recommendations that $I$ offer this collection. I will send you twenty-three varieties, one bulb each, properly labeled and constituting a wide variety of colors and shades for the small sum of but

\section{它}

$\$ 1.70$ Prepaid

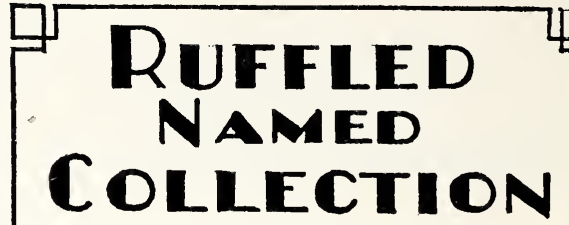

I will make up for you an assortment of nineteen ruffled gladiolus varieties, one bulb each in all colors, properly labeled for identif. cation, for the small sum of $\$ 1.65$. This service is to facilitate the ordering of a choice ruffled collection at a minimum cost, and I assure you that nowhere else would you find such a splendid assortment of all ruffled varieties under name for so little money.

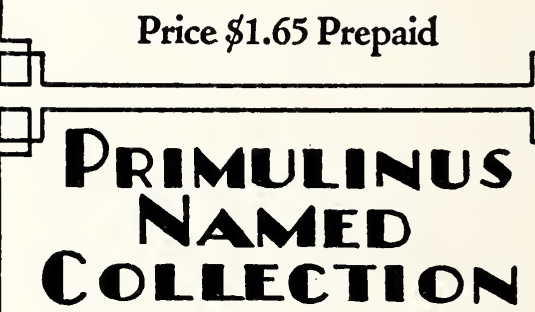

In many respects, the Primulinus Hybrids are my favorites of all Gladioli. They come in the daintiest of pastel shades and lend themselves more beauti fully to finer decorations and floral work than do many of the other so called large flowered Gladioli. While some of them remain smaller than the aver. age of the other groups, there are many, too, that have reached large proportions-most equal to the largest grown. This group of Gladioli constitutes the most delicately beautiful and refined of all Gladioli. You should have this collection in your garden, by all mèans.

I offer a choice selection of 17 varieties, one bulb each, properly labeled, sent to you for only

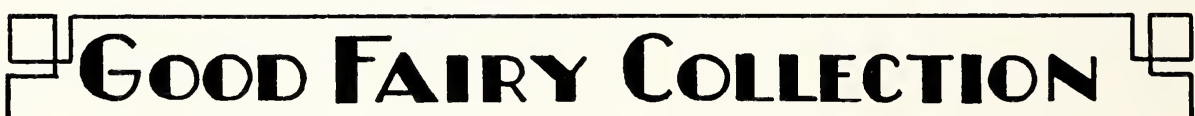

\section{Ruffled, plain petaled and primulinus varieties combined, all named varieties, labeled}

Now, here comes your opportunity to have a really large collection of Gladioli, comprising my most famous ruffled varieties, the gorgeous plain petaled kinds and the dainty primulinus hybrids, really a quite complete collection, and sent to you in about like proportions of types. Many colors and shades are included.

I offer you my selection of 49 distinctly different Gladiolus varieties, one bulb each, large sized stock, too, properly labeled for identification, and shipped to you for the small sum of

\section{$\$ 4.85$ Prepaid}




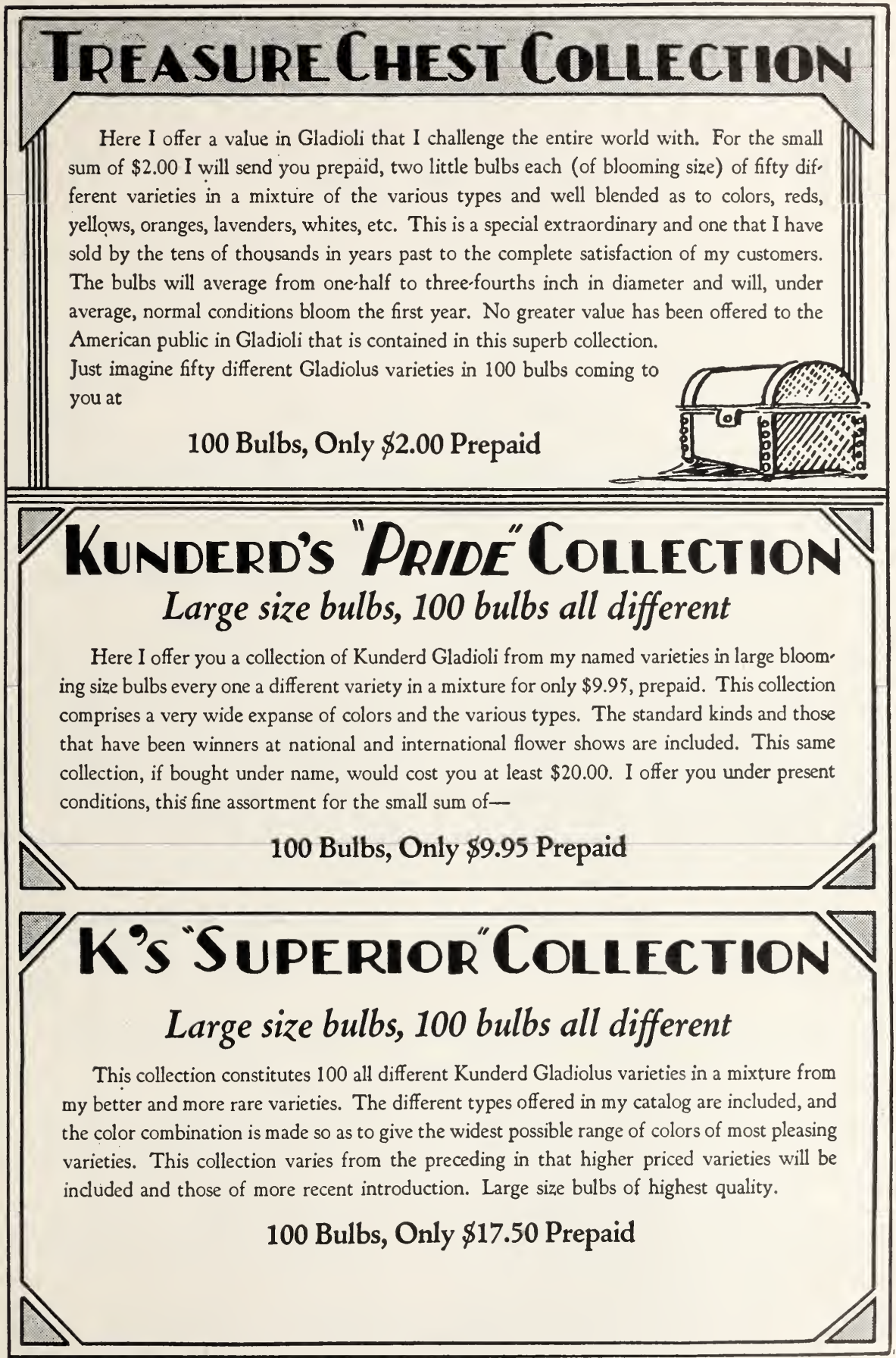




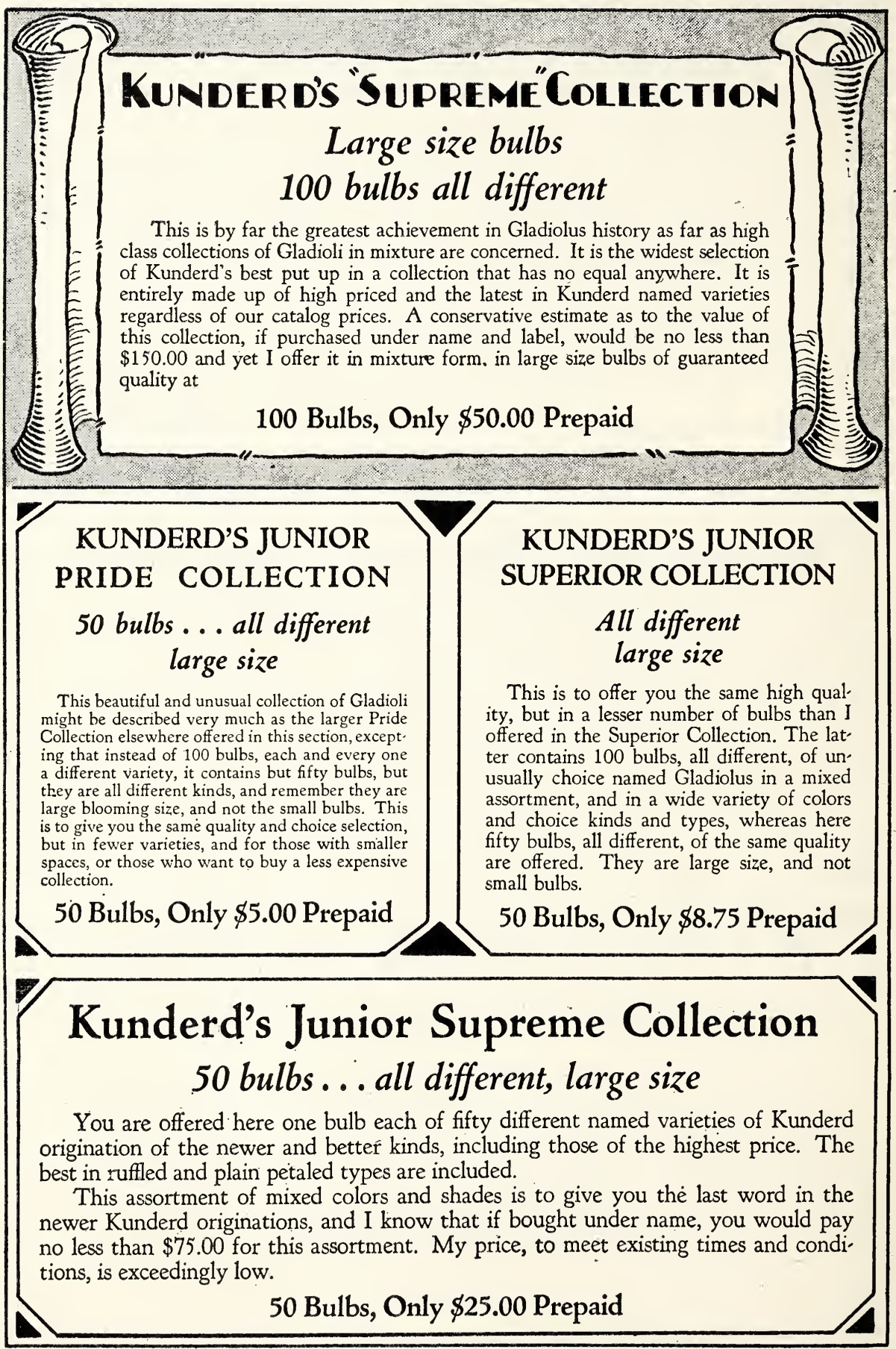

Take Advantage of My Discounts for Early Orders. See Page 8 


\section{Neru Gladioli for 1932}

In the following list of new Gladioli, brought to your attention for the first time, I offer the latest creations in Gladioli. These are the best of the new varieties which have appeared on my trial grounds the past season. I present these with confidence as to their future popularity.

Chas. A. Stevens (1932-Plain Petaled) -A tall; stately plant. Large flowers of finest soft rose pink, lighter in the throat. A very refined and refreshing color, beautiful for all purposes. Each, $\$ 1.00$. Doz., $\$ 10.00$.

Chum (1932-Plain Petaled)-A tall plant with very large flowers nicely placed, all facing one way. Ground color deep old rose, slightly flaked deeper. Throat light rose red with beautifully feathered central bars. An unusually showy and distinct flower in this class. A fine garden variety. Each, 75c. Doz., \$7.50.

Consolation (1932-Plain Petaled)-A tall, showy plant with many large beautiful flowers open at a time. Color, a deep violet self with blotches of a deeper red on lower petals and a dark red midrib or median line extending each way, terminated by a small white central line extending towards the tips of the petals. First Class. Each, $\$ 1.00$. Doz., \$10.00.

Contentment (1932-Ruffled)-An extra tall and stately plant, flowers of purest white with faintest blush over all the petals. Lower central petals beautifully feathered; a delicate rose pink. A distinct and lovely new ruffled variety. Each, \$1.00. Doz., \$10.00.

Coronet (1932-Plain Petaled)-A tall fine plant with large flowers. Color, a smoky copper tone with deeper red on lower petals and lighter faded shade on outer ends of the petals. Lower petals have narrow, clear white midrib or central lines, making in all a very distinct and unusual variety. A fancy show flower for the garden. Each, \$1.00. Doz., \$10.00.

Dusky (1932-Plain Petaled) - A tall, fine plant with many good sized flowers open at a time. Color, clearest deep salmon red; a little deeper over the back of the petals, and a dark feather or median line on the lower ones. A very fine showy garden flower. A fine cut flower. Each, \$1.00. Doz., \$10.00.

Embers (1932-Ruffled)-A tall, stately plant and large flowers of richest orange vermilion, with deep orange red throat, beautifully blended with the ground color. A very pretty bar of subdued white extends beyond the throat blotches towards the lower petal tips. An exceedingly rich and showy flower. Among the very best. Each, \$2.00. Doz., \$20.00.

Eulah (1932-Plain Petaled) - A tall, fine plant with plenty of good sized flowers open at a time. Color over all petals a very beautiful deep coral salmon pink, or light coral red. All petals have a narrow line of white, and the lower petals have a large pure white throat. A very fine flower with all the colors blended in a most harmonious manner. Suitable for all purposes. Each, \$1.00. Doz., \$10.00.

Golden Copper (1932-Primulinus $\mathrm{Hy}$ brid) - A good height plant with ample medium to large sized flowers, for this class, open at a time. Color over all the petals a coppery gold and sometimes flaked a little deeper on the outer edges of the petals. Throat on lower petals a soft, delicate daffodil yellow feathered with orange central bars. A very distinct and showy primulinus variety, and the name describes its color. Each, 50c. Doz., \$5.00.

A very attractive Basket of Gladiolus, combined with Asparagus Fcrn and ticd with an effective ribbon. This is a basket arrangement which can be made by anyone not having previous experience.

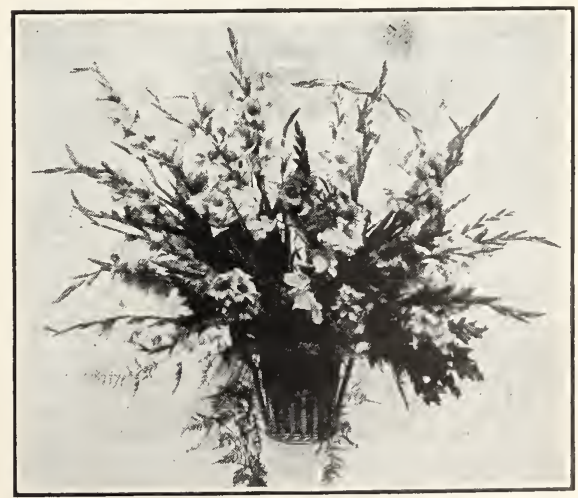




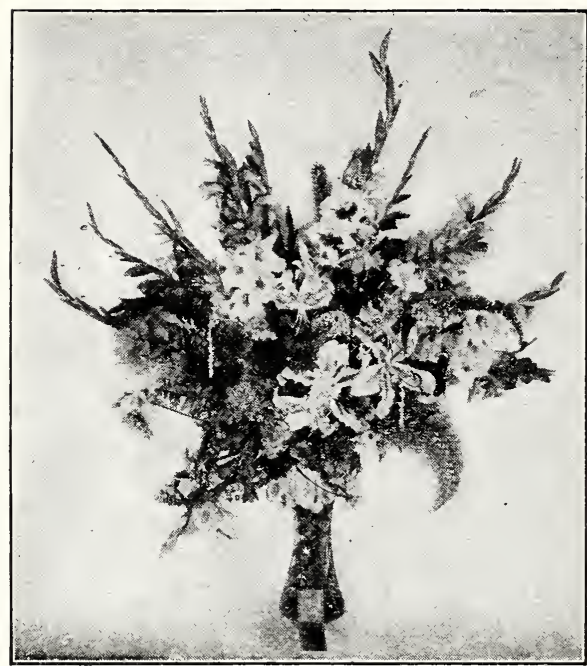

A beautiful vase of Gladioli, Rubrum Lilies and Asparagus Fern. This is a combination that is very beautiful and suitable for either formal or informal occasions.

Golden Slippers (1932-Ruffled)-A tall, fine graceful plant with five or more exceedingly beautiful flowers open at a time. Color, upper portion deep salmon, or shrimp pink with softest golden tint. Lower petals of same color toward the ends, but have a throat marking of soft daffodil yellow, beautifully feathered with narrow lines of a light rose pink. One of the most beautiful new ruffled varieties and suitable for all purposes. Each, $\$ 2.00$. Doz., $\$ 20.00$.

Greetings (1932 - Ruffled) - A tall, stately plant with large and very showy flowers of deep salmon rose color, a little lighter in the throat and beautifully penciled or feathered rose pink central lines. An exceptionally fine new ruffled variety. First class. Each, \$2.00. Doz, \$20.00.

Helen M. (1932-Plain Petaled)-A tall, fine plant with six to eight good sized flowers open at a time. Color a delicate La France pink, deepening towards the outer ends of the petals, which are sometimes lightly flaked deeper. Throat deeper creamy yellow with narrow pencil lines towards the base. This will become a first class florist's flower, as the delicate and refined coloring equals the best varieties. Each, $\$ 1.00$. Doz., $\$ 10.00$.

Hummer (1932-Ruffled)-A tall, fine plant with many good sized flowers open at a time. Main color a dark velvety red with brighter red on lower petals. A very narrow pure white cen- tral line on the lower petals aids in giving the flower a very striking appearance. Outer edges of all the petals of deep, dark red, flaked deeper. An unusually distinct and showy new ruffled variety. Lightly ruffled. Each, 50c. Doz., \$5.00.

Lady Pink (1932-Plain Petaled)-A quite tall and stately plant with six or more large flowers open at a time. Color a fine deep rose pink of very deep peach blossom color. Large and beautiful blotches on lower petals with narrow white central lines. A first class pink, and suitable for every purpose. Each, \$1.00. Doz., \$10.00.

Laughter (1932-Plain Petaled)-A tall, showy plant with large widely expanded flowers; color a fine tone of flesh with soft tints of blushed yellow in throat and fine rosy purple median lines, beautifully feathered at either edge. Each, \$2.00. Doz., \$20.00.

Lohengrin (1932 - Plain Petaled)-A quite tall and showy plant with six or more large and beautifully placed flowers open at a time. Color, finest deep flesh pink with beautiful light rose feathered blotch in throat. One of the most attractive and beautiful florist's varieties, which will no doubt become popular for this purpose, as well as for general planting. Each, 75c. Doz., $\$ 7.50$.

Lyric (1932 - Primulinus Hybrid - A tall, fine plant with six or more large well expanded flowers facing perfectly one way. Color, deep orange red; a little deeper towards the edges of the petals and a deeper red in the throat with still darker midrib or median lines. A very fine grandiflora primulinus variety. Each, 50c. Doz., \$5.00.

Marilyn (1932-Plain Petaled)-A tall plant and large flowers, well expanded and all facing one way. Color a delicate lavender rose, blushed on a white ground. Throat creamy white with soft yellow central bar or midrib. The several color shades all delicately blended into a very harmoniously colored and beautiful flower. Each, \$1.00. Doz., $\$ 10.00$.

Mary Ann (1932-Plain Petaled)-A fine height plant with many fair sized flowers open at a time. Blooms of a delicate faintest blush white and many open at a time, closely, but perfectly placed on the stem. A very elegant and artistic cut flower, no doubt first class for florist's use. Each, $\$ 1.00$. Doz., $\$ 10.00$.

Mirage (1932-Plain Petaled)-A tall, stately plant and very showy flower. Large widely expanded blooms, petals beautifully recurved. Color, deep, 
salmon rose with throat still deeper and fine bluish median lines. A very showy and beautiful flower for the garden, or as a cut flower. Each, $\$ 1.00$. Doz., $\$ 10.00$.

Miss Muskegon (1932-Plain Petaled) Quite a tall fine plant with five to seven large flowers, beautifully placed, open at a time. Color a rich Begonia rose, sometimes flaked a little deeper towards the edges of the petals. Lower petal has a darker red tone towards the base with a beautifully feathered bluish median line extending half the length of the lower three petals. A very distinct color, and one of the most beautiful varieties and sure to become popular. Each, $\$ 1.00$. Doz., $\$ 10.00$.

Mystery (1932-Plain Petaled)-A tall, graceful, slender plant with six or nore flowers open at a time. Color, deep dark purple, flaked deeper and much deeper color on lower petals. A showy garden and cut flower variety. Each, 50c. Doz., $\$ 5.00$.

Paula (1932-Ruffled) - A tall, fine showy plant with six or more large beautifully placed flowers open at a time. Color, deep rose pink, or light bright rose red. Deeper on lower petals with still darker median lines. A large flowered, beautiful and showy, very attractive. Each, $\$ 1.00$. Doz., $\$ 10.00$.

Pink Witch (1932-Plain Petaled)-A tall, strong and showy plant with six to eight or more large soft rose pink flowers open at a time. Outer portion of petals delicately flaked a little deeper pink, and throat marked with a very fine soft tone of creamy yellow. Deeper yellow median lines. A very delicately colored flower with very beautiful tints, and a first class showy cut flower variety. Each, \$1.00. Doz., \$10.00.

Renata (1932-Plain Petaled)-A fine good height plant with large flowers placed on a perfect stem, and all facing perfectly. Six to eight flowers open when in good condition. Color a deep orange scarlet with very beautiful throat of a soft lemon or sulphur shade, and with deeper yellow central bars. Perhaps the finest of this color in the list. A beautiful garden flower, also suitable for cut flower purposes. Each, $\$ 1.00$. Doz., $\$ 10.00$.

Roscoe Huff (1932-Ruffled)-A tall, graceful slender plant with good sized flowers. Beautifully ruffled and petals pointed and recurved like in a lily. Color of the upper. portion of the flower is a deep cream with light rose pink overcast and lower petals of a soft daffodil yellow with very slight pink median feathered lines. An exceedingly rich and showy ruffled variety. Each, $\$ 3.00$. Doz., $\$ 30.00$.
Seaside (1932-Plain Petaled)-A fine height and shapely plant with many medium sized flowers open at a time. Color of a daintiest pure soft rose pink over all the petals and a creamy yellow throat with deeper yellow midrib or central lines. An exceedingly refined and elegant flower on elegant plant and very daintily placed. There is hardly a finer pink in any shade. Each, $\$ \mathbf{2 . 0 0}$. Doz., $\$ 20.00$.

Sky-Line (1932-Plain Petaled)-A very tall and stately plant with very large widely expanded flowers and petals well recurved. Color, soft pure white, tinted rose pink with beautiful feathered median lines on lower petals on soft, creamy white ground. A first class flower in every way, showy and beautiful. Each, $\$ 2.00$. Doz., $\$ 20.00$.

Swan (1932-Plain Petaled)-A fine height plant and medium sized flowers, beautifully placed on the spike. Six to eight or more blooms open at a time. Color, softest white with creamy tones in throat. Soft delicately blushed towards the base on back of the flowers. One of the most delicate and refined white Gladiolus for florist's use, and equally good for bedding and cut flowers. A rapid multiplier. Each, $\$ 1.00$. Doz., $\$ 10.00$.

Thought (1932-Plain Petaled)-A fine height plant and good sized flowers with three to five blooms open at a time. Deep rose pink over-all the petals, excepting an exceedingly large and almost black blotch on the lower ones. A very fancy show flower and unusual. Each, $\$ 1.00$. Doz., $\$ 10.00$.

Vagabond (1932-Plain Petaled)-A tall, stately plant with many very large flowers open at a time. Color, a lovely rose pink with blotches on lower petals a fine deep rose red and deeper median lines. A distinct, showy and first class flower. Each, \$2.00. Doz., \$20.00.

Yukon (1932-Ruffled) - A good height plant with large and finely ruffled petals. Color a delicate pure white. The flowers on this variety are irregularly, but gracefully placed, and the plant makes an unusually showy and attractive appearance. The quality of this variety is as attractive as any white, and the plants are all as upright as a pillar and make a very showy appearance in mass. A good multiplier and stock in good supply, hence, a very low price. Each, 50c. Doz., \$5.00.

James B. Maple, Pres., Indiana Gladiolus Society, Sherman Bldg., Sullivan, Ind. July 17, 1931. Due to the fact that we are going to have many out of state visitors we are especially urging our home growers to put their best foot forward in the display of their wares, and as you folks are, without question, the head and shoulders of the industry I am asking you to do the best you can for us in the way of display this year. 


\section{Collection Offers of \\ New Kunderd Gladioli \\ These Collections Are All Sent with Each \\ Variety Properly Labelled}

Collection No. 1-All varieties valued at $50 \mathrm{c}, 5 \mathrm{bulbs}$ in all (value $\$ 2.50$ ) for.............. \$2.25

Collection No. 2-All varieties valued up to and including 75c, 7 bulbs in all (value $\$ 4.00$ ) for.......\$3.60

Collection.No. 3-Your selection of any 6 of the $\$ 1.00$ varieties (value $\$ 6.00)$ for.............\$5.40

Collection No. 4-Your selection of any 12 of the $\$ 1.00$ varieties (value $\$ 12.00)$ for............\$10.80

Collection No. 5-All varieties valued at $\$ 1.00,17$ bulbs in all (value $\$ 17.00$ ) for.............\$15.30

Collection No. 6-All varieties valued up to and including $\$ 1.00$, 24 bulbs in all (value $\$ 21.00$ ) for..... $\$ 17.85$

Collection No. 7-All varieties valued up to and including $\$ 2.00$, 31 bulbs in all (value $\$ 35.00$ ) for ..... \$29.75

Collection No. 8-Entire collection, one each of the 32 varieties listed (value $\$ 38.00$ ) for..........\$32.30

\section{VARIETIES CONTAINED IN THESE COLLECTIONS ARE FOUND IN PAGES 17 TO 19}

F. W. Todd, New Jersey. July 9, 1931. The first blooms from some Glad bulbs purchased from you this Spring are just coming out.

Have been raising flowers in a small way for the past five or six years, but I have never been wonderful; spikes wonderful as the ones I'm now getting from your bulbs. You can count on me being one of your biggest boosters.

Abram L. Snyder, New

York. Aug. 15, 1931. I thought you would like to hear from the Glad bulbs I ordered from you. They have been wonderful; spikes over $5 \mathrm{ft}$. 10 in. high and 20 to 21 buds on them. Some of the blooms measured 5 to 6 inches across. I planted them 3 ft. wide and 4 inches in rows, staked and wired and lots of cultivation.

Your bulbs are all you recornmend them to be.

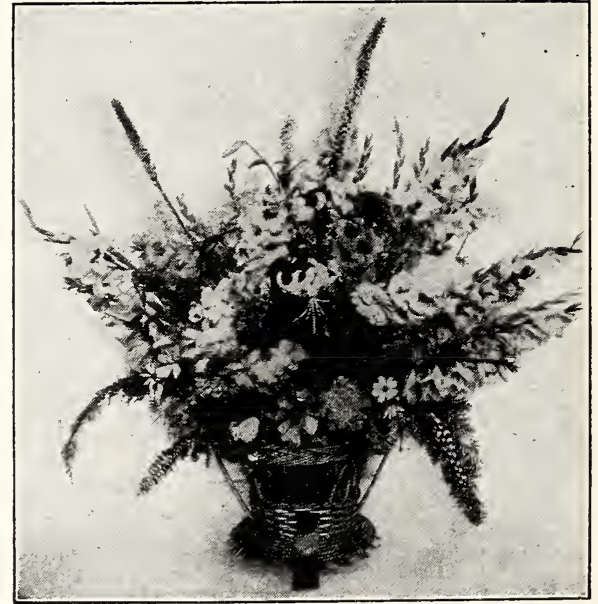

Gladioli in mixed bouquet are very striking. Here is shown Gladioli with Liatris and Rubrum Lily with fern and wild flowers interspersed.
Mrs. R. E. Peckham, Indiana. Feb. 28, 1931.

While I'm writing you I think it might interest you to know that last summer (my first year as a gardener) I ordered Glads from four different growers, and yours were by far the best. Yours were in every instance larger blooms and of a fancier quality. When dug this Fall the Kunderd bulbs had also produced much larger corms than any of the others.

So, I'm sold on Kunderd quality, and from now on I hope to be able to buy some Glads from you every year until I have a collection I'll be proud of.

Carl T. Mack, D. C.

Everything I have ordered from you grows to beat the mischief. 


\section{Popular Ruffed Gladioli, Kunderdii Type}

This list comprises many varieties of the famous Ruffled Gladioli, the first new type of this flower to have ever been produced in America, and the type which probably brought about greater influence than any other factor in the extraordinary popularity which the Gladiolus enjoys today.

These ruffled beauties come in any color to suit your preference, and a very desirable collection is obtainable at a very modest sum.

Achievement (1931)-Fine height and vigorous, strong plant with giant widely expanded flowers. Five or more open at a time, intensely ruffled. Color of rich deep canary yellow with very large beautiful red blotches on lower petals. A magnificent and showy variety to be classed among the very best. Each, $\$ 10.00$. Doz., $\$ 100.00$.

Alton (1917. 80 days.)-A wonderfully ruffled variety of finest orange color. A magnificent gladiolus. Winner of many awards. Each, 12c. Doz., \$1.20. $100, \$ 9.00$.

Anthony B. Kunderd (1918. 86 days.)Tall, large, intensely ruffled flower of delicate, deep cream color. Overspread finest blush pink. Entire lower petals beautiful primrose-cream flushed pink at edges. Grand. Winner of many awards. Each, 12c. Doz., \$1.20. 100, $\$ 9.00$.

Antione (1928. 67 days.)-Fine, upright plant. Flowers intermediate in type between large flowered and Primulinus. Color no doubt the richest deep yellow to be found in any gladiolus. A true, rich, deep, pure chrome yellow over entire flower and a pure self. A wonderful, very deep, pure spectrum yellow and first class in every way. Each, 50c. Doz., \$5.00.

Arcturus (1928. 66 days.)-A good strong plant and good sized flowers of deep, rich sulphur yellow. Upper and lower petals a deep or golden canary yellow with blotches of red and deeper dark central bars. Each, 25c. Doz., \$2.50. 100, \$18.75.

Avalon (1916. 71 days.)-An extra choice blush white with very beautiful red throat markings. A magnificent flower. Illustrated on page 49. Each, 10c, Doz., $\$ 1.00$. 100, $\$ 7.50$.

Beauty Wave (1927. 83 days.)-Rich shade of canary-yellow. Deeper on lower petals with finely feathered central bars. A sturdy, graceful plant.
Flowers well ruffled. Each, 25c. Doz., $\$ 2.50$. $100, \$ 18.75$.

Blanche Bollinger (1925. 72 days.)-A pleasing and showy flower. Many large, medium ruffled flowers open at a time. A very distinct and pleasing shade of old-rose pink. Each, 12c. Doz., $\$ 1.20$. 100, $\$ 9.00$.

Blushing Beauty (1922. 88 days.)Opening buds blush pink, flower softest possible blush, many open. Dainty pink throat lines. Plant of good height. A marvel of daintiness and refinement. Each, 12c. Doz., $\$ 1.20$. 100, $\$ 9.00$.

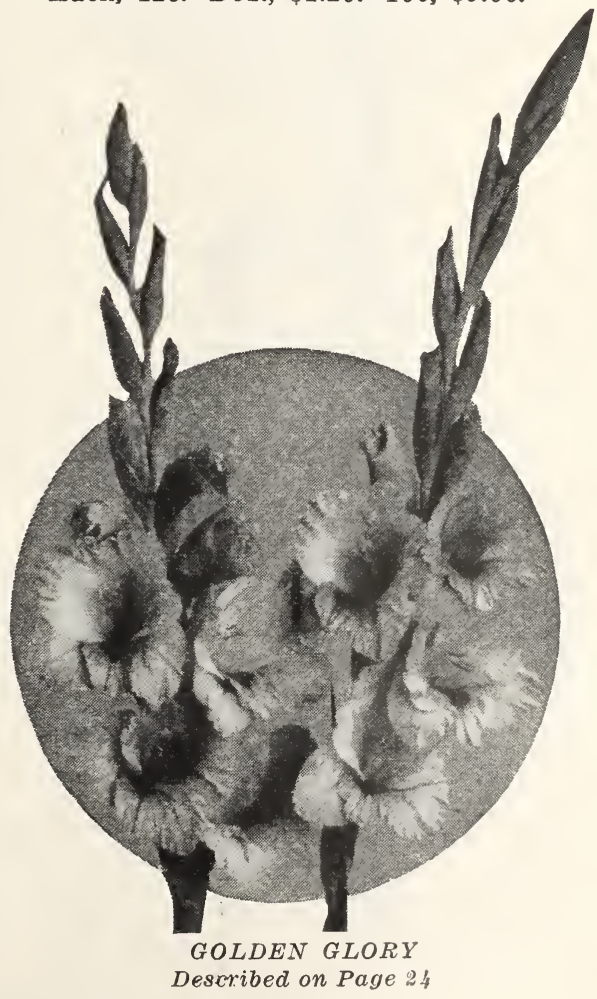


Bridal Rose (1928. 83 days.)-Large, showy plant with large flowers of a rich rose pink. Lower petals have very beautifully red penciled throat on a delicate, creamy yellow ground. Central or median lined a refined deep red, veined and traced in beautiful, slight thread lines of same color. Each, 25c. Doz., \$2.50. 100, \$18.75.

Brown Lily (1930. 64 days.) - Tall plant with large flowers, petals, curled, twisted and pointed in finest lily fashion. Prettily feathered red throat blotches on a beautiful soft creamy ground. An unusual and attractive garden variety. Each, 50c. Doz., $\$ \mathbf{5 . 0 0}$.

Buckeye (1921. 78 days.)-Very large, massive bloom of fine rose-pink color with tint of old-rose at edge of petals. A beautiful, large rose-red throat. Very good. Each, 10c. Doz., $\$ 1.00$. 100, $\$ 7.50$.

Canary Feather (1930. 80 days.)-Nice height, graceful slender plant with large nicely shaped and perfectly placed flowers. Color of upper petals and ends of lower petals a delicate canary yellow. Lower petals much

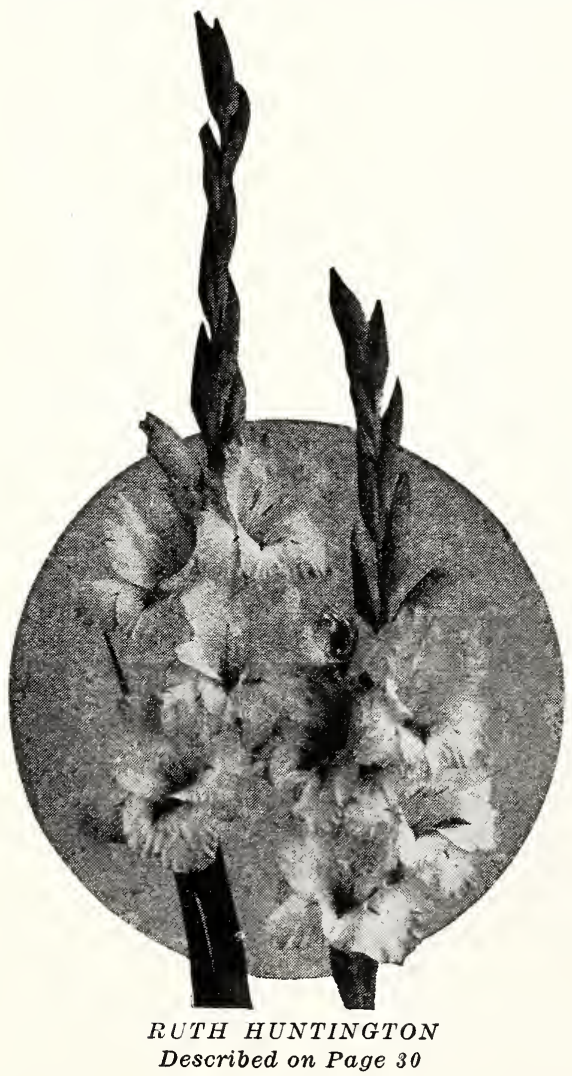

deeper rich canary or medium daffodil yellow, slightly penciled soft pink towards the base of the throat. A very elegant and refined yellow. Each, 35c. Doz., \$3.50. 100, \$26.25.

Cattleya Rose (1928. 70 days.)-Fine height of spike and stately plant. Large flower of beautiful cattleya rose color and exquisite form. Lower petals of a dainty pastel yellow color onehalf way and outer one-third of petals of same color as upper petals. Central part of lower petals have neat median line of deep maroon or wine red, traced and feathered at sides with same color. A very orchid-like and beautiful variety. Each 50c. Doz., \$5.00.

Chalice Flower (1924. 74 days.)-A tall, beautiful plant with a very refined and elegant flower. Flowers large and plenty open at a time. Cup of roundish form, suggestive of its name. Color of light, creamy blush white of pleasing effect. Very artistic and beautiful. This variety won A. G. S. Trophy, 1926, for best funeral spray of white gladioli. It also won two other First Prizes for best funeral spray of white gladioli. hibited at the same show. Illustrated on inside back cover. Each, 15c. Doz., $\$ 1.50$. 100, \$11.25.

Charm (1921. 81 days.)-Pure, deep rosepink. A large and wonderful flower of beautiful shades, perfectly harmonized. A perfect blotch of deep red on lower petals. Grand and distinct. Each, 12c. Doz., $\$ 1.20$. 100, $\$ 9.00$.

Chicago (formerly named Luther Burbank) (1927. 69 days.) - A marvelous new ruffled gladiolus. Tall, fine plant with six or more magnificent, large blooms open at a time. Deep geraniumred. Border of all petals has a narrow line of a delicate bluish shade. Lower petals are beautifully feathered deeper red. Throat in upper portion of each flower is blended lighter. Several years ago I had wished to name this variety for myself as the originator of the ruffled type of gladiolus but as it was then in too limited supply I did not do so. Each, $\$ 2.00$. Doz., $\$ 20.00$.

Classic (1930. 87 days.)-Medium height, plant with five or more large flowers, beautifully and elegantly placed. Color daintiest deep salmon rose with softest clear creamy yellow throat, as beautifully blended as in any rose and as elegant and dainty a shading as in any rose. Very fine in outdoor light and extremely beautiful in artificial light. Each, 75c. Doz., \$7.50.

Color Marvel (1928. 80 days.)-Plant of fine height and appearance. Flowers large and grandly ruffled. Color a 
glowing deep vermilion scarlet. Lower petals much darker all over with very dark, velvety central narrow bars or median line. This is a flower equal in beauty and richness of color to an extra fine pansy and no variety can surpass it in richness of color. Very beautiful. Each, $\$ 1.00$. Doz., $\$ 10.00$.

Contemplation (1928. 94 days.)-Tall, strong plant with very large massive and heavily ruffled flowers. Color delicate lavender rose pink on a white ground and deeper on lower petals. Lower petals a deeper rose pink with showy red pencilings and terminating yellow. Each, \$1.00. Doz., \$10.00.

Coral Pink (1928. 69 days.)-Tall plant and large, finely ruffled flowers of a clear, deep coral pink. Lower petals same color at the edges but with a blotched, soft apricot yellow throat and feathered central bars. An exceptionally fine new ruffled gladiolus. Each, 35c. Doz., \$3.50. 100, \$26.25.

Country Gentleman (1930. 75 days.)Extra tall, graceful plant. Very large heavily ruffled flowers, beautifully formed. Color cleanest, clear canary yellow, deeper yellow on lower petals. Lower petals have long central bars which are divided into five beautifully alternating red and yellow thread lines giving the flowers a very fine appearance. An extra fine yellow. Each, 75c. Doz., \$7.50.

Crinkles (1916. 92 days.) - Deep peachblossom pink. Intensely ruffled. At Midwestern gladiolus Show, Des Moines, Sept., 1925, awarded first prize for best ruffled gladiolus, and first for best dark pink variety. Crinkles has never been produced in quantity to meet popular demand. It is one of the most outstanding varieties. Illustrated on this page. Each, 20c. Doz., \$2.00. 100, $\$ 15.00$.

Cyprian (1931)-Good height plant. Very large intensely ruffled flowers of richest creamy yellow. Lower petals delicate canary yellow with a fine pink feather half way down the center. One of the richest, showiest and very finest. Each, $\$ 1.00$. Doz., $\$ 10.00$.

Dream (1918. 86 days.)-Large, massive bloom. Deep salmon-red. Large, very showy blotches. Extra grand. Each, 10c. Doz., \$1.00. 100, $\$ 7.50$.

Dr. L. H. Bailey (1927. 72 days.)-Six to eight very large blooms open at a time on strong spike and plant. Rich, velvety tyrian rose. Throat in upper portion lighter and on lower petals very much deeper red velvety blotches. Extremely fine. Named in honor of

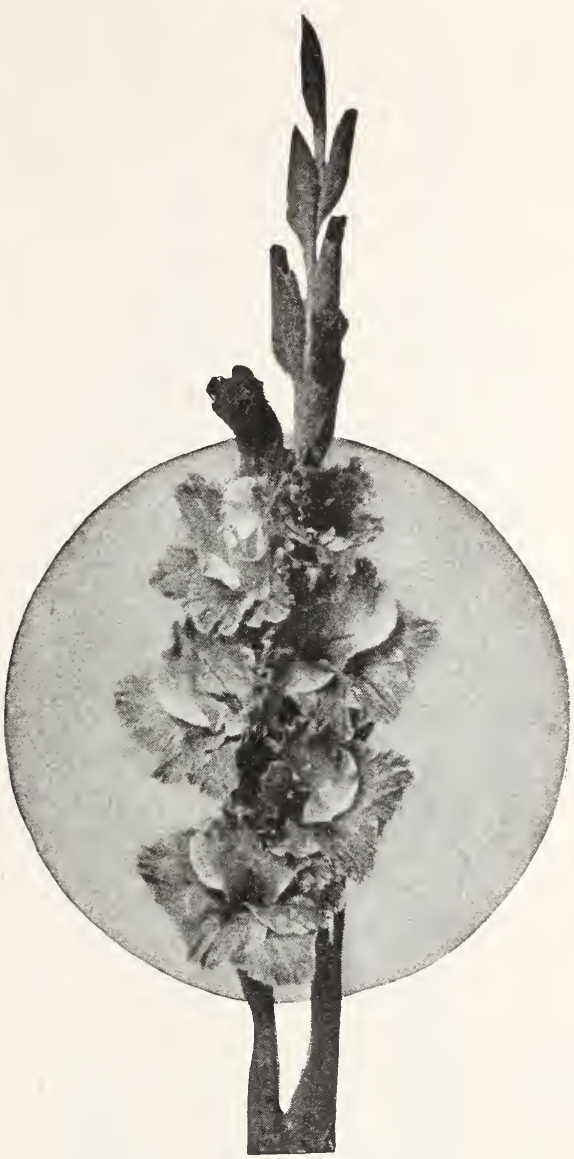

CRINKLES

Described on This Page

the great horticultural authority of Cornell. Stock very scarce. Each, $\$ 1.00$. Doz., $\$ 10.00$.

Dr. Nelson Shook (1925. 78 days.)-A giant in plant and flower. Color of deep tyrian rose. This variety created a sensation at the A. G. S. show, Rochester, Aug., 1925, and was the most talked of variety of the many thousands displayed. It also won A. G. S. Bronze Medal for best basket gladioli exhibition type; Trophy for best floor basket of gladioli; First prize for spike showing the greatest number of florets open; also, together with a basket each of Sweet Rose, Tiger, Helga and Kunderd's Yellow Wonder won the Executive Committee's Silver Cup for the five best baskets of gladioli. Illustrated on page 43. Each, 35c. Doz., \$3.50. 100, \$26.25. 
E. C. Vick (1930. 75 days.) - Fine height and showy plant. Flower, large, elegantly ruffled and six to eight open at a time. Color a deep Tyrian rose red, or medium dark rose red. A neat feathered darker red on lower throat petals. An extra showy and fine shade of rose red. Each, 75c. Doz., $\$ \mathbf{7 . 5 0}$.

E. J. Shaylor (1918. 71 days.)-Tall, very strong plant and large blooms. A beautiful, pure, deep rose-pink. Was awarded Certificate of Merit by Royal Horticultural Society of England, Aug. 10, 1920. Each, 10c. Doz., \$1.00.

Elba (1917. 77 days.)-A very largeflowered, deep lavender-rose. Deeper throat. Showy. This variety was arranged in funeral basket together with "Blanche Bollinger" and "White Butterfly" at the A. G. S. show, Rochester, Aug., 1925, and was awarded first prize, A. G. S. Trophy. Each, 15c. Doz., $\$ 1.50$. 100, \$11.25.

Evangeline Booth (1930. 74 days.)Very tall, straight fine plant and large flower. Color deep pure rose pink with large feathery rose red throat blotches. Medium ruffled. Another variety similar to $\mathrm{E}$. J. Shaylor, but tall

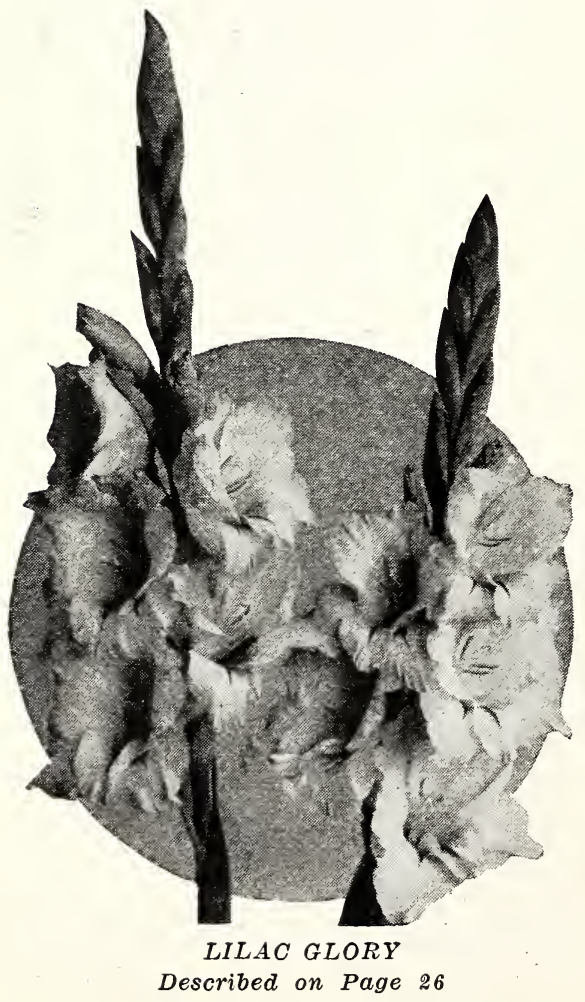

and a more showy plant. An excellent variety. Each, 50c. Doz., \$5.00.

Favorite (1921. 83 days.)-Beautiful orange-salmon, deeper in throat. Tall, strong, vigorous plant with many large, finely ruffled flowers open at a time. Very fine. Each, 15c. Doz., $\$ 1.50$. $100, \$ 11.25$.

Fern Kyle (1921. 77 days.) - A large ruffled flower of creamy white color. Vigorous grower. Creates a sensation wherever shown. Introduced at $\$ 25.00$ per bulb. Awarded first prize as best cream colored variety at A. G. S. show, Rochester, Aug., 1925. Illustrated on page 31. Each, 20c. Doz., \$2.00. 100 $\$ 15.00$.

Florence Winter (1931)-Large, tall and stately plant and very large flowers. Beautiful pure white, daintily blushed, a soft pink on outer edges of all six petals. Lower petals are deeper blushed pink on inner portion with soft creamy blush or flesh color on outer portion, ends of lower. petals of soft white daintily blushed. A very extra and showy new ruffled variety of great beauty and quality. Extra fine. Each, \$1.00. Doz., \$10.00.

Glorious (1921. 75 days.)-Tall, strong plant. Many blossoms open at a time. Soft cream color with deepest creamy apricot throat, beautifully marked. Extra choice. Each, 12c. Doz., \$1.20. 100, \$9:00.

Golden Anniversary (1929. 101 days.)Tall, strong and stately plant bearing giant perfectly placed flowers, of a beautiful fawn yellow with a suffused blush of pink. The throat has a large nicely proportioned blotch of glowing red, beautifully blended at its edges. The entire flower is well ruffled, very showy and distinct. Named in honor of the Golden Anniversary of my business. Each, \$5.00.

Golden Beauty (1928. 80 days.)-Large, showy, wide open, very deep daffodil yellow. Lower petals still deeper golden yellow with slight, beautiful, bright red central bars. Golden yellow ruffled variety extra grand. Each, 75c. Doz., \$7.50.

Golden Glory (1916. 79 days.)-A large, richly colored yellow, with beautiful throat. A fine, ruffled yellow. Each, 10c. Doz., \$1.00. 100, $\$ 7.50$.

Golden Snapdragon (1929. 66 days.) (Snapdragon Type) (Intensely ruffled) - An extraordinarily beautiful Gladiolus of the snapdragon type. The upper petals are of a refined creamy-white shade. The lower petals are also of same shade for the lower or inner half of the petals, but the outer ends are 
of a very rich, soft canary-yellow. These yellow ends are gracefully curved. This type is sure to become popular as stocks become plentiful enough to meet the demand. Each, 35c. Doz., \$3.50. 100, \$26.25.

Good Morning (1930. 71 days.)-Graceful, fair height plant. Flowers of good size, gracefully placed and five or more open at a time. Color, deepest pure deep glowing salmon red. Large creamy-white throat extending well out over the petals. These white throat blotches again have blotches which are very beautifully stippled of finest red. Medium ruffled opening buds reminds one of fine opening rose buds. An exceptionally richly colored and unusually distinct and beautiful variety. Each, 50c. Doz., $\$ 5.00$.

Hzrmonia (1928. 80 days.) - Strong plant of good, medium height. Flowers large and of a very decided and glowing, rich, deep orange-red color. Lower petals have narrow central bars with a whitish median line which is bordered with a bluish maroon narrow line on either edge. The whole flower similar, but deeper in color than "Orange Glory" and fully as showy, or more so. A very fine orange. Each, 50c. Doz., $\$ 5.00$.

Hermes (1923. 90 days.)-Large, strong plant. Very large, deep, cherry-rose flower with deeper rose on lower petals. Heavily ruffled. A grand variety. Each, 10c. Doz., $\$ 1.00$. 100, $\$ 7.50$.

Indianapolis (1916. 80 days.)--Very tall, fine deep violet; deeper throat. Slight white median lines. Beautiful. This variety was withdrawn from my list several years ago to increase the stock, as it is unusually popular and the stock was sold too close. Each, 20c. Doz., $\$ 2.00$.

Indian Summer (1917. 116 days.)-A cross between a "Kunderdii" variety and species "Quartinianus." The forerunner of a new class of gladioli. Full size bu'bs produce strong spikes with six to eight very massive ruffled flowers open at a time. Color a blush or light lavender rose-pink on a white ground. Very distinct flower and in general appearance very showy. Especially valuable to the gladiolus breeder, as it is a seed-bearing "hybrid." Each, 25c. Doz., \$2.50. 100, \$18.75.

Intensity (1928. 92 days.)-Strong, vigorous plant with large, massive, widely open flowers. Color rich, deep, bright red, darker toward outer portion. Fine rich, deep red feathered median line on lower petals. Strongly ruffled and one of the very finest ruffled varieties. Each, 35c. Doz., \$3.50. 100, \$26.25.

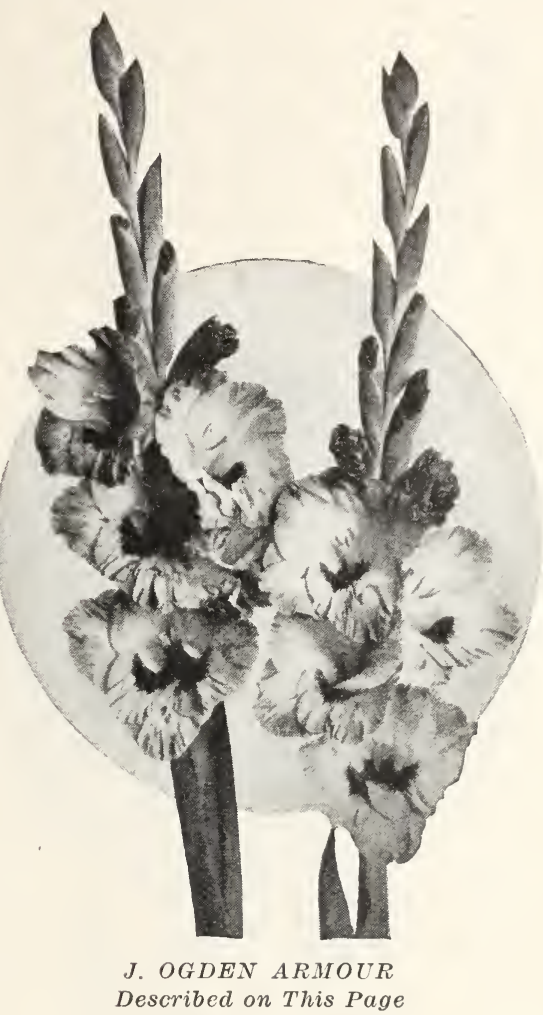

Joanna Hill (1931)-Extra strong, tall vigorous plant and large flowers with plenty open at a time. Color a most pleasing deep peach blossom pink. Much deeper large pink inner throat. A fine narrow central creamy white bar or feather extends down the center of each petal into the base of the throat, beautifully feathered white on either side near the base of the petals. A narrow white line borders all six petals and all petals are waved with broad waves, not ruffles, giving this flower a very refined and elegant form, equaled by few. An extra show and garden variety. Fine in any light, or out of doors. Each, \$3.00. Doz., \$30.00.

J. Ogden Armour (1926. 80 days.)--Tall plant with many large, beautifully placed flowers open at a time. Color of a bright coral salmon-red, lighter in the upper portion of the throat. Lower petals have large, elegant and conspicuous dark-red throat blotches. A showy and distinct new ruffled gladiolus of orchid-like appearance. Illustrated on this page. Each, 15c. Doz., \$1.50. 100, $\$ 11.25$. 


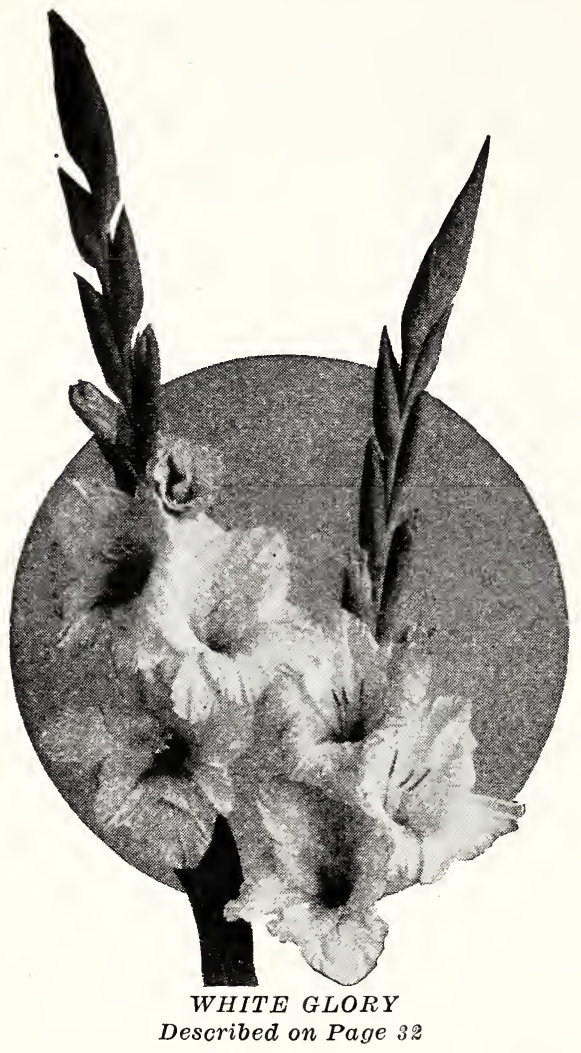

Joy (1923. 85 days.)-Extra fine, purest flesh color with daintily tinted soft canary or cream throat, finely marked pink. Very unusual and fine. Illustrated on inside back cover. Each, 12c. Doz., $\$ 1.20$. $100, \$ 9.00$.

Julius Rosenwald (1931)-Tall, stately plant. Large flowers of most beautiful orange salmon color. Large central upper petal very upright giving the flowers a striking appearance. Lower petals have large blotches of a very showy blush color. Easily among the most attractive and beautiful of all Gladioli. Each, 75c. Doz., \$7.50.

Kasson (1917. 73 days.)-Large, lavender rose-pink with deeper rose-pink throat. Finely ruffled. Each, 8c. Doz., 80c. $100, \$ 6.00$.

Kunderdii Glory (1907. 77 days.)-Beautiful, creamy apricot with light tint of pink, and fine markings of red on lower petals. Can be grown over five feet tall with high culture. This is the first scientifically produced Ruffled Gladiolus ever sent out. It has received many certificates and awards, is known all over the world, and is the parent of many new varieties. Illustrated on front cover. Each, 10c. Doz., $\$ 1.00$.

Kunderd's Apple Blossom (1923. 77 days.)-Apple blossom color. Tall, fine plant and spike. Very refined and beautiful. Each, 10c. Doz., \$1.00 100, \$7.50.

Kunderd's Wild Rose (1927. 83 days.)Tall, strong, massive plant with many large and intensely ruffled flowers open at a time. Color beautiful, wild-rose with lavender tint. Throat deeper lavender. Heavily ruffled. Illustrated on page 30. Each, 15c. Doz., \$1.50. 100, $\$ 11.25$.

Lavender Frills (1931.)-Fine, good height plant and good size flower, very ruffled and widely open. Color richest pure deep lavender with large pure white throat. White median lines on all petals. A blendirfg of white and richest deep lavender hard to describe and of most pleasing effect. A color much needed. Each, 75c. Doz., \$7.50.

Lavender Pride (1928. 79 days.)-Fine, tall plant, large, wide open flowers of a deep, lavender rose color, beautiful throat of a deeper rose or purplish lavender rose. A splendid and showy flower in good supply. Each, 15c. Doz., $\$ 1.50$. 100, \$11.25.

Lela (1928. 69 days.) -Fine plant with good sized flowers and beautifully ruffled. Upper petals dainty cream very daintily blushed softest flesh pink. A soft, deep creamy apricot over entire lower petals, with only a delicate pink slight central bar on inner portion. Very fine. Each, 35c. Doz., \$3.50. 100, $\$ 26.25$.

Lilac Glory (1923. 84 days.)-Large flowers, many open. Soft lilac rose-pink. Beautiful, deeper lilac rose and pink throat. Kunderdii Glory type. Illustrated on inside back cover. Each, 12c. Doz., \$1.20. 100, \$9.00.

Lilith (1918. 79 days.)-Color orangesalmon. Heavily ruffled. Good height, average four or five flowers open; one of the best ruffled varieties. This variety had to be withdrawn from my list for a number of years to increase stock. Illustrated on page 49. Each, 20c. Doz., \$2.00. 100, $\$ 15.00$.

Lily of Gold (1928. 66 days.) - A sturdy, straight plant of medium height. Flowers five and six or more open at a time and very large and of wide open diamond form. Gracefully and widely open upper petals. Upper central petal extremely large and upright, giving the flower a very striking appearance. (Flowers very evenly and perfectly placed.) In every way a remarkable and wonderful flower. Many pronounce it the greatest of all Gladioli. Scarce, but a very rapid multiplier. Color, rich 
canary yellow, a little deeper on lower petals. Each, $\$ 3.00$. Doz., $\$ 30.00$.

Maimonides (1928. 83 days.)-Fine, strong plant. Flowers large and massive and facing perfectly one way. Color pure snow white on all six petals. Lower petals have a showy and beautiful blotch of red. The entire flower is intensely ruffled, very showy and distinct. Each, $\$ 1.00$. Doz., $\$ 10.00$.

Marshal Foch (1922. 84 days.)-One of the sensations at the American Gladiolus Society's show in August and wherever shown at the big exhibitions. Many giant flowers open at a time on very strong stem and plant. Color of finest salmon-pink. Almost self-color. Each, 15c. Doz., \$1.50.

Marie Kunderd (1918. 69 days.) -A wonderful white, very early. Of purest white with an almost invisible soft pink line in center of lower petals. Grandest of all whites. Awarded First Class Certificate of Merit by North Shore Horticultural Society, Manchester, Mass., summer of 1919. Blooms of this variety worked into a beautiful bride's bouquet and displayed at the A. G. S. show, Rochester, Aug., 1925, awarded first prize A.G.S. Bronze Medal. First prize was awarded this variety at the $1926 \mathrm{~A}$. G. S. show as the best white variety. Also at the same show, it was used in my cross design with Purple Queen and won another A. G. S. Trophy. Illustrated on this page. Each, 20c. Doz., \$2.0.0. $100, \$ 15.00$.

Masterpiece (1921. 81 days.)-A magnificent ruffled "American Beauty" rose color. Giant flower and plant. Extremely fine. Each, 12c. Doz., \$1.20. $100, \$ 9.00$.

Meadow Lark (1930. 77 days.)-Tall, stately plant with large widely expanded flowers. Petals long, pointed, beautifully curved like a fine lily. Color, dark velvety orange red. Throat is beautifully barred with rich, deep and pencil lines on a fine shade of yellow. In every way a distinct and showy flower. Each, 35c. Doz., \$3.50. $100, \$ 26.25$.

Mikail (1931)-A tall stately plant and very large flower of remarkable and extraordinary color, as beautiful as any Gloxinia and as rich in color. Ground color a beautiful purple or violet rose pink, flaked a fine rose red. Entire inner throat covered with a wonderful pansy or Gloxinia-like blotch of intense velvety dark red, again bordered and mottled. A delicate creamy border. In every way a remarkable striking and showy flower. Each, $\$ 2.00$. Doz., $\$ 20.00$.
Mona Lisa (1917. 78 days.)-Strong plant. Many flowers open at a time. Of palest soft rose-pink, or blushed white. A magnificent, almost pure selfcolor. One of the most delicate and refined shades ever produced. Each, 10c. Doz., \$1.00. 100, \$7.50.

Morning Sunshine (1930. 83 days.)-Tall, stately plant with five or more showy flowers open at a time. Color, deep salmon pink, deeper towards outer edges. Throat a delicate creamy pink on a lighter ground. A refined distinct and beautiful flower. Each, 50c. Doz., \$5.00.

Mrs. Dr. Bevan (1931)-Very tall and stately plant with five or more very large flowers open at a time. Flowers widely expanded and upper central petal placed very upright giving the individual blossom a very distinct and striking appearance. Color of upper petals and ends of lower petals of purest white with faintest tint of cream. Lower petals are almost covered with wonderful blotches of a deep golden cream with only a very narrow central thread line of softest rose pink half the length of the petals. A very refined and elegant flower. One of the

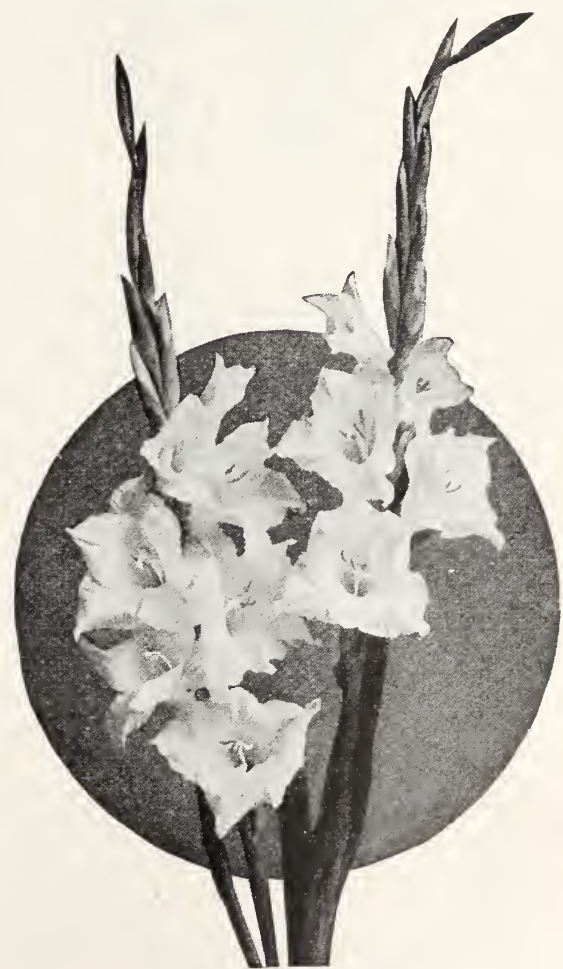

MARIE KUNDERD Described on This Page 


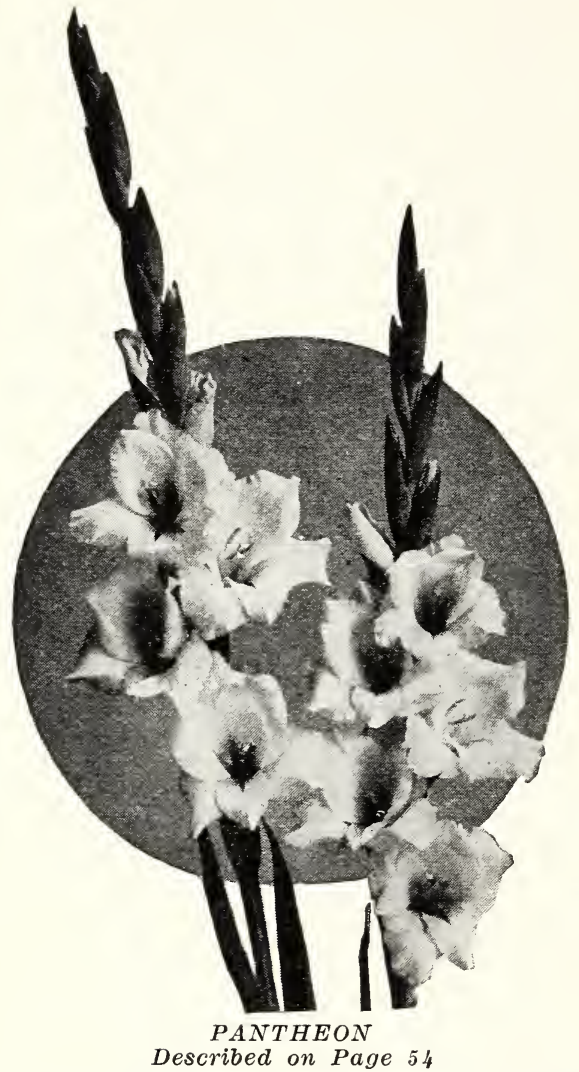

finest I have ever introduced, a very magnificent and beautifully ruffled variety. Each, $\$ 1.00$. Doz., \$10.00.

Mrs. Laurance Armour (1931) - Tall strong plant, large flowers widely expanded. Ground color white with a fine soft rose pink over upper petals. Lower petals somewhat lighter and have blotches almost as fine as Pendleton. A much improved Bothin, finer colors and more ruffled. Very choice and fine. Each, 75c. Doz., \$7.50.

Natalie (1923. 84 days.)-Finest, deep orange-salmon. Deeper color on lower petals. Neat, short white line extending from throat markings. A beautiful and distinct variety. Tall, fine plant and showy flower. Each, 8c. Doz., 80c. $100, \$ 6.00$.

Ne Plus Uitra (1928. 74 days.)-Tall, fine plant with a large, elegantly ruffled flower of most beautiful deep, rich cream in color and has a lovely marking of fine red and finely penciled central base. One of the most beautiful varieties ever produced and fine for every purpose. Very beautiful, Each, 50c. Doz., $\$ 5.00$.
New York (1928. 76 days.)-A fine plant and large flowers. Wide open and upper petals beautiful, upright. Color a rich rose red and lower petals have a fine, deep red blotch. A very fine and beautifully ruffled variety. Sure to please. Each, 25c. Doz., \$2.50. 100, \$18.75.

Ophelia (1930. 75 days.)-Tall, stately plant with massive flowers. Petals extra wide and of pure deep rose pink, lighter in upper throat, but all six are much deeper rose towards outer edges. Lower portion of flower has a wide feathered bar of deep velvety rose red flamed bright red at either side. Opening buds as beautiful as opening rose buds. An extra fine and showy variety and a splendid florist flower. Each, 75c. Doz., \$7.50.

Oran (1918. 80 days.)-Blushed white, a little deeper than "America." Rose and white penciled throat. Each, 10c. Doz., $\$ 1.00$. 100, $\$ 7.50$.

Orange Feather (1930. 84 days.)-Good height plant and good sized butterfly shaped flowers, strongly ruffled. Color, light orange yellow, flaked beautifully a deep orange, giving the flower much the appearance of the beautiful "Alice Tiplady," only a little lighter in color. A pleasing and very attractive new ruffled variety. Each, 50c. Doz., \$5.00.

Orange Fires (1930. 79 days.)-Medium height and fine plant, with large massive and beautifully ruffled flowers. Color, dark vermilion red. Large throat blotches of deep purplish red with white central lines extending well towards the ends of the petals, giving a very striking and showy effect. A distinct addition to the ruffled list of Gladioli. Each, 75c. Doz., \$7.50.

Orange Lily (1930. 65 days.)-Good height plant with giant massive flowers, beautifully ruffled. Upper petals a fine orange color. Lower petals of purest soft chrome yellow, covering entire petals, excepting edges and tips of lower portions. A very magnificent and grand variety. Each, $\$ 1.00$. Doz., $\$ 10.00$.

Orchid Butterfly (1930. 62 days.)-Tall and stately plant with very large widely expanded flowers of deepest salmon flesh color. Ends of lower petals of same color as upper petals. Throat elegantly stippled a soft dark red with most of lower petals a very beautiful shade of a delicate straw or creamy yellow. A very orchid or butterfly like flower suggestive of its name. Tall and majestic. Each, 75c. Doz., $\$ 7.50$. 
Otto Carmichael (1931) - Fine, tall stately plant with many large and very showy flowers open at a time. Color intense deep yellow of a rich golden tinge, intensely ruffled. Outer border of the petals are richly blushed or tinted a beautiful golden tone still deeper with soft pink flush. Lower petals have soft rose pink narrow feathered central lines. A truly magnificent golden yellow named for a distinguished and famous Hoosier. Each, \$3.00. Doz., \$30.00.

Peep O'Day (1921. 79 days.) - Tall, beautiful blushed pink on white ground. Long, feather barred throat. Illustrated on page 49. Grand. Each, 12c. Doz., $\$ 1.20$. 100, $\$ 9.00$.

Pink Cloud (1923. 77 days.)-A large, distinct, showy, ruffled variety. Usually seven to nine beautiful, soft rose-pink blossoms open at a time. A very beautiful, deeper rose throat. Received first prize at the $1926 \mathrm{~A}$. G. S. show as the best pink variety exhibited. Illustrated on page 49. Each, 15c. Doz., \$1.50. 100, $\$ 11.25$.

Pink Lily (1916. 77 days.)-A magnificently ruffled rose-pink. Grand. Illustrated on page 49. Each, 12c. Doz., $\$ 1.20$. $100, \$ 9.00$.

Pink Pencil (1930. 90 days.)-Medium height plant with five and more large flowers open at a time. Color a fine tone of flesh softly flaked or delicately blushed a little deeper towards the outer edges of the petals. Throat finely feathered with lightly penciled white and pink penciled thread lines in beautiful effect. Each, 35c. Doz., \$3.50. 100, $\$ 26.25$.

Pride of Goshen (1915. 85 days.)-A giant "Kunderdii Glory" of a salmon or flesh-pink. Flowers very large and petals elegantly waved. Exceptionally tall and vigorous plant. General appearance imposing. Illustrated on this page. Each, 15c. Doz., \$1.50.

Primora (1928. 76 days.)-Tall, fine, strong plant. Flowers large and showy and wide open, upper petal upright. Color a delicate rose pink on a blush white ground considerably deeper pink towards outer edges of all the petals. Lower petals have a beautiful rosered blotch nicely feathered with beautiful deeper red central bars. Each, 35c. Doz., \$3.50. 100, \$26.25.

Purple Glory (1916. 79 days.)-The giant of the Kunderdii Glory race, and of remarkable color. Deepest velvety maroon-red, with almost black blotches, like burned into petals. Beautifully ruffled. Extraordinary. This variety was awarded silver cups at two different shows for "Best variety at the show," and several medals during 1923.
Awarded first prize A. G.S. show, Rochester, Aug., 1925, in the dark-red and maroon class. Winner of hundreds of other awards. Illustrated on inside front cover. Each, 12c. Doz., \$1.20. 100, $\$ 9.00$.

Purple Queen (1925. 73 days.) - A deep violet-purple beauty. Throat darker, medium ruffled. A wonderfully arranged funeral piece of this variety was exhibited by me at the A. G. S. show, Rochester, Aug., 1925, and was awarded first prize, A. G. S. Bronze Medal. Winner of two trophies and two other first prizes, 1926 A. G. S. show. Illustrated on inside back cover. Each, 20c. Doz., $\$ 2.00$. $100, \$ 15.00$.

Quantico (1929. 80 days.) - Strong vigorous plant of good height with five or more large massive blooms open at once. Color fine rose pink over all six petals. Lower petals have large bright deep red blotches on clear creamywhite ground. Reminds one of a ruffled "Pendleton." Each, 20c. Doz., $\$ 2.00$. 100, $\$ 15.00$.

Red Ribbon (1928. 84 days.)-Tall, fine plant, large flowers on strong, nice stems. Color deep rhodamine purple red. Throat deeper red. Upper portion of throat much lighter than the main portion of petals. Each, 20c. Doz., \$2.00. $100, \$ 15.00$.

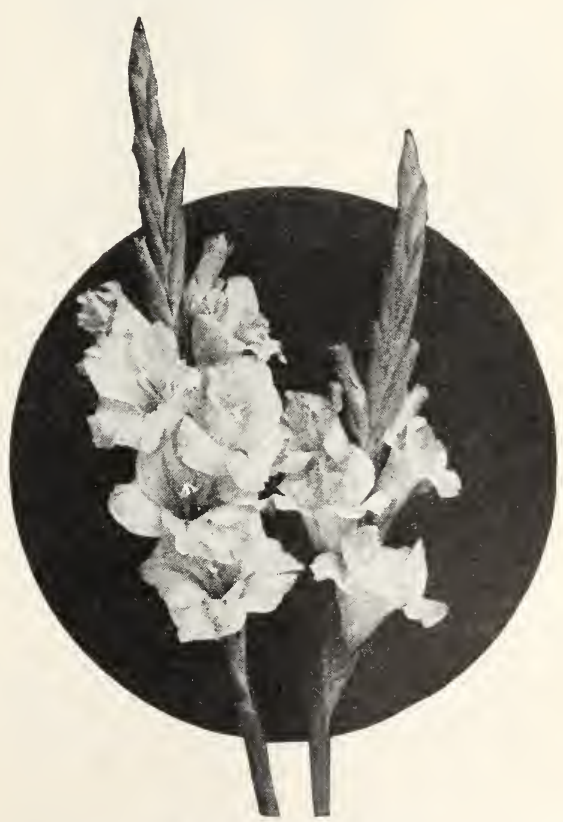

PRIDE OF GOSHEN Described on This Page 


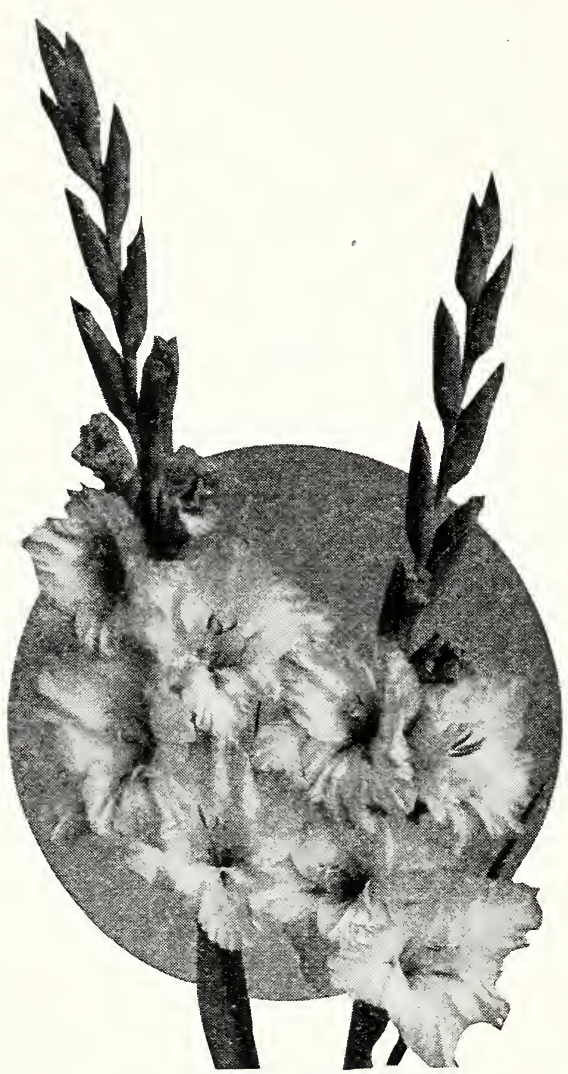

KUNDERD'S WILD ROSE

Described on Page 26 .

Ret Splendor (1928. 77 days.)-Strong, good height plant, with large and massive wide open flowers. Lower petals almost as large as upper ones. Color a decidedly brilliant scarlet with lower petals a deeper, rich velvety red of the ruffled type, but only moderately ruffled. A different, gorgeous and showy red. Very extra. Each, 50c. Doz., $\$ 5.00$.

Reo (1929. 80 days.)-Tall grand plant. Flowers large and of a distinct deep dark ruby red. Medium ruffled. A grand deep red of very distinct and attractive appearance. Each, 25c. Doz., $\$ 2.50$. 100, $\$ 18.75$.

Rosalind (1918. 70 days.)-Dark, analine-red, deeper throat. Very popular and often spoken of as one of my best productions. Distinct and grand. Each, 12c. Doz., \$1.20. 100, $\$ 9.00$.

Rose Glory (1916. 77 days.) - A very large and beautiful ruffled variety. Purest rose-pink color. Deeper in throat. Extra fine. Winner of hundreds of awards. Illustrated on inside back cover. Each, 10c. Doz., \$1.00.

Rosemary Hayes (1930. 77 days.) - Tall fine plant with six or more large flowers open at a time. Color bright rich rose, lighter in upper portion with nearly white, subdued lines on center bars of upper petals. Lower petals have narrow dark red bars in midrib with finely feathered alternate red and white thread lines on either side. Kunderdii ruffled type, lightly ruffled. A fine showy plant and flower. Beautiful. Each, 50c. Doz., \$5.00.

Ruffled Splendor (1928. 72 days.)--Medium tall and very vigorous plant. Flowers very large with five or more massive, perfectly placed blooms open at a time. Upper petals and ends of lower petals of a decidedly rich and showy, pure, self colored, deep salmonrose pink. Throat blotches extremely showy and fine, over the entire breadth of the broad lower petals. The blotches are beautifully penciled with fine veins of beautiful red with dark velvety red central bar or median line. The blotches are more showy than in "Pendleton." Few gladioli can equal it. Each, 50c. Doz., \$5.00.

Ruth Huntington (1923. 82 days.)Beautiful violet lilac with deeper lilac markings on lower petals. Large, strong plant with tall, fine spikes. A general favorite. Illustrated on inside front cover. Each, 10c. Doz., $\$ 1.00$. 100, $\$ 7.50$.

Salmon Plume (1921. 69 days.)-Clear salmon flesh, deeper at edges of petals. A pretty red throat. Choice. Each, 10c. Doz., \$1.00. 100, $\$ 7.50$.

Salmon Ruffles (1930. 83 days.)-Nice height plant and fine spike. Color a bright deep salmon rose red. Very pure and even color all over with a beautifully formed humming bird shape blotch of deep red on lower petals. A choice and beautiful Gladiolus. Each, 35c. Doz., \$3.50. 100, \$26.25.

Scarlet Glory (1917. 86 days.)-In plant and flower much like "Kunderdii Glory," but not so deeply ruffled. A very fine red, of rich, distinct shade. Each, 10c. Doz., \$1.00. 100, \$7.50.

Smiles (1921. 82 days.)-Large flower of the Glory type. White petals with fine rose-pink on outer edges. Splendid. Each, 10c. Doz., \$1.00. 100, \$7.50.

Smiling On (1930. 89 days.)-Fine medium height plant with five or more large very ruffled flowers open at a time. Fine rose pink, covering the entire flower very uniformly, excepting 
a very large and beautiful blotch of pure red in the center of all the lower petals. These blotches have the rose pink of the ground color extending down their sides setting out the blotches very effectively. A rich and showy new ruffled variety. Each, 75c. Doz., $\$ 7.50$.

Snapdragon (1915. 68 days.) (Snapdragon Type.)-Tall spike, fair sized flower. Reminds one of a snapdragon in its remarkable form. Large, rich, pure yellow throat with bright-red border. Exceptionally distinct and beautifully ruffled. Each, 15c. Doz., $\$ 1.50$. 100, \$11.25.

Snow Glory (1917. 80 days.)-Of purest all white, with only slight clear irisblue lines on lower petals. Very large and very showy. A wonderful flower. Winner of many awards. Each, 25c. Doz., \$2.50. 100, \$18.75.

Song of the Lark (1930. 90 days.)-Fine medium height plant and large flowers very evenly placed. Color a very fresh tone of salmon rose flaked softly a deeper orange salmon. Lower petals on outer portion of center, a soft creamy white, extending with a narrow central line of same color downward into the throat in a beautiful light bright rose red, divided by the white central median line. A very cheery and refreshing color and an outstanding and beautiful variety. Each, 35c. Doz., \$3.50. 100, \$26.25.

Southern Beauty (1931)-Tall fine plant, good size blooms with plenty open at a time. Color intense salmon rose. A little lighter in upper portion. Lower throat beautifully penciled deeper rose red and delicately subdued white, with still deeper central bars of rose red. Lightly red on all petals. A beautiful and distinct variety. Each, 50c. Doz., $\$ 5.00$.

Southland Queen (1931)-Fine height plant, good sized flower. Color of richest deep tyrian red or American Beauty rose, faintly flaked deeper on outer edges of petals. Upper portion of throat blushed lighter. Lower portion of throat beautifully penciled with a soft old gold on deeply colored American Beauty rose. A very distinct showy and beautiful color combination. A fine new ruffled variety. Each, 75c. Doz., \$7.50.

Star Lily (1929. 84 days.)-Tall strong vigorous plant and giant flowers of a deep sulphur or light canary yellow. Lower petals only a little deeper canary yellow without any other coloring or markings. Strongly ruffled. A magnificent giant self colored variety. An extra fine "self." Each 35c. Doz., $\$ 3.50$. 100, $\$ 26.25$.

Sulphur Frills (1923. 76 days.)-Tall, many medium sized flowers open at a time. Beautifully ruffled, of finest, pure, soft, sulphur shade. A real wonder. Illustrated on inside front cover. Each, 15c. Doz., \$1.50. 100, \$11.25.

Sulphur Glow (1921. 74 days.) - A beautiful shade of sulphur-yellow. Many well-expanded, intensely ruffled flowers open at a time. Each, 12c. Doz., \$1.20. $100, \$ 9.00$.

Tanager (1930. 73 days.)-Good height plant and good sized blooms. Form of flowers often upright. Color clear orange flaked slightly a deeper orange towards the outer portion. Throat beautifully golden orange edged beautifully with a bright lighter orange. Elegant and beautiful. Each, 35c. Doz., $\$ 3.50$. 100, $\$ 26.25$.

Tempa (1917. 80 days.)-Pink ground. Old rose, bronzy lavender throat. Distinct and fine. A popular variety at the A.G.S. show, Rochester, Aug., 1925. Each, 10c. Doz., \$1.00. 100, \$7.50.

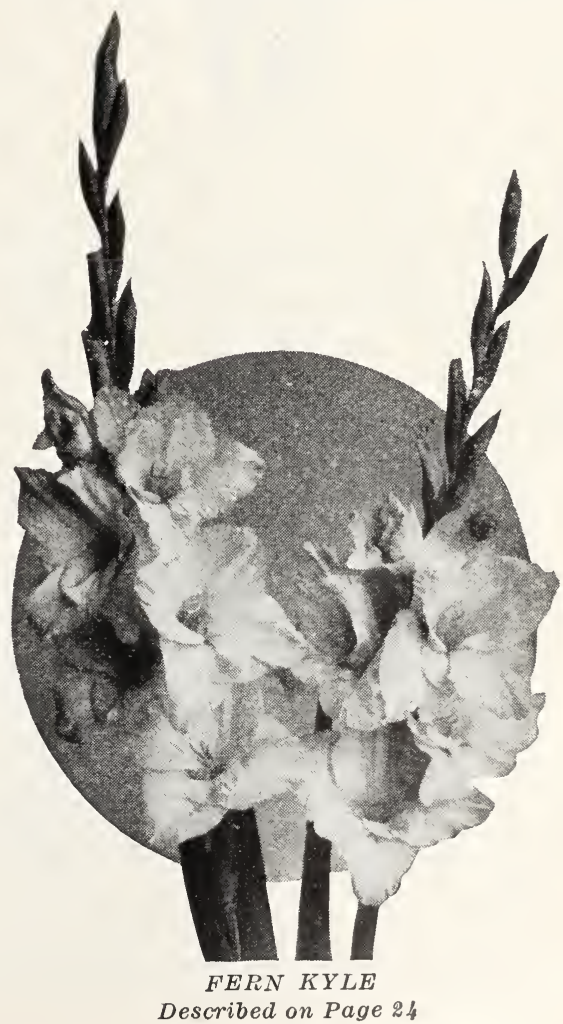




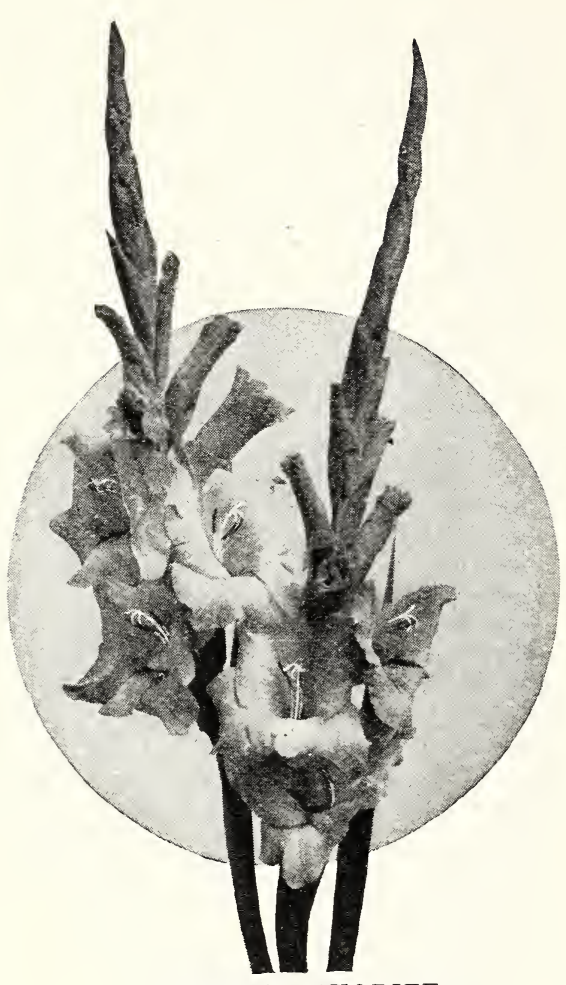

YOUELL'S FAVORITE Described on This Page

Thistle (1921. 77 days.)-Large, rosered flower of very open and perfect form. Pretty, large pansy-like throat markings. Tall, stately plant, extra choice. Each, 12c. Doz., \$1.20. 100 $\$ 9.00$.

Thomas A. Edison (1929. 77 days.)-An extraordinary gladiolus named by special permission of the great wizard of inventions. Color an unusually velvety, dark blood-red. A very large and perfectly placed wide open flower-wonderfully formed and heavily ruffled. Six and seven open at a time. This variety is always greatly admired by visitors, and I am sure it will eventually be found in every first-class collection of gladioli. Very few for sale this season. Each, \$2.00. Doz., \$20.00.

Tippecanoe (1929. 97 days.)-Good fine strong plant with numerous large wide flowers open at a time. Color is "America" over again with a similar feather bar a little larger on lower petals, and the flower is beautifully ruffled. This variety won the first prize for best new seedling when shown in
1925 at the Mid-Western Gladiolus Society Show held at Des Moines, Iowa. Each, 25c. Doz., \$2.50. 100, \$18.75.

Twilight (1921. 85 days.)-Beautifully blushed creamy-buff with throat of grandest yellow and pink. Magnificent. Illustrated on inside front cover. Each, 12c. Doz., $\$ 1.20$. 100, $\$ 9.00$.

Violet Glory (1916. 70 days.)-Massive flower. Rich, self-color deep violet; deeper throat. Medium ruffled. Extra. Each, 12c. Doz., \$1.20. 100, \$9.00.

Western Sunset (1930. 90 days.)-Medium tall, fine plant with 6 to 8 or more very evenly placed flowers open at a time. Color dark velvety blood red, flaked dark rose red at outer border of all the petals. Throat a little darker. Almost a perfect "self" color, showy, rich and beautiful variety. Each, 35c. Doz., \$3.50. 100, \$26.25.

White Glory (1915. 79 days.)-A gorgeous, pure white of exact size and type as "Kunderdii Glory," with beautiful iris-blue throat. Fine as a delicate iris. Grand. Winner of many awards. Illustrated on page 26. Each, 12c. Doz., $\$ 1.20$. 100, $\$ 9.00$.

Wonder Glory (1930. 80 days.)-Very tall, very strong and massive plant and flower. Five or more immense massive flowers open at a time. Color richest deep golden cream daintily blushed, deepening towards the edges of the petals. Most of lower petals a dainty soft canary yellow with beautiful long feather bars extending half their length. Extra grand in every way and surpassed by no other variety in striking and showy appearance. I want to give my friends this rare treat with such a wonderful flower at a very moderate price of Each, \$3.00. Doz., $\$ 30.00$.

Youell's Favorite (1915. 95 days.)-One of Henry Youell's (Sec'y Am. Gladiolus Society) favorites among our ruffled varieties. Large flower and plant. Striking rosy lavender-pink. Conspicuous and fine. Illustrated on this page. Each, 10c. Doz., \$1.00. 100, $\$ 7.50$.

See Collection Offers on Following Page

\footnotetext{
Mrs. Clyde Mcclain, Pa. July 9, 1931.

I received my Gladioli and oh, how well pleased I am with them. They are the nicest ones I ever got; the way they were packed and put up. Everyone came up and they would make two, very near three, of the other ones that are up.

My neighbors think they are the nicest bulbs, and put up the nicest of any they ever saw. Everyone around here loves flowers, and they are all watching them grow.

Hoping to receive a Fall catalog from you.
} 


\section{Collection Offers}

\section{RUFFLED GLADIOLI-KUNDERDII}

These Collections Are All Sent with Each Variety Properly Labeled

Collection No. 9-All varieties valued up to and including 10c, 19 bulbs in all (value $\$ 1.86$ ) for .......\$1.70

Collection No. 10-All varieties valued up to and including $12 \mathrm{c}$ 37 bulbs in all (value $\$ 4.02$ ) for ...... $\$ 3.60$

Collection No. 11-All varieties valued up to and including 15c, 48 bulbs in all (value $\$ 5.67$ ) for.......\$5.10

Collection No. 12-All varieties valued up to and including $20 \mathrm{c}$, 56 bulbs in all (value $\$ 7.27$ ) for.......\$6.55

Collection No. 13-All varieties valued up to and including $25 \mathrm{c}$, 64 bulbs in all (value $\$ 9.27$ ) for.......\$8.35

Collection No. 14-All varieties valued up to and including 35c, 78 bulbs in all (value $\$ 14.17$ ) for..... \$12.75

Collection No. 15-All varieties valued up to and including 50c, 91 bulbs in all (value $\$ 20.67$ ) for..... \$17.60 Collection No. 16-All varieties valued up to and including $75 \mathrm{c}$, 103 bulbs in all (value \$29.67) for.... \$25.25

Collection No. 17-All varieties valued up to and including $\$ 1.00$, 111 bulbs in all (value $\$ 37.67$ ) for . ... \$32.05 Collection No. 18-All varieties valued up to and including $\$ 2.00$, 114 bulbs in all (value $\$ 43.67$ ) for.... \$37.15 Collection No. 19-All varieties valued up to and including $\$ 3.00$, 118 bulbs in all (value $\$ 55.67$ ) for.... $\$ 47.35$

Collection No. 20-All varieties valued up to and including $\$ 5.00$, 119 bulbs in all (value $\$ 60.67$ ) for .... $\$ 51.60$ Collection No.21-Entire collection, one each of the 120 varieties listed (value $\$ 70.67$ ) for...... $\$ 60.10$

\section{VARIETIES CONTAINED IN THESE COLLECTIONS ARE FOUND IN PAGES 21 TO 32}

\footnotetext{
R. H. Moore, Canada. May $2,1931$.

My order of Gladiolus bulbs arrived today, and I am more than pleased wit them. They are the finest, cleanest lot of bulbs I have seen. They would need to be perfect to get by the Canadian inspectors of imported plant products, for they are very strict. As a matter of fact some American growers refuse to accept Canadian orders because of so large a percentage of rejections.
}

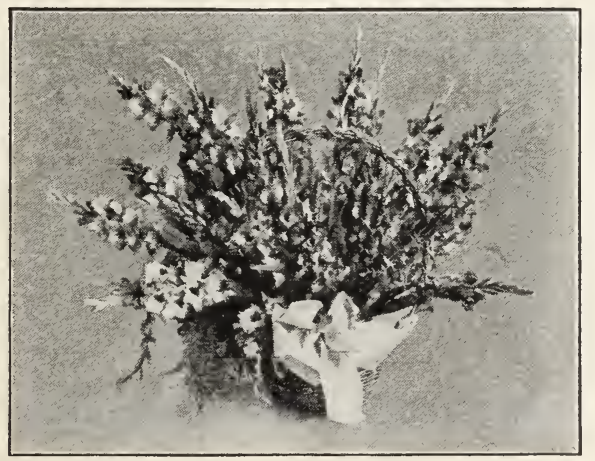

Mrs. Archer J. Beard, Ohio.

Two years ago I got one of your rainbow Gladiolus collections. They were most beau tiful flowers that have ever grown in $\mathrm{my}$ garden.

A. Braem, Michigan. I take pleasure in informing you that the bulbs ordered by father in $\mathrm{Bel}$ i um have I therefore, thank you for the good Kun derd service offered, and will gladly recom-

mend same on eve

Average Gladioli Prices $60 \%$ Reduced This Year 


\section{Plain Petaled Varieties with Records That Have $\mathcal{X}$ (ever Been Equalled}

Many of the names of the Gladioli appearing in this list have been carved into medals, engraved upon certificates and chiseled into loving cups. Meritorious awards have followed these Gladioli through a long period of popularity. Many of them have never been equalled for beauty, type and perfection. Their names will live forever, and their beauty will always be loved and enjoyed. Because of these extremely low prices you will be able to enjoy more of these famous Gladioli in your garden.

Achillas (1928. 76 days.)-A tall, strong plant. Giant, deep orange red flowers with very beautiful and showy, large, vermilion scarlet throat blotches. Edges of blotches and base of throat daintily stippled with richest yellow. A magnificent, large and showy flower in every way. Each, 75c. Doz., \$7.50.

Agnes Ball (1931)-Fine, medium tall plant with ample blooms open at a time. Color most beautiful red with very large white throat. This is a pure self fertilized seedling of "Princeps" of better and purer colors. The best Princeps seedling which I have ever

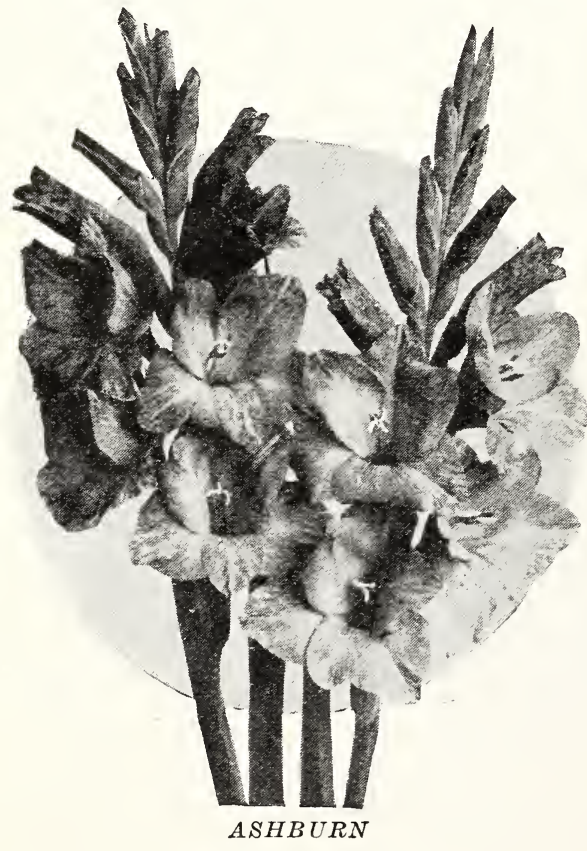

Described on Page 35 seen. A grand garden and show variety. Each, \$2.00. Doz., $\$ 20.00$.

Al Smith (1929. 66 days.)-Tall, strong plant and large flowers perfectly placed on spikes and perfectly facing one way. Color of finest and purest salmon rose slightly flaked deep salmon red on outer tips of petals. Lower petals deeper on inner throat half portion with a very beautiful purplish central bar which is paralleled with fine veinings, interspersed with delicate pencilings of soft yellow, giving the whole a very beautiful effect. Easily one of the most beautiful of all Gladioli. Each, 50c. Doz., $\$ 5.00$.

Ambrosia (1929. 72 days.)-Tall, fine plant with five or more large and showy blooms open at a time. Color the most refined old rose imaginable with giant blotch of beautiful deep yellow which again has a fine blotch of rich red extending down into the throat. An extraordinary showy and beautiful flower. Each, $\$ 2.00$. Doz., $\$ 20.00$.

Anna Mae (1931) - Tall, strong plant. Flowers large and plenty open at once. Color a creamy white, faintly blushed flesh pink over outer portion of petals. Lower portion of throat a soft canary yellow or deep cream. Colors finely blended. A showy and pleasing flower. Slightly ruffled. Illustrated on page 50 . Each, 50c. Doz., \$5.00.

Anne Nielsen (1930. 81 days.)-A fine height plant with a giant flower. Petals broad, long pointed and recurved. Color of brightest, rich deep shrimp pink, lighter towards the throat. Large light creamy white throat on lower petals deepening to richest soft clear canary yellow on inner half of the petals. Reminds of "Pauline Kunderd," equally fine, but different shade and color. Very showy and fine. Each, 75c. Doz., $\$ 7.50$. 
Anthony Zonker (1922. 96 days.) -Extra tall, strong plant with five to seven very large, wide open blooms open at a time. Finest deep salmon-rose, beautifully placed. Lower petals as beautifully blotched as "Pendleton." A distinct and showy fiower named for a grand old man, my mother's father. Classed among the best. Each, 10c. Doz., \$1.00. 100, \$7.50.

Antonia Antonette (1926. 80 days.)Tall, strong plant with many flowers open at a time. Color, a very striking salmon rose-pink. Neat throat marking of deeper pink and white, finely blended. A very unusual and beautiful pink of grand appearance. Each, 12c. Doz., \$1.20. 100, $\$ 9.00$.

Arthur Brisbane (1928. 71 days.)-Tall, handsome plant with large, wide open, deep rose pink or light rose red flowers and beautiful, deeper rose red towards the outer petals. Large, deep red throat blotches, with a deeper, velvety red in center of blotches. As finely marked as a pansy. A very beautiful Gladiolus. Each, 20c. Doz., \$2.00. $100, \$ 15.00$.

Arthur Cowee (1930. 73 days.)-Good height and fine plant. Flowers quite large and five to six open at a time. Color of richest deep clear salmon red. Outer one-half portion of lower petals of same color. Inner portion of glowing fiery salmon red, beautifully feathered with fine alternating lines of beautiful dark red and central bars on a clear white feathered throat. A magnificent flower. Each, \$1.00. Doz., $\$ 10.00$.

Ashburn (1917. 70 days.) - A very massive salmon-red, flaked deeper. Showy. Illustrated on page 34. Each, 10c. Doz., $\$ 1.00$. 100, $\$ 7.50$.

Atreus (1921. 77 days.)-Grandest, pure rose-pink of most delicate shade. Strong grower and very, very beautiful. Each, 10c. Doz., \$1.00. 100, \$7.50.

Autumn Colors (1928. 145 days.)-Strong plant with large flowers. Quartinianus type. Autumn flowering. Color a bright orange red with light yellow throat markings. Fine for fall blooming. Each, 35c. Doz., \$3.50 100, \$26.25.

Avantis (1928. 72 days.)-Tall, strong plant. Large flower of Pendleton type. Lavender purple on a white ground. Large and showy deep purple, claret blotch covering entire width from throat and fully three-fourths of broad lower petals. Unusual. Fach, 75c. Doz., $\$ 7.50$.

Battle Creek (1923. 71 days.)-An at-

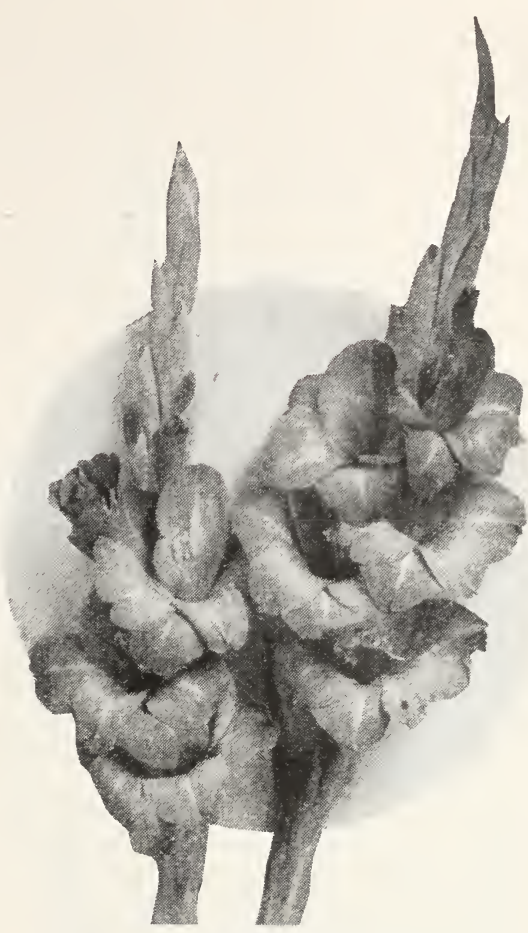

SCARLET PRINCEPS

Described on Page 61

tractive, almost self-colored deepviolet, a little deeper in throat. Good size and many open at a time. Each, 8c. Doz., 80c. 100, $\$ 6.00$.

Beauty Flower (1929. 95 days.)-Fine medium tall plant with ample wide open flowers in bloom at a time. In color a clear bright violet red slightly flaked deep velvety dark red. The throat has a very large dark purple red blotch beautifully stippled at the edges with a soft creamy yellow. Upper petals have a similar blotch on each side. Each, \$1.00. Doz., \$10.00.

Beverly (1926. 79 days.) - Very fine, showy plant. Good number flowers open. Color of a beautiful violet-rose. Elegant, deep - red throat blotches. Each, 10c. Doz., \$1.00. 100, $\$ 7.50$.

Big Black (1915. 86 days.)-An extra large flower of a very pure, rich, deepred, self-color. Very rich, distinct and showy. The best, large, dark-red. Each, 10c. Doz., \$1.00. 100, \$7.50.

Black Pansy (1915. 77 days.) - Of richest dark-red. Beautiful, pansy-like throat. Extra. A general favorite. Each, 8c. Doz., 80c. $100, \$ 6.00$. 
Blue Isle (1916. 79 days.) - A good sized lilac-blue, dark-red blotches. None better in this class. Each, 25c. Doz., \$2.50.

Blue Lily (1921. 69 days.) - Light violetblue. Medium size flowers. Five and six open at a time. Graceful stem. Each, 12c. Doz., \$1.20. 100, $\$ 9.00$.

Blue Orchid (1916. 75 days.)-Rich, selfviolet blue. Black blotch with golden heart on lower petals. Extra. Each, 10c. Doz., \$1.00. 100, $\$ 7.50$.

Blushes of Cream (1929. 88 days.)-Fine height shapely plant with many (eight or more), very beautiful and refined flowers open at a time. Color one of those beautiful apricots, blushed deeper in upper throat. Lower throat a very delicate canary yellow blending into the beautiful delicate apricot, or flesh pink. Of great beauty. Must be seen to be appreciated. Each, 75c. Doz., \$7.50.

bobby (1925. 78 days.)-An immense and beautiful deep-rose with extra large and beautiful bluish-red throat blotches. First-class. Each, 20c. Doz., $\$ 2.00$. $100, \$ 15.00$.

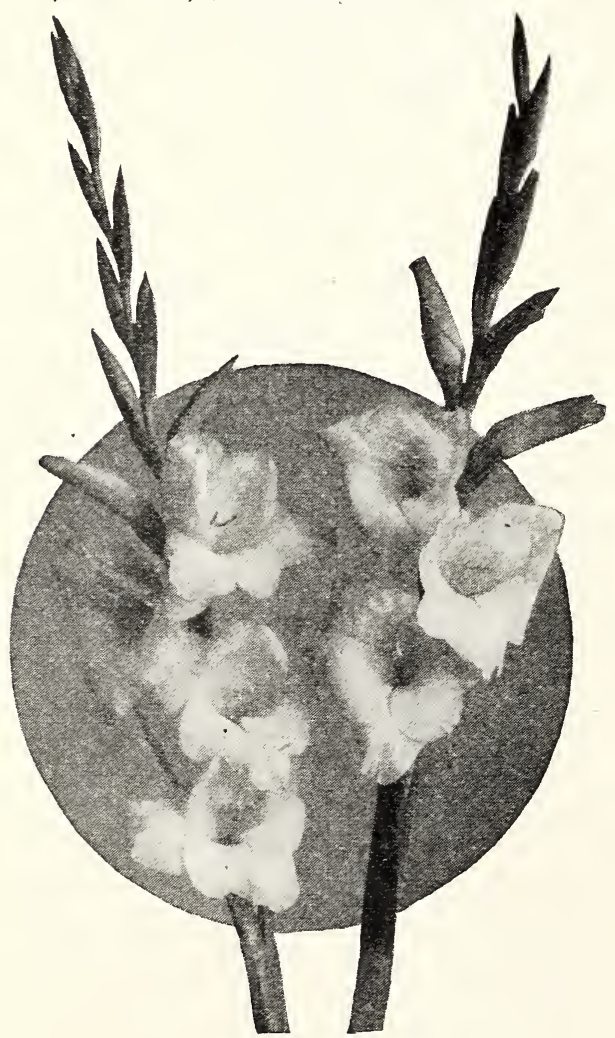

DR. J. H. NEELEY Described on Page 40
Booth Tarkington (1931)-Strong, good height plant and large flower with ample blooms open at a time. Colors bright rich Tyrian rose pink with delicate lavender purple blush. Lower petals a deeper rose pink with still darker rose red narrow central feathers or bars. A very richly colored and showy variety. Distinct and pleasing. Each, 50c. Doz., $\$ 5.00$.

Break O'Dawn (1930. 83 days.)-Very tall and stately plant. Large flowers and 5 to 7 or more open at a time. Flowers in upper petals deeply blushed white, becoming deep apple blossom pink or rose towards the ends. Inner portion of lower petals have a decidedly deeper rose pink color with very rich dark red central bars. An altogether exquisite and beautiful flower which I believe will become very popular. Each, 50c. Doz., $\$ 5.00$.

Bright Spots (1930. 74 days.) - Very tall and showy plant, 6 and more large flowers open at a time. Color a light rose red. Lower petals have very large Gloxinia like throats of very dark velvety maroon red bordered and stippled creamy white. This type usually has distinct smaller blotches or "eyes" on either or both sides of upper petals. A favorite type with the French Gladiolus Specialists. (Another very beautiful kind of this type is the variety "Emblem.") Each, 35c. Doz., \$3.50. $100, \$ 26.25$.

Brilliant Sun (1930. 86 days.)-Medium tall plant with large brilliant red purple flowers with a very dark purple red lower throat. The color and shade of it are among the most admired and popular. My collection of gladioli contains a number of similarly colored varieties, but all of them which I catalog are distinctly different. All are extra fine in artificial light. Each, 50c. Doz., $\$ 5.00$.

Buena (1928. 76 days.)-Tall, fine plant. Many large flowers, diamond form, open at a time. A fine light rose pink on a white ground, flaked a brilliant deep rose pink. Lower petals a little deeper red, beautifully penciled and with deep, velvety red central bars. A showy and pretty variety. Each, 20c. Doz., \$2.00. 100, $\$ 15.00$.

Burlington (1931) - Fine height plant and good size flower. Color a deep velvety, rose red, deeper in lower throat. Lighter in upper throat. A pretty dark rose red. Each, 35c. Doz., \$3.50. 100, $\$ 26.25$. 
Burning Bush (1930. 92 days.) - Tall, stately and fine plant. Large flowers of deepest fiery salmon rose red. A little deeper red in lower throat. A white narrow line extends from the throat featherings outwardly, well towards the ends of lower petals, giving a very distinct appearance. Of richest bright salmon red color. Very showy and a fine variety. Each, 50c. Doz., $\$ 5.00$.

Byron L. Smith (1917. 76 days.)-One of the very best. Most refined lavenderpink on white ground. Exceedingly fine as a cut flower. Color equal to a very choice cattleya orchid. Winner of many awards. Illustrated on inside front cover. Each, 10c. Doz., \$1.00. 100, \$7.50.

Capt. B. B. Lipsner (1930. 75 days.)Fine height plant and showy flowers. Flowers good size and very bright fiery rose pink much lighter in upper throat and much deeper on ends of petals and still deeper on lower petals. Inner half of lower petals have beautiful deep rose red throat blotches edged a lighter rose, sometimes edged a very delicate soft tone of cream. A very unusual and showy variety. Each, 50c. Doz., \$5.00.

Cardinal Prince (1924. 69 days.) - A magnificent self-colored cardinal. Flowers large and of splendid form and placement, six to eight open at a time. A good, tall plant. An A-1 cardinal, far superior to any other variety in this color. Destined to become very popular. Each, 15c. Doz., \$1.50. 100, $\$ 11.25$.

Carmine Rose (1928. 84 days.)-Good height plant. Fine plant with good sized flowers and plenty open at a time. Color a fine shade of carmine rose, deeper on lower petals. A very good gladiolus in this color. Each, 12c. Doz., \$1.20. 100, $\$ 9.00$.

C. C. Sherlock (1928. 69 days.)-Fine shapely plant with ample good sized flowers open at a time. Flowers of purest deep salmon red imaginable. A deeper toning on outer portions. Throat a little lighter with fine central bars on all the petals. Throat on lower petals has beautiful pure selfcolored blotches of soft canary yellow perfectly blended with the salmon red main color. Each, 35c. Doz., \$3.50. 100, $\$ 26.25$.

C. E. Stout (1931) - Fine height and neat plant with five or more large flowers open at a time. Color of richest deep American Beauty rose pink all over the entire flower. Lower petals have much deeper rose red central bars on a deep rose red throat. This is a

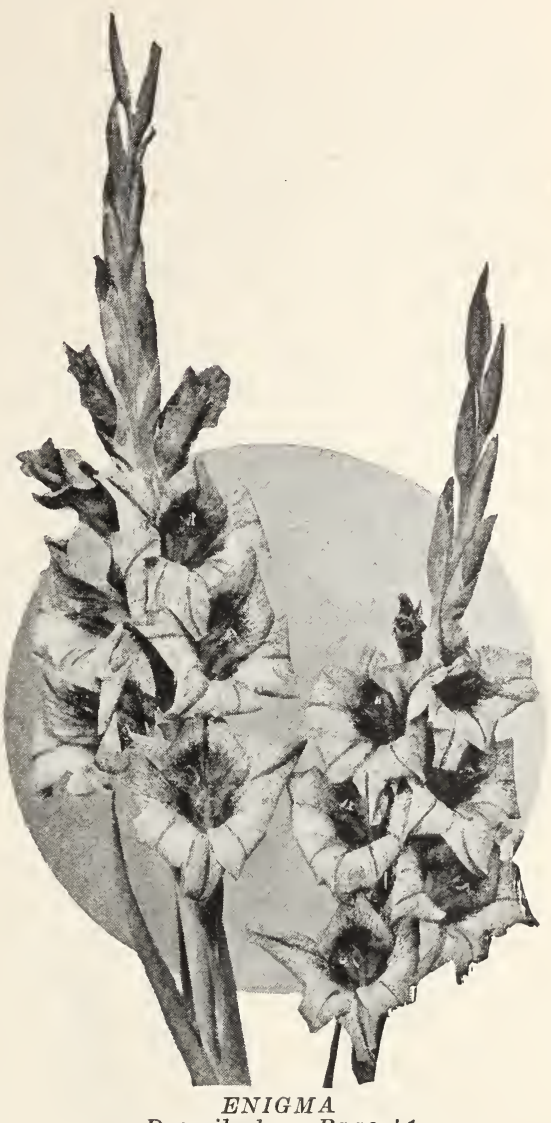

Described on Page 41

very distinct and striking flower of great beauty, and I believe destined to become one of the very best for all purposes. Each, \$1.00. Doz., \$10.00.

Challenger (1915. 88 days.)-Very large and vigorous plant. Giant, dark, rich, velvety-red, solid color. An extraordinary fine variety. Each, 8c. Doz., 80c. $100, \$ 6.00$.

Chantry (1931) - Fine medium height plant and good size flowers of a deep peach blossom rose pink color. Lower petals have a beautiful pure rose red blotch. All the petals have a fine soft, blush white, narrow border line, beautifully blended. A beautiful variety. Each, 50c. Doz., $\$ 5.00$.

Charles F. Fairbanks (1925. 82 days.)Another red, but a distinct and beautiful variety named in honor of a recent President of the American Gladiolus Society. I have worked up a good-sized stock of this variety, believing it will be in big demand as soon as brought to 
public attention. Each, 10c. Doz., $\$ 1.00$. $100, \$ 7.50$.

Cheerio (1930. 98 days.)-Medium tall, fine plant and quite large flowers of richest salmon red. Throat of brightest orange red deeper in the centers. Lower petals especially large, giving the flowers a widely opened and rounded form. A very showy, distinct and beautiful variety. Each, 50c. Doz., $\$ 5.00$.

Cherry Rose (Quartinianus Hybrid) (1927. 83 days.)-Tall, strong plant and spike. Flowers wide open. Rich cherry-rose color. Central portion of lower petals have beautiful penciled feathers. Feathers barred deeper rosered interspersed with white on a creamy ground. The entire flower is distinct and of pleasing appearance. Well worthy of the space in every garden. Each, 20c. Doz., \$2.00. 100, \$15.00.

Circe (1916. 73 days.) - Very early, tall, deep dark-red. A large, extra fine, dark

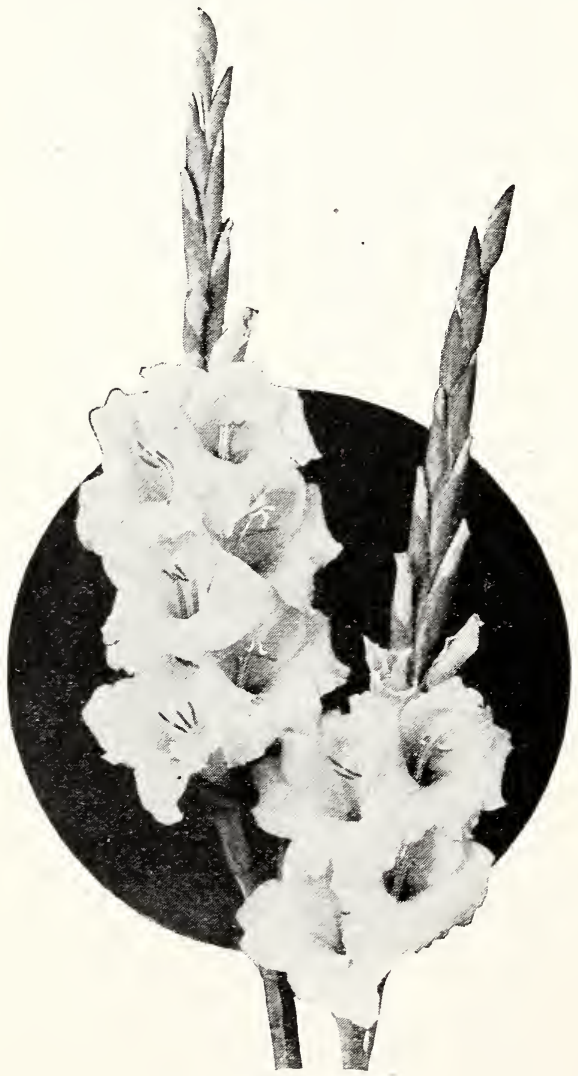

FAIREST PEARL

Dcscribed on Page 41 flower. Each, 10c. Doz., \$1.00. 100, $\$ 7.50$.

Clarise (1930. 77 days.)-Tall, graceful plant with giant flowers. Purest deep flesh or salmon pink over entire flower excepting inner portion of lower petals which is a soft creamy yellow overlaid with very faint pencilings and tracings of delicate salmon pink. Extraordinary showy and beautiful appearance. Refined and delicate coloring. Extra grand. Each, \$1.00. Doz., \$10.00.

Claude Bowers (1930. 96 days.)-Medium tall, fine plant. Large beautifully placed flowers and $6-8$ or more open at a time. Color of most beautiful pure rose red, a little deeper on lower petals with almost no throat markings, giving an almost perfect self-color effect. The inner upper throat is much lighter rose pink giving a remarkable effect from a straight front view, or when-tilted a little backwards. The flower tilted forwards at an angle of $45^{\circ}$ is of a perfect self-color, unsurpassed in color by any red rose. Very, very beautiful and distinct. Each, 75c. Doz., \$7.50.

Col. Chas. Lindbergh (1928. 76 days.)Tall, stately plant. Flowers large and widely open, and of a beautiful, broad butterfly form. Many open at a time and perfectly arranged on spike. A refined rose with fine lavender tint on a white ground on upper petals. Lower petals covered two-thirds with soft, pastel creamy yellow. Very finely and beautifully stippled and central bars of fine cream color extending beyond the blotches. Ends of lower petals of same Cattleya rose color as the upper petals. A very extra and high class variety. One of the most distinct and beautiful gladioli ever produced. Each, 75c. Doz., $\$ 7.50$.

Color Beauty (1930. 83 days.) - Tall, graceful plant with eight or more medium sized flowers open at a time. Color deep Tyrian rose red flaked deeper. Outer portion of lower petals intense fiery velvety dark rose red. Upper throat much lighter. Base of throat feathered beautifully and penciled tyrian rose on a white ground. Central bars of velvety tyrian red-an all around beautiful and showy variety of most elegant and beautiful appearance. Exceedingly rich, showy and striking color. May fairly be called a color beauty. Each, 75c. Doz., \$7.50.

Colors (1928. 77 days.) - Tall, fine plant and large flowers of deep rose pink or red. Very large and showy. Beautiful deep velvety red throat blotches "like a Gloxinia" bordered with a soft yel- 
low which is beautifully stippled. Each, 35c. Doz., \$3.50. 100, \$26.25.

Coming Joy (1931)-Tall, stately plant. Flowers most brilliant orange scarlet. Lower petals have a beautiful deep, orange red blotch with blackish maroon red lines. Beautifully feathered center towards the base terminated by clear white center lines. A very showy and striking flower. Each, 50c. Doz., $\$ 5.00$.

Contrasta (1931) - Fine height plant with plenty of good size flowers open at a time. Color a rich rose. Upper inner throat has bluish cast and lower petals dark velvety blue central bars on deepest rich velvety red ground, covering entire petals. The lower petals are beautifully ruffled while the upper three petals are plain. A very unusual combination and a very pretty red variety. Each, 50c. Doz., \$5.00.

Cream Cups (1931) - Fine large plant and flower. Color a pure soft creamwhite, delicately blushed over outer portion of all petals. Throat on lower portion of delicate light canary yellow. All three colors, or tints, so perfectly blended as to give the flower a decidedly rich pastel effect. An exceedingly refined and beautiful flower. Each, 75c. Doz., \$7.50.

Cream Puff (1930. 84 days.) - Fine plant of medium height with five or more very shapely large flowers open at a time and facing very beautifully. Color upper petals a delicate creamy buff. Lower petals have a large distinct and vivid blotch of deep red, bordered finely by a deep golden buff, extending well out on the petals, shading to a lighter tone towards the petals' ends, very striking and showy. Each, 50c. Doz., $\$ 5.00$.

Dainty Lily (1931)-Tall stately plant with six or more large flowers open at a time. Color soft flesh pink flaked deeper on outer portion of all the petals. Throat in lower portion of a rich soft canary or lemon yellow, toning out to a very delicate blushed cream pink toward the ends of petals. A beautiful flower of refined pastel color combination, very pleasing. Each, 50c. Doz., \$5.00.

Darling O'Mine (1930. 81 days.)-Fine height and shapely plant. Large flowers widely expanded and perfectly placed. Color delicate salmon pink, deepening towards the ends of the petals. Lower petals have large throat blotches of deep red in the center lightening to a glowing orange red. A dis-

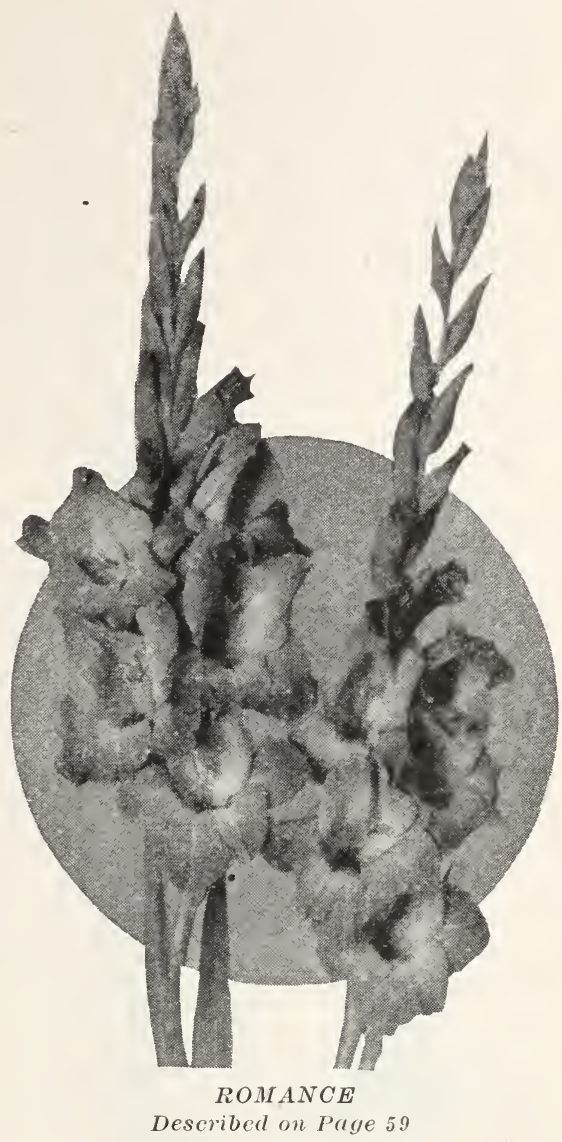

tinct and most remarkably beautiful variety. Each, 75c. Doz., \$7.50.

Delicacy (1928. 79 days.)-A tall, fine plant with a very beautiful and delicate deep rose pink flower. Large and wide open. Throat white very delicately blended with pink. Fine florists' flower and fine for every purpose. Each, 15c. Doz., \$1.50. 100, \$11.25.

Dew of Heaven (1930. 96 days.)-Very tall and stately plant. Flowers large and showy. Color of a rich deep rose pink with a tyrian rose tone which is hard to describe. Throat has a beautiful tyrian rose red blotch with fine central bars of white dividing the same giving a beautiful effect. An elegant and distinct variety. Each, 50c. Doz., $\$ 5.00$.

Dixie Girl (1931)—Good height and fine plant. Color a fiery deep peach blossom rose pink. Large deep rose pink throat with very dark rose red median 
lines on the lower petals. A brilliant peach blossom rose pink with very beautiful opening buds. Must be seen to realize its beauty. Very extra. Each, \$1.00. Doz., \$10.00.

Dominus (1929. 69 days.)-Tall, fine, shapely plant with seven and more perfect blooms, all facing one way, open at a time. Color is hard to describe. It is of a very deep dark red yet not of a blackish shade. Beautiful still darker throat blotches with a slight white line extending a little beyond all the blotches. A velvety finish over all and in all respects an exceedingly distinct and showy variety. Scarce. Each, 75c. Doz., \$7.50.

Dorothy Dick (1931) - Tall, fine plant, plenty large flowers open at a time. Color of richest deep salmon red with large clean white throat daintily tinted cream. Extra choice and fine. A beautiful variety in every way. Each, 75c. Doz., \$7.50.

Dr. David Griffith (1929. 77 days.)Quite tall and stately plant. Flowers

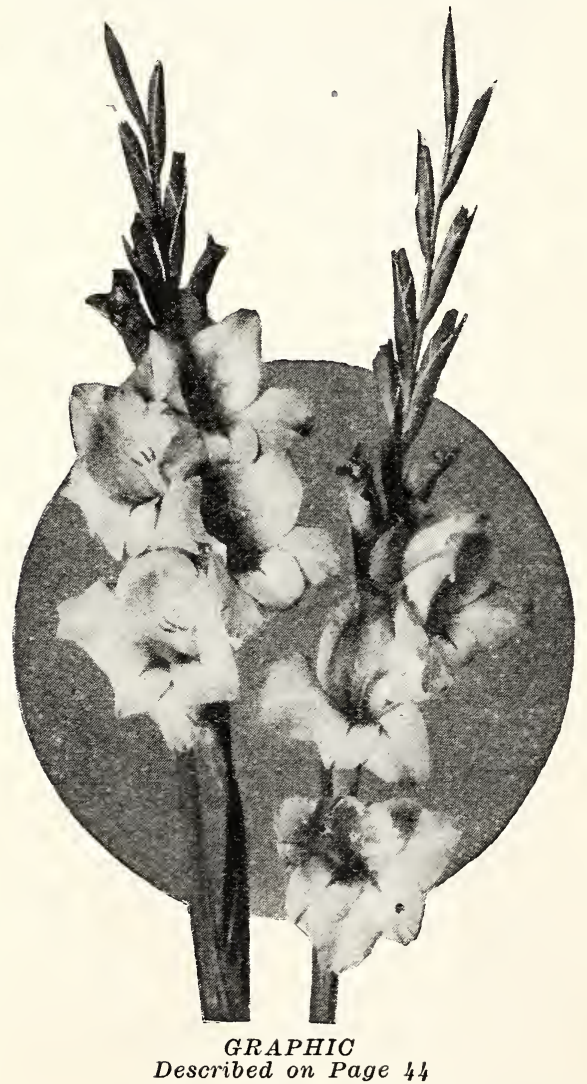

of very remarkable form. Tubular and as upright as a tuberose or a crocus. An altogether unusual type and exceptionally attractive. Color is a beautifully slight lavender blush of pink over all six petals. Throat a little deeper blushed. And back of neck of the flower is a deep rose pink giving a very striking effect. All six petals of same coloring rarely showing the slightest of marking. A unique and remarkable form. Showy and beautiful. (No crocus is as beautiful.) Each, $\$ 2.00$. Doz., $\$ 20.00$.

Dream Flower (1928. 85 days.)-Tall, sturdy plant, very large flowers and many open at a time. An "America" seedling of very imposing appearance. Entire flower has a very beautiful shade of pure, soft pink a little deeper than "America" and throat blotches deeper and showier than "America." A very extra florists' flower and a magnificent bedding variety. Each, 75c. Doz., $\$ 7.50$.

Dr. Elkins (1922. 81 days.) - A true sport from "Mrs. Frank Pendleton." Same large and showy flower, but the original rose-pink has changed to a white and the large throat blotches to a fine shade of lilac-blue. A distinct and classy flower and a decided acquisition. Each, 12c. Doz., $\$ 1.20$. 100, $\$ 9.00$.

Dr. J. H. Neeley (1923. 76 days.)-Tall, massive plant. Very large and refined flower of finest blushed white. Throat clear and clean, pure, soft white, tinted softest light canary-yellow or cream. A grand variety. Illustrated on page 36. Each, 10c. Doz., \$1.00. $100, \$ 7.50$.

Duchess (1926. 89 days.)-Late midseason. Fine plant and spike. Flowers of a fine shade of light watermelon-red with darker red in throat. Fine. Each, 8c. Doz., 80c. 100, $\$ 6.00$.

Ed Springer (1926. 83 days.)-Strong, fine plant, showy flowers of light lavender rose-pink. Outer edges of petals are a stronger rose-pink color, somewhat flaked. Lower petals have fine rose-red markings bordered and tinted white. Each, 20c. Doz., \$2.00. 100, $\$ 15.00$.

Eighth Wonder (Quartinianus Hybrid) (1927. 89 days.)-Deep, smoky oldrose with a lighter undertone. Lower petals of same color but delicately mottled and flaked with central lines of red. Very large plant with many large blooms open at a time. Each, 50c. Doz., $\$ 5.00$. 
Elkhart (1917. 83 days.)-Violet purple, deeper throat blotch. An exceedingly fine variety. Very rich in color. Each, $\$ 1.00$. Doz., \$10.00.

Emblem (1928. 77 days.)-Fine plant and large flowers, six or more open at a time. This is a very unusual, extraordinary and beautiful variety. It is as wonderfully marked as a magnificent Gloxinia. In color a rich cherry red with a very remarkable throat coloring which runs over all six petals. On the lower three it covers first a large, dark, velvety, ruby red blotch wonderfully bordered by two distinct additional color zones. First a very dark, deep red about one-fourth inch wide. This is bordered again by soft yellow, very beautifully striped with red. A wonderful and showy flower in every way. Each, 75c. Doz., $\$ 7.50$.

Enigma (1921. 76 days.)-Tall plant with large flowers. Strikingly striped red, white and blue. Is all that the name implies. Illustrated on page 37. Each, 12c. Doz., \$1.20. 100, \$9.00.

Estella (1916. 75 days.)-One of the largest gladioli. Fine, deep rose-pink Mammoth and beautiful. Each, 10c. Doz., $\$ 1.00$.

E. T. Barnes (1931)-Tall, strong fine plant. Very large flowers of a beautiful form and perfectly placed. Center of lower petals has a deeper darker red feather. Color a deep rich dark rose red. A very fine showy dark rose red. Distinct and pleasing for all purposes. Each, 50c. Doz., \$5.00.

Evening Glow (1930. 77 days.)-Tall strong vigorous plant with large massive flowers. 5 to 7 or more, open at a time. Color very dark cardinal maroon red all over, excepting a deeper flaking around entire flower and lower petals have a much darker throat which in turn has beautiful narrow white lines extending one-half way the length of the petals. A very showy and distinct variety, richly colored. Each, 50c. Doz., \$5.00.

Excellence (1927. 69 days.)-Large, fine grower. Blooms large, and a good number open at a time. Color a deep orange-vermilion. Self-color in effect but faint throat mark of slightly deeper shade. Strong, round, open flowers with large lower petals. Conspicuous and very attractive. Each, 20c. Doz., $\$ 2.00$. 100, $\$ 15.00$.

Fairest Pearl (1930. 103 days.)-Medium tall, strong elegant plant with six

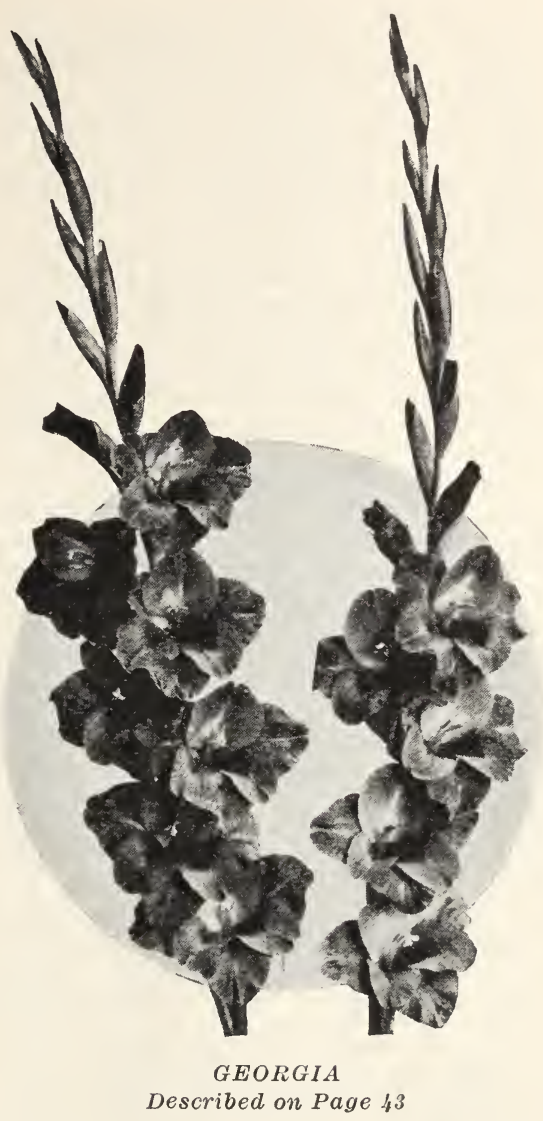

or more large blooms open at a time. A beautiful white of a delicate creamy tint and faintest soft yellow on lower petals, almost white, and no flaking nor other markings. Splendid substance and of ideal form. Perfect placement. An extra choice tinted white. Illustrated on page 38. Each, $\$ 3.00$. Doz., $\$ 30.00$.

Fairest White (1918. 79 days.)-Purest white, softest pink throat lines. Ethereally beautiful. Illustrated on inside back cover. Each, 8c. Doz., 80c. $100, \$ 6.00$.

Fairfield (1916. 70 days.)-Tall, vigorous. Giant flower. Very symmetrical. Beautiful dark maroon color. A first prize variety at the A.G.S. show, Rochester, Aug., 1925. Each, 8c. Doz., 80c. 100, $\$ 6.00$.

Fairmont (1929. 85 days.)-Tall, slender plant with beautiful butterfly like flower of a bright deep tyrian rose red color. Lower petals in throat deep 
dark red with velvety blackish red central bars with a sheen approaching delicate bronze towards throat. Upper throat portion nearly white, beautifully veined. Entire back of flowers a pure self rose red. Tall stately striking variety. Each, 35c. Doz., \$3.50. $100, \$ 26.25$.

Fairview (1928. 77 days.)-Many large flowers open at a time. Petals colored deeper towards the outer ends. Throat blotches, on lower petals, of deep, velvety red with deeper central bars. Edges of blotches beautifully stippled, giving a very rich pansy-like effect. Very choice and showy. Each, 25c. Doz., \$2.50. 100, \$18.75.

Fawn Gold (1929. 66 days.) -Tall, strong and perfect plant. Very large flowers and six or more open at a time, beautifully placed but not crowded. Color deep rich fawn to light golden. Large and very striking pale red blotches on lower petals with deeper red central bars extending beyond the showy blotches. Edges of blotches also a deeper red blended into a rich yellow. A magnificent variety in every way. Each, 35c. Doz., \$3.50. 100, \$26.25.

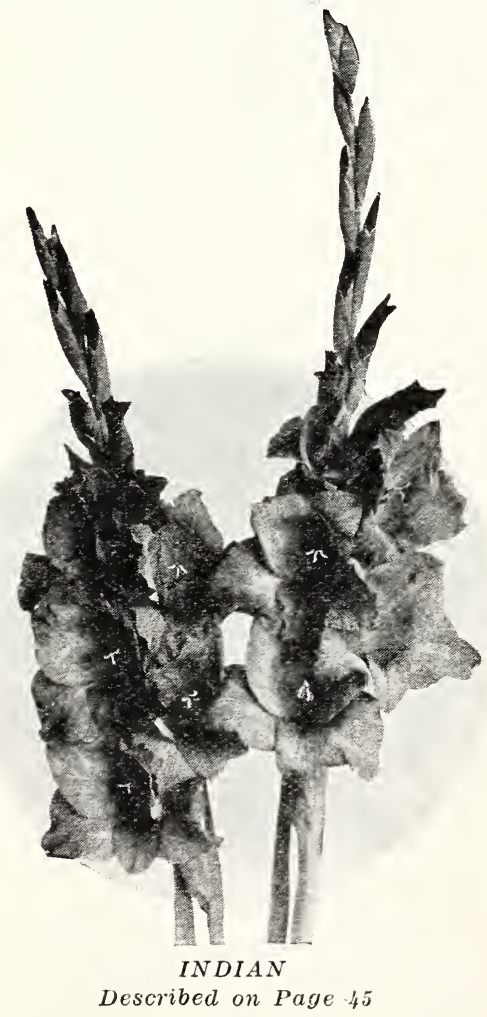

Fiancee (1930. 83 days.) - Fairly tall medium-sized flowers. Six and more open at a time and exceedingly striking and showy. Color a creamy white with an exceedingly large and very beautiful deep velvety red blotch covering most of the lower petals. The center of these blotches is a little lighter red finely blended with the deeper dark red edges of the blotches. Perhaps no richer blotched variety in existence. Each, 50c. Doz., \$5.00.

Fire Glow (1929. 72 days.)-Tall stately plant. Flowers of good size and of most intense vivid glowing scarlet. Almost a pure "self." Exceedingly brilliant and showy. Each, 50c. Doz., $\$ 5.00$.

Fire Pink (1929. 80 days.)-Tall fine plant with six or more very beautiful deep salmon red blooms open at a time. Of richest glowing deepest salmon red, purest self color over entire flowers. One of the very grandest of all. Scarce. Each, 50c. Doz., \$5.00.

Fire Ribbon (1915. 67 days.)-Tall, with many blooms open at a time. The spike is a long, fiery band of glowing red. Exceedingly rich and strikingly showy. Each 8c. Doz., 80c. 100, \$6.00.

Fire Torch (1929. 69 days.)-Quite tall but very slender plant. Small upright flowers of the most intense fiery scarlet imaginable. Very unique and pretty. Each, 25c. Doz., \$2.50. 100, \$18.75.

Flaming Vale (1921. 74 days.) - Very tall; long spikes with large, deep, cardinal-red flowers. Throat a little deeper. Pure self-color effect. Very good. Each, 10c. Doz., \$1.00. 100, \$7.50.

Fuld's Favorite (1927. 102 days.)-Massive flowers of delicate, light lavenderrose. Lower petals of same color on outer portions with deeper rose colored throat laid on a ground color of delicate cream. Average of eight and nine flowers open at a time. Tall and strong plant. This variety was the favorite of the late Maurice Fuld, organizer of the American Gladiolus Society, and whose judgment of fine gladioli ranked high. No doubt this choice new variety will become very popular. Stock yet limited. Each, 25c. Doz., \$2.50. 100, \$18.75.

Gaiety (1915. 75 days.)-Bright salmonpink, flaked deep salmon-red. Very conspicuous pure white blotches on lower petals. Large flower and tall spikes. Exceptionally attractive. Illustrated on inside front cover. Each, 8c. Doz., 80c. 100, $\$ 6.00$.

Georgia (Kunderd's) (1926. 73 days.)Tall, fine, graceful plant and foliage. 


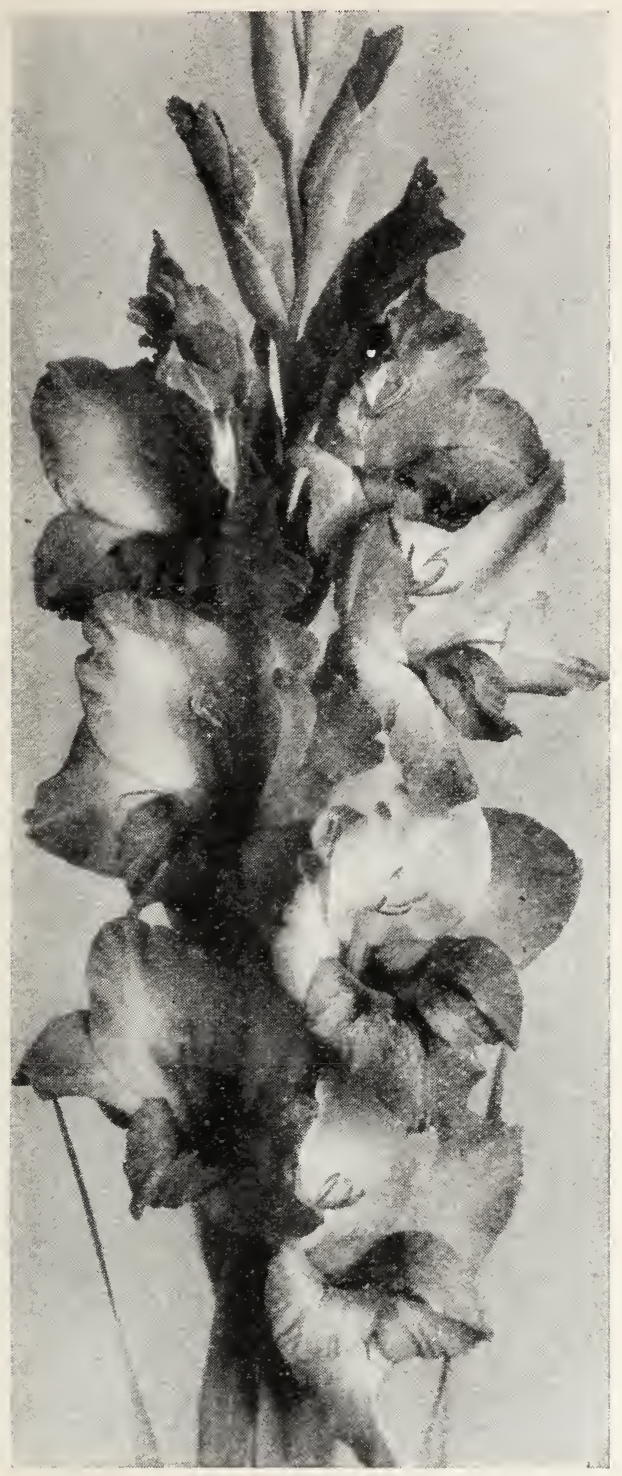

DR. NELSON SHOOK

Described on Page 23

Mrs. R. H. Rowlatt, Calif. Aug. 13, 1931.

The collection of Primulinus Hybrids which I got from you in May have just bloomed, and I am writing to tell you that the flowers were beautiful, and that they passed all expectations in spite of excessively hot weather. It was so hot that it was necessary to put up poles and spread sheets over them. I had gotten Primulinus Hybrids from you before in Vernal, Utah in 1921 and in Tientsin. China in 1923, but these flowers were much finer in every way.
Many beautifully and elegantly placed blooms open at a time. Color of bright, deep amaranth purplish-red. with elegant throat blotches of dark amaranth-red. Illustrated on page 41. Each, 20c. Doz., \$2.00. 100, \$15.00.

Glenn Banks (1930. 98 days.)-Medium tall and fine plant with 5 or more large shapely flowers open at a time. Color dark red purple with throat very much deeper, of very dark, velvety rose red, extending almost to the ends of petals. The center has darker red narrow median lines which sometimes have a slight narrow white central line. A very beautiful dark red gladiolus. Each, 35c. Doz., \$3.50. 100, \$26.25.

Gloaming (1931)-Fine height plant and large, widely expanded flowers. Color deep Tyrian rose red, lighter on upper central petal and much deeper on most of lower petals. Petals are long pointed and graceful. A fine shade of red and a beautiful flower. Each, 35c. Doz., $\$ 3.50$. 100, \$26.25.

Golden Apricot (1931)-Tall, fine plant. Flowers are deep golden fawn yellow on upper petals. Lower petals a deep orange-fawn yellow with finest central lines of orange pink. Petals long, pointed and recurved in most artistic lily-like form a most artistic and beautiful appearance. Very rich color and unusual. Each, 25c. Doz., \$2.50. 100, \$18.75.

Golden Fringe (1928. 88 days.)-Tall and vigorous plant. Flowers large and of a soft orange on upper petals. Lower petals orange red in throat and outer portion blending to a lighter orange red. All lower petals are delicately bordered with a narrow golden yellow fringe. Very striking, unusual and beautiful. Each, 25c. Doz., \$2.50. $100, \$ 18.75$.

Golden Rose (1930. 88 days.)-Tall stately plant and a large showy flower of delicate old rose color flaked deeper rose on outer portion. Throat very beautifully feathered pink on a large widely deep canary yellow base. A fine deeper yellow median line extends almost out to ends of lower petals. A very distinct gladiolus. Each, 35c. Doz., \$3.50. 100, \$26.25.

Gordon L. Pirie (1931) - Tall, stately plant ample and magnificent large flowers. Color as pure a self red as can be imagined of almost the same color as the "President Canna." I do not believe there is another as rich and glowing red glad as this one, and I believe it will create a sensation wherever seen. Each, $\$ 1.00$. Doz., $\$ 10.00$. 
Gorgeous (1929. 80 days.)-Fine good height plant. Large rich rose-red flowers having a very vivid deep dark red velvet-like throat blotch, as rich as the blotch in "Pendleton." Noricher throat blotch in any variety. Extra grand and showy. Each, 75c. Doz., $\$ 7.50$.

Goshen (1923. 83 days.)-A fine Pendleton seedling of medium deep silvery rose-pink color. Large, showy rose-red blotches. Very good. Each, 10c. Doz., $\$ 1.00$. 100, $\$ 7.50$.

Gov. Emmerson (1930. 68 days.)-Tall strong plant and massive flower of a deep vermilion orange, flaked faintly with a deep orange red. Outer ends of lower petals a deeper shade of same color, but the lower throat is entirely covered by pure deep dark rose red. An outstanding beauty, very showy and massive. Each, 75c. Doz., \$7.50.

Gov. Hanly (1915. 65 days.)-Tall, showy, early, rich cardinal-red, with deeper throat color. First-class bedding and cut-flower variety. Illustrated

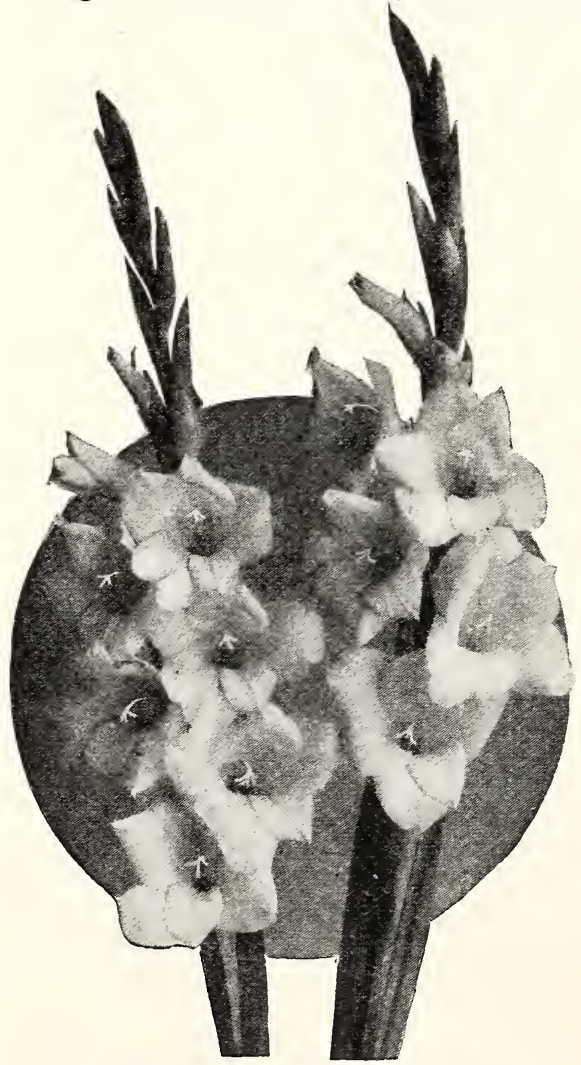

KUNDERD'S YELLOW FAVORITE Described on Page 47 on page 59. Each, 8c. Doz., 80c. 100, $\$ 6.00$.

Graf Zeppelin (1930. 73 days.)-Extra tall and stately plant with many large widely expanded blooms open at a time. Flowers are uniformly and perfectly placed on the spike. Large round flowers with extra strong lower petal development. Color of fine pure soft rose pink, deepening towards outer ends of all six petals. Lighter soft rose pink towards inner portion. Lower petals have a delicate light rose red inner throat marking extending outwards to a delicate white. Each, $\$ 1.00$. Doz., $\$ \mathbf{1 0 . 0 0}$.

Grand Glory (1928. 79 days.) - Very tall giant plant and massive flowers. Petals a golden orange with a beautiful yellow throat. Both colors perfectly blended together. An immense and showy variety. Magnificent. Each, 75c. Doz., \$7.50.

Graphic (1928. 67 days.)-Good height. Very large flowers of outstanding and distinct appearance. Soft, deep, mellow purple or deep tyrian pink. Blotches on lower petals a fine deep rhodamine purple red. A very attractive and showy flower. Illustrated on page 40. Each, 15c. Doz., \$1.50. 100, $\$ 11.25$.

Haughty (1930. 80 days.)-Medium tall, fine plant. Flowers very large and massive. Color rich deep rose red. A little deeper on outer edges of the petals, but so subdued in tone as to be almost unnoticeable, might almost be termed a self-color. Magnificent and beautiful. Each, 35c. Doz., \$3.50. 100, $\$ 26.25$.

Helen Keller (1930. 79 days.)-Medium tall fine plant. Five or more large flowers open at a time. Color a clear rose pink, moderately flaked deep orange rose towards outer edges of the petals. Lower petals have large wide beautifully feathered soft rose red blotches. Beautiful opening buds. Charmingly effective and pleasing flower. Each, 75c. Doz., \$7.50.

Herald (1928. 97 days.)-Tall, graceful plant and large and very showy flowers of a decided deep, rich rose red. Upper throat a little lighter. Lower petals and throat much deeper dark velvety red. A very showy and beautiful variety. Each, 25c. Doz., \$2.50. $100, \$ 18.75$.

Herbert Hoover (1929. 74 days.)-Fine good height plant with plenty good sized bright deep cherry-rose red blooms open at a time. Large throat blotches, of deep blackish crimson becoming almost scarlet at the upper 
edge, gives same striking effect that "Mrs. Frank Pendleton" does. A very beautiful variety. Each, 50c. Doz., $\$ 5.00$.

H. H. Goldstein (1931) - Tall showy plant with six to eight and more giant flowers open at a time. Color, soft old rose with a tint of blue, lightly flaked rose red and back of flowers dark violet rose red at base. Lower petals have very large orchid or pansy like blotches of deep rose purple blue edged beautifully with creamy blue which again is edged with a faint line of violet rose. A narrow short central line of white still further enhances the striking appearance of this remarkable show and garden variety. A magnificent show variety which cannot be described nor its remarkable appearance realized without seeing it in bloom. Each, $\$ 1.00$. Doz., \$10.00.

H. H. Groff (1930. 67 days.) - Tall showy plant with 6 or more perfectly placed flowers of magnificent purest deep self salmon red color. Lower petals same color with beautifully feathered lavender white on inner portion. I consider this variety unsurpassed in any color and have named it in honor of Mr. H. H. Groff of Canada, to whom the Gladiolus world owes a great debt of gratitude. Each, $\$ 1.00$. Doz., $\$ 10.00$.

Highland Laddie (1925. 85 days.)Large, massive and beautiful pink of a decided and pleasing shade. A very choice kind and a rapid multiplier. Each, 10c. Doz., \$1.00. 100, \$7.50.

Holy Grail (1930. 83 days.) - Very tall plant with elegant foliage and flowers usually cupped and upright. Color almost same as the famous variety "America" only a little more lavender tinted. Lower petal, usually only one, also has the marking of "America" edged at ends a delicate cream. Very unusual. Large flowers and stately spike and six or more flowers open at a time. Each, 50c. Doz., \$5.00.

Hugo Eckener (1930. 88 days.)-Very tall plant and very large and massive flower, beautifully formed and perfectly placed on the spike. Color a bright blood red, a little lighter in upper portion of throat. Lower portion of throat deeper blood red down center of petals with full width of petals a wide fiery orange vermilion. A magnificent and gorgeous flower. Each, 75c. Doz., $\$ 7.50$.

Ida Van (1915. 76 days.) -A most beautiful, deep salmon-red, or flaming

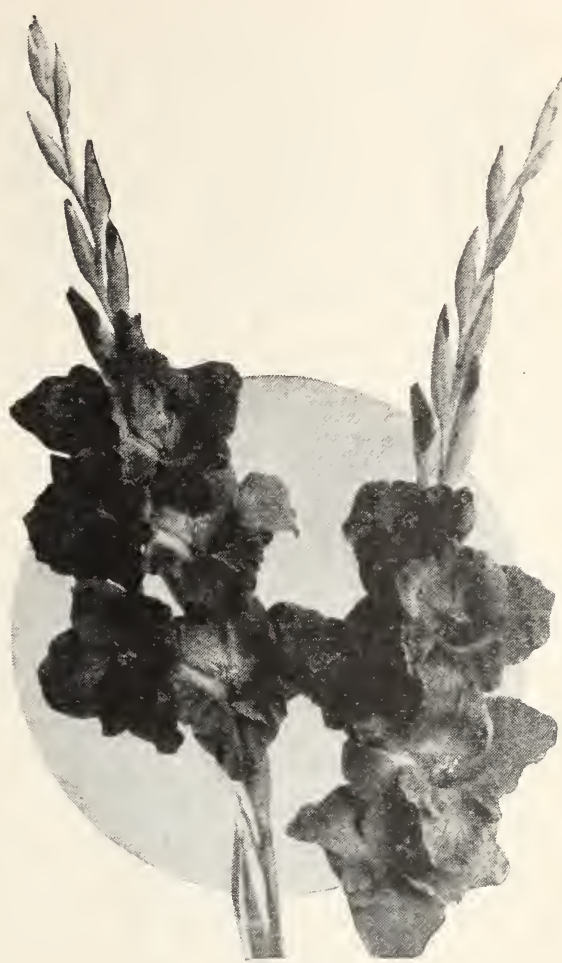

SPLENDORA

Described on Page 62

orange-pink. Very rich and brilliant color. Highest award at Cleveland, and certificate of merit. Each, 8c. Doz., 80c. $100, \$ 6.00$.

Immensity (1921. 92 days.)-Tall, strong plant. Bright salmon color. Very large flowers and many open at a time. Very choice. Won first prize as best American production two years in succession at the Mid-western Gladiolus Show, Des Moines, 1924 and 1925. Each, 12c. Doz., $\$ 1.20$. 100, $\$ 9.00$.

Imperium (1928. 96 days.)-Extra strong and tall, fine plant. Flowers very large and widely open. Color fine, deep rose pink or light cherry red. Lower petals deeper bright red and have an extra fine bluish red central bar. A perfect and a very beautiful variety. Each, 20c. Doz., \$2.00. 100, $\$ 15.00$.

Indian (1921. 71 days.)-Strong plant, large, well expanded flowers. Many open at a time. Color of deep aniline or Indian-red. Illustrated on page 42. Each, 10c. Doz., \$1.00. 100, $\$ 7.50$. 
Indian Chief (Quartinianus Hybrid) 1927. 84 days.)-Deep-red with bluishpurple tint. Lower petals deeper with still deeper dark-red median lines blended at the edges a clear red. An exquisitely beautiful, late red variety. Each, 25c. Doz., \$2.50. 100, \$18.75.

Intramura (1928. 86 days.) - A strong, splendid plant with many large, beautiful flowers open at a time. Color almost exactly "America" over again. Perhaps better and has a good deal better plant. Very choice and fine. Each, 25c. Doz., \$2.50. 100, \$18.75.

Iroquois (1929. 70 days.)-Fine medium height and shapely plant. Ample blooms open at a time. Color of deepest dark ruby red. Throat much deeper, almost a black dahlia red. Entire flower over back and face of flowers a very glowing velvety sheen. One of the richest and showiest deep velvety reds imaginable. A striking variety. Each, \$1.00. Doz., \$10.00.

I Excel (1916. 80 days.)-Very tall.

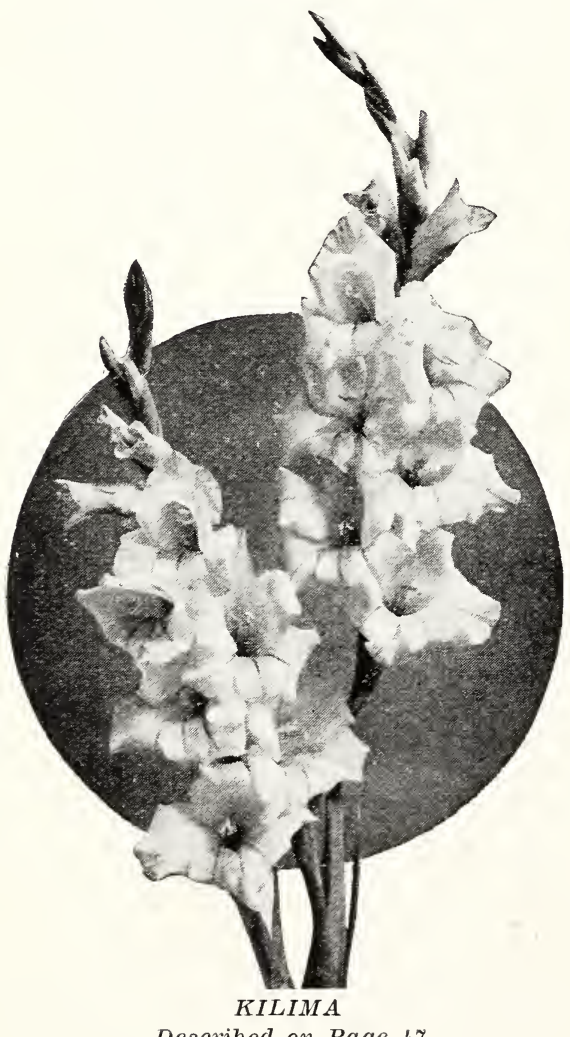

Described on Page 47
Large flower. Bright, light rose-red. Many open. Magnificent throat. Each, 8c. Doz., 80c. $100, \$ 6.00$.

Jacelia (1929. 71 days.)-Good height and shapely plant with eight or more perfectly placed blooms open at a time with all facing perfectly one way. Color glowing deep rose pink lighter in upper throat, lower petals deeper bright rose red and clearly bordered with narrow white edge. A distinct richly colored flower. Each, 50c. Doz., \$5.00.

James M. Sheldon (1931) - Extremely tall plant and foliage and giant wide flowers, spread like a mammoth red butterfly. Color a glowing velvety scarlet with a fine narrow gold bar halfway down lower central petals. Also fine large lower throat blotches delicately mottled with the red and yellow colors combined. Extremely. large, stately and showy flowers in every way, and extra grand. One of the most wonderful and distinct of all reds. A remarkable flower. Each, \$1.00. Doz., \$10.00.

J. F. Rosenfield (1931)-Tall graceful plant with six to eight large, widely expanded flowers open at a time and color a blushed cream with lower petals nearly covered a fine shade of canary yellow, outer ends of lower petals same color as upper petals. Buds show a beautiful blending of soft yellow and flesh. Named in honor of my friend, Mr. J. F. Rosenfield, who has originated some of our finest Peonies. Each, 50c. Doz., \$5.00.

J. Harry Selz (1931)-Fine tall graceful plant and very large flower. Color bright deep velvety dark maroon red. Lower petals almost covered, much deeper dark red, with only slight white markings near base of throat. A very large and showy variety. Each, 50c. Doz., \$5.00.

J. Horace McFarland (1927. 88 days.) -Extra tall, vigorous plant. Very large flowers approaching golden ophelia rose-color. Lower petals pure, deep canary-yellow. Some of the petals will occasionally be orange-red, but the whole effect is as described above. At a slight distance the effect of these colors is remarkable. Sure to become a great favorite. Named in honor of one of America's foremost horticulturists. Each, 50c. Doz., \$5.00.

J. J. Mitchell (1926. 80 days.)-Very tall, graceful spike and plant. Large blooms of fine salmon rose-pink. Finely marked throat. Each, 10c. Doz., \$1.00. 100, $\$ 7.50$. 
John Dunbar (1923. 77 days.) - A red of very striking beauty and appearance. Intense and velvety red color with a sort of dark coppery bronze sheen, difficult to describe. Sometimes give a bent spike, which in a fine variety is very decorative. Each, 8c. Doz., 80c. $100, \$ 6.00$.

John T. McCutcheon (1925. 73 days.)A giant wonder red, something like "Bobby," yet decidedly different and beautiful. Named for the great cartoonist. Each, 15c. Doz., \$1.50. 100, $\$ 11.25$.

John T. Pirie (1922. 87 days.)-An exceptionally colored variety and very beautiful. A sort of mahogany-brown with remarkable yellow bordered dark mahogany-brown throat. In a class by itself and should be in every collection. Illustrated on inside front cover. Each, 25c. Doz., \$2.50.

Joseph J. Lane (1928. 72 days.) -Slender, graceful plant. Flower of richest, showy, deep tyrian rose red. Fine central bars of deeper velvety tyrian red. Of the popular color of "Mrs. Geo. W. Moulton." A very pleasing and fine gladiolus. Beautiful. Each, 15c. Doz., $\$ 1.50$. 100, $\$ 11.25$.

June Moth (1930. 88 days.)-Fine height plant with broadly expanded wide open flowers of Nanceianus or Butterfly form. Color, rose red on upper petals and ends of lower ones. Lower petals have very large dark rose red blotches the full width, extending well towards outer ends. The outer ends of the lower petals for a little over onefourth of an inch are of same color as the upper petals. A fine and showy variety. Each, 35c. Doz., \$3.50. 100, $\$ 26.25$.

June Night (1931)-Medium height plant with graceful slender spike. Flowers widely expanded with upper central petal well upright form. Upper petals white delicately blushed deeper on back of the flowers. Lower petals across entire petals on inner half of clearest light canary yellow, blending towards the ends to a delicate creamy white. One of those very delicately colored flowers which can only be appreciated by sight. A very delicately colored and beautiful Gladiolus. Each, 50c. Doz., $\$ 5.00$.

Kilima (1918. 80 days.)-Tall, slender plant. Beautiful creamy salmon blush. Very elegant. Illustrated on page 46. Each, 8c. Doz., 80c. 100, $\$ 6.00$.

Kunderd's Yellow Favorite (1927. 74 days.) -Rich, deep, yellowish-fawn on back of petals. Entire face of flower deep-yellow with deeper yellow on

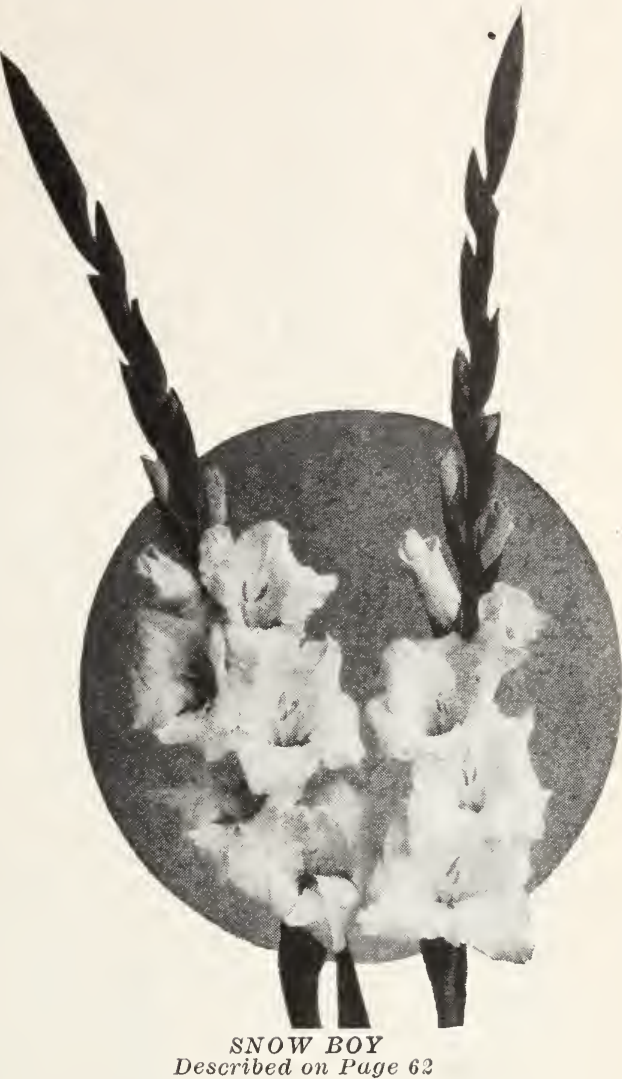

lower petals. Throat finely feathered and penciled soft-red. The plant is tall and stately. Excellent variety. Illustrated on page 44. Each, 20c. Doz., $\$ 2.00$. 100, $\$ 15.00$.

Kunderd's Yellow Wonder (1926. 72 days.)-Tall, vigorous plant and a very rapid multiplier. Flower large and seven to eight open. Almost buttercup-yellow, slightly deeper in throat, without the least marking. Has every point of a perfect gladiolus and is the finest yellow yet produced. This variety won first prize in two classes as the best yellow, also a basket of this variety together with a basket each of Dr. Nelson Shook, Sweet Rose, Tiger and Helga was awarded the Executive Committee's Silver Cup at the A. G. S. show, 1926. Illustrated on front cover. Each, 35c. Doz., $\$ 3.50$.

Lavender America (1915. 68 days.)-A very large, beautiful flower of most artistic form and striking general appearance. Solid lavender color. Tall plant, strong grower. Beautifully arranged in a funeral piece and shown at 
the A. G. S. show, Rochester, Aug., 1925 , this variety was awarded first prize for best funeral piece of lavender gladioli, A. G. S. Bronze Medal. Won two first prizes at the Mid-western Gladiolus Show, Des Moines, Sept., 1925, for best lavender. Again in 1926, this variety was awarded another A. G. S. Trophy. Each, 15c. Doz., \$1.50. Lavender Rose (1928. 84 days.)-Tall, stately and very graceful plant and fine foliage. Flowers large and very perfectly placed. Color is a most decidedly pure and beautiful delicate rose pink with beautiful blush of lavender. Central narrow bars of petals softest daffodil yellow. Lower petals have a beautiful delicate yellow blotch feathered rose pink at edges. A magnificent gladiolus and unsurpassed in beauty. Each, \$2.00. Doz., \$20.00.

Lemon Blushes (1931)-Large massive flower of beautiful form and of richest pure self cream color on upper petals. Large soft canary yellow throat on lower petals, with outer ends of same beautiful color as upper petals. Faintest blush of flesh tint on outer borders

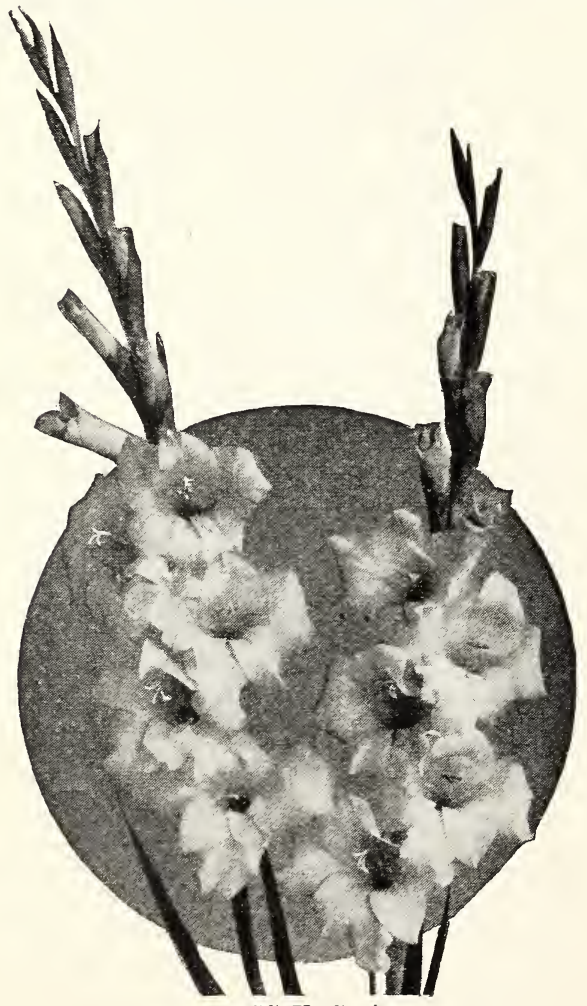

MISS U. S. A. Described on Page 51 of all six petals. A very distinct and wonderfully fine blending of softest pastel colors. Each, 75c. Doz., \$7.50.

Leopard (1930. 72 days.) - Graceful plant and a very neat and graceful flower. Ground color a fine tone of rose pink with short flakings or spots so uniformly distributed as to suggest its name. The spots are a beautiful deep rose red. The throat is a large, clear white, lightly flushed pink towards the base and outer portion of blotches is clear delicate soft creamy yellow delicately blended. An altogether distinct and very pretty flower. Each, 75c. Doz., \$7.50.

Lewis E. Gary (1931)-Tall stately and showy plant with six to eight and more perfectly placed large flowers open at a time. Unopened buds have a golden flesh tinted color but open flowers are of a very beautiful soft blush tinted cream with lower throat of purest canary yellow. When seen by the late Lewis E. Gary was considered by him the most beautiful among many thousands. Must be well grown to reach its great beauty. Each, $\$ 2.00$. Doz., \$20.00.

Lexington (1927. 86 days.)-Tall, stately and graceful plant. Foliage extra fine. Color a rich vermilion, lighter in upper throat with beautiful, soft, bluish tint on outer portion. Lower petals same color but deeper in throat. Fine, darkred, central lines. One of the finest cut spikes of all gladioli. A perfect spike, easily cut at great length without injury to foliage. A very beautiful red. Each, 15c. Doz., \$1.50. 100, $\$ 11.25$.

Little Red Star (1931)-Tall slender stem. Small gracefully placed upright flowers of fiery deep scarlet self color. A little darker in throat. Stigma and anthers are also upright, giving the flowers a very torch-like and pretty appearance. Each, 25c. Doz., \$2.50. $100, \$ 18.75$.

Loella (1918. 89 days.)-Smoky oldrose. Flaked deep smoky-blue. Very unusual and fine. Illustrated on inside back cover. Each, 10c. Doz., \$1.00. 100, $\$ 7.50$.

Louis F. Swift (1931)-Tall fine plant and six to eight large wide open flowers in bloom at a time. Color a striking shade of rose pink faintly tinted lavender and flaked deeper rose. Lower petals, in throat, of richest canary yellow taking on the rose pink blush of the flowers. Outer ends of same rose pink tone as upper petals. A distinct, striking and very beautiful flower in every way. Each, 75c. Doz., $\$ \mathbf{7 . 5 0}$. 
Examples of Kunderd's Ruffled Gladioli

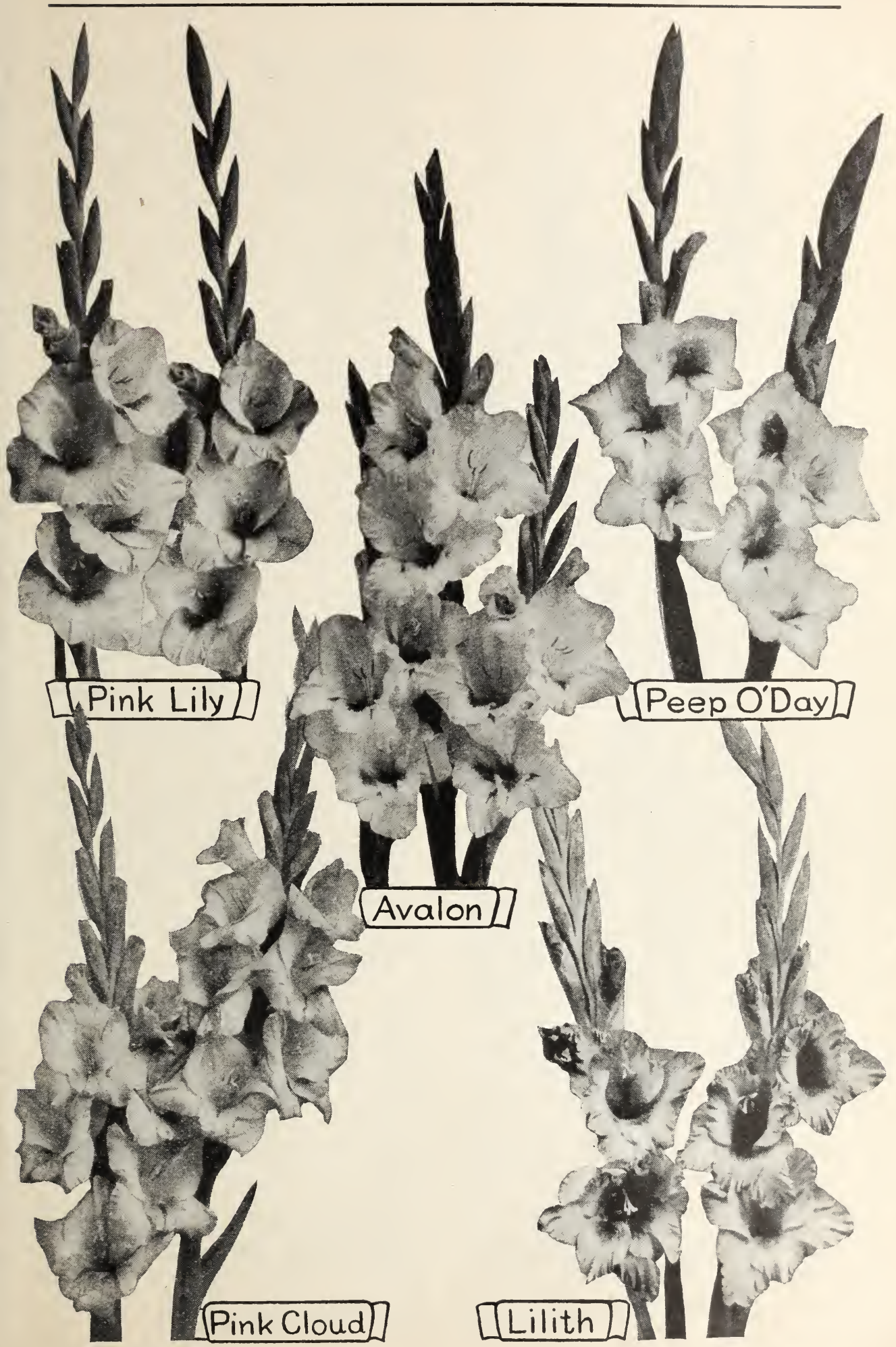




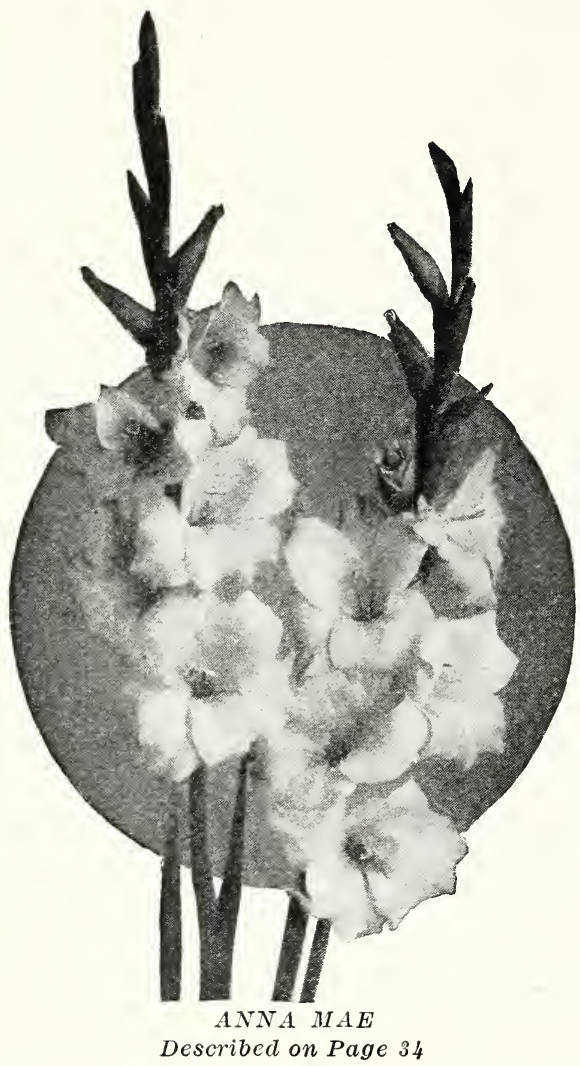

Lustre (1918. 87 days.) - Tall, large flowered orange-vermilion. Grand and beautiful. Illustrated on page 53 . Each, 10c. Doz., \$1.00. 100, \$7.50.

Luxury (1931)—Good height plant and large widely expanded flowers of very striking colors. Upper petals rich canary yellow prettily flushed soft red. Lower petals have most decidedly striking and brilliant red blotches like richest pansies covering most of the petals, with only the outer tips which are of a deep rich lemon yellow. Very beautiful and striking flower. Each, 75c. Doz., $\$ 7.50$.

Magic (1915. 67 days.) - Tall, finest lavender-blue. Large, rich, purple throat blotches. Fine. A very admirable basket made up of this variety and Purple Pansy received an A. G. S. Trophy for the best funeral basket at the 1926 A. G. S. show. Illustrated on inside front cover. Each, 8c. Doz., 80c. $100, \$ 6.00$.

Magnifica (1931) - Tall fine plant and large flowers with plenty open at a time. Color of richest salmon red, delicately flaked toward the outer end of all petals. Lower petals have large beautiful blotches delicately penciled white and orange. These again have a fine central bar of a dark velvety deep orange red. A very harmonious blending of beautiful colors. Very showy and fine. Each, 75c. Doz., \$7.50.

Magnificent (1928. 85 days.)-Extra tall and strong plant. Flowers large, massive and plenty open at a time. Ground color, a very mellow soft purple magnificently flaked deep purple red. Lower petals almost covered a deep, bright velvety red. A truly magnificent and showy flower. Each, 75c. Doz., $\$ 7.50$.

Mahogany (1930. 91 days.)-Tall stately plant with 5 or more large flowers open at a time. Ground color of self deep mahogany red. Large throat of beautiful clear, but dark red elegantly stippled on a white ground. Edges of throat blotches have a wide border of a glowing bright deep red. An elegant show and garden variety. Each, 50c. Doz., \$5.00.

Mahogany King (1928. 98 days.)-Tall, strong, stately plant. Flowers large, many open, perfectly placed. Color a very rich deep mahogany or brown red. Ends of petals a little brighter red. Very large, wide, elongated, pure white throat blotch with bright red, prettily feathered red border between the white throat and the ground color. A very extra and showy variety. Very desirable. Each, 35c. Doz., \$3.50. 100, $\$ 26.25$.

Mary Carmichael (1931) - Tall stately plant with six or more large, beautifully placed flowers open at a time. Color of most beautiful deep flesh pink over all petals, tinted faintest lavender rose pink. Inner portion of lower petals blended of most delicate soft creamy yellow. One of the most beautiful and dainty pastel or orchid shades. Impossible to describe. Very beautiful. Each, \$2.00. Doz., \$20.00.

Mary Fennell (1917. 81 days.)-Deeplilac, shading paler. Soft primroseyellow throat. Extra. Each, 8c. Doz., 80c. $100, \$ 6.00$.

Mary Jane (1925. 81 days.) - A plain petaled variety, which I have decided to name in honor of my beloved mother. A beautiful, silvery pink with light lavender sheen. Delicate, clear throat and many large, perfectly placed flowers open at a time. This variety won first prize for best new seedling at the A. G. S. shows, Kalamazoo, 1922. The Garden Club of America's silver medal. It was also 
awarded first prize at the Mid-western Gladiolus Show, Des Moines, Sept., 1925 , for the best variety selling that year for more than $\$ 10.00$ per bulb. Each, 50c. Doz., \$5.00.

Mary Pickford (1915. 70 days.) - An extraordinary flower and spike of most delicate creamy-white. Throat finest, soft sulphur-yellow. Stem and calix also white. Was awarded Certificate of Merit by Royal Horticultural Society, London, Aug. 10, 1920; also First Class Certificate of Merit by North Shore Horticultural Society, Manchester, Mass., summer of 1919, and winner of hundreds of other awards. Awarded first prize as best cream colored gladiolus without markings at A. G. S. show, Rochester, Aug., 1925. Illustrated on page 52. Each, 10c. Doz., $\$ 1.00$.

May Day (1928. 74 days.) - Fine, tall plant with a large, wide open flower and six or more open at a time. Color soft orange red with a white throat and dainty white lines minutely traced over all six petals. Unique but showy and fine. Each, 20c. Doz., \$2.00. 100, $\$ 15.00$.

Merton W. Wentworth (1919. 74 days.) -Very tall, and stately plant, blooms large and widely open outer petals delicate pink, shading to Marechal Niel yellow. Backs of petals show a tint of very delicate lavender. Lower petals wonderfully blotched American Beauty rose color. Illustrated on front cover. Each, 15c. Doz., \$1.50.

Me Too (1930. 83 days.) - Tall stately plant and spike with $6-8$ or more perfectly placed flowers open at a time. Color intense, dark maroon over entire flower, excepting large blackish maroon covering inner two-thirds of lower petals. The central one-third of the width of the blotches is of a much lighter red, elegantly blended with the blackish edges of the blotches. An extremely striking, rich and showy flower. Each, 75c. Doz., \$7.50.

Midway (1930. 87 days.) - Fine height plant and extra large flowers of purest deep salmon pink. Lower petals have a large soft yellow throat magnificently feathered and penciled deep salmon red. Throat is still further beautified by a narrow deeper red barred median line. An extra showy and beautiful flower in every way. Each, 50c. Doz., $\$ 5.00$.

Millionaire (1926. 65 days.)-Tall, elegant plant, many large flowers open at a time. Flowers richest velvety crimson, beautifully flaked geranium- red. Lower petals flaked deeper. Throat deeper red with creamy blotches, finely mottled and stippled. Very attractive variety. Each, 15c. Doz., \$1.50. 100, \$11.25.

Miss Bloomington (1929. 67 days.)-A very tall giant plant with six to eight or more very large, perfectly placed, rich lemon yellow blooms open at a time. A perfect self, only a little deeper yellow on lower petals. A wonderful grand, showy giant yellow. Illustrated on this page. Each, $\$ 1.00$. Doz., $\$ 10.00$.

Miss Universe (1929. 76 days.)-A neat plant of good height with six or more perfectly placed beautiful flowers open at a time. Bright red tyrian rose. Throat has large clear deep tyrian rose red blotch. A very striking flower greatly admired by all visitors at the field. Each, $\$ 2.00$. Doz., $\$ 20.00$.

Miss U. S. A. (1918. 77 days.)-Daintiest blush white. Very pure, refined and beautiful. Illustrated on page 48 . Each, 8c. Doz., 80c. 100, $\$ 6.00$.

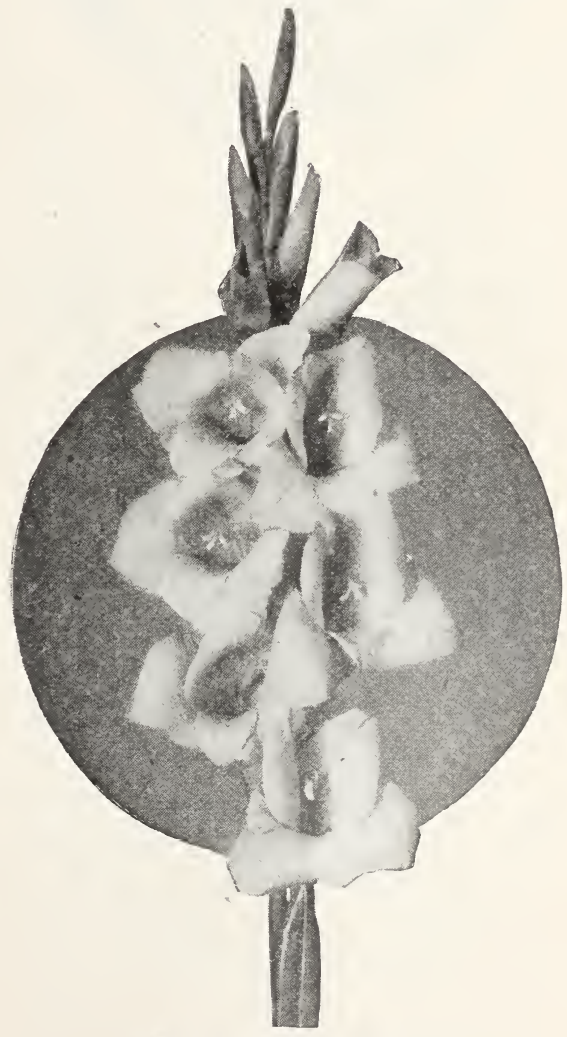

MIISS BLOOMINGTON Described on this page 


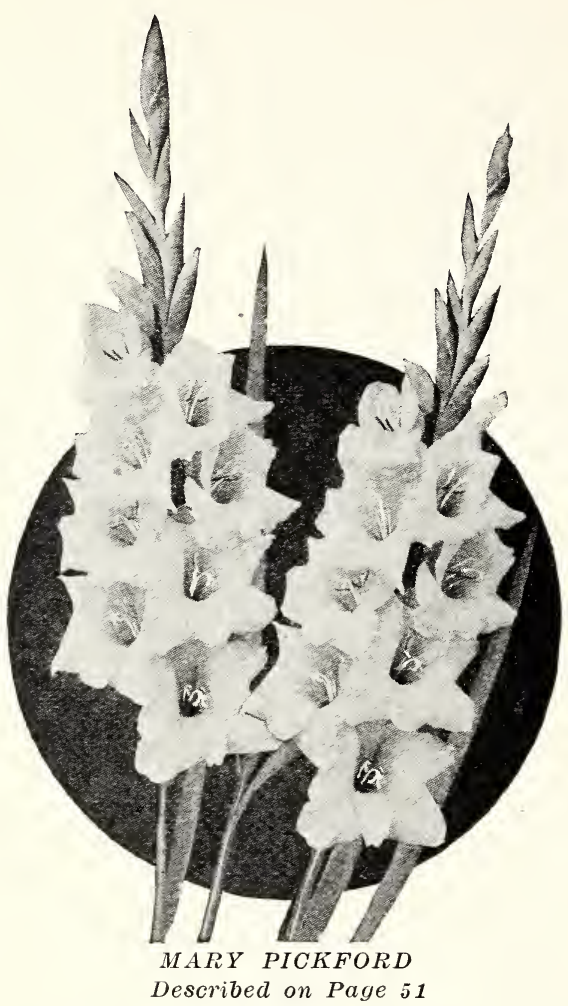

Modern Beauty (1930. 82 days.)-Tall fine plant and large flowers. Color white deeply blushed a soft lavender rose pink. Somewhat deeper on inner upper and the lower petals. Throat on lower petals has large clear creamy blotches edged deeper pink and with a narrow slight pencil line on midrib. An extra showy and fine florists' variety. Very choice. Each, 75c. Doz., $\$ 7.50$.

Modesty (1928. 88 days.)-Fine, strong plant with large flowers and six or more open at a time. Color a fine, light rose pink, and a large, deep rose red blotch in throat, with a dark red median line. Much like a "Pendleton" and very showy. Each, 15c. Doz., \$1.50. 100, $\$ 11.25$.

Mommie Dietz (1927. 74 days.)-Tall strong plant. Many large flowers open at a time. Color deep rose-pink of a very pleasing shade. Throat daintily marked deeper with fine, white pencilings. Entire flower finely flaked with finest shade of soft rose-red. This is one of the most unusual and beautiful of all gladioli. Each, 35c. Doz., \$3.50. $100, \$ 26.25$.
Monnie (1931) - Fine showy plant and flowers. Six to eight very dark flowers open at a time. Color intense deepest dark velvety maroon over entire flower. Throat still darker. Lightly ruffled. A very striking and showy "black" of perfect "self" color. Each, 75c. Doz., $\$ 7.50$.

Mottled Feather (1930. 80 days.)-Medium height plant of very neat appearance. Average of five fair sized flowers open at a time. Color, deep orange alternating with orange vermilion flaking. Central bars on petals usually all six white, with all white narrow thread line of white on the lower ones. Throat has a delicately subdued marking of faint rose-pink. An extremely rich colored fancy variety of great beauty. Each, 50c. Doz., \$5.00.

Mrs. Arthur Meeker (1917. 83 days.) Exceptionally fine, rich, deep American Beauty rose color. A very beautiful and unusual color. Each, 12c. Doz., $\$ 1.20$. 100, $\$ 9.00$.

Mrs. Chas. A. Stevens (1929. 72 days.) -Nice shapely plant of medium height with six to eight large blooms facing perfectly open at a time. Color a very fine shade of mellow purple all beautifully flaked a very rich deep rhodamine purple. Outside of petals deeper. Throat stippled a fine purple on a subdued white ground. One of the most beautiful gladioli imaginable. Each, $\$ 2.00$. Doz., $\$ 20.00$.

Mrs. Dr. Norton (1915. 78 days.)Finest cream and pink. The sensation at the American Gladiolus Society's shows. Everywhere awarded the highest honors. Illustrated on page 61 . Each, 8c. Doz., 80c. 100, \$6.00.

Mrs. E. A. Hamill (1931)-Tall strong vigorous yellow with six and more large flowers, perfectly placed, open at a time. Color a perfect yellow all over entire flower unmarred by any shade or marking. Far superior to Golden Measure, Gold, or any other yellow color and beautiful spikes and flowers. Perhaps as perfect a yellow as I have ever seen, and as pure as may ever be sent out. Each, $\$ 1.00$. Doz., $\$ 10.00$.

Mrs. Frank Pendleton (1910. 76 days.) Bright rose-pink on a pure white ground. A giant blotch of richest carmine-red on lower petals. No grander variety in existence. Awarded highest honors at the American Gladiolus Society, Mass. Horticultural Society, and many others. Each, 8c. Doz., 80c. $100, \$ 6.00$. 
Mrs. Geo. W. Hay (1931)-Very tall and stately plant with six to eight or more very beautiful flowers beautifully spaced and perfectly placed, open at a time. Color a pure self lavender rose, a little deeper in upper portion of throat, lower petals have a beautiful narrow feather or central bars of delicate soft rose red. One of the most elegant and best of all. A first class flower in every way for both the florist or in the garden. Each, \$5.00. Doz., \$50.00.

Mrs. Geo. W. Moulton (1915. 73 days.) -A giant, violet, red or cerise. Many open. Nicely placed on spike. An occasional blossom comes double. This variety was awarded first prize for the best rose colored gladiolus with markings at A. G. S. show, 1926. Illustrated on inside front cover. Each, 10c. Doz., $\$ 1.00$. 100, $\$ 7.50$.

Mrs. John T. Pirie (1931)-Tall stately plant with plenty of very large perfectly placed flowers open at a time. Color on upper side petals beautiful cream blushed daintily on outer portion. Central upper petal faintly blushed delicate lavender with faint lavender thread line on outer edge of petal blending inward on the petal. Lower petals richest soft canary yellow on inner portion taking on the color of the upper petals, towards the ends. The whole flower is magnificently beautiful beyond description and -truly wonderful. Each, $\$ 1.00$. Doz., $\$ 10.00$.

Mrs. Paul Dieball (1929. 85 days.) Extra tall fine plant with numerous very large and showy blooms open at a time. Color a decided glowing deep salmon pink. Lower throat somewhat deeper salmon. One of the most showy, distinct, and beautiful gladioli ever produced. Each, 35c. Doz., \$3.50. $100, \$ 26.25$.

Mrs. Walter Lytton (1929. 74 days.) Strong medium height plant with six to eight very massive blooms open at a time. Color a glowing pure deep salmon flesh over all the petals. Throat on lower petals of purest delicate creamy white faintly penciled toward the base. A very distinct and beautiful variety. Easily among the best. Each, 50c. Doz., \$5.00.

Northern Light (1930. 97 days.) $-\mathrm{Me}-$ dium height with five or more very large blooms open at a time. Lower petals and ends of upper a fine rose pink. Upper throat almost white, only faintly blushed. Lower throat a little darker than the darker portion of the petals. Back of flowers as beautiful as the face. Unusually colored and extremely fine. Each, 75c. Doz., \$7.50.
October (Quartinianus Hybrid) (1927. 85 days.)-Deep old rose red or wine color, of very large size. Flaked deeper. Throat charmingly marked red with fine white pencilings. A splendid garden and vase variety. Each, 20c. Doz., $\$ 2.00$. 100, $\$ 15.00$.

Odyssee (1930. 80 days.) - Good height and massive plant with seven and more large massive blooms open at a time. Flowers round in form with very wide round formed petals of strong substance. Color of finest white, very faintly blushed rose pink, slightly deeper towards the ends of all the petals. Fine throat blotches of pure soft rose red with deeper rose red central bars, the effect is much like a beautiful humming bird form with wide wings, and flying down the throat of the flower. Beautiful and showy flower. Each, 50c. Doz., \$5.00.

Opal Fringe (1930. 85 days.)-Medium tall plant with 6-8 and more flowers open at a time. Color, deep orange

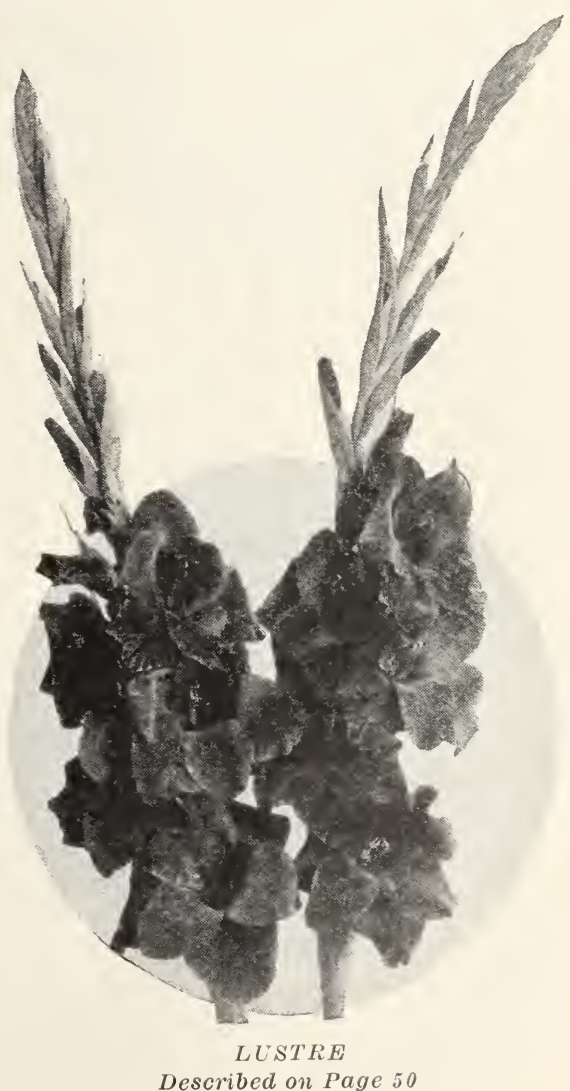

Described on Page 50 


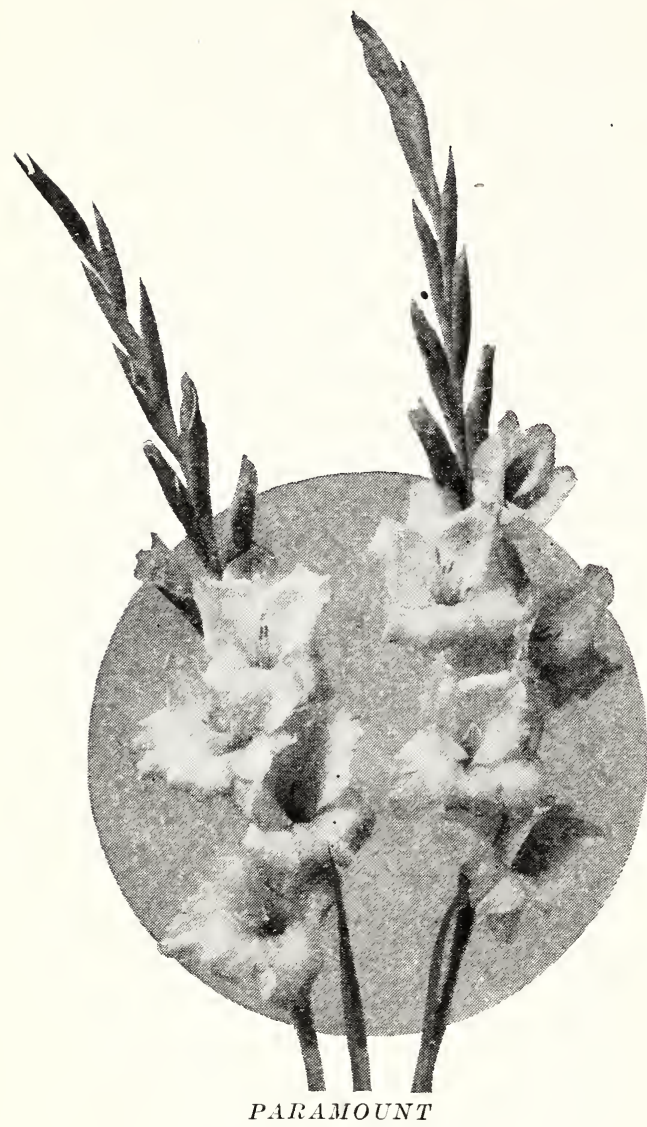

Described on This Page

salmon with very large dark velvety maroon red blotches on lower petals. Lightly and softly stippled a creamy white at edges of the blotches. A showy flower in the garden and for decorative effect. Each, 35c. Doz., \$3.50. $100, \$ 26.25$.

Opaline (1928. 105 days.)-Strong, vigorous plant, large massive flowers. Color soft, mellow violet purple. Fine, deep red throat. Very good for every purpose. Very showy and effective. Each, 15c. Doz., \$1.50. 100, \$11.25.

Oracle (1931) - Fine height plant and good size flower, color pure deep rose pink or rose red. Very large pure white throat with faint dainty pink thread lines or veins. A very clean, clear and beautiful white throated red. Each, 50c. Doz., \$5.00.

Orange Plume (1923. 70 days.) - Fine plant with beautiful drooping foliage. Large, pure, deep orange-red with softly blended, pure white central lines on all petals. Lower petals more white, with red central portions. Each, 12c. Doz., \$1.20. 100, $\$ 9.00$.

Orchidian (1928. 66 days.) - Tall, stately plant with many large, perfectly placed flowers open at a time. Upper petals deep violet pink. Entire lower petals covered a beautiful, velvety, deep claret red, with edges beautifully bordered same color as the upper petals. Very striking with noticeable orchid colorings. Each, 35c. Doz., $\$ 3.50$. $100, \$ 26.25$.

Pal O'Mine (1930. 75 days.)-Good height plant and large flowers, six and more open at a time facing perfectly. Color, deep purple rose, flaked dark purple on upper petals, deeper at edges. Throat, upper portion much lighter. Lower petals entirely covered deep velvety red purple, deeper towards the center, but lightening towards the base of the throat. A clear narrow line of golden yellow extends clear around all of the lower petals giving the flowers a very unique and beautiful effect. Each, 50c. Doz., \$5.00.

Pantheon (1922. 73 days.) - A large and massive waxy white on tall, strong plant. Lower petals beautifully penciled and feathered rose. Illustrated on page 28. Each, 8c. Doz., 80c. 100, $\$ 6.00$.

Paramount (1918. 82 days.) - A wonderful blending of pink and cream. Similar to Mrs. Dr. Norton. Awarded first prize at Mid-western Gladiolus Show, Des Moines, Sept., 1925, for best light pink. Illustrated on this page. Each, 20c. Doz., \$2.00. 100, $\$ 15.00$.

Pauline Kunderd (1926. 87 days.)-The new wonder Gladiolus. A pure rosepink of most fresh and delightful tone, with throat of finest cream in perfectly harmonious blending with the pink. I do not believe there is a finer gladiolus in existence today. Destined to become famous. Each, 50c. Doz., $\$ 5.00$.

Peach Blushes (1931)-Neat, fine plant with four or more good size flowers open at a time. Color on all petals a beautiful peach blossom pink. Upper throat a little lighter. Lower petals have fine rose pink blotches of pretty form and prettily blended with the main color, which is of the much-admired peach blossom pink. All petals have a blushed lighter border, giving the entire flower a very beautiful effect. A distinct and attractive flower, lightly ruffled. Each, 50c. Doz., \$5.00.

Peach Bud (1930. 77 days.) - Tall, graceful plant with six to eight nice size

\section{Glorify Your Garden with Kunderd Gladioli}


and very perfectly spaced flowers, uniformly placed, open at a time. Color a clear and wonderful shade of deep rose-pink. Throat lighter in upper portion and has a magnificent blotch of richest rose red on lower petals. One of the richest and purest colors yet produced. Each, 50c. Doz., \$5.00.

Peach Glow (1930. 110 days.)-Medium height and graceful plant. Flowers large and very graceful form. Color deep peach blossom, flaked deep rose pink. Throat a little deeper, rose pink. Opening buds very elegant. Of ruffled form, somewhat upright, and as in the ruffled Gladioli a far more beautiful opening bud than are the buds of the plain petaled varieties. A very fine variety. Each, 50c. Doz., \$5.00.

Peacock (1930. 82 days.)-Medium tall and fine plant, with good sized flowers. Color a light rose pink with striking and large showy blotches which show clearly in five color tones beside the basic or ground color of rose pink. Upper petals show the "eyes" clear across the petals near the outer ends. Another "Gloxinia" like variety, rich and showy. Each, 50c. Doz., \$5.00.

Persepolis (1929. 81 days.)-Fine height and shapely plant. Six or more very perfectly placed blooms open at a time. Color a clean white ground over all the petals with a pure soft very delicate rose pink blush very evenly spread over the entire flower. Over all is again a very delicate shade of soft lavender. Throat has moderate blotches of deep purplish red beautifully feathered and penciled with same shade as ground color. Each, 35c. Doz., $\$ 3.50$. 100, $\$ 26.25$.

Philatelia (1927. 83 days.) - Large, strong, vigorous plant. Flowers very large. Color deep tyrian-rose. Upper portion of throat lighter. Lower petals feathered darker than main color. One of the best gladioli produced in recent years. As a landscape and vase variety it would be very hard to surpass. Each, 50c. Doz., \$5.00.

Philip Breitmeyer (1929. 73 days.)Tall fine plant with many large and beautifully placed flowers open at a time. Color a very rich rose pink with a delicate lavender tone over entire flower. Throat has wide dark red median lines with paralleled thread lines of same color on a whitish ground. A very choice and showy variety. Each, 50c. Doz., \$5.00.

Pink Beam (1928. 72 days.) - A tall, vigorous plant with plenty very large wide open flowers open at a time.
Ground color beautiful blushed or flaked white. Upper and lower petals striped with a refined rose-pink. Central bars on lower petals have a long, narrow bar of deep, rich maroon penciled with narrower pencil lines of same color. Each, 20c. Doz., $\$ 2.00$. 100, $\$ 15.00$.

Pink Clover (1930. 94 days.)-Tall fine plant and with six or more large flowers open at a time. Color, rose pink, tinted slightly lavender and deeper on lower petals. Upper, inner throat blended from the edges to an almost white, giving the flowers a very unusual and striking appearance. Very showy. A distinct and beautiful variety. Each, 35c. Doz., \$3.50. 100, $\$ 26.25$.

Pink Delight (1928. 71 days.)-A strong, tall plant with many large and showy blooms, perfectly placed, open at a time. Flowers of good size, tubular in form, and of loveliest shade of soft, rich rose pink. Throat a delicate

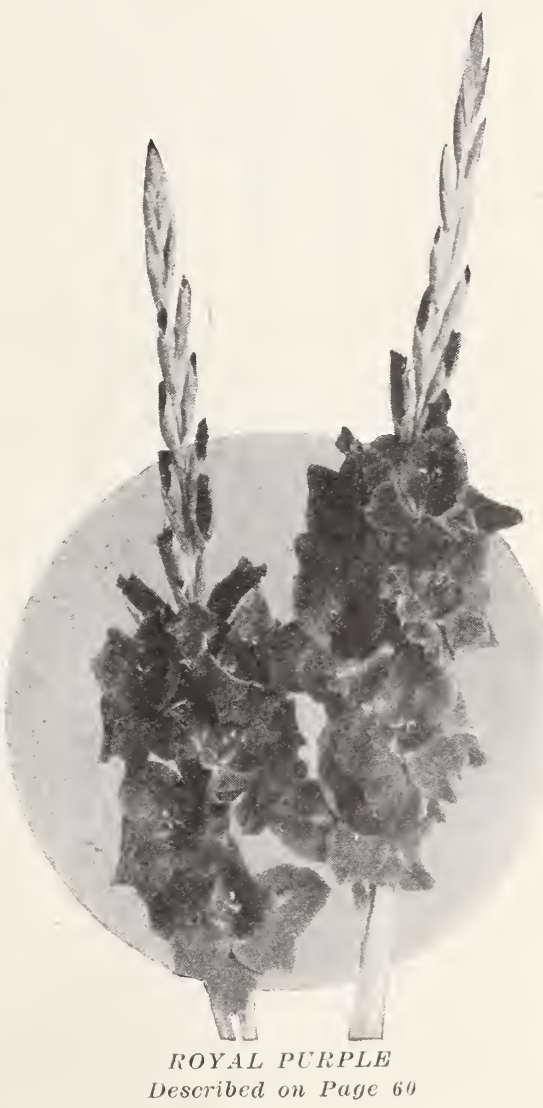




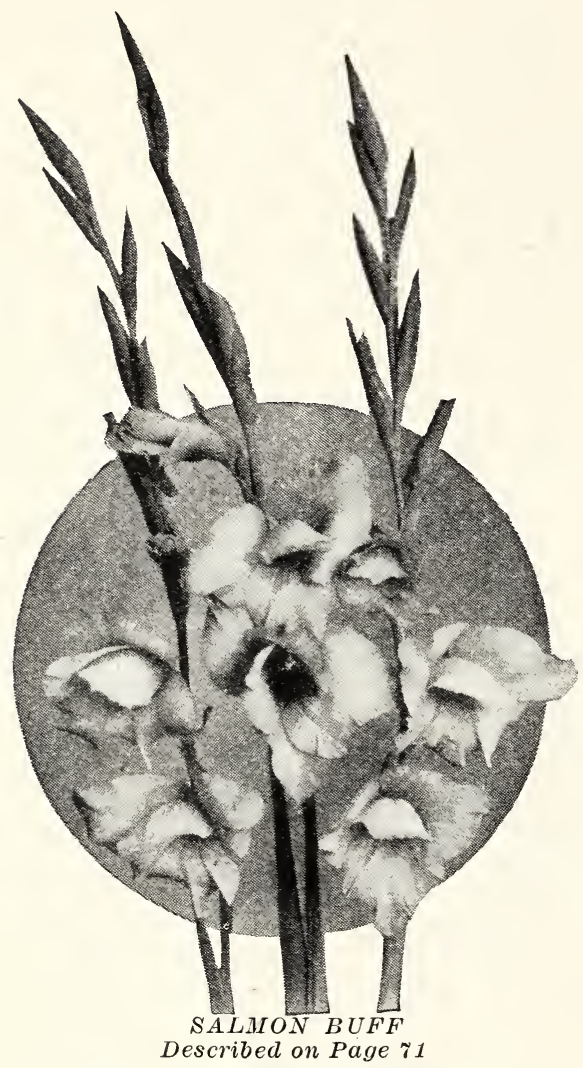

whitish cream and deeper soft yellow across middle of lower petals. Each, 50c. Doz., $\$ 5.00$.

Pink Enchantor (1929. 80 days.) - Tall fine plant with five or more large flowers open at a time. Petals all widely expanded with upper one very upright giving the flowers a diamond shape. Color of the richest glowing rose pink imaginable. Lower throat portion deeper or rose red. A very beautiful variety. Each, 75c. Doz., $\$ 7.50$.

Pink Favorite (1930. 102 days.) - Medium tall plant with six or more large showy blooms open at a time, all perfectly placed and color uniformly rose pink all over, excepting a fine deep rose red median line in throat. Appearance of fine self color rose pink. A splendid variety. Each, 35c. Doz., $\$ 3.50$. 100, \$26.25.

Planada (1929. 77 days.)-Tall, strong plant with a very large showy flower of fine delicate rose pink color. Rich showy dark central bars paralleled in fine tracery of same color. A showy throat and a very fine pink variety. Each, 25c. Doz., \$2.50. 100, \$18.75.
Pompeian Beauty (1927. 73 days.) - A very large flower, round in shape and wide open. Extra strong plant. Color a pleasing, deep rose-pink. Fine, large throat markings of red with neat white. points extending through central lines on lower petals. Five and six perfect blooms open at a time. Lightly ruffled. Excellent bouquet and garden variety. Each, 20c. Doz., \$2.00. 100, \$15.00.

Pond Lily (1929. 80 days.)-Fine height showy plant. Numerous quite large most beautiful deep rose-pink flowers. Deeper in throat with still deeper central bars on lower petals. A very beautiful pure rich deep bright rose pink variety. Grand and beautiful. Each, 75c. Doz., $\$ 7.50$.

Predominator (1929. 86 days.) - Extremely tall, slender and graceful plant with five or more large widely opened flowers in bloom at a time. Color of richest salmon scarlet. Lower petals of same color but with a fine wide feather of a beautiful velvety deep red, with narrow creamy-white line extending from the red about onehalf inch. By far the tallest in a field of over 30,000 varieties. A very desirable garden and cut flower variety. Each, 35c. Doz., \$3.50. 100, \$26.25.

Pretty Pink (1929. 85 days.) - Fine plant with large (five and more), very beautiful rose-pink colored blooms open at a time. Throat a little deeper on lower petals. Extra choice and fine. Scarce. Each, 75c. Doz., \$7.50.

Prof. C. S. Sargent (1927. 85 days.)Giant plant of striking appearance. Flowers large. Color clean white, slightly pink with very light crimson marking on lower petals. Of such unusual beauty that it is easy to predict great popularity for this kind. Named in honor of the great curator of Arnold Arboretum, Boston. Each, 75c. Doz., \$7.50.

Prof. E. H. Wilson (Quartinianus Hybrid.) (1929. 113 days.)-Giant plant. Large, massive flowers. Color a rich, pure orange-red. On lower petals a narrow central bar of deep dark-red. Many blooms open at a time. Very late variety. An immense show flower. Named in honor of the late horticultural explorer and the man who gave America the wonderful Regal Lily. Each, 75c. Doz., \$7.50.

Purple Beauty (1930. 97 days.) - Medium height plant and good size flowers of a deep purple violet. Throat has blotches as large as "Pendleton" clear to base of flowers, bordered at outer portion a subdued white. A con- 
spicuous and richly colored variety. Each, 25c. Doz., \$2.50. 100, \$18.75.

Purple Challenge (1928. 83 days.) Tall, stately plant, perfectly formed with fine foliage. Flowers very large and of a very distinct, pure and showy, deep red purple. Far surpasses much similar varieties as Anna Eberius, Elkhart, Jacoba Van Beyren and similar kinds. A good plant and flower in every way. A rapid multiplier. No doubt among the very greatest. Each, 75c. Doz., \$7.50.

Purple Crown (1930. 94 days.) - Tall, stately plant. Six or more good sized flowers open at a time. Color dark velvety purple, darker on lower petals and darkening towards the base of throat. A short narrow bar of subdued white extends from the dark purple blotches on the lower petals lightening up the whole flower very effectively. A distinct and showy flower of very rich coloring. Each, 50c. Doz., $\$ 5.00$.

Purple Pansy (1915. 73 days.) - Tall, slender plant. Plenty of blooms open at a time. Richest deep - purple, fine pansy-like throat. A very favorable impression was made with my stunning basket of this variety used with Magic. This was one of the most artistic baskets at the A. G. S. show, 1926, and was awarded an A. G. S. Trophy for the best funeral basket. Each, 12c. Doz., \$1.20. 100, $\$ 9.00$.

Purple Progress (1929. 72 days.)-Tall fine plant. Flowers much larger and showier than "Baron J. Hulot" and much finer in every way but almost of exactly the same color. Received a medal of The American Gladiolus Society for best new seedling. A grand "Baron J. Hulot" improved. Each, $\$ 3.00$. Doz., $\$ 30.00$.

Purple Spot (1918. 84 days.) - Large violet-red with very conspicuous dark blotches. Early, showy. Each, 10c. Doz., $\$ 1.00$.

Quartin Dillon (1928. 104 days.) - Tall, strong plant with many large flowers open at a time and all facing perfectly one way. Color very dark mahogany brown red. Large throat blotches of a deep bluish red, edged rose red. Very rich and showy garden and show flower. Each, 15c. Doz., \$1.50. 100, \$11.25.

Queen of Orange (1929. 67 days.) Tall stately slender plant. Large round flowers of a brilliant orange red. Lower petals have five to seven narrow thread lines alternating red and yellow on a deeper orange red. Back of flowers nearly a pure self, but face of flower is finely traced all over with very fine pencilings of yel low. One of the most distinct and outstanding varieties. An extra showy landscape variety. Most showy at a little distance. Each, 25c. Doz., \$2.50. $100, \$ 18.75$.

Rajah (1917. 78 days.)-A well-known very choice giant dark red. Awarded first prize for best red without markings, at the A. G. S. show, Rochester, Aug., 1925. Again in 1926, this variety received first prize as the best dark-red variety, A. G. S. show. Illustrated on inside back cover. Each, 20c. Doz., $\$ 2.00$.

Red Beauty (1930. 96 days.) - Neat height plant with five or more fine and shapely medium sized flowers open at a time. Color a very rich bright deep velvety red, flaked much deeper at the edges of the petals. Lower inside petals very rich darker red and have slight median line of white extending over outer half of throat, about half towards the end of the petals. A very rich and beautiful deep red variety. Each, 25c. Doz., \$2.50. 100, \$18.75.

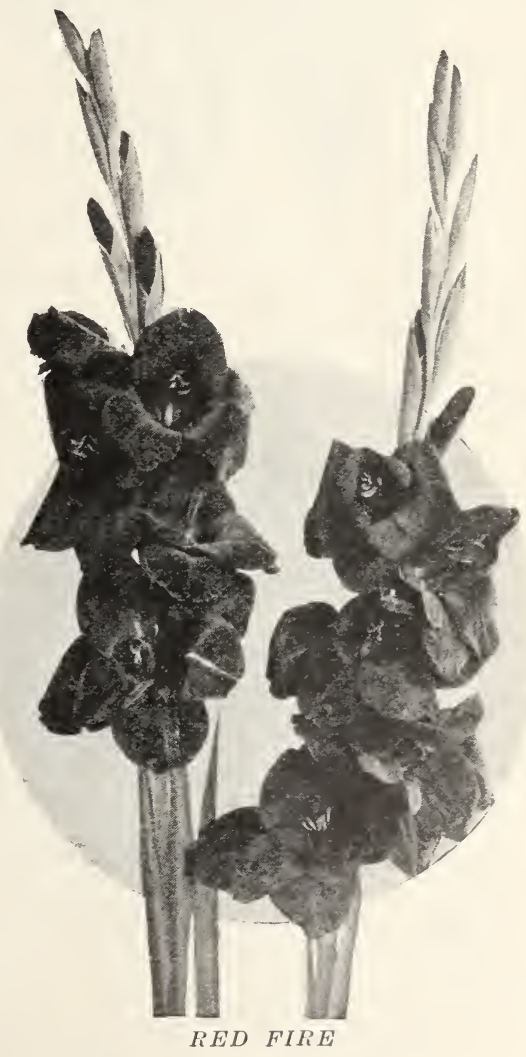

Described on Page 58 


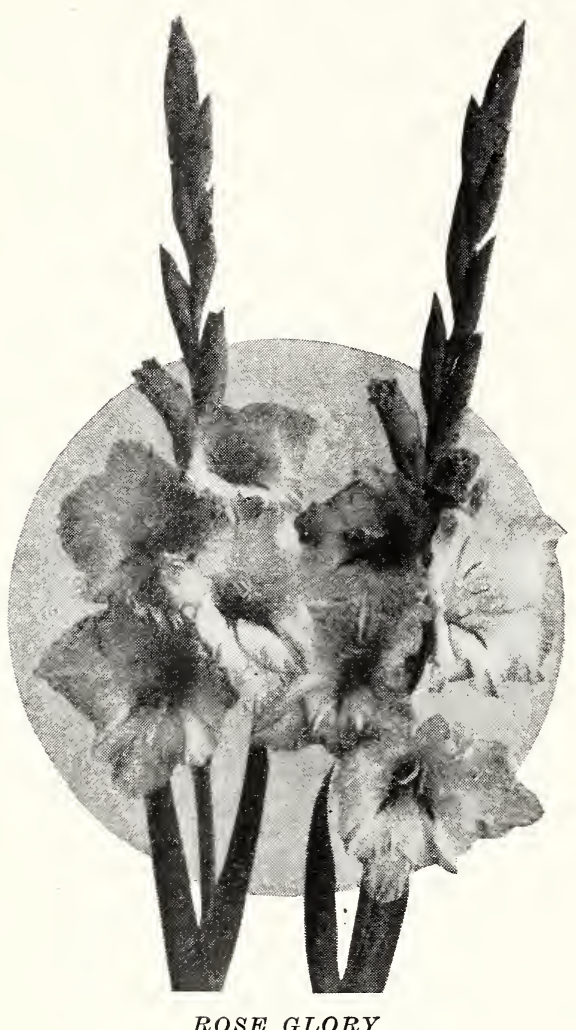

Described on Page 30

Red Butterfly (1928. 92 days.) - Fine plant and flower. Bright rose red with beautiful, deep red throat blotches. These again have deeper, rich, velvety red median lines or mid-rib. A beautiful and showy variety. Each, 20c. Doz., $\$ 2.00$. $100, \$ 15.00$.

Red Cardinal (1928. 72 days.) - Tall, stately plant with a long spike of blooms, beautifully and gracefully placed. Exceedingly showy blooms of indescribably beautiful, deep cardinal scarlet. Has a large, pure white throat with fine, deeper red central bars. Beautiful and distinct. Each, 50c. Doz., \$5.00.

Red Charm (1928. 80 days.)-Tall, fine and perfect plant with five and more large, showy, deep blood red flowers open at a time. The outer one-half of lower petals same rich red with deep, velvety, dark or blackish red throat blotches. A first class red. Each, 35c. Doz., \$3.50. 100, \$26.25.

Red Cherry (1928. 83 days.) - Extra tall, graceful and slender plant. Flowers good sized and widely expanded.
Color bright, rich red and deeper on lower petals. An extraordinarily fine plant and a rich, showy flower. Each, 12c. Doz., $\$ 1.20$. 100, $\$ 9.00$.

Red Cloud (1921. 84 days.) - Grand. Bright-red. Many flowers open. White bar in three lower petals. One of the most talked-of varieties at the Midwestern Gladiolus Show, Des Moines, Sept., 1925. Each, 10c. Doz., \$1.00. 100, $\$ 7.50$.

Red Commander (1928. 99 days.)--Tall and very vigorous plant. Very large and massive flowers of deep, rich red. Faintly flaked deeper red on outer portion of all the petals and deeper led in throat. A giant and showy late red, an extra fine Quartinianus Hybrid. Each, 20c. Doz., \$2.00. 100, \$15.00.

Red Copper (1921. 80 days.) - Large flowers, deep salmon - rose, heavily flaked blue. Lower petals red, white and yellow, lined and penciled with blue. A choice, fancy color. Each, 8c. Doz., 80c. $100, \$ 6.00$.

Red Darling (1929. 89 days.) - Neat medium sized plant and flower. Color a very pleasing, velvety dark cardinal red. Upper portion a little lighter in throat. Lower petals have large dark velvety blotches with still darker red median lines extending beyond the blotches. A very neat and attractive red with colors very prettily blended. A little beauty. Each, 20c. Doz., \$2.00. $100, \$ 15.00$.

Red Empire (1928. 95 days.) - Fine plant and very large flowers on a Princeps seedling, but with more flowers open at a time. Color a deep, cherry red, deeper in throat. A giant showy flower. An outstanding red. Each, 20c. Doz., \$2.00. 100, $\$ 15.00$.

Red Fire (1922. 80 days.)-A seedling of Princeps. Entire flower of richest, pure self-colored bright-red. Very striking and showy. Our best brightred gladiolus. Illustrated on page 57 . Each, 15c. Doz., \$1.50.

Red Mahogany (1931) - Tall, slender, graceful plant. Flowers medium size and five to seven open at a time. Color intense mahogany deepest brown red over all the petals excepting the throat is of deep blackish red self color. A very richly colored and showy garden flower. Each, 35c. Doz., \$3.50. 100, $\$ 26.25$.

Red Roamer (1928. 83 days.)-Giant red variety of the Nanceianus form. Many flowers open at a time. Frequently laciniated. Very fine. Each, 35c. Doz., $\$ 3.50$. $100, \$ 26.25$. 
Red Rock (1930. 83 days.) - Of good height and a strong, vigorous plant. Flowers very large and massive. Color deep blood red, deeper over entire lower petals. Lower petals also have fine narrow very dark velvety red central bar. The whole effect is a rich "self" colored deep red of magnificent and showy appearance. Each, 50c. Doz., $\$ 5.00$.

Red Rose (1930. 86 days.)-Fine plant and large flower. A pure red rose, a little deeper rose red on lower petals. Slightly darker median line extends down the lower portion of the throat, enhancing the beauty of this flower still farther. Each 75c. Doz., \$7.50.

Red Velvet (1927. 89 days.)-Deep-cardinal or blood-red. Delicately flaked deeper red. Throat bars are of darker red and pure white in narrow lines alternating beautifully. The most velvety as well as the most beautiful deep-red I have ever seen. A shade of red as beautiful as the famous cardinal flower or scarlet lobelia. Wonderfully beautiful. Each, 35c. Doz., $\$ 3.50$. 100, \$26.25.

Remarkable (1927. 69 days.)-Very large, round blooms on strong spike. Vigorous plant. Color of a pleasing cherry-rose with entire lower petals deep rose-red, giving this variety a striking appearance. A marvel of beauty and one of the most outstanding garden varieties. Each, 50c. Doz., $\$ 5.00$.

Rhapsody (1929. 73 days.)-Tall neat plant. Numerous bright rose-pink flowers of pure self color effect with only a slightly deeper throat. Bright, showy and attractive. Each, 35c. Doz., \$3.50. 100, \$26.25.

Robert J. Kunderd (1918. 80 days.)Medium tall, very large, most brilliant, deep-vermilion or orange-scarlet. A wonderful showy self-color. Each, 12c. Doz., $\$ 1.20$. 100, $\$ 9.00$.

Robinette (1929. 70 days.)-Plant medium height with large flowers, five or more open at a time, correctly placed and all facing one way. Color tyrian rose considerably lighter towards the throat and upper portion. Beautiful slight penciling's and veinings on lower petals. In all a very pleasing and attractive variety. Each, 50c. Doz., \$5.00.

Rolling Prairie (1930. 105 days.)-Tall fine plant with beautiful deep rose pink flowers, flaked slightly a little deeper. Lower throat has a large showy, beautifully blended deeper rose throat with slight faint narrow median line on midrib. Back of lower petal has a creamy white ribbon showing on the outside of the petals, giving a very pleasing and unique effect. A refined and rich flower. Each, 50c. Doz., \$5.00.

Roman Candle (1929. 83 days.)-Tall fine beautiful plant. Color most beautiful pure soft self salmon red. Throat deeper. Very showy and grand. A color hard to describe but of the most beautiful shade imaginable. Each, 50c. Doz., $\$ 5.00$.

Romance (1918. 71 days.) - Large, orange, salmon, rose, red and yellow throat. Wine-blue bordered petals. Unusually distinct and very showy. Winner of two first prizes. A. G. S. show, 1926. Illustrated on page 39. Each, 10c. Doz., \$1.00. 100, $\$ 7.50$.

Rose (1923. 77 days.)-Extra strong, large plant. Large, showy flowers of a pure, deep rose-pink color with large, beautiful deep-red throat blotches. Very fine. Each, 15c. Doz., \$1.50. 100, $\$ 11.25$.

Rosea (1928. 67 days.)-Good height and fine shaped plant. Flowers large and of fine form with five or more blooms open at a time. Color a deep salmon rose prettily flaked a pleasing shade of deeper rose. Throat stippled still deeper rose red on a white ground

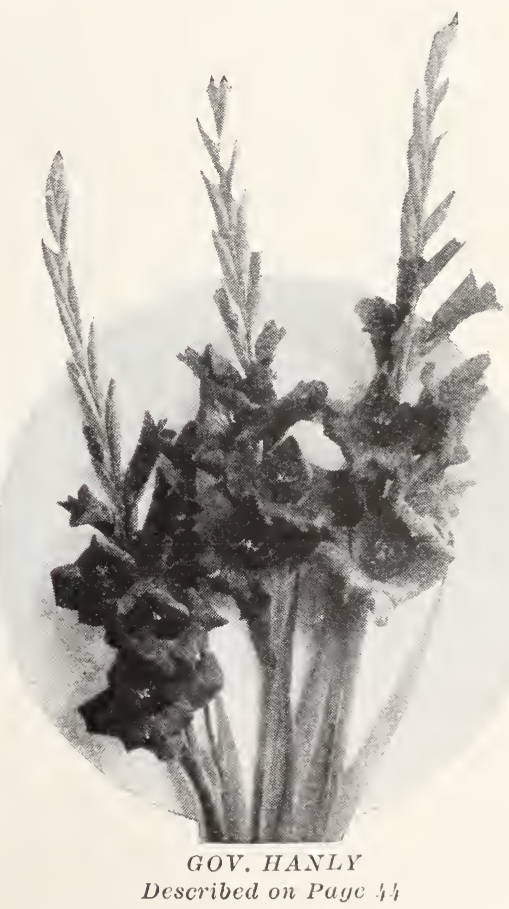




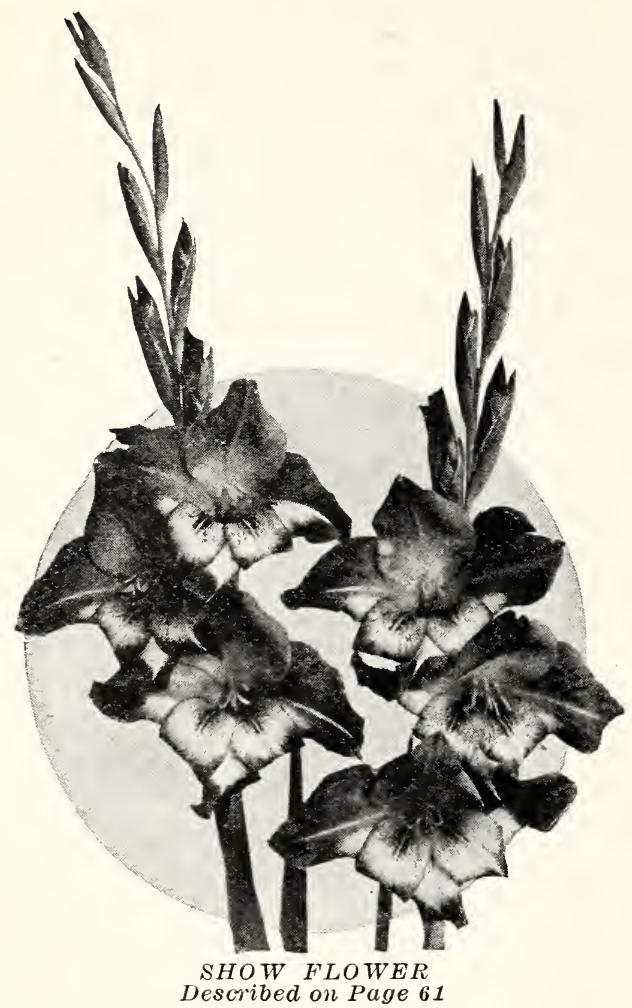

and outer portion of blotches terminating a fine white. The whole flower and spike of graceful appearance and regular in form. Each, 25c. Doz., $\$ 2.50$. 100, $\$ 18.75$.

Rose Ann (1930. 108 days.)-Tall strong plant and grand flower. Color rose salmon with finely feathered lower center and a beautiful deep red central bar. A gorgeous and showy variety. Truly magnificent and must be seen to be appreciated. Each, 75c. Doz., $\$ 7.50$.

Rose Feather (1930. 84 days.)-Fine, height plant and good sized blooms of soft rose pink, tinted old rose, and elegantly flaked deeper rose. Throat a deeper pink, or light rose red with deeper red median line, or central bar on lower petals. A pretty plant and flower. Each, 35c. Doz., \$3.50. 100, $\$ 26.25$.

Rose Pearl (1928. 78 days.)-Tall, fine plant, large, wide open flowers beautifully placed. Color finest pure, deep rose pink imaginable. Throat a fine, deep rose stippled white in daintiest manner. Deeper narrow median lines. Color as fine as E. J. Shaylor. Each, 15c. Doz., \$1.50. 100, \$11.25.
Rose Pendleton (1930. 89 days.)-Medium tall, fine plant. Flowers not quite so large as "Pendleton," but reminds one much of that great variety. Color deep rose pink with much darker rose red blotch than in the "Pendleton" and of glowing velvety dark red. A uniform even self colored variety, except the very striking blotches. Each, 35c. Doz., \$3.50. 100, \$26.25.

Rose Splendor (1930. 91 days.)-Fine size plant and large flowers, six and more open at a time. Color a fine self rose pink over all six petals, each having a clear sixteenth inch white border around all of the petals. Pronounced dark rose-red throat. The back of the flower is of the same beautiful rose pink with the narrow white border of the petals charmingly enhancing the beauty of this flower. Distinct. Each, 50c. Doz., \$5.00.

Rosy Glow (1918. 83 days.)-Giant plant, massive flower of fine rose-pink on white ground. Very beautiful. Each, 10c. Doz., \$1.00. 100, \$7.50.

Rosy Smoke (1928. 84 days.)-Tall, extra vigorous plant with large, massive blooms and plenty open. Color deep salmon red flaked a deep smoky old rose. Base of throat beautifully striped red and white. Large wine blue throat blotches with very red central bars terminating white subdued under soft red. An extra showy variety in the richly or fancy colored class. Each, 25c. Doz., \$2.50. 100, \$18.75.

Royal (1928. 86 days.)-Tall, fine plant with large, wide open, roundish flowers. Color dark, velvety red. Deeper throat edged brighter red. Petals flaked a deeper red. A choice, rich, showy red. Each, 25c. Doz., \$2.50. 100, \$18.75.

Royal Beauty (1930. 74 days.)-Tall, stately plant with five or more large perfect flowers open at a time. Color a very rich deep purple red. Large and very beautiful deep velvety dark purple red throat which greatly enhances the beauty of this flower. Each, 50c. Doz., \$5.00.

Royal Purple (Quartinianus Hybrid) (1927. 101 days.) A very large bloom of richest volet-purple, slightly red cast. The most beautiful variety known to me in this color. Strong plant, spike tall and slender, making it extra fine for cutting. In great favor at the A. G. S. shows in 1925 and 1926. Illustrated on page 55. Each, 35c. Doz., $\$ 3.50$. 100, \$26.25.

Rozan Marie (1931)-Tall stately plant with plenty of large showy flowers open at a time. Color a delightful pure 
rich deep coral pink, or light coral red over entire flower, deepening at outer edges of all the petals which are as beautifully recurved as a lily. Lower petals have deep coral red feathered blotch in finest harmony with entire flower. A distinct and beautiful flower of great beauty, form and general appearance. Each, 75c. Doz., \$7.50.

Salmon Fins (1930. 66 days.)-Strong medium size plant with a giant full rounded beautiful flower of most glowing deep bright salmon rose flowers. Lighter in upper portion of throat and a deep orange red over all of the lower petals. Center of lower petals have deep red central bars enhancing still further an already exceptional striking and showy variety. Each, 75c. Doz., $\$ 7.50$.

Salmon Star (1928. 73 days.)-Tall, fine, shapely plant. Six or more good sized blooms open at a time. Color a decided soft self, deep salmon pink, of a mellow tint equal to the best pastel shade in this color. Throat a pure, soft canary yellow blending perfectly with the main color. An extremely beautiful variety. Each, 50c. Doz., \$5.00.

Sammy Lane (1930. 84 days.)-Flowers large and five or more open at a time. Color a light flesh pink. Lower petals on inner portion are a beautiful white with four narrow rose colored pencil lines alternating with three white narrow pencil lines extending half the length of the petals. Opening buds show a deep and very beautiful shade of deep shrimp pink giving open flowers a greater charm and beauty. Each, 35c. Doz., $\$ 3.50$. 100, $\$ 26.25$.

San Francisco (Quartinianus Hybrid) (1927. 89 days.) - Large flower. Darkmaroon on wine color. Lower petals daintily penciled a light creamy-white. Self-color effect. Strong plant. Each, 20c. Doz., \$2.00. 100, \$15.00.

Scarlet King. 1929. 88 days.)-Good strong plant with a giant flower of a very intense scarlet. Unsurpassed by any other red. A wonderful red. Scarce. Each, \$1.00. Doz., \$10.00.

Scarlet Princeps* (1917. 74 days.)-Six or more massive bright red blooms open at a time. Throat a little deeper. Blooms set close. An extraordinary, distinct and massive spike. Won a first prize at A. G. S. show, Rochester, Aug., 1925. Winner of many other awards. Illustrated on page 35. Each, 8c. Doz., 80 c. $100, \$ 6.00$.

Scarlet Princeps has been unjustly renamed "Virginia" by some California parties.
Senator Beveridge (1930. 103 days.) Tall, extra fine plant with medium large and very perfect flowers. Color, pure light blood red, feathered very delicately a little deeper red on throat of lower petals. From these throat feathers an almost imperceptible narrow thread line extends about onefourth of the petal's length. A more beautiful and elegant red is hard to imagine, and the flowers are extremely rich and showy in artificial light as well as in the garden. As fine as the finest. Each, 75c. Doz., $\$ 7.50$.

Show Flower (1923. 70 days.)-A giant flower of great attractiveness. All petals of fine shade of rose-red with immense white face, mottled deeper in throat. Violet and white upper throat. Very extra. Illustrated on page 60. Each, 12c. Doz., \$1.20. 100, $\$ 9.00$.

Silver Cloud (1930. 72 days.) - Very tall and stately plant with six or more very large flowers open at a time. Buds of a clear pure soft canary yel-

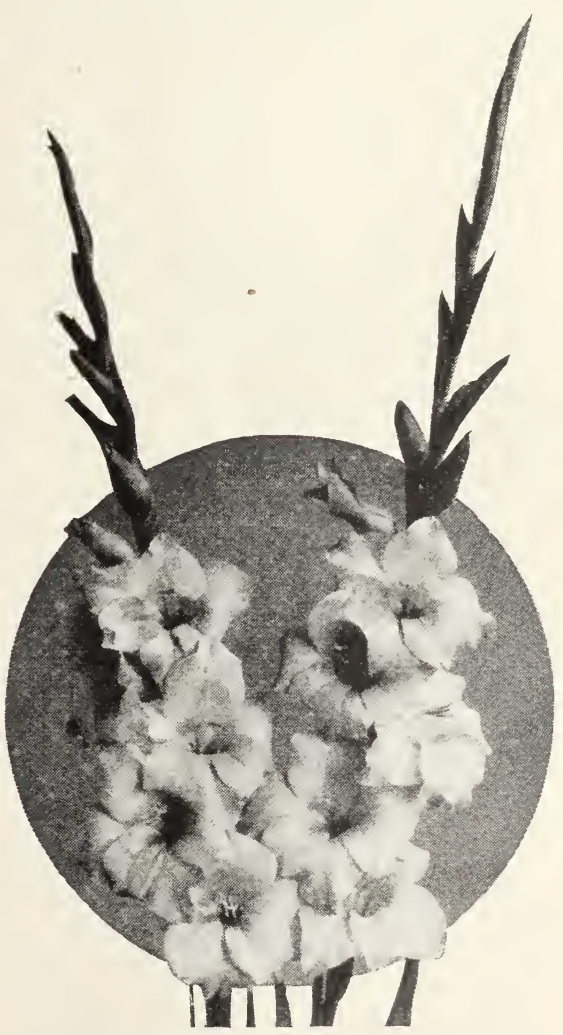

MRS. DR. NORTON

Described on Page 52 


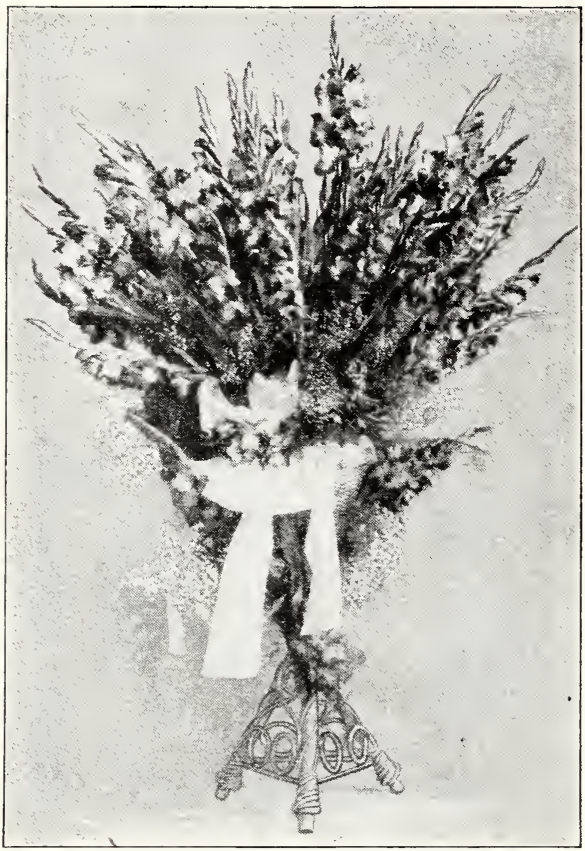

An exhibition basket containing the beautiful variety Dr. Nelson Shook. This arrangement shows the vast possibilities of Gladioli for basket work. The use of one variety is highly recommended. See illustration on page 43.

low. Flowers soft cream-white with single thread line of pink down the center of lower petals on a deep colored background which covers most of the lower petals. A very showy and fine variety. Each, 35c. Doz., \$3.50. $100, \$ 26.25$.

Silver Comet (1930. 77 days.) -Tall graceful plant with large widely expanded and gracefully recurved flower. Buds are the color of "Fern Kyle," but fully opened flower is a beautiful white with small fine pink lines on centers of lower petals and a slight faintly tinted cream background. A very pleasing and beautiful new white variety over five inches across and of fine texture. Each, 50c. Doz., \$5.00.

Snow Boy (1915. 76 days.)-Tall and stately; pure white. Many flowers open at a time. Often has only one beautiful blotch on lower petal. Large lower of finest form. Beautiful. Illustrated on page 47. Each, 10c. Doz., $\$ 1.00$. 100, \$7.50.

Snow Flake (1915. 71 days.) - A fine, all white, large flower on good plant, without any tint or markings. Awarded first prize for best pure white variety at A. G. S. show, Rochester, Aug., 1925. Each, 10c. Doz., \$1.00. 100, \$7.50.
Spangled Beauty (1930. 86 days.) - Tall graceful plant with six or more large perfect flowers open at a time. Color a fine dark rose pink, closely and finely flaked all over, giving the flowers almost a self color effect. Outer portion of lower petals somewhat deeper in color with considerably deeper rose red throat. Very showy and fine. An excellent variety. Each, 50c. Doz., $\$ 5.00$.

Spectrum Beauty (1930. 86 days.)-A fine medium height plant and good sized flowers, beautifully placed. Color a very striking tone of deep rose pink. Lower petals have large dark red blotches beautifully bordered soft creamy white. A very harmoniously blended variety. Each, 35c. Doz., \$3.50. $100, \$ 26.25$.

Spirit of 76 (1927. 83 days.)-Beautiful flower of deep vermilion-orange. Larger part of each lower petal covered with red lines interlaced with lines of white diverging from the center, giving the flower a decidedly attractive appearance. Artistic plant. Each, 20c. Doz., \$2.00. 100, \$15.00.

Splendor (1923. 68 days.)-A large, round flower of beautiful cardinal-red, approaching Lobelia in appearance. Very velvety, red. Each, 12c. Doz., $\$ 1.20$. 100, \$9.00.

Splendorra (1916. 73 days.)-Splendid, very dark wine-black. A fine, rich distinct sort. Illustrated on page 45 . Each, 8c. Doz., 80c. 100, \$6.00.

St. Thomas (1923. 78 days.) - Very large plant. Immense, showy, deep, salmon rose-red blooms. Pure, self-color upper petals, lower petals wonderfully blotched with showier blotches than "Pendleton." Blotches dark-red with blackish central bars. Extra showy and grand. Illustrated on inside front cover. Each, 12c. Doz., $\$ 1.20$. 100, $\$ 9.00$.

Stuart Merrill (1930. 68 days.)-Very tall and stately plant. Flowers very broadly expanded and "Recurved" petals very long, pointed and recurved like in a beautiful lily. Main color a delicate apple blossom pink of a beautiful flesh tone deepening considerably towards the outer portion. Lower petals very strikingly penciled and feathered rose red and white on a very dainty cream colored ground. Few, if any lilies more beautiful. Extra showy and fine. Each, 75c. Doz., $\$ 7.50$.

Sun Glow (1929. 80 days.)-A good height plant with very large flowers of purest self deep orange salmon color. Lower petals have a very fine red 
central bar with daintily penciled parallel lines and veinings of same color on a ground of beautiful golden yellow. On back of these flowers the yellow shown is a purest self which perfectly blends with the beautiful orange red ground color. Each, 35c. Doz,, \$3.50. 100, $\$ 26.25$.

Sun Rest (1930. 78 days.) - Tall stately plant with five or more very rich and very beautiful flowers open at a time. Color most vivid deep blood red. Large throat blotches much deeper velvety red. Mottled border of yellow extends beyond the blotches. This is another of those Gloxinia marked and colored varieties equal to an extra fine Gloxinia. Each, 50c. Doz., \$5.00.

Sunrise (1930. 82 days.)-Fine height and showy plant with large flowers. Flower, red mahogany with lower throat a brilliant glowing red. A distinct and showy garden variety of a decidedly rare color. Each, 35c. Doz., $\$ 3.50$. $100, \$ 26.25$.

Sweet Cherry (1930. 70 days.)-Fine showy tall plant and flower, five or more large flowers open at a time. Color of rich deep cherry rose, daintily flaked deeper. Much deeper cherry rose, velvety red over almost all of the lower petals, only lighter on outer portions. An unusually rich and stately appearance. Extra fine. Each, 50c. Doz., $\$ 5.00$.

Sweet Rose (1923. 76 days.)-Very massive flowers on tall, strong plant, of purest deep rose-pink with extra large, beautiful red throat. A wonder rose-pink. In the rose-pink class at the 1926 A. G. S. show, first prize was awarded this variety. At the same show a basket of Sweet Rose was used in connection with a basket of Helga, Tiger, Dr. Nelson Shook and Kunderd's Yellow Wonder and took the Executive Committee's Silver Cup. Illustrated on inside back cover. Each, 20c. Doz., \$2.00. 100, $\$ 15.00$.

Symbol (1930. 84 days.)-Tall plant and large flowers, very beautiful and elegantly placed on the spike. Color a perfect pure deep rose-pink. Lower petals a little deeper pure rose color. A fine rose-pink gladiolus and as beautiful in every way as can be imagined. Each, 75c. Doz., $\$ 7.50$.

Taro (1921. 75 days.)-Large flowers on strong spikes. American Beauty rosecolor. A new shade among gladioli. Each, 20c. Doz., \$2.00. 100, \$15.00.

T. A. Weston (1928. 79 days.)-Tall, stately, showy plants. Flowers beautifully placed and yery pleasing. Color purest deep salmon on rose-pink. Throat a very beautiful soft canaryyellow, very mellow and delicate. A refined and lovely flower in every way and for every purpose. Each, 35c. Doz., $\$ 3.50$. $100, \$ 26.25$.

Tiger (1926. 78 days.)-Mid-season. Tall, splendid plant with large, perfectly placed wide open flowers of remarkable tiger-like markings. Ground color of deep smoky-blue. Outer edges of petals of finest salmon-red flaking. Throat a beautiful red with outer portion of blotches white. Another of the sensations at the A. G.S. show, Rochester, Aug., 1925, and winner of a first prize. One of those unusual and very beautiful varieties which captivates at sight. A basket of this variety entered with a basket each of Dr. Nelson Shook, Sweet Rose, Helga, and Kunderd's Yellow Wonder won the Executive Committee's Silver Cup for the five best baskets of gladioli, A. G. S. National Show, 1926. Each, 20c. Doz., \$2.00. 100, $\$ 15.00$.

Tiger King (1930. 81 days.)-Large, fine plant and large flowers. Six to eight open at a time facing perfectly and very uniform. Dark maroon red, very heavily flaked with much darker maroon. A distinct and magnificent blotch of fiery red covers the width of the central one-third of lower petals and extending down the throat. It is deli-

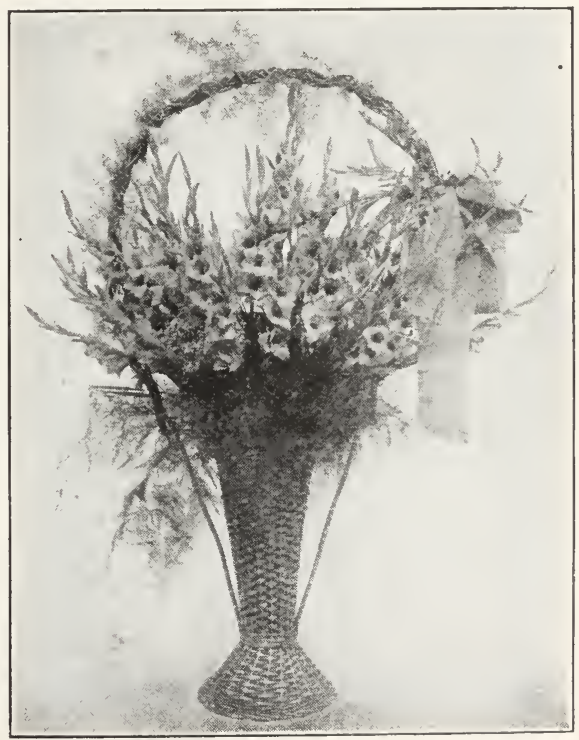

This imposing basket contains the variety Kunderd's Yellow Wonder. On the front page is shown this variety in natural color. The arrangement and color proved a delight to those who saw it at the National Gladiolus Show. 
cately and finely flaked white. Center of these blotches again has a dark vel= vety bird-like smaller blotch which extends outwardly in a subdued short white bar. Extending outwardly from the fiery blotch is another wide dark border. The whole flower is well entitled to the name of the Tiger King and is extremely striking and wonderful. Each, 75c. Doz., \$7.50.

Toledo (1929. 76 days.)-Tall strong vigorous plant with very large broad showy blooms all beautifully faced one way. Color of deep rich dark tyrian rose-red. Large showy deep red crimson throat blotches. Very showy and choice variety. Each, 50c. Doz., \$5.00.

Torpedo (1931)-Another of the new upright type or form. Color dark red with three inner or central petals blotched (neatly) with nearly a black red. Of a most distinct type, a type which no doubt, has a big future when it becomes better known and comes in a fine range of color varieties. Each, 25c. Doz., \$2.50. 100, \$18.75.

Trianon (1929. 66 days.)-Tall fine shapely plant with large flowers beautifully placed. Color is a deep rich pure salmon-pink with white central lines on three upper petals. Lower petals have almost crimson throat markings blending to delicate canaryyellow covering most of the petals. A very delicately colored and beautiful variety. Each, 35c. Doz., \$3.50. 100, $\$ 26.25$.

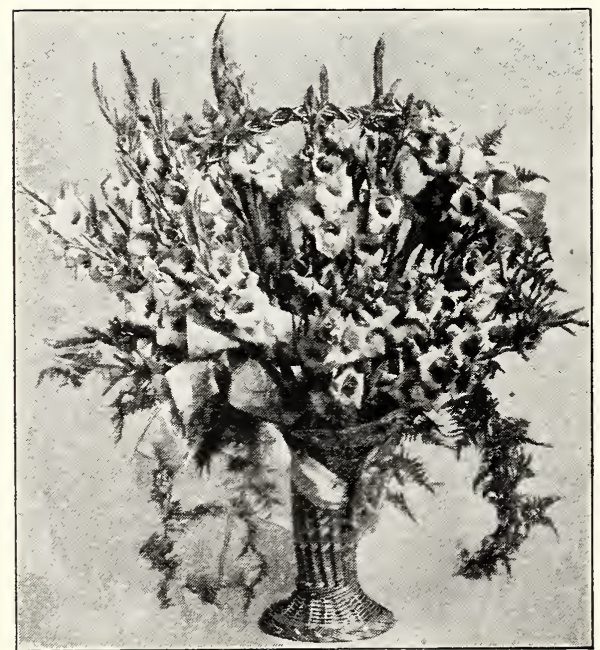

An exquisite basket of that lovely variety Sweet Rose. A few light, airy ferns were used as a filler. The basket was tied with a yellow ribbon. See color illustration on inside back cover.
Turkey Run (1930. 86 days.)-Fine strong plant with six or more very large and massive flowers open at a time. A little lighter in color than Marshall Foch and less ruffled, but more beautiful. Very distinct and massive in form and exceedingly showy and fine. Each, 50c. Doz., \$5.00.

Tyrian Beauty (1918. 85 days.)-A beautiful, large flower near "American Beauty" rose color. Grand. Awarded first prize for best plain petaled variety at the Mid-western Gladiolus Show, Des Moines, Sept., 1925. Each, 15c. Doz., $\$ 1.50$.

Tyrian Rose (1928. 79 days.)-Tall, fine plant with plenty fine, large, bright tyrian rose colored blooms open at a time. Flowers finely expanded and perfectly placed on an ideal stem. Upper throat lighter, lower throat a deeper, rich, velvety dark red. Showy and fine in every way. Each, 35c. Doz., \$3.50. $100, \$ 26.25$.

Uhlan Chief (1922. 69 days.)-Tall, graceful, slender spike. Flower of most intense brilliant vermilion-scarlet. Lower petals deeper color and beautiful, dark feathered. A magnificent red. Each, 8c. Doz., 80c. 100, $\$ 6.00$.

Ulysses (1916. 80 days.)-Large, round flower. Smoky-blue on rose-pink ground, deeper throat. Very attractive. Each, 10c. Doz., \$1.00. 100, \$7.50.

Velvet Diamond (1928. 79 days.)-Tall, stately, beautiful plant and spike. Flowers large, wide open, with upper central petal upright and curled back. All the petals are curled back and twisted much like a lily. Color richest, deep velvety, blood red with a brighter shade of red down the center of each. No more beautiful and showy red can be imagined. Extra grand and beautiful. Each, 75c. Doz., \$7.50.

Vermilion (1928. 97 days.)-A fine plant with a beautiful, deep orange or vermilion scarlet flower and plenty open at a time. Large, pure white throat blotches with a dainty suffusion of softest canary yellow on outer portion. A very beautiful gladiolus. Each, 15c. Doz., \$1.50. 100, \$11.25.

Viola Gem (1928. 79 days.)-Tall and stately plant with an outstanding and beautiful deep, dark bluish-green and perfect foliage. A good sized flower of a deep violet color and a dark, velvety red throat. An outstanding color in both flower and foliage. Very distinct and fine. Each, 20c. Doz., $\$ 2.00$. $100, \$ 15.00$.

Violet Prince (1927. 73 days.)-Fine plant with flowers perfectly placed on spike. Color almost black violet-red. 
Pure self-color excepting that the throat is somewhat of a deeper shade of the same color. Six and more blooms open at a time. An unusually fine, dark variety. Each, 20c. Doz., \$2.00. $100, \$ 15.00$.

Virginia Hale (1921. 84 days.)-Beautiful, soft creamy salmon-rose, deeper toward border of all petals. Very refined and beautiful variety. Each, 10c. Doz., \$1.00. 100, $\$ 7.50$.

Watermelon (1923. 75 days.) -Tall, fine plant. Large flowers, perfect form. Color a pure watermelon. As inviting and attractive as a beautiful watermelon. Unusually distinct and fine. Each, 12c. Doz., \$1.20. 100, \$9.00.

Wawasee (1927. 69 days.)-Very beautiful flower on fine spike. Color soft rose-pink, beautifully flaked all over with a clear, clean red. Elegant throat blotches of same color as the flakes but has deep crimson-red central bars veined white. A decidedly striking and beautiful garden and bouquet flower. Each, 15c. Doz., \$1.50. 100, \$11.25.

Weesie (1930, 82 days.) - Tall and very stately and graceful plant with six to eight or more very perfectly placed blooms open at a time. Color a deep salmon or shrimp-red of very richest appearance. Throat a little deeper on lower petals in a soft rose pink. General appearance decidedly rich, pure and distinct. Extra fine and beautiful. Each, 50c. Doz., \$5.00.

Western Star (1931)-Tall fine plant with plenty medium sized flowers open at a time. Color a dark rich orange red. Deeper on entire lower petals. These again have deep orange central bar or feather, and the edges of petals are a little lighter. A fine bright and showy orange colored variety. Each, 50c. Doz., $\$ 5.00$.

White Feather (1930. 90 days.)-Tall, stately plant and large showy white flowers beautifully placed. Lower petals have wide bars beautifully feathered. An unusually fine and beautiful white with a distinct and showy throat. Choice and fine. Each, 50c. Doz., \$5.00.

White Pigeon (1921. 70 days.)-Most wonderful, pure all white. Very large blooms, six to eight open. A strong, healthy grower and rapid propagator. Displayed in an unusually fine floral piece this variety was awarded first prize at the A. G. S. show, Rochester, Aug., 1925, A. G. S. bronze medal. In an equally beautiful double spray with "Peach Rose" was awarded another first prize, A. G.S. bronze medal. Winner of many other awards. Each, 12c. Doz., $\$ 1.20$. 100, $\$ 9.00$.

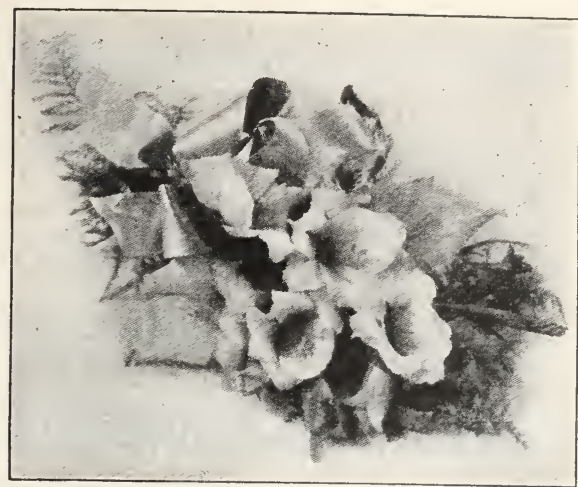

A Corsage Made with Gladioli

William Booth (1927. 78 days.)-Strong, massive plant. Very large flowers. Color a shade between tyrian rose and rhodamine-purple. Lower petals of much deeper rhodamine-purple clear to edges. Central bars on lower petals still deeper. The most outstanding gladiolus of this shade. Each, 20c. Doz., \$2.00. 100, $\$ 15.00$.

William Randolph Hearst (1931)-Tall showy graceful plant with many large and beautifully placed flowers open at a time. Color deep flesh coral pink over three upper petals, deepening on back of the flowers. Throat on lower petals of richest blushed soft cream canary-yellow, deepening toward ends with same flesh pink as the upper petals. No delicately colored rose or any other flower is more beautiful than this wonderful flower. Was extremely admired by all who saw it in bloom. Named in honor of the great publisher. Each, \$3.00. Doz., \$30.00.

Wonderful (1927. 89 days.)-Of all my introductions for 1927 this is the most gigantic plant of all. Blooms of a deep rose-pink. Upper petals much lighter in throat and central white bars. Lower petals have large, showy dark-red blotches with deeper dark-red bar in center, bordered white. Very attractive plant and flower. Splendid garden and cut flower variety. Don't miss this one. Each, 20c. Doz., \$2.00. 100, $\$ 15.00$.

\footnotetext{
W. E. Conrad, N. C. Feb. 16, 1931.

I have grown bulbs of all sorts and from many companies, but have never had better success with them than I have had with yours. Your bulbs are certainly the finest that I have ever seen and in the blooming season they merit praise from all who see them.

Mrs. G. H. Dietrich, N. Y.

Your catalog always brings me pleasure, and I spend literally hours pouring over it, even though I must limit my order each year to no though I must limit my order each year to no known Kunderd's, I have bought no others, and have always been well repaid.
} 


\section{Collection Offers \\ PLAIN PETAL VARIETIES}

These Collections Are All Sent with Each Variety Properly Labeled

Collection No. 22-All varieties valued up to and including 8c, 23 bulbs in all (value $\$ 1.84$ ) for.......\$1.65

Collection No. 23-All varieties valued up to and including 10c, 51 bulbs in all (value $\$ 4.64$ ) for.......\$4.20

Collection No. 24-All varieties valued up to and including 12c, 67 bulbs in all (value $\$ 6.56$ ) for...... $\$ 5.90$

Collection No. 25-All varieties valued up to and including 15c, 85 bulbs in all (value $\$ 9.26$ ) for.......\$8.35

Collection No. 26-All varieties valued up to and including 20c, 113 bulbs in all (value $\$ 14.86$ ) for.... $\$ 13.40$

Collection No. 27-All varieties valued up to and including 25c, 132 bulbs in all (value $\$ 19.61$ ) for.... $\$ 17.65$

Collection No. 28-All varieties valued up to and including 35c, 170 bulbs in all (value $\$ 32.91$ ) for.... $\$ 28.00$

Collection No. 29-All varieties valued up to and including 50c, 232 bulbs in all (value $\$ 63.91$ ) for.... $\$ 54.35$

Collection No. 30-All varieties valued up to and including 75c, 275 bulbs in all (value $\$ 96.16$ ) for.... $\$ 81.75$

Collection No. 31-All varieties valued up to and including $\$ 1.00$, 291 bulbs in all (value $\$ 112.16$ ) for... $\$ 95.35$

Collection No. 32-All varieties valued up to and including $\$ 2.00$, 299 bulbs in all (value $\$ 128.16$ ) for...\$108.95

Collection No. 33-All varieties valued up to and including $\$ 3.00$, 302 bulbs in all (value $\$ 137.16$ ) for...\$116.60

Collection No.34-Entire collection, one each of the 303 varieties listed (value $\$ 142.16$ ) for.... $\$ 120.85$

Varieties Included in These Collections Are Listed on Pages 34 to 65 


\section{Kunderd's Improved Primulinus Hybrids Unequalled for Floral Decorations}

The race of primulinus, as a whole, is regarded universally with great favor. Its sudden rise to popularity is phenomenal. Few flowers have risen from obscurity into prominence as rapidly as have the primulinus. This race of Gladioli contains the most delicate blendings of any. There are pastel shades among them that are really extraordinary and rival the finest of orchids. For home use, bridge parties, luncheons, their beauty is eagerly sought for in decoration. This race of Gladioli is suitable for any type of floral work. Here is the list of the finest that have yet been developed. Plant them in liberal numbers, and I am sure you will be well pleased.

Alice Tiplady (1915. 72 days.) - A grand large Primulinus of most beautiful orange-saffron color. Was awarded First-class Certificate of Merit by the North Shore Horticultural Society, Manchester, Mass., Summer of 1919. Winner of hundreds of awards. Very choice. Each, 8c. Doz., 80c. 100, $\$ 6.00$.

Altair (1916. 64 days.)-Extra tall, of finest salmon-saffron. A grand color. At the A. G. S. show, Rochester, N. Y., this variety won the A.G.S. Trophy for best corsage bouquet, also Trophy for best Plateau Basket. Winner of many other awards. Illustrated on page 68. Each, 8c. Doz., 80c. $100, \$ 6.00$.

Athene (1925. 86 days.)-Fine, salmon rose-red. A very beautiful and distinct variety. Each, 10c. Doz., \$1.00. 100, $\$ 7.50$.

Butterboy (1922. 66 days.)-An extra tall, strong plant and giant bulb. Large buttercup-yellow flowers, nicely spaced on spike. A decidedly distinct and showy Primulinus variety of much merit. This variety won first prize at A. G. S. show at Rochester, 1926, for best yellow. Each, 10. Doz., \$1.00. $100, \$ 7.50$.

Copper Bronze (1925. 74 days.) - A very striking copper bronze color. Very large flowers. Graceful in appearance as a vase flower. Strikingly unusual. Each, 20c. Doz., \$2.00. 100, \$15.00.

Dainty Orange (1928. 72 days.)-Tall, slender, graceful spike with many small to medium sized flowers open at a time. Flowers perfectly placed and slightly spaced giving spikes a decided

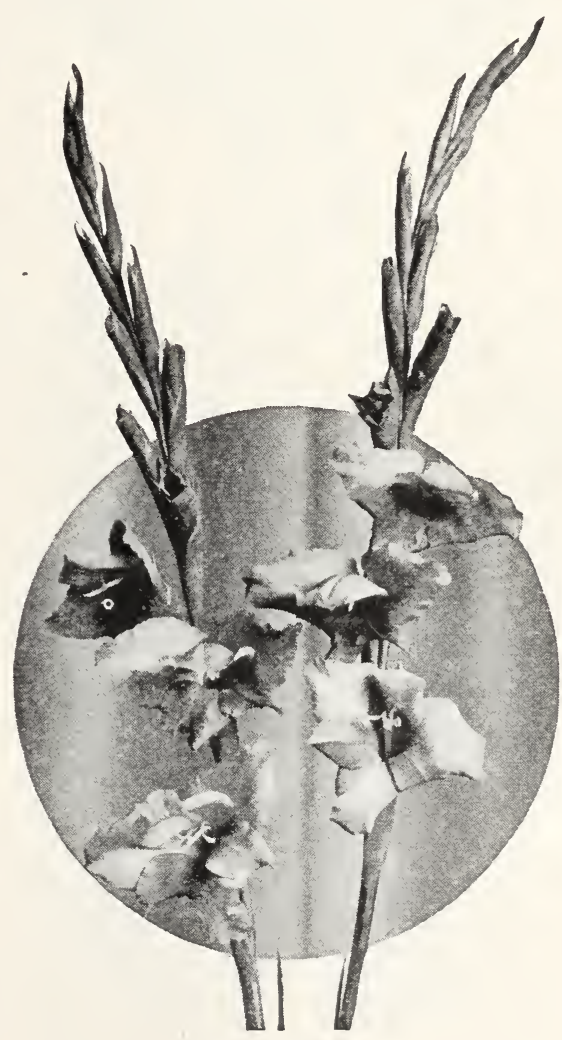

ENCORE

Described on Page 68 
and attractive appearance. Ends of all petals of bright, light orange color while upper throat and back of petals is of a very rich, deep orange color. The whole flower is a beautiful glowing orange in effect and very beautiful on the plant or in floral work. Each, 25c. Doz., \$2.50. 100, $\$ 18.75$.

Enchantress (R-1926. 75 days.) - A Grandiflora Primulinus. Medium large flowers of daintiest, soft shrimp-pink. Throat of faintest, soft cream-white, slightly penciled pink. A most excellent variety. Each, 15c. Doz., \$1.50. $100, \$ 11.25$.

Encore (1929. 58 days.)-Good height plant with very beautiful canary yellow upper petals, and lower petals of purest daffodil yellow over almost entire petals excepting lighter towards the ends. Illustrated on page 67. Each, 25c. Doz., \$2.50. 100, \$18.75.

Evening (R-1927. 69 days.)-Grandiflora Primulinus - Tall, slender, graceful plant. Five to six very dainty, soft flesh-pink colored blooms open at a time. Throat a very dainty, soft

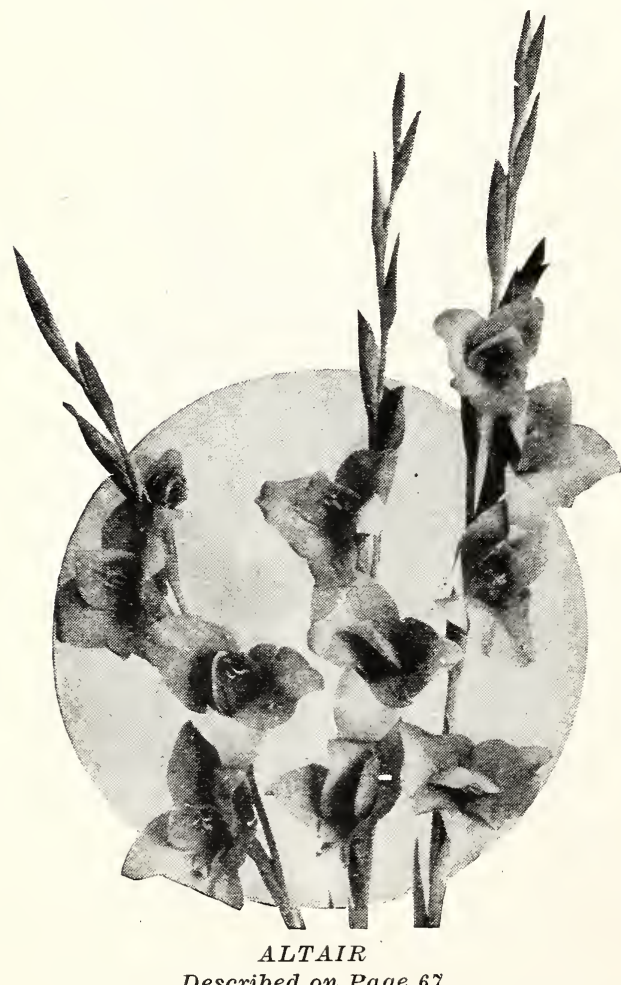

Described on Page 67 canary-yellow of purest tint. Exceedingly fine. Each, 20c. Doz., $\$ 2.00$. 100, $\$ 15.00$.

Golden Arc (1928. 72 days.) - Fine, medium height plant with four and more grand, large beautiful, light orange colored flowers open at a time. Lower petals a deep, pure, golden daffodil yellow except ends which are the same color as upper petals. The whole effect is a rich, golden orange. Extra grand. Each, 35c. Doz., \$3.50. 100, \$26.25.

Golden Frills (R-1925. 66 days.) -A large and open flower. Deep, rich daffodil-yellow with slight pink lines on lower petals. Intensely ruffled and very choice. Beautiful tips of this variety arranged in a bowl and shown at the A. G. S. show, Rochester, Aug., 1925, awarded first prize for "best display of gladiolus tips in bowl," A. G. S. Trophy. Each, 25c. Doz., \$2.50. 100, $\$ 18.75$.

Golden Gleam (1922. 74 days.)-Tall, very large and open Primulinus of lighter shade than "Alice Tiplady." More orange color. Extra. Each, 8c. Doz., 80c. 100, $\$ 6.00$.

Golden Harmony (1928. 69 days.)-Tall, slender, graceful spike with many very neat ruffled blooms open at a time prettily placed. Color of upper petals fine canary yellow. Lower petals deeper rich canary or daffodil yellow with deeper central golden narrow bars. Each, 20c. Doz., \$2.00. 100, $\$ 15.00$.

Golden Light (1928. 71 days.)-Fine, handsome spike with very large flowers. Color a soft, deep sulphur yellow upper petals; lower petals a very rich deeper yellow. The two colors very perfectly blended. A first class florists' variety as well as a very fine garden flower. Each, 50c. Doz., \$5.00.

Golden Orange (1927. 67 days.-Grandiflora Primulinus)--The name describes it. Tall, fine spike with beautifully formed flowers of good size. Perfectly placed on spike. Color of a beautiful golden or soft orange tone. Self-color. Back of flower deeper shade of same color. Almost like gold. Extremely rich and beautiful. Each, 35c. Doz., $\$ 3.50$. 100, $\$ 26.25$.

Golden Tinge (1923. 70 days.)-Fine stem and plant. Very dainty, orangesalmon flowers, deepening toward ends of petals. Lower petals deep-yellow with beautiful golden throat lines. A very beautiful throat and a grand variety in every way. This variety displayed in a basket with "White Butterfly" at the A. G. S. show, Rochester, Aug., 1925, won first prize, A. G. S. bronze medal. Each, 8c. Doz., 80c. 100, $\$ 6.00$. 
Hoosier Pearl (1927. 69 days.) - A superb variety. (Grandiflora Primulinus) Tall, fine plant, flowers medium size, perfectly placed. Throat purest, soft pastel-yellow on lower petals, blushed pink toward outer edges. Upper petals dainty pink. The entire effect is dainty apricot making it a very pleasing variety. Increases fast and makes two and more spikes from each bulb. An outstanding gladiolus which will no doubt become very popular. Stock yet very small. Each, 20c. Doz., \$2.00. 100, $\$ 15.00$.

Jap (1927. 67 days.) - A large, fine shaped bloom on fine spike of good height. Flowers well expanded and beautifully placed on spike. Color a most refined and beautiful tone of lemon-yellow. Self-color. Must be seen to be appreciated. (Grandiflora Primulinus.) Each, 35c. Doz., $\$ 3.50$.

King of Oranges (1927. 79 days.)-A large showy Grandiflora Primulinus variety of an intense deep orangesaffron color. Much like the popular variety, Alice Tiplady, but much deeper color and finer. Sure to become a winnør. Each; 20c. Doz., \$2.00. 100, \$15.00.

Leen Wone (1927. 62 days.)-(Grandiflora Primulinus)-An extraordinary, pure, deep, self-colored orange. Five or more perfectly shaped blooms open at a time. Medium sized flowers. Very lasting as a cut flower. Nothing so fine in pure orange color has ever been placed on sale. Small stock. Each, 12c. Doz., \$1.20. 100, $\$ 9.00$.

Lullaby (1928. 66 days.) - A light orange yellow with a wider border of deeper orange red on ends of all the petals. Throat a deeper yellow than the upper petals. Very pleasing and attractive. Each, 25c. Doz., \$2.50. 100, \$18.75.

Marigold (1926. 80 days.)-Midseason. A giant Grandiflora Primulinus of most beautiful, deep canary-yellow. Lower petals deeper with slight pencilings. Flowers very large and widely open. Lightly ruffled. One of the most striking and beautiful Primulinus yet produced. Illustrated on inside back cover. Each, 20c. Doz., \$2.00. 100, \$15.00.

Ming Toy (1922. 71 days.) - Very large flower of finest form. Showy, deep buff-yellow throat. Tall plant. A sensation at the North Shore Horticultural Show at Lake Forest, Ill. This variety, combined with Golden Frills, was awarded the A. G.S. Trophy for the best hamper of Gladioli at A. G. S. show, Aug., 1926. Also winner of many other awards. Each, 10c. Doz., \$1.00. $100, \$ 7.50$.

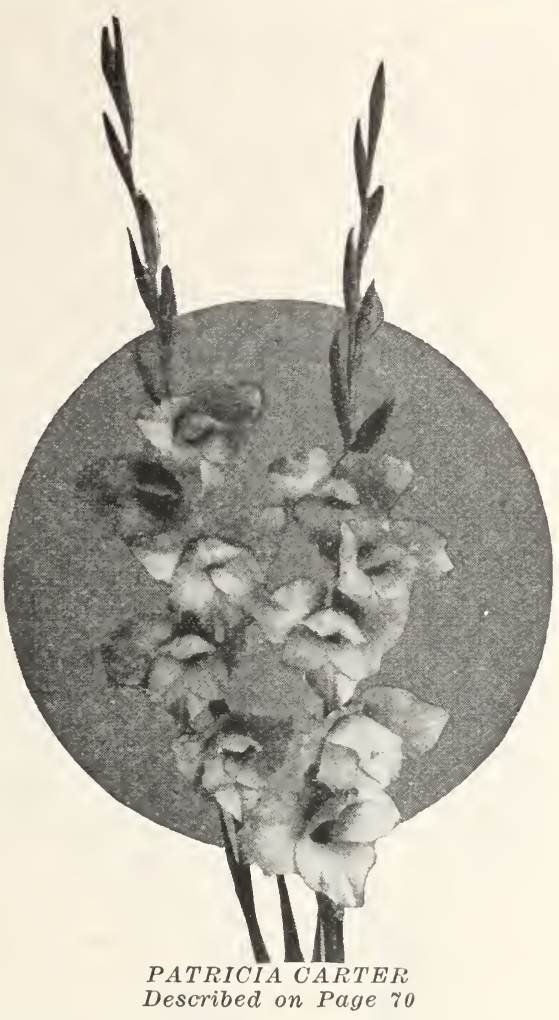

Mongolia (1928. 74 days.)-Very tall, stately plant. Large Primulinus $\mathrm{Hy}-$ brid with flowers perfectly placed and beautifully spaced. Color of intense daffodil yellow, a little deeper in throat but as near a perfect self as any. Five or more very large (for a Primulinus) flowers open at a time. I believe this is the deepest yellow and finest yellow Primulinus Hybrid to date and no doubt will become very popular both as a garden favorite and a florist's flower. Each, 25c. Doz., \$2.50. 100, $\$ 18.75$.

Mrs. Calvin Coolidge (1927. 66 days.)A superb Grandiflora Primulinus. Fine plant and large flowers. Color of finest deep flesh or salmon rose pink. Lower petals of a soft creamy-yellow tint, bordered same shade of pink as the upper petals. Border of all petals has a very slight white line adding materially to its attractiveness. Unsurpassed in its class. Named by special permission from President Coolidge. This beautiful new introduction won an A. G. S. award of merit as the best new seedling variety in the Primulinus Grandiflora class at A. G. S. show, Rochester, 1926, and easily won as the 
most outstanding variety at the A. G. S. show, Toledo, 1928. Each, 50c. Doz., $\$ 5.00$.

Oh Promise Me (1930. 60 days.)-Very tall and stately plant with lovely "Prim." flowers. Spaced openly on spikes giving the effect of beautiful butterflies airily poised on the stems. Widely expanded and open. Color and upper petals of richest flesh tone, deepening towards the edges. Lower, a pure, clear delicate cream with ends of same color as upper petals. Six or more of these daintily colored and beautiful butterfly like flowers open at a time. Hardly surpassed by any other "Prim." hybrid in color or artistic beauty. Specially fine for corsages and brides' bouquets. Each, 75. Doz., \$7.50.

Orange Giant (1931.) - Tall, strong sturdy plant with giant "Grandiflora Prim." flowers. Three to five open at a time. Color most intense pure deep fiery orange over all petals. Inner portion of throat on lower petals of deep fiery orange red. A mammoth and altogether outstanding rich orange color. Unusually distinct and showy. Very extra in this class. Each, 50c. Doz., $\$ 5.00$.

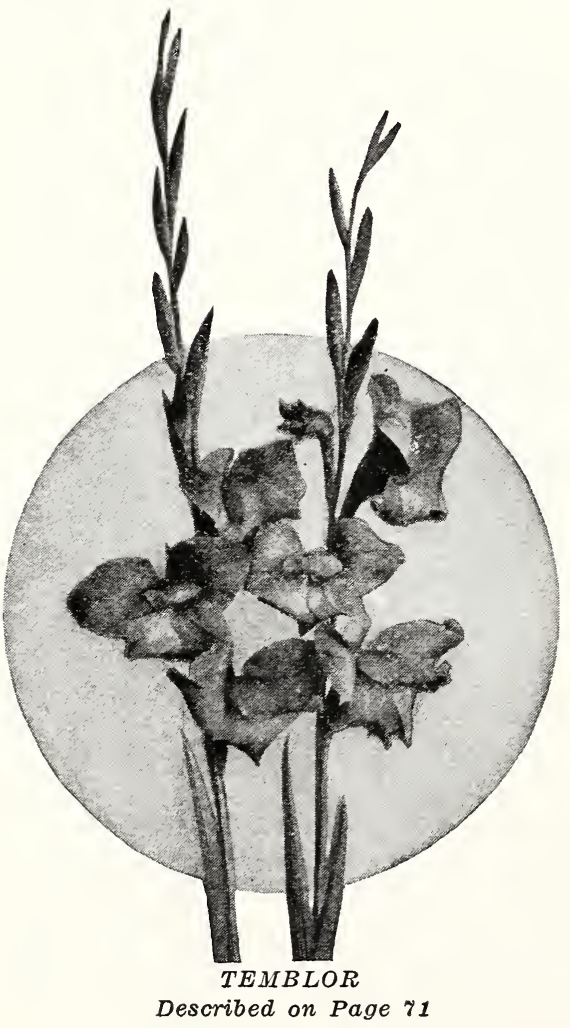

Orange Salmon (1931.)-Tall slender graceful stem. Flowers medium size of very distinct Primulinus form and color of a glowing orange with clean, clear, large rich pure yellow throat. One of the best of all Primulinus varieties. Each, 25c. Doz., \$2.50. 100, $\$ 18.75$.

Pasteline (1928. 71 days.)-Tall, elegant plant and foliage. Four to six beautifully placed, good sized blooms open at a time. Color, upper petals a decidedly deep, soft creamy yellow. Lower petals a beautiful golden yellow as fine as the finest daffodil. An extra fine Primulinus Hybrid. Each, 15c. Doz., \$1.50. 100, $\$ 11.25$.

Patricia Carter (1926. 71 days.)-(Primulinus Grandiflora.) Tall, fine plant, rugged in -its growth and beautiful. Tall spike with five and six perfectly placed flowers open at a time. Large bulbs average three and four spikes. Flowers are of most beautiful tone of softest, light shrimp-pink color. No markings. The most beautiful Primulinus I have ever offered to my customers and one which is destined to become very popular. Named in honor of the little granddaughter of Dr. F. E. Bennett, so widely known among lovers of the gladiolus and one of the world's largest amateur gladioli growers. Illustrated on page 69. Each, 35c. Doz., $\$ 3.50$. $100, \$ 26.25$.

Phyllis Cloetingh (1930. 64 days.)-Tall stately plant and good sized well open flower for a Primulinus Hybrid. Color of clearest salmon rose over entire six petals excepting a large throat of a soft canary-cream with central bars of a lighter yellow extending beyond the blotches. A decidedly distinct, lovely and beautiful flower. Each, 50c. Doz., $\$ 5.00$.

Ramona (R-1918. 75 days.)-Dainty yellow. Golden throat. Beautifully ruffled. Each, 8c. Doz., 80c. 100, $\$ 6.00$.

Red Orange (1929. 76 days.)-Tall strong graceful plant, a grand, showy giant Primulinus. Color a deep orange red with beautiful central bars of deeper red, elegantly penciled on a beautiful soft yellow ground. Very beautiful for basket and all kinds of decorative work. Each, 35c. Doz., \$3.50. 100, $\$ 26.25$.

Saffron King (1928, 76 days.) - A very large Primulinus Hybrid of a rich saffron orange color beautifully flaked a deeper orange, rich golden yellow with clear throat blotches of beautiful form and in perfect contrast with the main color. A decidedly fine orange Prim- 
ulinus Hybrid and very showy and beautiful. Each, 25c. Doz., \$2.50. 100, $\$ 18.75$.

Salmon Buff (1922. 88 days.) - A good height spike with very large flowers of beautiful salmon-buff. Throat fine yellow, beautifully penciled. Illustrated on page 56. Each, 10c. Doz., \$1.00.

Shell Pink (1921. 73 days.) - Tall, largeflowered, rose-pink with beautiful slightly mottled white throat. Very choice. Winner of many awards. Each, 8c. Doz., 80c. 100, $\$ 6.00$.

Stippled Beauty (1928. 66 days.)-Tall, graceful plant. Large and showy flower of beautiful, deep salmon rose pink flaked a deeper rose red shade. Lower petals, all but ends, very beautifully penciled. Stippled a beautiful yellow and red. A very showy and beautiful Primulinus Hybrid. Each, 12c. Doz., \$1.20. 100, \$9.00.

Sweeter Seventeen (1927. 85 days.)(Grandiflora Primulinus)-Large flowers on tall strong plant. Distinct in appearance. Cleanest, clear, deep salmonpink. Throat, dainty pastel-yellow. Lower petals creamy-yellow; excepting at edges it is salmon-pink as upper petals. Excellent spike for cutting and otherwise very fine. Each, 35c. Doz., $\$ 3.50$. 100, \$26.25.

Syncopation (1928. 72 days.)-Large Primulinus on a tall, fine plant. Flowers beautifully placed and intensely ruffled. Broad, wide open upper petals and light lemon in color. Lower petals deepest canary or deep daffodil golden yellow with a beautiful narrow pencil line of red on midrib or central bars. Each, 15c. Doz., \$1.50. 100, $\$ 11.25$.

Taurus (1925. 67 days.)-A beautiful Primulinus Hybrid of a fine purple or purple-violet color. Distinct, rare and fine. Displayed in a beautifully arranged basket with "White Butterfly" at A. G. S. show, Rochester, Aug., 1925, won first prize, A. G. S. bronze medal. Each, 10c. Doz., \$1.00. 100, \$7.50.

Temblor (1926. 73 days.) - A giant Grandiflora Primulinus. Tall, graceful spike. Five and six blooms open at a time. Color wonderful, clear salmonred, deeper towards outer edge of petals. Throat of purest, soft creamywhite. Elegant. Illustrated on page 70. Each, 15c. Doz., \$1.50. 100, \$11.25.

Today (1926. 77 days.)-A Grandiflora Primulinus. Large flower of grandest salmon-orange. Throat dainty, soft yellow. Flowers beautifully opened with petals recurved as elegantly as a very beautiful lily. Each, 12c. Doz., $\$ 1.20$. $100, \$ 9.00$.

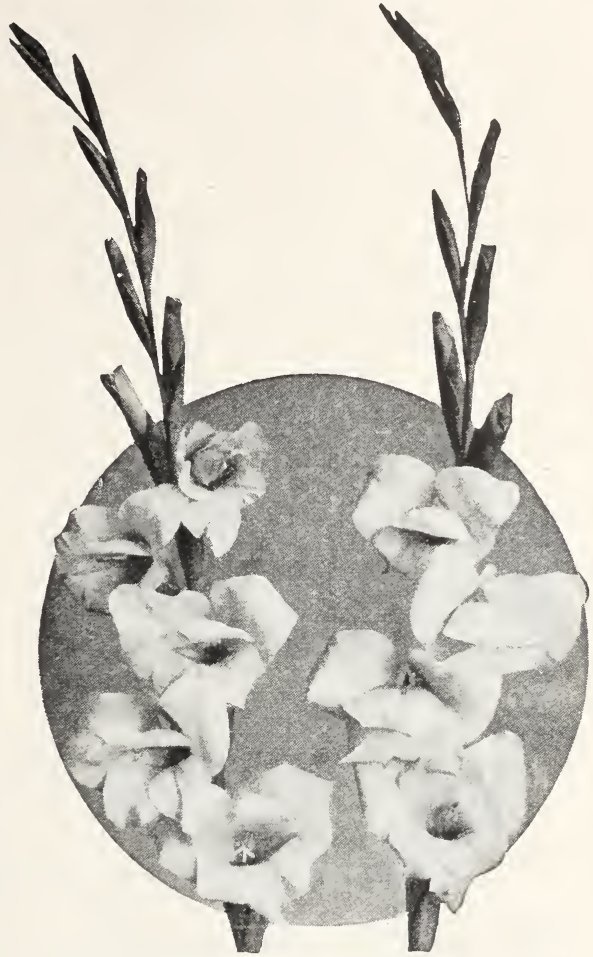

WHITE BUTTERFLY

Described on this page

Ulrica (R-1918. 80 days.)-A wonderfully choice, rich yellow overspread lightly orange. Large flowers and very attractive. Each, 8c. Doz., 80c. 100, $\$ 6.00$.

Varro (1929. 69 days.)-Tall slender graceful plant with medium size flowers very beautifully spaced on the spike. Main color is a soft old rose tint slightly lavender. Throat is a beautiful cream with very narrow pencil line through center. A very refined and showy flower. Each, 20c. Doz., $\$ 2.00$. 100, $\$ 15.00$.

Virginia Lou (1926. 78 days.)-Mid-season. A giant Grandiflora Primulinus. A widely open flower of large size. Color rich, old-rose pink, throat of daintiest, creamy-yellow with slight pink pencilings deep in throat. An extra grand and beautiful cut flower variety. Each, 12c. Doz., \$1.20. 100, $\$ 9.00$.

White Butterfly (1922. 70 days.)-A first-class all-white with soft, creamwhite throat. Fine, slender stem and beautiful cut flower. Exceedingly popular at the A. G. S. show, Roch- 
ester, Aug., 1925. Displayed in a basket with" "Golden Tinge," won first prize, A. G. S. bronze medal. In a funeral basket with "Blanche Bollinger" and "Elba," won first prize, A. G. S. Trophy. In another basket with "Taurus," first prize, A. G. S. bronze medal, and at the same show took first prize for the best white Primulinus Hybrid. In 1926 first prize was again awarded this variety for best white in Primulinus class. Illuistrated on page 71. Each, 10c. Doz., \$1.00. 100, $\$ 7.50$. Wonderland (1930. 78 days.) - A very tall and showy plant with very large Prim. Hybrid flowers of richest orange color. Fine large mellow deep orange red throat which has a slight and subdued soft primrose yellow central line extending down the center. A giant, showy and fine Primulinus Hybrid of striking appearance. A rich and rare color among Gladioli. Each, 50c. Doz., $\$ 5.00$.
Yellow Frills (R-1930. 83 days.)-Tall, slender, graceful plant with plenty of large flowers in bloom at a time. Flowers widely opened and not hooded. Color, rich, clear, deep canary-yellow all over, only slightly deeper on lower petals. Splendidly ruffled. Ideal in type, color and in every way a beauty. Extra fine. Each, 50c. Doz., \$5.00.

Zona (R-1927. 67 days.)-(Grandiflora Primulinus)-Attractive plant. Deep salmon-rose color. Lower petals rich deep canary-yellow, outer portion a lighter shade of the main color. Deep rose-pink blotches on center of lower petals. A fine flower in every way and sure to please. Blooms of this variety were used in making the prize winning bride's bouquet at the A. G. S. 1926 show, A. G. S. Trophy. An award of merit was also given this variety for the best seedling Primulinus Grandiflora type. Each, 15c. Doz., \$1.50. 100, $\$ 11.25$.

\section{COLLECTION OFFERS OF PRIMULINUS HYBRIDS}

These Collections Are All Sent with Each Variety Properly Labeled Varieties Included in These Collections Are Listed on Pages 67 to 72

Collection No. 35-All varieties valued up to and including $8 \mathrm{c}$, 7 bulbs in all (value $56 \mathrm{c}$ ) for........\$0.50

Collection No. 36-All varieties valued up to and including 10c, 13 bulbs in all (value $\$ 1.16$ ) for......\$1.05

Collection No. 37-All varieties valued up to and including 12c, 17 bulbs in all (value $\$ 1.64$ ) for......\$1.50

Collection No. 38-All varieties valued up to and including $15 \mathrm{c}$, 22 bulbs in all (value $\$ 2.39$ ) for..... \$2.15

Collection No. 39-All varieties valued up to and including 20c, 29 bulbs in all (value $\$ 3.79$ ) for...... \$3.40

Collection No. 40-All varieties valued up to and including 25c, 36 bulbs in all (value $\$ 5.54$ ) for...... $\$ 5.00$

Collection No.41-All varieties valued up to and including 35c, 42 bulbs in all (value $\$ 7.64$ ) for......\$6.90

Collection No. 42-All varieties valued up to and including 50c, 48 bulbs in all (value $\$ 10.64$ ) for.....\$9.60

Collection No. 43-Entire Collection, one each of the 49 varieties listed (value $\$ 11.39$ ) for.........\$10.25 


\section{Laciniated Gladioli Kunderd's Latest Creation}

Imagine Gladioli so perfect that you would think a fairy had cut them out with a small pair of scissors, painted and twisted the petals in most unusual and artistic shapes, then you will have a mental picture of the Laciniated Gladioli. This is a race which I originated and which is very different from all the others. A bouquet of Laciniated Gladioli is an object of rare beauty. They are especially desired for delicate floral work. If you desire flowers which are outstanding and rare, be sure to include varieties from this group.

Adair (1929. 62 days.)-Fine height slender plant. Flowers have beautiful recurved and twisted petals, nicely laciniated. Upper petals are creamywhite and lower petals a dainty soft canary-yellow. A very dainty and beautiful variety of this new type. A dainty beauty. The daintiness and gracefulness of the laciniated varieties make them very popular for basket work. Each, \$1.00. Doz., \$10.00.

Hyperion (1928. 60 days.)-Fine, tall plant deep orange-scarlet or vermilion. Lower petals deeper orange. Very graceful irregular petals. Entire flower, all the petals, bordered daintily with a clear, narrow line of yellow. Back of flowers finely stippled and beautifully penciled orange-yellow. A very showy flower in this new race and larger than "Lacinatus." Each, 75c. Doz., $\$ 7.50$.

Impresario (1928. 87 days.)-This is Kunderd's largest and grandest Laciniated. Color, upper petals a beautiful, mellow, light, clear lemon-yellow. Lower petals most beautiful canaryyellow with very delicate central narrow line of golden yellow which is a soft pink in some of the flowers. A very wonderful flower of most wonderful orchid-like appearance and a fine seed producer. Well worth $\$ 100.00$ to the breeder. Scarce. An attraction for your garden. Each, $\$ 3.00$. Doz., $\$ 30.00$.

Interlude (1928. 69 days.) $-A$ good tall plant and a large flower of light yellow-deeper yellow on lower petals. Five or more perfectly placed flowers open at a time. Rapid multiplier. Sometimes more laciniated in some flowers than in others. Each, 50c. Doz., $\$ 5.00$.

Lacinatus (1923. 69 days.)-The forerunner of another new Kunderd race of gladioli. Beautiful rose-pink and under good culture will reach the size of $3 \frac{1}{2}$ inches to 4 inches in diameter. Spike is slender, graceful and of good height. Very artistic and especially adapted for fine floral work in dainty decora-

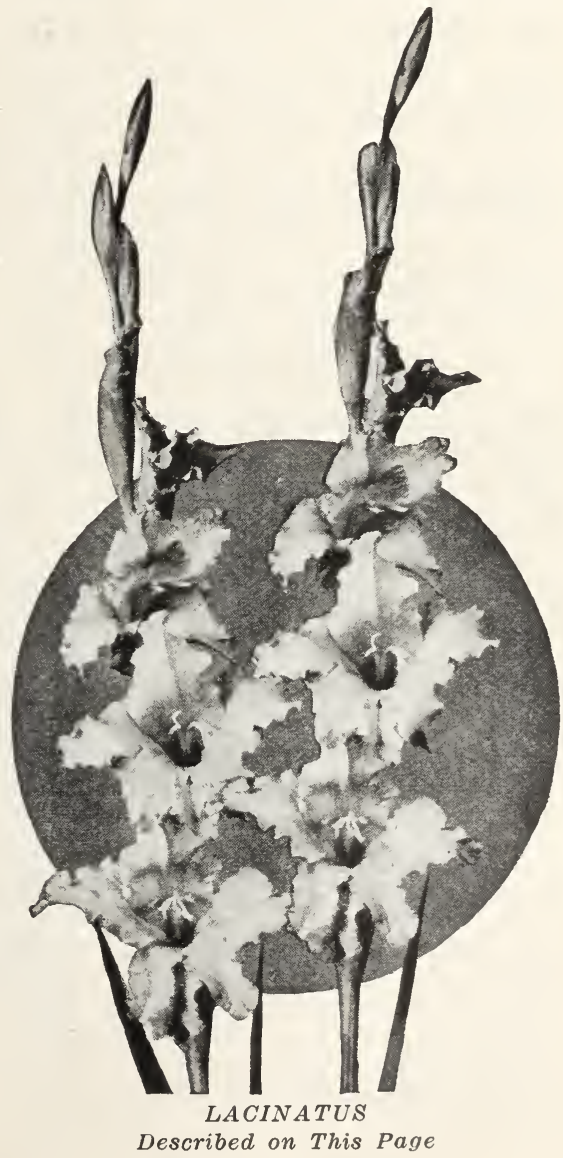

Described on This Page 
tions. A dainty thing when forced on the greenhouse bench, and as it is a most artistic gladiolus it is certain to become a very popular variety when the stock is once in sufficient supply. A large size bulb will produce four and five spikes of blooms. Illustrated on page 73. Each, 20c. Doz., \$2.00.

Lavender Beauty (1927. 69 days.)Pinkish lavender, flaked deeper lavender. Lower petals a little lighter in throat with slight throat markings and narrow central lines. Nice, slender plant. A worth-while addition to the laciniated type. Each, 25c. Doz., \$2.50. $100, \$ 18.75$.

Little Doll (1931)-Tall fine plant with small widely expanded and well lacini- ated flowers. Color pale creamy-white on upper petals. Lower petals soft creamy-yellow neatly striped, and feathered brownish-pink. A neat new laciniated variety. Each, 50c. Doz., $\$ 5.00$.

Pierian (1928. 70 days.)-Tall, slender and graceful plant with six or more finely spaced flowers open at a time. Upper side petals very upright, bird's wing like, and central upper petals very hooded giving the flower quite an orchid-like appearance. Color of upper petals soft canary-yellow, lower petals deeper canary-yellow with only a very narrow thread line of pink brown down the center. Sometimes more laciniated than others. Each, 50c. Doz., $\$ 5.00$.

\section{COLLECTION OFFERS OF LACINIATED VARIETIES}

Varieties Included in These Collections Are Listed on Pages 73 and 74

Collection No. 44-All varieties valued up to and including 50c, 5 bulbs in all (value $\$ 1.95$ ) for....... $\$ 1.75$

Collection No. 45-All varieties valued up to and including $75 \mathrm{c}$, 6 bulbs in all (value $\$ 2.70$ ) for....... $\$ 2.45$

Collection No. 46-All varieties valued up to and including $\$ 1.00$, 7 bulbs in all (value $\$ 3.70$ ) for........\$3.35

Collection No. 47-Entire collection, one each of the 8 varieties listed (value $\$ 6.70$ ) for...........\$6.05

These Collections Are All Sent with Each Variety Properly Labeled

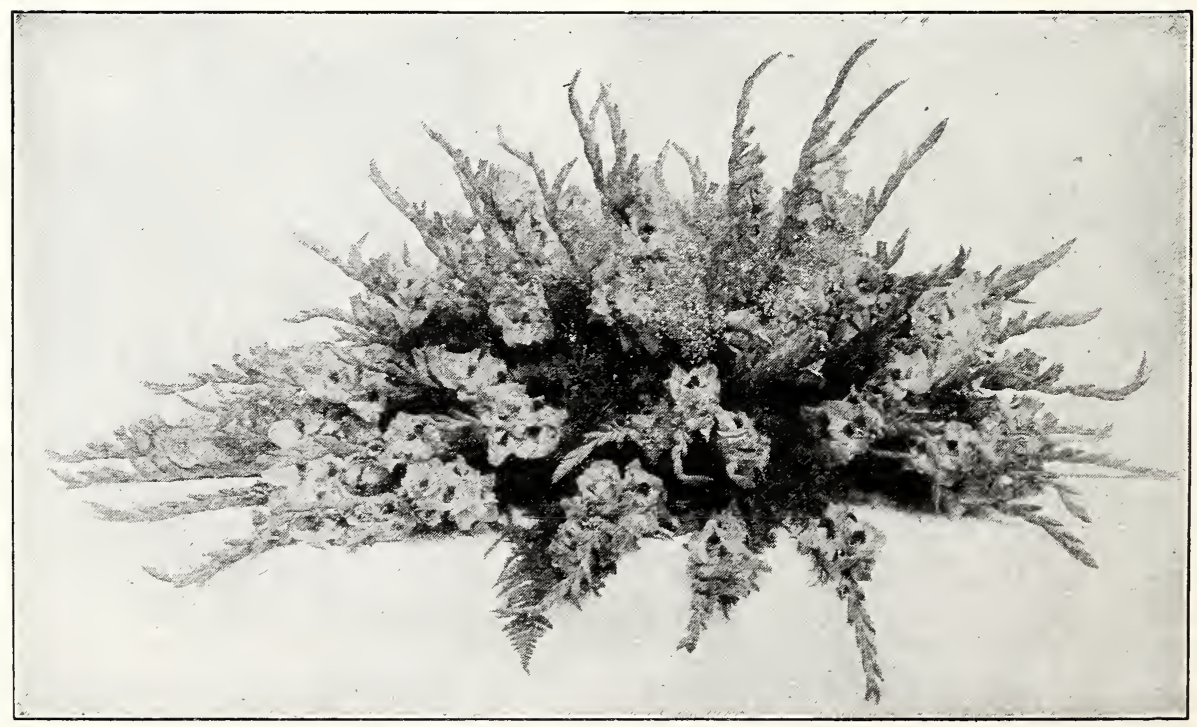




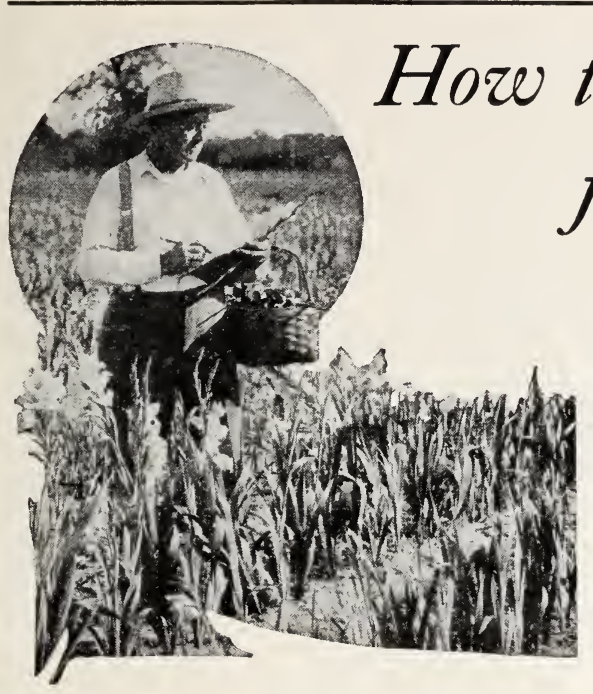

TLOWER lovers everywhere are filling their gardens with beautiful Gladioli and are adding the newer and finer things each year. Many business men and women are bringing together large collections and are making the Gladiolus their principal garden attraction.

Gladioli are easy to grow and are the most adaptable of all garden flowers. Nothing else of their class costs so little or blooms so readily, in any soil and every climate. Their blooming season is long and their color varieties are literally unlimited.

The ease of culture, and their comparative freedom from diseases and insect enemies, make the Gladiolus, without doubt, the most satisfactory flower to grow, even by the most inexperienced, and no other flower gives so great and so certain returns for the same amount of labor and effort.

The bulbs you buy can be used for years to come and the comparatively few hours devoted to their growing will be considered a "labor of love" by all who cultivate them, because they will be repaid so many times over for the little effort required. Grow at least a small collection selected from the extensive list I offer you here and you will be most enthusiastic about your experience. Your success will be greatest if you follow the simple suggestions about planting, care and storage explained here:

Selecting the Stock: First of all it is necessary to begin with good bulbs (corms) of good varieties. This does not necessarily mean the most expensive, as many of the moderate priced ones are among the best, their price being lower simply because they are more plentiful.

\section{to Plant and Care} Gladioli

Gladioli are universally successful in every section of this country while many other flowers can only be satisfactorily grown in certain localities. In the Northern States blooms can be produced from late June and early July until hard freezes begin; often very late in the fall. In the Southern States, in California and elsewhere, the season of course begins earlier and extends almost into the winter of the North.

Soil Suggestions: Any good garden soil is suitable. If of a clayish or heavy composition it can be mellowed by addition of sand, sandy loam, muck, etc. In preparing the soil it is necessary to follow only such methods as would give you a fine crop of garden vegetables.

Where to Plant: It should be remembered that Gladioli enjoy sunshine and should not be planted in very shady places. Plant in rows or beds, in borders or among shrubbery, roses, etc. Plant in separate groups or among other flowers and plants. Plant marigolds, zinnias, asters and other flowers among your Gladioli as well as Gladioli among other flowers and plants, and you will discover many possibilities for delightful effects. I would appreciate reports of your experiments as such information may prove valuable to others growing Gladioli.

Location and Preparation of the Soil: It is of advantage, when possible, to use new location or soil each season so that bulbs are not planted more often than every second or third year in the same soil. Spade in a good covering of manure in the fall preceding the planting. The richer the soil and the better the care and culture the better the results will be. In the spring, when the soil is in proper condition, spade deep and pulverize thoroughly.

Planting: Planting should begin as soon as early garden-making will permit and be followed by successive plantings, of say ten-day intervals, until early June in our Northern States and later in the South or they may all be planted at one time. For particularly late blooms they may even be planted as late as July first in the North. The later plantings bloom in a shorter period after planting because of the warmer weather and better ground conditions. This applies to all 
climates and countries. Also the larger bulbs of equal quality come into bloom a little sooner than the smaller ones. The smaller bulbs may not produce as large spikes but the individual blooms will generally be as large and, if of high quality to begin with, will be more valuable over a period of years and give a much larger increase in new bulbs and bulblets.

Depth of Plant: Bulbs may be planted four inches deep or over in mellow soil, and four to eight inches apart in the row. Rows should be eighteen inches to two feet apart. They will, however, stand closer planting if the space is limited. While deeper planting will help to keep plants from falling over at blooming time they should be staked to protect them against heavy winds.

Fertilizing and Feeding the Soil: When planting, use only well rotted manure or high-grade potato fertilizers. Liquid fertilizer or prepared sheep manure may be applied to the soil near the rows, once every ten to twenty days, care being exercised not to make applications too strong. Frequent, thorough waterings of the soil in the evening is a wonderful stimulant and gives the blooms much greater sun resistance and lasting qualities. Prepared, ground bonemeal, or a high-grade potato fertilizer can be sprinkled over the soil near the plants, between rows, and raked in to good purpose. Nitrate of Soda (a tablespoonful to two gallons of water for each dozen plants), applied to the soil near the rows once each week or ten days after buds begin to show color is very beneficial. Or you can sprinkle the pulverized nitrate of soda over soil, rake in, and water.

Cultivations: Keep the soil well and frequently worked, especially early the next forenoon after watering the previous evening. Water thoroughly at intervals of several days. Excepting in exceedingly dry periods do not water daily. Over-watering is an injury. Keep soil crust from forming in the rows among the plants. After blooms begin to show, cultivate the soil to a lesser depth. Do not work the soil when wet.

A Good Thing to Remember: The three greatest essentials to successful growing of Gladioli, as of most everything else, are-good soil, good and frequent cultivation and plenty of water. When plants begin to ripen, watering should be lessened.

Staking: Slender stakes of light wood or bamboo painted light green make good supports for the spikes at blooming time. When horizontal lines are used they should be fastened to end posts firmly set, and wires tightly stretched. A few more stakes should also be placed at intervals along the lines. Use strips of cloth instead of cords to tie blooming spikes to their supports.

Marking: Painted white pine labels, copper wired, are very suitable for marking plants. As an accommodation to my customers I will supply such painted labels, with bulb orders only, at the rate of 2 for $1 \mathrm{c}$, prepaid.

Blooming: The Gladiolus surpasses all other flowers for cutting purposes and good keeping qualities. Personally I prefer to bloom Gladioli in the house, cutting the spikes when the first two or three flowers open. Cut with a sharp knife to avoid bruising the stems. Cut spikes so as not to remove any more of the foliage than is necessary, leaving about four good strong leaves to develop new bulbs for next year. Each morning remove wilted blossoms, cut off a little of the stems, with a long slanting stroke (not square across), rinse and give fresh water. Keep inside of vases, etc., clean. The flowers will last longer if these suggestions are followed. Placing the cut Gladioli in a cool cellar overnight refreshes and improves them.

After Blooming Season Is Over: Shallow cultivation should be continued in order to develop good strong bulbs for next season. Less watering is needed from this time on and especially as the harvesting time approaches. As soon as the foliage begins to turn a yellowishgreen, usually four to six weeks after blooming, the bulbs are then ready for-

Digging and Storing: If the greatest increase of cormlets is desired, bulbs may be left in the ground longer than above mentioned though they should be dug before hard freezing. When digging, cut off the tops close to the bulbs. Dry well in the air and sunshine. Cure thoroughly indoors for a few weeks, then store in a cool, dry cellar. A covering of sand while in storage (after bulbs are well cured) is a protection against frost or dampness. Keep as near forty degrees as possible. Dampness in storage tends to develop disease.

It is best not to pile bulbs to a depth of more than four inches while in storage. Florist's flats are most suitable for this purpose. Such a crate may be made with sides and ends of four-inch boards, using plastering lath, closely laid, for bottoms. Make crates two feet square or $24 \times 30$ in., as may be best suited to your purpose.

Cleaning Bulbs: Bulbs should be (Continued on Page 92) 


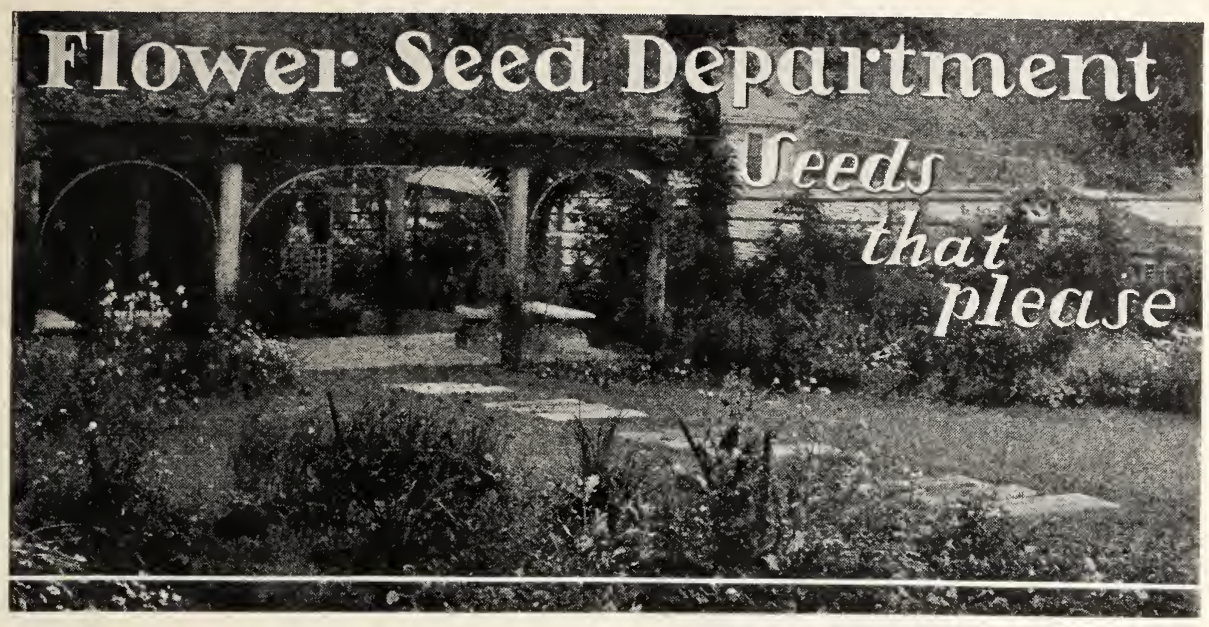

THE growing of beautiful flowers is not difficult-the whole secret to success is primarily good seed and proper care.

The Flower Seed Department is intended to be helpful to my customers and friends who are interested in flower gardening. In the following pages I have assembled a fine list of flowers from which I think you can easily select those kinds in which you are most interested. There are the standard old favorites and those indicated by a ( $*$ ) are the newer novelties.

Flower seeds are inexpensive and yet from the small cost can be had the greatest enjoyment. When the Spring returns, when the smell of bon-fires is in the air, we all long for something to do out-ofdoors. This is garden time, the grandest and most enjoyable time of all the year. Those who have had gardens before can appreciate the happy, healthful hours they have spent among their flowers. The greatest satisfaction of all is to know that the flowers you pluck are from the seeds you planted. Don't miss the fun of watching your flowers and caring for them. Gene Stratton Porter once said, "There are few joys in the world equal to the joy of a garden, and a garden sets off a home as an appropriate frame does a picture."

Many of the disappointments with flower seeds are due to lack of proper conditions, and while it would be impossible, in the small space available in this catalog, to give definite instructions I believe if you will follow the general directions given here that you will have good results.

Most flowering plants will live in almost any soil, but to give them a fair chance to develop, some care should be taken to make the ground suited for their needs. The soil best adapted for flowering plants generally is a light, friable loam, containing a sufficient amount of sand to render it porous. Many flowers are better if produced on plants of vigorous growth, hence a portion of the garden should be prepared by deep digging, thorough pulverization and liberal enriching with large quantities of well-rotted manure. Since some other varieties produce the largest and finest colored flowers when grown on rather light, poor soil, a portion of the garden should not be enriched.

Cultural directions are given on the packets, and I urge purchasers to study them carefully. While some seeds need special treatment, this general rule will apply to all. Make the surface of the soil as fine, smooth and level as possible, and do not plant when the ground is wet.

The vitality of all the seeds is tested before sending them out, and only those of strong germination are sold. Most failures of seed are due to causes beyond my control, such as unfavorable weather and soil conditions; sowing too deep or too shallow; insects of different descriptions destroying the plants as soon as or before they appear; all of which render it impossible for me to guarantee success. While I exercise the greatest care to have all seeds pure and reliable, in common with other seedsmen, I give no warranty, expressed or implied, and will not be responsible in any way for the crop. If the purchaser does not accept the seeds on these terms and conditions, they must be returned at once. 
${ }^{*}$ A-Annual ${ }^{*} \mathrm{P}$-Perennial ${ }^{*} \mathrm{~B}$-Biennial African Golden Daisy ( $D$ i photheca) *A. 12 to 15 inches $\mathrm{H}$. annual from Africa, invaluable for bedding in sunny situations.

Aurantiaca. Flowers glossy, rich orange gold with dark center, surrounded by black zone. This is the parent variety..................... 10kt. Ageratum (Floss Flower) *A. One of the best bedding plants, being literally a sheet of bloom from early summer till frost. Unlike many bedding plants, their flowers are not liable to be spoiled by rain, nor do the colors fade out. Easily raised from seed, which is usually started in a hotbed or window and transferred to the open ground in May. Can also be sown outdoors in May.

$\star$ Blue Cap. A new very dwarf and compact variety, blooming freely with larger flowers than any of the older dwarf sorts, splendid for edging.............Pkt. 25c

Little Blue Star. A splendid plant of easy culture. May be started in hotbeds in March or seeded outside when the ground is warm. Plants grow about five inches in height. Bright blue....Pkt. 15c Alyssum (Little Gem)*A. Pretty Alyssum little plant for beds, vases, baskets, edgings or rock work. Very sweet scented. Little Gem is of dwarf, compact habit, growing but 4 inches high. The plants begin to bloom when quite small and are a solid mass of white from Spring to late Autumn.

Pkt. 10c

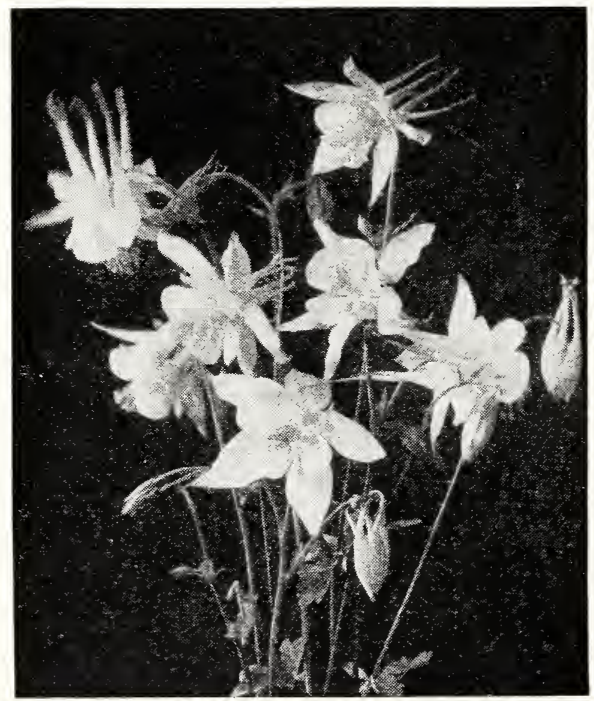

AQUILEGIA or Columbine
Antirrhinum (Snapdragon.) * A. It is not to be wondered that the Snapdragons have become so very popular during the last few years for, whether used for cutting or for show in the garden, they are one of the most valuable flowers which can be grown from seed. Seed sown out-doors the first week in May usually comes into bloom early in July, remaining in full flower until November. For earlier blooming they may be started indoors or in a frame in March, transplanting them to the open when the weather is suitable.

\section{GIANT FLOWERING}

Apple Blossom - Pink and primrose color .....................Pkt. 15c

Defiance-Bright scarlet in color Pkt. 15c Golden Queen - A very beautiful deep yellow ..................Pkt. 15c

Purple King .................... 15c

Rose Queen-Rose color.........Pkt. 15c

Ruby-Dark red ................ 15k

Snowflake-White .............Pkt. 15c

Venus - Pink on white ground, white throat superb .................15t. 15c Giant Flowered Mixture..........Pkt. 15c Aquilegia (Columbine.)*P. No seed is more easily handled than the Columbine. Seed may be sown in the open ground early in Spring, and will, in some cases, bloom the same season; or they may be planted in August or September, and make vigorous plants, which will bloom abundantly during late Spring and early Summer. Columbines should be planted wherever their presence will help to lighten up a too stiff and formal planting, for no other plant has so airy a grace and is more generous of its blooms, or more effectively adapted for cut flowers.

Double. A fine assortment of mixed colors; different shades of blue, rose, yellow, purple and white...........Pkt. 10c * Copper Queen (Coerulea Cuprea). A new and distinct color of this beautiful flower. The petals are broad and of a decided copper-red with long spurs of a darker hue, and the corolla is a straw color changing to white which produces a charming effect ................. $k$ kt. 35c $\star$ Crimson Star (Long Spurred Hybrid). This is a distinct color in the Long Spurred Aquilegia, a brilliant dark crimson, splendid for mass effect, one of the best of the season's novelties.....Pkt. 25c

Long Spurred Hybrid Mixture. This is an extra fine mixture of an improved strain of these beautiful Long Spurred Aquilegia................... 15kt. 15c $\star$ Red Riding Hood. A charming variety of double Aquilegia. Umbrella like, color old rose. Calyx is spread out above the 
pure white double corolla of these dainty blooms; a very uncommon and effective color combination.............. Pkt. 50c Asters *A. These flowers will thrive Asters in any good soil, prepared in the same way as you would for a crop of vegetables, but it is well to remember that any extra care taken in the preparation of the soil is repaid by finer plants, larger blooms, with longer stems and more profuse flowering.

They should have an open, sunny position, and prefer a good, heavy, loamy soil, enriched with a liberal quantity of bonemeal; and the addition of wood ashes or air slacked lime, and should not be planted on the same ground year after year.

California Giant. A combination of the large ostrich feathered type of flower with the long, branching stems of the beauty type.

Dark Purple ..............Pkt. 15c

Light Blue ................... 15c

Rose .............................. 15c

White ................... 15k

Mixture .................... 15c

Giant Hohenzollern. A late branching Aster of the comet type. Immense flowers with beautifully broad, wavy petals. Fine for cut flowers. Mixture of all colors...................Pkt. 15c

Heart of France. A beautiful deep-red aster, splendid for cutting.......Pkt. 15c

Kunderd's Premier Mixture. This Mixture is made up especially for those who wish to grow an assortment of Asters. It includes the cream of the best varieties: Early, Midseason and Late Flowering, as well as the novelties offered this year...................... 35kt. $\star$ Hercules Bright Blue. A distinct color in this Giant Ostrich Plume type. Flowers 5 inches across with beautifully curled petals. Strong stiff stems contribute to making this fine mid-season Aster a most valuable one................Pkt. 40c $\star$ Hercules Shell Pink. This new shade of Pink, a very delicate tint, possesses all the merits of the Blue and is sure to become as popular................... Pkt. 40c $\star$ Sunshine. This is an improved Anemone Flowered Aster of great beauty; all the flowers have a cushion-like center of tiny quills of a contrasting color which adds to their decorative value-there are many shades of pink and blue, also white in the seed we offer which may be depended upon to supply the most attractive asters for cutting; their delicate beauty is hard to describe, the flowers are borne on long stiff stems and last a long time in water............... Pkt. 25c Balsam (Lady Slipper or Touch-MeNot.)*A. A tender annual,

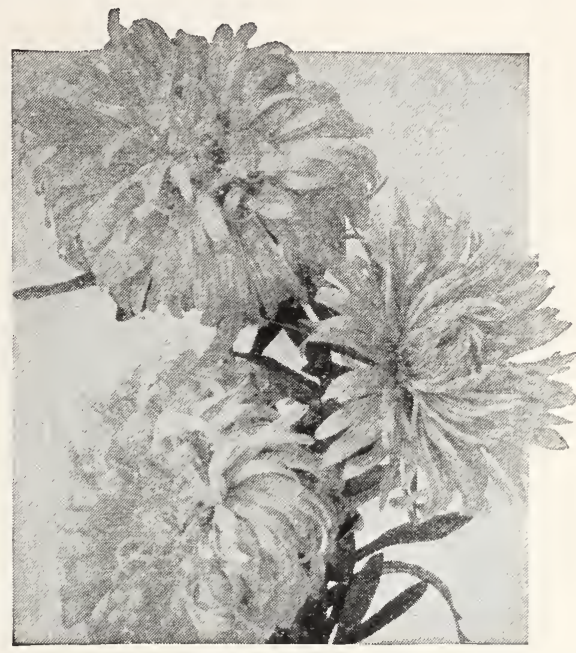

ASTER

with brittle stems and foliage. Grows about 12 inches high. Plants are profusely covered with large double waxlike flowers of brilliant colors, some selfcolored, others blotched, spotted, and striped in a wonderful manner. Desirable for garden or pot culture. Mixed varieties.....................Pkt. 10c $\star$ New Bush Flowered Type. This beautiful new Balsam produces flowers at the tips of the spikes, differing from other types which produce their blooms along the stems. A very beautiful production.

Pkt. 20c

\section{Blue Lace Flower (Didiscus Coeruleus.)}

*A. This pretty and interesting annual blooms most profusely from July till November; their exquisite pale lavender blossoms are excellent for cutting; plants grow about 18 inches high. Sow where plants are to bloom............Pkt. 10c Calendula (Pot Marigold.)*A. This Shakespeare's time; one of the best and showiest free-flowering, hardy annuals. Grows in any good soil and produces a fine effect in beds of mixed borders, particularly bright in late fall.

$\star$ Campfire. This is a distinct and much improved variety. The very large double flowers are a brilliant orange with a scarlet sheen which enhances the beauty and general character of the flower and are borne on extra-long stems.......Pkt. 25c

Lemon Queen, a rich lemon-yellow. .10c

Orange King, glowing orange.....10 c $\star$ Radio. Medium size orange flower with quilled or comet petals, curled and twisted, borne on medium length stems. Recent introduction from Europe. Pkt. 25c

Mixture ................. Pkt. 10c 
Calliopsis *A. Showy, free-flowering, of the easiest culture, doing well in any sunny position, blooming all summer, and excellent for cutting and massing. It is best to sow them where they are to bloom. By keeping the old flowers cut off, the flowering season can be lengthened until late Autumn. Finest mixed............Pkt. 10c

Campanula (Canterbury Bell.)*B. Beautiful bell shaped flowers. Wonderfully showy in beds or borders, and fine for cutting. Colors of white, rose, blue, and purple mixed.

Pkt. 10c

Candytuft *A. Showy, branching plants twelve to fifteen inches high and bearing in profusion terminal clusters of beautiful, single cruciform flowers in a wide range of colors. Considered indispensable for cutting and very effective in beds, masses or rockeries. Mixture.............Pkt. 10c Hyacinth-Flowered - White, $1 \mathrm{ft}$. Fine for cutting................ Pkt. 10c Carnations Marguerite Mixed.*A. Carnations This fine mixture contains all of the various colors of the Marguerite variety - pink, white, and scarlet. These very popular favorites are valuable for culture in the open ground in summer and for pot culture in winter. Seeds sown in the spring will, by August, produce plants that will be full of bloom, until frost takes them; or they may be cut back, potted, and carried over winter in a cool room..............Pkt. 10c

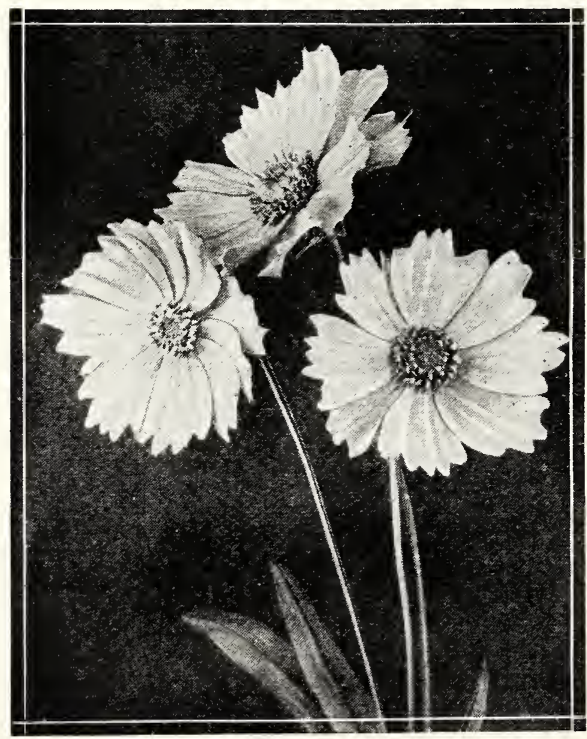

COREOPSIS
Centaureas (Cyanus, Corn-flower, Bachelor's Button.)*A. Two feet. Very attractive flowers of easiest culture; one of the most graceful of all. Sow early in the spring in the beds where they are to bloom. Thrives well in poor soil. Mixed colors....Pkt. 10c

Imperialis (Sweet Sultans.)*A. 1 to 2 $\mathrm{ft}$. These are undoubtedly the finest of all Centaureas for cut flower purposes. The sweet-scented, artistic shaped flowers are borne on long, strong stems, and when cut will stand for several days in good condition. It is best to sow seed very early in the spring. Mixed colors.

Pkt. 10c

Chrysanthemums ${ }_{\text {hardy an- }}^{*}$ These nuals are summer-flowering border plants (growing about $2 \mathrm{ft}$. high), bearing in profusion large daisy-like flowers on good stems, and quite distinct from the hardy perennial and autumn flowering varieties.

Annual Single Mixed (Painted Daisies.) Many colors...................Pkt. 10c

Evening Star (Single.) A splendid variety for cutting, flowers 3 inches across, of pure golden-yellow; in general appearance resembles the Yellow Paris Daisy.

Pkt. 10c

Northern Star. Pure white, with canary-yellow zone around a dark brown eye.......................Pkt. 10c

The Sultan (Single.) Crimson maroon.

Pkt. 10c

Coreopsis Lanceolata Grandiflora. finest of large, showy, bright yellow flowers produced in the greatest abundance from June till frost. Easily grown from seed, flowering the first year if sown early..........Pkt. 10c $\star$ Lanceolata Grandiflora Fl. Pl. (New Double Flowering.)*P. Coreopsis Lanceolata has for a long time been a gem in the perennial border. This new double and semi-double form is just as easy to grow and the extra petalage adds a further charm to the flower. Will bloom first season if seed is sown early........Pkt. 15c

$\star$ Cosmos Early Express Bright Pink. *A. A new very early Cosmos, flowering within fifty days from planting. Valuable also on account of its dwarf habit of growth, $2 \frac{1}{2}$ to 3 feet. Blooms freely ..................Pkt. 25c

Early Flowering. From seed started early in frames, and afterwards transplanted into light sandy soil, the plants will be 3 or 4 feet high by August, and will bear bright-colored, daisy-like flowers until frost. Mixed........... Pkt. 10c

Late Double Crested. These are considered one of the best flower novelties 
of recent years. The colors are similar to those of the old type............Pkt. 15c $\star$ New Extra Early Double Flowered. This valuable flower grows to a height of about three feet, forming a perfect bush massed with bloom, bearing beautiful double flowers of good size on long stems. This strain comes about seventy-five per cent double from seed. They bloom in seventy days from planting, so that seed sown the latter part of April will easily be in bloom by the Fourth of July and continue till cut down by frost....Pkt. 25c $\star$ Cynoglossum Me-Not) Amabile $_{\text {(Chinese }}$ Forget*A. A lovely plant 18 to 24 inches tall with flowers of a true Forget-Me-Not blue. It is a hardy annual of recent introduction from China; will thrive in warm weather better than the ordinary Forget-Me-Not. It is ideal for bedding as well as for cut flowers.........Pkt. 10c $\star$ Cynoglossum Pink *A. A new color, same habit of growth as Blue and White, makes a very dainty and pretty cut flower...................... 15kt Delphinium ${ }^{* P}$. Four to six feet. fine flower is coming into favor. It is hardy, grows easily, has a long period of bloom, and gives to the garden one of its stateliest plants. Seed may be sown any time from Spring till Autumn. Sow in fine soil to a depth of the seed, not deeper than $1 / 8$ inch. Firm the soil and moisten thoroughly. Keep shaded and moist, with a free circulation of air at all times. In about 20 days the pointed seed leaves will appear, remove shade and when the true, or round leaves appear, transplant to their permanent places.

$\star$ Blue Bird Strain. The seed of this beautiful Perennial Larkspur is procured from one of the finest and largest collections of Delphiniums in this country. A collection-the result of testing the most famous strains procured from all over the world and selecting the finest. The range of colors vary from the palest shades of blue to the deepest indigo and royal purple with many intermediary pastel tones of mauve, pink, and lavender blendings and combinations difficult to describe. The huge flowers are single, semi-double and double and bear on graceful long stems; the semi-double flowers are the most admired....Pkt. 50c

Gold Medal Hybrids. These magnificent Hybrids produce splendid spikes of very large flowers, single, semi-double, and double. Flower spikes are from three to five feet in length. Colors range from pure white through all tints and shades of blue and lavender.............Pkt. 15c $\star$ The Hollyhock-Watkin Samuel's Eng-

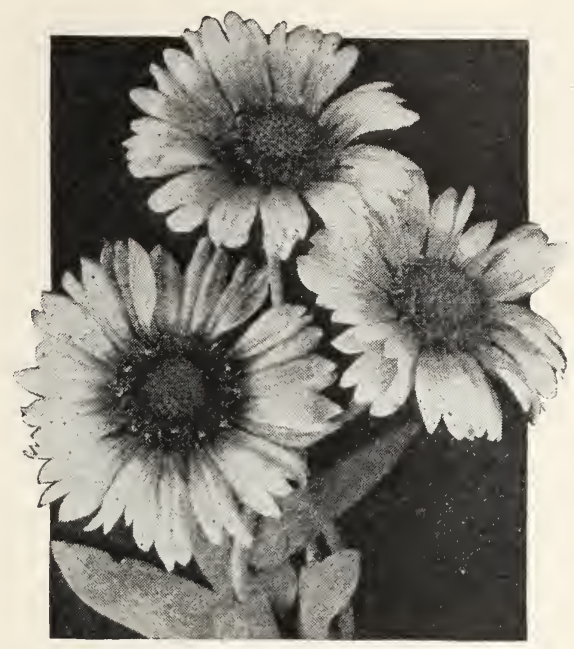

GAILLARDIA

lish Wrexham Strain. Pudor, a Delphinium specialist writes in regard to this fine strain: "This is the last word in English Delphiniums. They are now blooming in $m y$ garden - and so marvelous and huge are they, that they take your breath away."

The Wrexham flowers are enormousthe "bees" immense. Watkin Samuel's stalks are superb; he has striven for church-steeple shaped, tall flower stalks, and he has succeeded...........Pkt. 50c $\star$ Wrexham Coquette, Violet shaded to deep blue. Height, $6 \mathrm{ft} . . . . . .$. Pkt. 50c $\star$ Wrexham Queen Mauve. Charming silvery-mauve. Height, $6 \mathrm{ft}$........Pkt. 50c Dianthus (Pinks) Kunderd's "Brilliant" Mixture of Double and Single Pinks.*A. This splendid mixture contains the cream of the Dianthus family. White and dark crimson selves, also white tipped light purple and shades of red with darker blotchings. A mixture of double and single pinks unsurpassed in variety of brilliant coloring and marking; desirable for cutting.............Pkt. 10c

Plumarius Cyclops. Hardy Dwarf Pink, many beautiful colors with blood red eye, blooms freely all summer, especially suitable for rock gardens............ Pkt. 15c

Plumarius Semperflorens (Florists Perpetual Pinks). Hardy double and single mixed. These beautiful pinks or carnations are magnificent for the home garden. Bloom the second year from seed.

Pkt. 15c $\star$ Sweet Wivelsfield.*B. This is a new hardy annual which resembles a large flowering Sweet William. It is distinct in habit and freedom of growth, its flowers being carried gracefully in loose 
heads, well above the foliage. Reds, pinks and crimsons are the predominating colors. Grows about 12 inches in height. Sown in the open ground in April it will bloom late in the summer, or it can be sown in summer or autumn for flowering early the next spring. Very desirable for rock gardens. Choicest home grown, hand picked seed. Mixed colors......... Pkt. 25c $\star$ Eremurus (Foxtail Lilies.) Grows Eremus 4 to 8 feet tall; very hardy. Very scarce in this country. Colors, yellow, pink and white. Only mixed colors can be offered this year. Pkt. 35c

\section{Eschscholtzia (California Pop-}

si-a. A low growing, very pretty annual with bright colored flowers and feathery foliage blooming freely all summer.

Ballet Girl. A beautiful carmine, shading to creamy white...........Pkt. 10c

Golden West. A clear yellow..Pkt. 10c

Single Mixed ...............Pkt. 10c Four 0'Clock *A. Large and ioned plants of erect, bushy habit, which produce in profusion a succession of brilliantly colored tube shaped flowers, that open about four o'clock in the afternoon, remaining open all night and usually are closed before noon the next day. The flowers are red, white, yellow, or are striped and blotched in shades of these colors. Very desirable for borders, along a wire fence, or as the background of a flower garden, blooming during the late

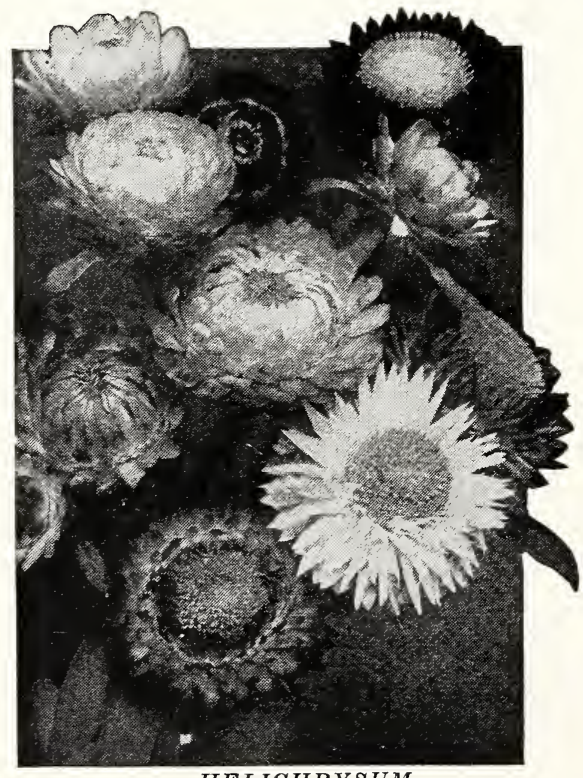

HELICHRYSUM summer and autumn. Finest mixed.

Pkt. 10c, 3 for 25c

Gaillardia *P. Hardy perennial but will bloom first year if seed is planted early. There are no plants which put more life in the perennial border and are content with such simple treatment.

$\star$ Burgundy. In this novelty, the dainty yellow edging has completely disappeared; thus it is the ideal of the all red perennial Gaillardias satisfactorily realized. The shining wine-red marguerites are produced liberally on long stems by the bushy plants $21 / 2 \mathrm{ft}$. high. They flower from June until autumn and if sown in March blooms will appear the same year. 60 to 70 per cent pure red flowers can be counted on. Most effective both in perennial borders and when cut.

Pkt. 35c

$\star$ The Dazzler. By far the largest and most attractive Gaillardia to be had. The flowers are very large of a dark, rich red with a bright orange tip on the end of each petal making it a very attractive flower for house decorations; has long stiff stems and great lasting qualities when cut. A flower of real merit.. Pkt. 15c

Kelway's New Hybrids. Striking combination of orange and scarlet. Blooms until frost. Fine for cutting......Pkt. 25c

Kunderd's Special. New strain of Giant Flowered Gaillardias. Imported from Germany. Choice new colors. Extra fine. Perennial. ...................Pkt. 15c

Annual Varieties (Single). Excellent for beds, borders, or for cutting; should be sown where they are to bloom. $11 / 2 \mathrm{ft}$.

Pkt. 10c

$\star$ Gladiolus Seed I am sure a my friends and those interested in the possibilities of new Gladioli will appreciate the fact that I am offering seed from my private planting. While there cannot be any assurance of just what exists in these seeds, the finest Gladiolus the world has ever seen may be produced from them...............200 seeds 50c Gypsophila (Baby's Breath.)*A. Blooms in such profusion as to produce a mistlike effect. Valuable for trimming bouquets...................Pkt. 10c

Panticulata.*P. Pure white. Plants make fine clumps for garden use. Perennial.......................... 10c $\star$ Helianthus (Sunflower) Excelsior Hybrids.*A. This is an exceptionally fine mixture of small flowering Sunflowers with the red shades predominating and many of the flowers have a large red disk on a yellow ground which makes them a very attractive dec-

To Have the Best, Be Sure You Buy Your Bulbs from Kunderd 
orative flower. The average growth is 3 to 4 feet and branching; flowers may be cut with long graceful stems and will last a few days in water-are very suitable for planting among shrubs or in the rear of the flower border.........Pkt. 15c Helichrysum (Straw Flower.) ular of the so-called Everlasting Flowers, to dry for winter decorations. For this purpose the flowers should be gathered when on the point of expanding. Sow early in spring; thin to one foot apart each way. Hardy annual; 2 to $2 \frac{1}{2} \mathrm{ft}$. high.

$\star$ Monstrosum Silvery Pink. A pleasing new shade of the popular flower. Color a silvery cameo pink. The blooms are two inches in diameter and make a striking appearance either in the garden or when cut........................ Pkt. 15c

Mixture. Large, full, double daisylike flower heads with prominent centers and stiff, overlapping scales, produced in various shades of bright-yellow and scarlet, on stems of good length. Finest mixed colors...................... 10k $\star$ Hibiscus (Mallow Marvels.)*P. Herbaceous Perennial, red flowering strain, $5 \mathrm{ft}$. Blooms August to October. Showy ornamental plants for mixed beds or shrubbery borders or specimens. Blooms first year from seed if sown early. Sow seed $1 / 2$-inch deep, in May, and transplant to 2-3 ft. apart the second spring. The seed I am offering is of exceptional quality. It is a strain which I have been developing from the original "Meehan's" introductions. I have been selecting these and breeding them up through a number of generations and I think they are much better than any I have ever seen. The many visitors who come to my place and see these Hibiscus marvel at their great beauty. The flowers are very large and of a rich dark red color......................... 25kt. Hollyhock ${ }_{\text {Hollyhocks make a fine }}^{* \text { B. Six to eight }}$ row in a garden, a fine background next to a building, or high wall or fence. The double varieties are the most desirable, but the newer, semi-double, fringed types are also very popular. Seeds of the double varieties sown before mid-summer will insure fine plants the following season. Sow the seed one-half inch deep. Hollyhocks need a rich, well cultivated soil. If troubled with rust, spray freely with Bordeaux Mixture. May be used for cut flowers if the ends are charred over a flame as soon as cut. Choice double mixed.

Pkt. 10c

Kochia (Summer Cypress and often called Mexican Firebush.)

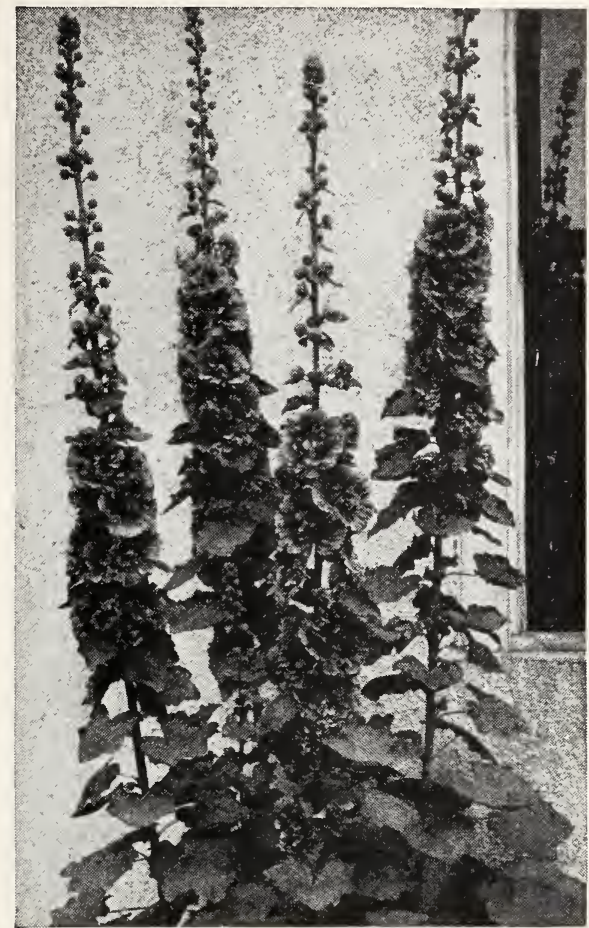

HOLLYHOCK

*A. Kō'-ki-a. Two or three feet. Makes a pyramidal-shaped cypress-like bush with feathery, light green foliage, deepening until it becomes a lovely crimson hue about September. Childsii. Excellent for hedges along garden walks. .Pkt. 10c Kunderd's Cut-Flower Mixture. mixture of seeds of hardy a special blended to give a continuous succession of beautiful cut-flowers from early summer until late fall. Cut-flowers are much needed for decorative purposes in the home and this mixture will supply different forms and new colors daily during the season. The seed may be sown in the flower garden or better, in rows where the plants can be more easily cultivated and the frequent cutting will not be so noticeable. The more you cut the more you may have to cut if no seed pods are allowed to form. Do not sow the seed too thickly, the plants should average $10 \mathrm{in}$. to $12 \mathrm{in}$. apart, the seedings should be thinned out and may be transplanted to other parts of the garden..................... 15 c Larkspur *A. 18 to 30 in. These Hyacinth-flowered with their long narrow, spikes as well as those of branching 
or candelabra habit. Sow seed 1/4-inch deep as early in spring as possible where they are to bloom. Thin out plants to 12 inches apart. Plant little groups in the garden, making attractive spots of color all through the summer and fall. Fine for cutting.

Branching. Mixed...........Pkt. 10c

New Giant Hyacinth Flowered. A superb class. Mixed............Pkt. 15c

Tall Rocket. Long showy spikes.

Pkt. 10c

$\star$ Empress Rose. An introduction of unusual merit, the large double flowers are a rich rose color and are borne profusely on long straight stems that are excellent for cutting and charming in the open bud. ........................ 15c $\star$ Giant Imperial Blue Spire. Intense deep oxford blue, same branching habit of growth as the popular Exquisite Pink.

Pkt. 15c

$\star$ Giant Imperial Exquisite Pink. A soft pink shaded salmon. One of the newer and very popular branching type Larkspur...................... 15kt. $\star$ Giant Imperial Gloria. A 1932 introduction. A new color in this popular type of Larkspur. Deep rose, darker than La France. Sure to become a favorite as a cut flower because of its desirable color and length of stem............Pkt. 25c $\star$ Giant Imperial Lilac Spire. Beautiful

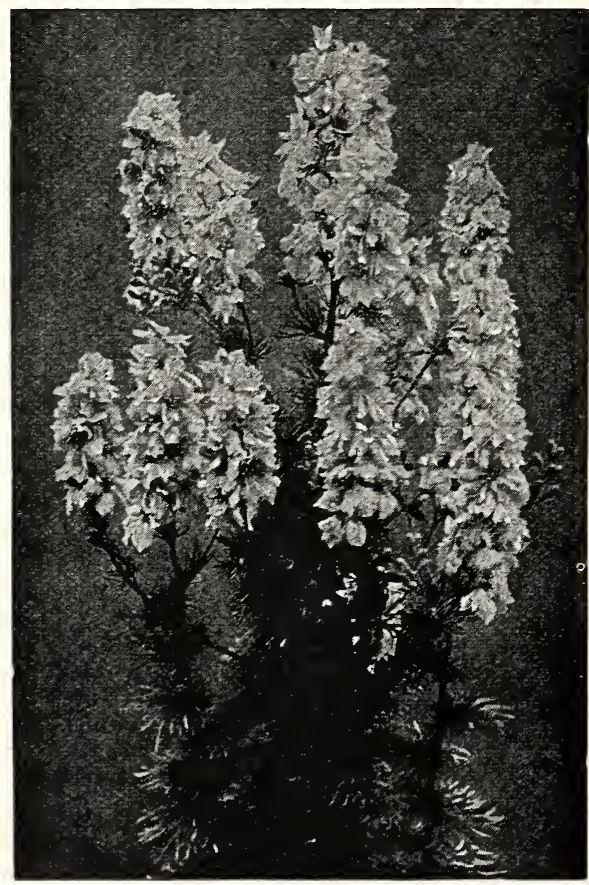

ANNUAL LARKSPUR-“LA FRANCE" blue color of the same substance and size as the Giant Imperial Blue.......Pkt. 15c $\star$ Giant Imperial White Spire. A new pure white double Larkspur, with long showy spike, splendid for cut flowers.

Pkt. 15c

$\star$ La France. Not only a new color in Annual Larkspurs but of much better habit than the older varieties. Color is a very pleasing salmon-pink and the large well formed double flowers are well placed on long stems making it one of the most desirable cut flowers.............Pkt. 15c $\star$ Los Angeles. Rich salmon ground overlaid with a brilliant and pleasing rose. Type of growth similar to La France but foliage is much darker green, making the large double flowers stand out more prominently. Both Los Angeles and La France are particularly good under artificial light. ..................... 25k Liatris Kansas Gayfeather. *P. Flowblossom are a rosy purple. The downward instead of from the lower part of the spike upward as in most of the spike flowers. This is a very beautiful perennial. Blooms on tall spikes 3 feet or more in height. Beautiful either as a cut flower or for landscape..........Pkt. 15c $\star$ Lupinus (Lupine.)*P. English Hyfamous strain. Tall, stately blooms, very fragrant. Mixed colors. Valuable for borders, beds or cuttings; prefers a little shade...................... 25k Marigold *A. No flower-garden Marigold seems complete without this fine, old-fashioned garden plant with its brilliant display of yellow and orange, both tall and dwarf sorts, and with finely cut, bright-green foliage. The African varieties are tall, usually one and one-half to three feet, and are well adapted for large beds, backgrounds of mixed borders, while the French are more dwarf and are often used for borders and pot culture as well as bedding.

El Dorado. Orange, yellow....Pkt. 10c

Dwarf French, Finest Mixed..Pkt. 10c Lemon Queen. Light yellow...Pkt. 10c Orange Prince. Fine orange...Pkt. 10c Tall, Double African Mixed.....Pkt. 10c

Tall African All Double. New mammoth flowering Marigold, an improved Orange Prince, blooming practically 100 per cent double................

Tagetus Signata Pumila. Is an attractive, shrubby little plant growing about 10 inches high with fern-like foliage and small clean-cut golden yellow flowers. For low-growing borders try combining with Ageratum, Mignonette, Bachelor's Buttons or any other loose-growing low plant of a color that combines well with yellow. Avoid planting closely, which 
gives an appearance of too great solidity to the border............. Pkt. 10c

Marigolds deserve a place in every garden.

\section{Mignonette}

*A. A well-known hardy annual, producing dense coneshaped flower spikes, made up of thickly set florets of modest colors. It is often used for cutting to combine in bouquets with other pretentious flowers lacking its delicate and pleasing fragrance. Seed is usually sown outdoors after danger of frost is over and if sown at intervals in spring and early summer a succession of bloom, under favorable conditions, is assured till late frost. Well pulverized soil, preferably light, sandy loam, should be used and the seed covered one-fourth inch deep.................. 10 c, 3 for 25 c Nasturtium Kunderd's Premier Nasturtim Mixture of Tall Nasturtiums. *A. A gorgeous mixture. It contains all the new Giant flowering plants. A diversity of rich colors and new and striking combinations is found in this mixture. A row in full bloom is truly gorgeous, containing every shade and tint of yellow, rose, scarlet, orange, carmine, violet, purple, lemon, bronze, maroon, ruby, cream and pink, both in solid colors and mottled and striped in many ways............Pkt. 10c, 3 for 25 c

Kunderd's Premier Mixture of Dwarf or Tom Thumb Nasturtiums. Will give a larger variety of colors in even proportions than any other Nasturtium mixture, for it is put up from named sorts, and also contains a large share of the Lilliput Nasturtium and the dwarf Chameleon, which have the richest and most varied combination of colors ever produced............... ^New Double Sweet Scented - Golden Gleam. Double Nasturtiums are not new, but up to this time have been propagated only by cuttings, and it has been generally believed they would not reproduce themselves from seed. It gives me great pleasure to offer this unique novelty in Nasturtiums.

Plant forms a vigorous, large bush which throws out short runners, averaging eighteen inches. The flowers commence to come as soon as the plant nears complete development, and at the time it is in full bloom the entire plant, including the runners, is a blaze of color. The large, golden yellow flowers average $2 \frac{1}{2}$ to 3 inches across. They are borne on erect, stiff stems 6 inches in length. Consequently the flowers stand well above the foliage, an arrangement which adds immeasurably to the showy appearance of the plant.

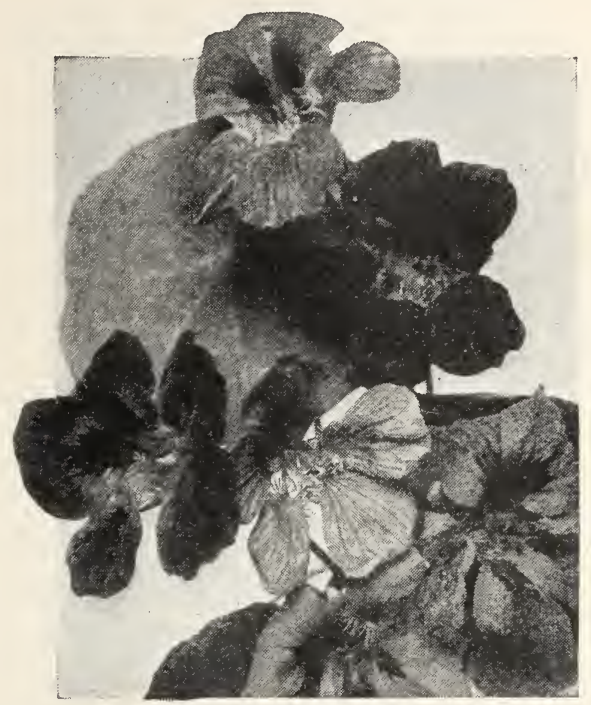

NASTURTIUM

When well grown these flowers have the appearance of a fully double flower, and are most attractive. An ordinary sized bouquet, when allowed to remain in a room for a short period of time will fill the room with fragrance.........Pkt. 30c $\star$ Nicotiana Crimson Bedder.*A *icotiana The Nicotinia Affinis, though valued as a fine decorative plant for groups and the rear ranks of borders, has hitherto not been found suitable for general bedding purposes. This novelty is a distinct break in this direetion, being of dwarf and pyramidal habit, not exceeding about 15 inches in height. The flowers are of a rich deep crimson color and very freely produced, making a most striking effect when seen in the mass; "Crimson Bedder" comes fairly true from seed........... Pkt. 35c

Pansies *A. Seed sown in shallow preferably, in a cold frame where one is available, will produce. fine flowers in summer and all through the fall. If the seed is sown in spring, outdoors, in a partially shaded location, the seedlings will bloom in autumn. The plants, if given a slight protection of leaves, usually come through the winter unharmed. Take care of the weakest looking seedlings, as they usually give the finest flowers.

Masterpiece. Petals curled and twisted. Very large flowers more or less blotched and in combinations of colors. The nearest approach to a double pansy... Pkt. 15c

Bedding Mixture. A pretty strain. The flowers are smaller than those grown 
from our other mixtures but there are more of them...............Pkt. 10c

Giant Mixture. Made up from and including seeds of all the Giant Flowering Pansies, and several other sorts not otherwise obtainable than in this mixture.................. 15ct. 2 for 25c $\star$ Swiss Giant Mixture. This wonderful new class is entirely different to any other Pansy. The beauty, brilliancy and richness of the entirely new color tones is most striking. The perfectly round flowers are held on strong stems well above the unusually vigorous plants....Pkt. 35c Petunia *A. No bedding plants Petunia make a more pleasing display than petunias. The distinct colors and markings make a brilliant show. The plants make a strong growth and bloom profusely until after hard frosts.

$\star$ Marshall's Violet Queen. Exquisite single Petunia. Grows from 12 to 18 inches in height. Color, dark violet without a trace of magenta. Surpasses any of its type for border and bedding. Plants are robust and continuous bloomers with flowers averaging from two and one-half to three inches across from early summer until late fall................... 25k $\star$ New Dwarf Fringed Rosy Morn. Bright rose. This beautiful new Petunia has all

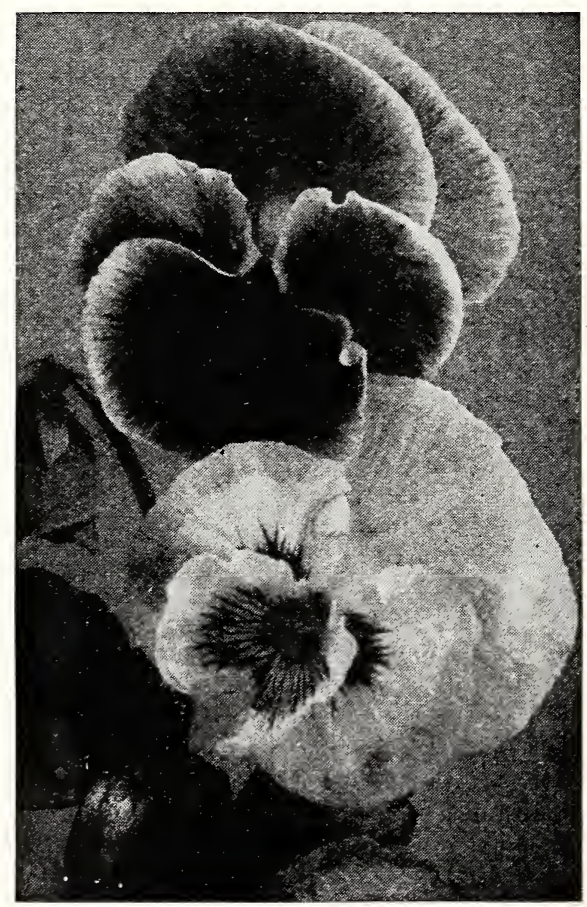

PANSIES the lovely daintiness of the single Rosy Morn with the added attraction of the delicately fringed petals.........Pkt. 25c $\star$ New Fringed Petunia, Setting Sun. Comes true from seed, forms compact bush 12 inches high covered with beautifully fringed blossoms of brilliant rose pink, measuring 3 inches across. Fine for borders.................... Pkt. 50c

Rosy Morn. The favorite window-box petunia, also fine for bedding. Delicate pink with white throat...........Pkt. 10c $\star$ Ruffled Giant. Flowers of extraordinary size and substance, and distinguished from the large flowering fringed section by deep fluting, giving the appearance as if artificially ruffled. Pkt. 25c

Single. A desirable flower for bedding or for porch or window-boxes. The seed is very fine and needs only a slight covering. Plant in a warm, open location. I am offering a mixture of the best large flowering varieties in many beautiful colors.

\section{BALCONY PETUNIAS}

Pkt. 10c

Balcony Petunias*A. A very beautiful kind of Petunia. It grows more erect than the ordinary variety and the flowers are large and fine.

Balcony Blue. A rich, velvety, indigo blue ....................2kt. 20c

Balcony Crimson ............... 15k

Balcony Queen. A charming variety. Violet and white..............Pkt. 20c

Balcony Rose. Flowers of brilliant rose-pink .................Pkt. 15c $\star$ Balcony Star of California. Unsurpassed for window and porch boxes, blossoms freely, flowers very showy deep violet with crimson tinge and starred with five pure white blotches, long trailing branches .................... Pkt. 25c

Balcony White. Pure white form of this type ................. Pkt. 15c

Balcony Mixed .............. 15kt. Phlox *A. The annual Phloxes are Phlox dazzling in effect, particularly so when sown in masses or ribbon beds of contrasting colors. Few flowers are so easy to grow from seed, so pretty and compact in habit, so quick to bloom, or give such a brilliant display of color. Finest mixed colors..............Pkt. 10c Poppy *A. Poppies should be sown sible where they are to remain as posdo not stand transplanting. Mix the seed with dry sand and sow very thinly. If they come up too thickly they must be thinned out to stand five to six inches or more apart if you wish best results.

Double-Peony Flowering, ShrimpPink. A bed of these tall, stately poppies should have a place in every garden. The flowers are extremely double and under 
favorable conditions as large as to resemble beautiful pink peonies...Pkt. 10c

Double Mixed.............. Pkt. 10c

Iceland Poppies (Papaver Nudicaule.) *P. While these are hardy perennials, they flower the first year from seed, blooming almost as early as the annual sorts. They are of graceful, neat habit, with bright green, fern-like foliage, formed in tufts, from which issue slender stalks about 12 inches high, bearing their brilliant flowers in endless profusion; most useful for cutting, for which purpose pick when in bud. They remain evergreen throughout the winter.

Mixed Iceland Poppies.........Pkt. 10c $\star$ Iceland El Monte.*A. A deep tangerine orange of enormous size. A hybrid from Australia which comes true from seed in six months. Fine for decorations on account of its brilliant color........Pkt. 25c

Shirley Poppies.*A. These are single and occasionally semi-double, and range in color from the purest white through the delicate shades of pale pink, rose and carmine to the deepest crimson and bloodred, while many are daintily edged and striped. In fact, so varied are they that scarcely any two flowers are exactly alike ...................... 10 c

Single Poppies. Mixed colors. . Pkt. 10c Poppy Oriental (Papaver Orientale.) *P. From the middle of May until the end of June there is probably no flower in the garden that gives more brilliance and beauty than the Oriental Poppy. These Hardy Perennials may be easily grown from seed and are becoming more popular each year. The seed that I am offering is select seed from the gardens of Dr. J. H. Neeley who is recognized as an authority on Oriental Poppies and whose collection contains all of the best varieties among which are the following: Beauty of Livermore, Trilby, Proserpine, Wurtembergia, Mahoney, Mrs. Perry, Perry's White, Rembrandt and Lulu A. Neeley, which is his own production and is considered the equal if not superior to any that has ever been produced.

It will be understood that Poppy seed will not produce true varieties, nor can we expect them all to come true to color. Seed selected from the dark reds may be expected to produce a mixture of seedlings in which these colors will predominate. Seed selected from the white and pink varieties may be expected to produce a preponderance of those colors. While the mixed colors will contain a mixture in which the red and orange colors will predominate but may also have some of the bronze or mahogany colors, along with the whites and pinks.

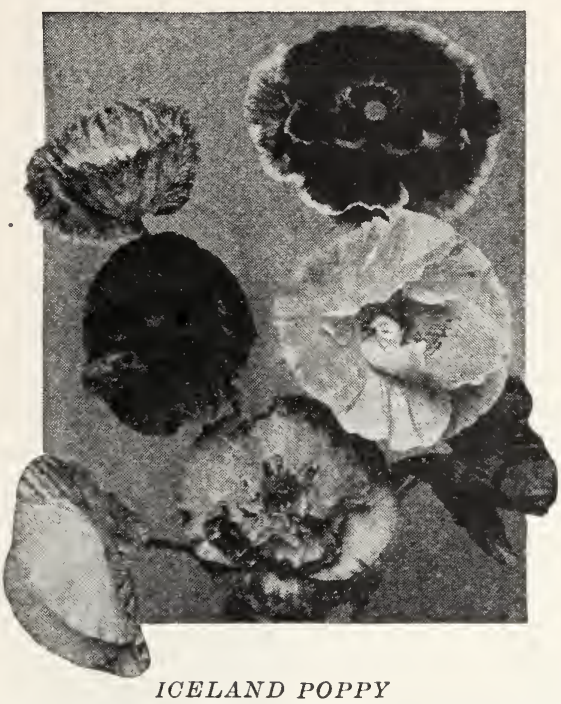

Seed should be sown during the spring or early summer months to produce plants that will bloom the following summer. Cultural directions printed on seed packets.

Select seed from the above named choice varieties.

$\begin{array}{rrc} & \text { Per } & 2 \\ \text { Pkt. } & \text { Pkts. } \\ \text { Dark or Blood Red Varieties 25c } & 40 \mathrm{c} \\ \text { Pink and White Varieties...25c } & 40 \mathrm{c} \\ \text { Mixture of all colors....... 15c } & 25 \mathrm{c} \\ \text { Portulaca (Sun Plant or } & \text { Rose } \\ \text { Moss.)*A. Por-tu-lak'-a. }\end{array}$
One of our finest hardy annual plants, of easy culture, thriving best in a rather rich, light loam or sandy soil, and luxuriating in an exposed sunny location; the flowers are of the richest colors, and produced throughout the summer in great profusion; fine for massing in beds, edgings or rockeries. There always appear single flowered plants among the best of double flowered seed. These should be weeded out as they show bloom.

Finest double mixed..........Pkt. 10c Single Mixed-All colors.......Pkt. 10c Pyrethrum *P. Showy, hardy pefeet in height, with most brilliant and lasting flowers, sometimes called painted daisies; luxuriates in rich sandy soil and plenty of water, especially when in bud.

Hybridum. Double. Aster-like flowers, from pure white to crimson. Mixed.

Pkt. 20c

Salpiglossis *A. Sal-pi-glos'is. Very showy bedding or border plants with richly colored, fun-

\section{Lowest Price Levels of a Low Price Year}


nel-shaped flowers which are borne on long, graceful stems. The flowers of purple, scarlet, crimson, yellow, buff, blue or almost black are beautifully veined or penciled. and are excellent for cut flowers. They are easily grown and are most desirable for beds or borders. Mixed.

Pkt. 10c

Salvia (Flowering Sage.)*A. A Salvia hedge or bed of Salvia is a blaze of color during late summer and fall. They are used to good effect for bordering Canna beds, also for hedges along walks or lot dividing lines. Seed should be started either indoors or in a hotbed; sow about $1 / 4$ in. deep; do not sow in open ground until soil has become well warmed. Transplant from 12 to 18 inches apart; all are treated as annuals.

$\star$ Salvia "Wonder." A new kind, produces flowers so abundantly that the foliage is almost hidden, giving the beds the appearance of a brilliant red carpet. Pkt. 25c Scabiosa *A. Ska-bi-os'a. Twelve Scabiosa to eighteen. inches. This is an old favorite, and of late years has been greatly improved. The flowers are borne on long, wiry stems, in many beautiful colors. An exceptional garden plant and indispensable for cutting. Sow outdoors in May. Keep the seed-pods clipped and the plants will bloom much longer.

Azure Fairy. Blue........... Pkt. 10c $\star$ Giant Loveliness. A new color in annual Scabiosa, soft delicate Salmon Rose. Unsurpassed as a cut flower on account

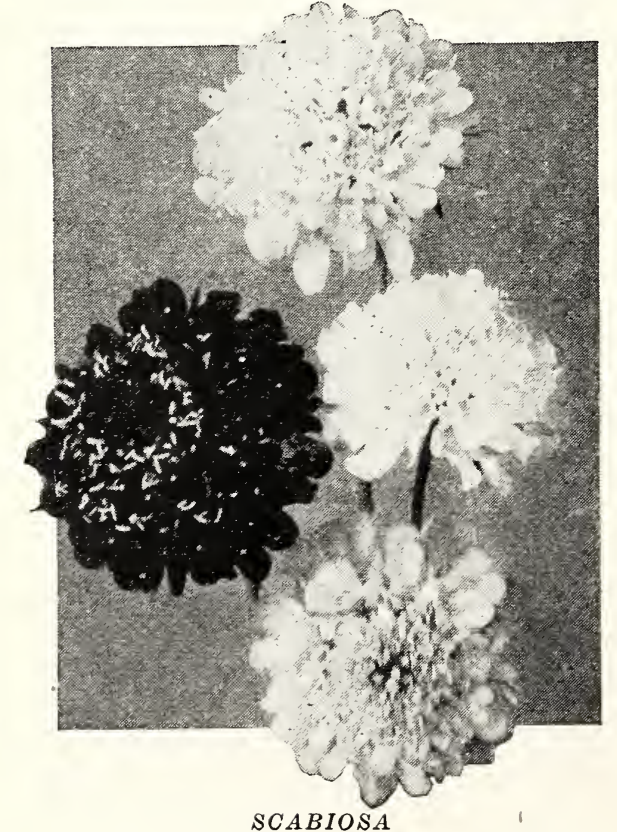

of its attractive color, delightful fragrance and long stems..........Pkt. 25c

Peach Blossom. New pink......Pkt. 15c

Shasta. New white............. 15kt.

Annual-Mixed. Double cone-shaped flowers in many rich colors borne on long stems. Very desirable for beds or for cutting. All colors mixed.........Pkt. 10c Shasta Daisy (Alaska.)*P.Gracepure-white flowers with yellow centers; last a long time. Extra fine cut flowers.

\section{Snapdragons - See}

Stocks ${ }^{*}$ A. Giant Perfection or Cut Stocks and Come Again. An improved strain of this old sweet-scented garden favorite. Flowers are more double and much larger than the ordinary stock. They throw out numerous side branches, all bearing double, fragrant flowers. Excellent for pots or for cutting. My mixture contains shades of blue, scarlet, pink and white..........Pkt. 10c Straw Flowers - See Sweet Peas *A. No garden is too sweet peas. The blooming season usually extends from early summer until very hot, dry weather and no other climber equals it for cutting, either for use in bouquets or for table decorations.

Nothing within recent years can approach in importance the introduction of the "Spencer, Butterfly or Orchid Flowered" sweet peas. They are distinguished from the standard sorts by the enormous flowers with crinkled and wavy petals, and also from the fact that they usually bear four blossoms on a long, stout stem.

America. White striped scarlet.

Austin Frederick. A giant lavender.

Pkt. 10c

Commander Godsall. A very beautiful violet-blue ..................... 10c

Crimson King. A true ox-blood, a pure rich crimson. Very distinct......Pkt. 10c

Dobbie's Cream. A deep primrose.

Pkt. 10c

Hercules. A choice soft rose-pink. Large flowers ................. 10k

King White. No finer white, in every respect, has ever been produced.Pkt.10c

Miss California. One of the newer varieties. A very beautiful orange-salmon.

Pkt. 15c

Warrior. An extremely large flower, maroon, almost black..........Pkt. 10c

Youth. The most fragrant of all sweet peas. With an exquisite pink picotee on the large, pure-white ground.....Pkt. 10c Kunderd's Blue Ribbon Mixture. This 
mixture is a beautiful blend of only the largest and brightest colored Spencers. It includes all the standard Spencers of merit and all the very latest novelties, such as Austin Frederick Improved; Mrs. Tom Jones; Picture; Valentine; Royal Scot; Renown, etc............Pkt. 15c

Kunderd's Premier Mixture of Spencers. Made up from the named varieties in this list and many other choice Spencers including those of recent introduction. Great care has been given in preparing this mixture, so that each packet will contain a balanced proportion of color................Pkt. 10c, 3 for 25 c Sweet William *P. It is one of Sweet Willam the most desirable for display in the garden. The plants are easily grown, hardy and free flowering. They produce a succession of flower clusters, thus affording splendid bloom for several weeks. The florets are handsomely colored and marked and are borne on stiff stems in great profusion, forming dense, round topped heads or clusters, often three to four inches across. The colors are exceedingly varied, ranging from white through many shades of rose, lilac, red, carmine, crimson, and maroon to nearly black, usually two shades to each plant.

Double mixed............... Pkt. 10c

Single Finest Mixed. Very choice single-flowering varieties by many much preferred to the double.........Pkt. 10c

Verbena *A. This well-known annual of low growing, decumbent habit of growth is very desirable for massing in beds on the lawn. It is suitable also for borders and window boxes. Large clusters of showy flowers are borne in succession through a long season until frost. Each truss or cluster is about two or three inches across, and includes a dozen or more single flowers about three-fourths of an inch across, tubular with five spreading lobes. The length of stem and texture of the flowers make them of value for bouquets and table decorations. There is a wide range of colors, shades and stripes usually running from pure white to deep purple.

$\star$ Fireball. A new dwarf Verbena about six inches high, literally covered with brilliant scarlet blooms. Especially valuable for borders..............Pkt. 35c $\star$ Lavender Glory. A new 1932 introduction. True lavender with creamy-white eye, giant size and sweetly fragrant.

New Gigantea Type Lumint. 40c bright-pink, shading to softer shade of salmon ...................... 25kt.

Rosea Stellata. Rose-pink, white eye.

Pkt. 25c

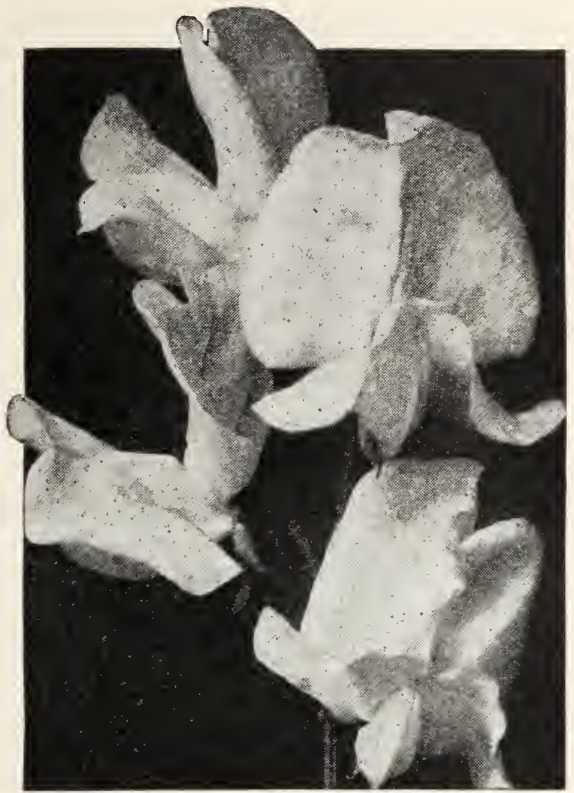

SWEET PEA

Violacea Stellata. Deep violet, white eye ............................. 25c

Gigantea Mixed ............Pkt. 20c $\star$ Viola Cornuta or Tufted Pansies (Also known as Pansy Violets, Johnny-Jump-Ups.)*P. While the flowers of the Tufted Pansies are not so large as the regular type, yet they bloom so freely that they are superior to pansies where effect is wanted. Seed sown in April produces flowering plants by June, and from then on until severe frost they are a sheet of bloom, if the seed pods are removed regularly. Violas are the best edging plants for the hardy border and are one of the most pleasing plants for the Children's Garden, the more flowers picked the better they bloom; do well in sun or shade.

Jersey Gem. New, deep violet blue.

Pkt. 50c

"Wild Garden" Flower Seed.*A. A wide variety of hardy flowering annuals mixed together, and wherever planted will insure something new almost every day. Is suitable for sowing in shrubbery, and in beds on which no care will be bestowed, or even for sowing in exposed locations, where wildness is preferred to order and precision. Seed may be broadcast on soil clean from weeds. To those who cannot give the necessary care required in a neatly laid-out flower garden, the "Wild Garden" presents a good substitute. You 
will be well repaid in giving this a place in your garden...............Pkt. 10c Zinnia ${ }^{*}$. . The Zinnia is one of the Linnia most brilliant, showy and satisfactory of annuals, and has long been a general favorite. The seed can be sown early in the hot-bed or light window and transplanted, or sown later in the open ground. It springs up quickly, and the young plants begin flowering early.

\section{Giant Dahlia Flowered}

Crimson Monarch. A splendid red of immense size, very showy........Pkt. 15c $\star$ Crown of Gold. A magnificent new strain of the Dahlia Flowered types in beautiful two-tone color harmony of rose, yellow, carmine and burnished red, each petal overlaid with deep golden yellow at the base. A most striking novelty.

Pkt. 25c

Dream. A deep lavender Zinnia of a most lovely color, combining delightfully with light rose and pink........Pkt. 15c

Exquisite. A delicate light rose shading to darker rose at the center. It is a very beautiful flower...........Pkt. 15c $\star$ Dahlia Flowered Golden Dawn. Enormous size, perfect type, golden yellow flowers ..................... 25c

Gold State. A striking shade of burnt orange. The distinct color and size of the bloom places it among the choicest of our summer and fall flowers.........Pkt. 15c $\star$ Dahlia Flowered Luminosa. Bright deep rose. The deepest and brightest of all the dahlia flowered rose shades

Pkt. 25c

Oriole. A combination of orange and gold that makes one of the most attrac-

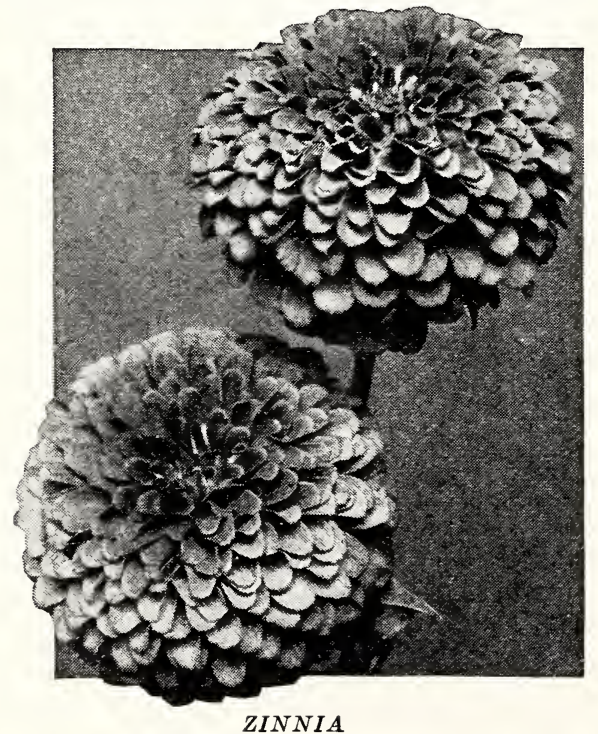

tive flowers. It changes slightly with age, but the color is always lovely.... Pkt. 15c

Polar Bear. A pure white, the result of years of hybridization. Deserving of a place in every garden..........Pkt. 15c

Purple Prince. A fine deep purple.

Pkt. 25c

Scarlet Flame. A large flower of beautiful bright scarlet. A soft blending of orange through the petals enriches its beauty ...................... 15k

Giant Dahlia Flowered Mixture. A good mixture...............Pkt. 15c

Kunderd's Special Mixture. This mixture is extra fine and is made up of named varieties of the Giant Dahlia Flowered Types...............Pkt. 25c

Kunderd's Giant Double Flowered Mixture ....................... 10k $\star$ Miss Wilmott. (California Giant.) A new color in the Mammoth flowering zinnias-a most delicate soft salmon pink. When in full bloom they make enormous show flowers-should be included in every collection of zinnias............Pkt. 15c $\star$ Pinkie. A new zinnia appropriately named "Cut and Come Again Pinkie" on account of producing a continuous succession of blooms throughout the summer. The flowers are a delightful shade of rosepink of medium size, very double, with long stems. The dainty form and color of Pinkie will make it very effective for mass bedding and desirable as a cut flower

Pkt. 25c

Lilliput-Zinnias

Lilliput-Zinnias. 12 inches. When in bloom is a mass of tiny, double, ballshaped flowers about 1 inch in diameter. Very bright. Mixed............Pkt. 10c ^Picotte Delight. A new Pumila type, very free flowering and of compact growth. Petals of flowers ruffled and curled giving a light and dainty effect with the objectional stiffness removed. Very striking for borders or bedding. Colors range through salmon shades, cream, golden yellow and lavender.

Pkt. 25c

Red Riding Hood. A beautiful little Pompome zinnia of dwarf habit of growth. Splendid for border. Brilliant scarlet flowers that bloom in profusion all summer.......................... 10kt

Salmon Rose. A new shade fine for cutting ................... Pkt. 10c

Golden Gem - Scarlet Gem - White Gem ................ Each per Pkt. 10c

\section{Regal Lily}

\section{(Lilium Regale)}

This wonderful, new, hardy lily was discovered in China by the late Mr. E. H. Wilson, of The Arnold Arboretum, Boston, and is still but little known to the general public. 
He tells of having seen it growing wild by the hundreds of thousands, exhaling its wonderful perfume, giving the air a delightful odor for miles around.

I have been so charmed with it that I am glad to be able to offer it to $m y$ customers. It grows to a height of from two to five feet with 3 to 12 and more massive blooms open at a time. Color a beautiful white with delicate, canary-yellow throat and a pinkish tint on the outside of the petals. It blooms in July and increases rapidly both from seed and bulb offsets. It is easy to grow from seed and will bloom the second year.

Grow Regal Lilies from Seed

This lily can be easily grown from the seed and is proving exceedingly popular as it is no doubt the finest of all lilies. I had scarcely enough to fill orders last year so please send your order early to avoid disappointment.

Seeds from the past season's crop are now ready at the following prices, prepaid:

Regal Lily Seeds-100 for 15c; 1000 for $85 \mathrm{c}$.

\section{REGAL LILY BULBS}

Small blooming size..15c ea. Medium size ......20c ea.

$\$ 1.50$ Doz. 2.00 Doz. Large size $\ldots \ldots \ldots \ldots 25$ ea.
Largest size $\ldots \ldots \ldots 35$ ea. Orders for bulbs accepted now for delivery October, $193^{2} 2$.

\section{Seeds for Rock Garden}

Agrostemma Coronaria Mixed (Mullien Pink) -1-2 ft. flowers, crimson and white, like a single Pink with silverywhite foliage...............Pkt. 10c

Alyssum Saxatile Compactum (Basket of Gold)-Showy bright yellow flowers, blooming from May to June. Height $1 \mathrm{ft} . . . \ldots \ldots \ldots \ldots \ldots . . . . . . . . . .10 \mathrm{c}$

Anemone Coronaria Mixed (Wind Flower) 9 in. Blooms in early spring....Pkt. 10c Aquilegia Coerulea (Rocky Mountain Columbine)-Sepals deep blue, petals white..................... 10c

Arabis Alpina-7-9 in. Early spring flowering plants covered with pure white flowers. Must have plenty of sun.

Pkt. 10c

Armeria Maritima (Sea Pink or Thrift)6 in. Flowers of a beautiful shade of pink, springing from tufts of narrow evergreen foliage............Pkt. 15c

Campanula Carpatica (Harebell) -8 in. Blue or white. Blooms the whole season.

Pkt. 10c

Candytuft (Iberis) Gibraltarica-10 in. Blush-white; flowers in early spring.

Pkt. 10c

Candytuft (Iberis) Sempervirens-Dwarf

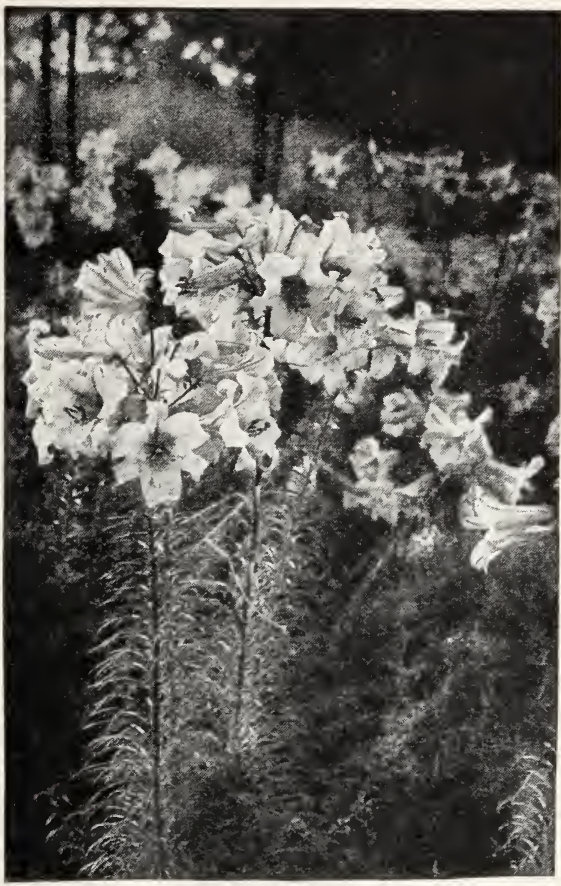

REGAL LILY

evergreen foliage covered with white flowers, blooming early in spring.

Pkt. 15c

Cerastium Tomentosum (Snow in Summer)-Dwarf white leaved plants bearing a profusion of small white flowers in May and June. 4 in..........Pkt. 15c

Dianthus Plumarius Cyclops - Hardy Dwarf Pink. Many beautiful colors with blood red eye. Blooms freely all summer. Especially suitable for rich gardens.................... 15k

Dianthus Plumarius Double Mixed (Scotch, Grass or Spice Pinks)-Excellent for rock gardens.........Pkt. 10c

Geum Mrs. Bradshaw-Large double brilliant scarlet flowers, blooming throughout the entire summer........Pkt. 15c

Gypsophila Repens-Dwarf white, 6 in. Blooms during June and July..Pkt. 15c Myosotis Palustris Semperfiorens-All summer bloomers, dark blue flowers.

Pkt. 15c

Linaria Cymbalaria (Kenilworth Ivy)3 in. Flowers lavender and purple. Trailing habit................ Pkt. 15c

Platycodon Mariesii Blue or WhiteLarge open bell shaped flowers.Pkt. 10c

Poppy Iceland Mixed $-1 \mathrm{ft}$. Bright green foliage with cup-shaped flowers borne on long stems. In bloom all summer.

Pkt. 10c 
Primula Japonica-Mixed........Pkt. 15c

Primula Polyanthus - Large flowered, mixed ...................... 15c

Primula Vulgaris (Common Primrose)Yellow ...................... 15c

Primula Auricula Alpine.........Pkt. 15c

Saponaria Occymoides Splendens-8-12 in. A showy creeping plant with bright pink flowers, blooming in May and June....................Pkt. 15c

Sedum Acre (Golden Moss)-2-3 in. Light green foliage covered with yellow flowers in May and July...Pkt. 15c Sedum Mixed-2-4 in...........Pkt. 15c Silene Schafta-4-6 in. July and Oct. Splendid rock garden plant with masses of pink flowers.............. Pkt. 15c

(Continued from Page 76)

cleaned about six weeks after digging, that is, to remove from the bulbs all roots and bulblets. To leave them on until planting time is an injury to the bulbs.

You will find these simple cultural directions amply sufficient to assure abundant returns. Try at least a small collection of the newer Gladioli in your garden this summer. Add to them from year to year and you will find no occupation more pleasant than the time you spend among these beautiful flowers.

\section{The Easy Garden Raiser}

The Easiest of Any Garden Cultivator to Operate

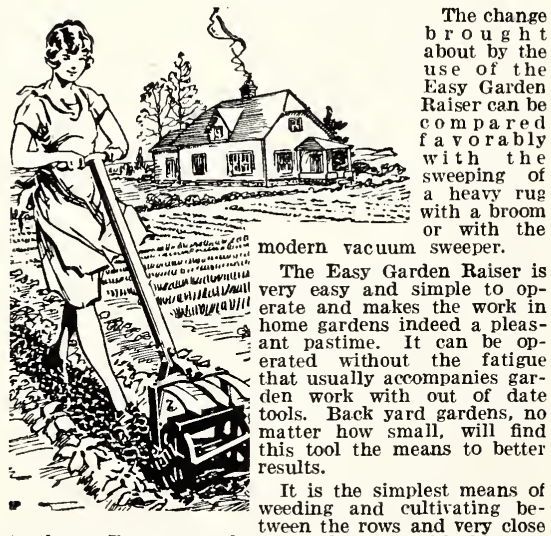

to them. Because of the easy cultivation with this tool you will not hesitate to give your garden more frequent attention which will mean better results, both for flowers and vegetables.

The one side carries with it a cutting blade, the other teeth similar to a harrow and the equipment includes guards for pushing plants back as you cultivate.

Further information upon request.

Price, $81 / 2$ inch width, $\$ 8.00$-prepaid Price, $10 \frac{1}{2}$ inch width, 8.50 -prepaid

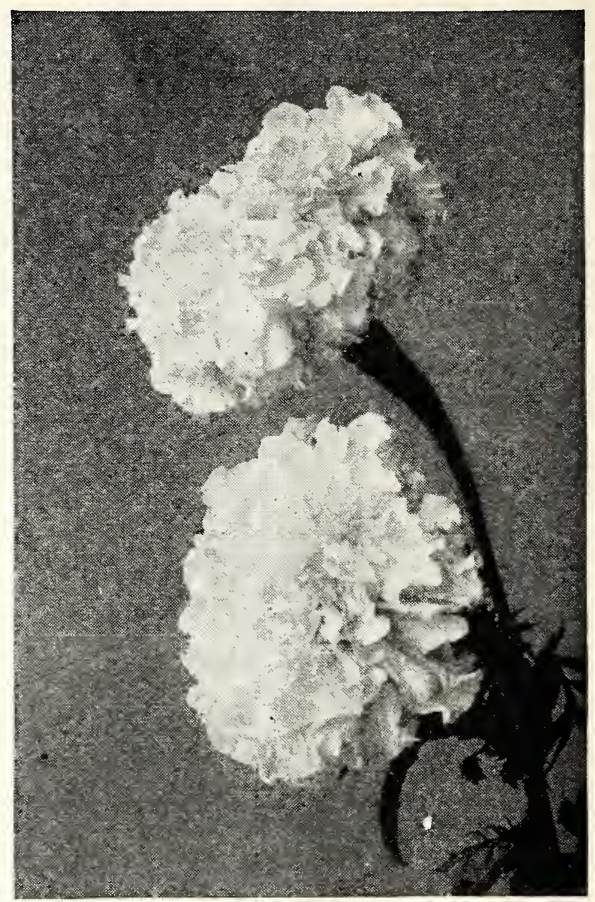

$M A R I G O L D$

\section{THE "YARD-BOY" INCINERATOR}

\section{The Right and Handy Way of}

Disposing of All Rubbish

Send for special information concerning the "Yard-Boy" Incinerator. Upon request, I will send you a special folder illustrating and describing the most practical Incinerator I have ever used or seen. It is durable, efficient and very practical and meets every requirement for quickly disposing of all outdoor rubbish.

This Incinerator has been tested and approved by the Good Housekeeping. Institute I am sure my customers will be well pleased by this inexpensive yet highly efficient manner of destroying unsightly rubbish.

\section{SIZES}

$11 / 2$ Bushels. .\$15.50

3 Bushels. $\$ 28.50$

6 Bushels. . $\$ 49.50$

Prices F.O.B.

South Bend, Ind.

A. E. KUNDERD

Goshen, Indiana

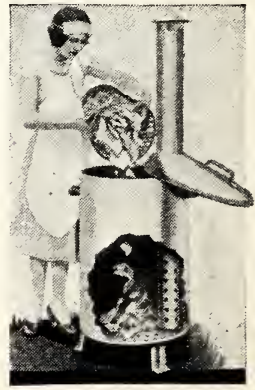




\section{Flower Seed Collections for Special Locations}

\section{ALLEY COLLECTION}

How often have you wondered just what you could do to conceal an unsightly alley or some other ugly location? Do you realize that for just a few cents in flower seeds you can transform these spots into places of beauty? Here is my collection of seeds that will do well in situations of this kind.

Bachelor's Buttons (Centaureas), mixed colors ..................... 10 c

California Poppy (Eschscholtzia),

Golden West .................. 10 c

Cosmos Early Flowering, mixed colors ........................ 10 c

Hollyhocks, mixed colors.............Pkt. 10c

Larkspur, Hyacinth Flowered Mixed..Pkt. 15c Price complete...........55c

\section{GARAGE BORDER COLLECTION}

"I'd like to plant something along the garage that would look very pretty," said Mrs. Housewife. This question has been stated a great many times so I have prepared a collection of flower seeds that will not only thrive well but will make a good appearance in a location such as this.

Hollyhocks, mixed colors.............. 10kt. Larkspur, Branching Mixed.............Pkt. 10c Marigold, Tall African Double Mixed.Pkt. 10c Petunia, Balcony Mixed..............Pkt. 15c Zinnias, Giant Dahlia Flowered Mixed.Pkt. 15c Price complete..........60

\section{PORCH OR WINDOW BOX COLLECTION}

This form of gardening is very popular especially to those who live where it is impossible to have an outdoor garden. Window and Porch Boxes can be made very attractive by using the flowers I have brought together in this Collection.

Alyssum, Little Gem.................. 10kt.

Nasturtium, Tom Thumb............Pkt. 10c

Pansy, Masterpiece .................. 15kt. 15

Petunia, Dwarf Fringed Rosy Morn...Pkt. 35c Price complete..........70c

\section{ANNUAL ROCK GARDEN COLLECTION}

Ageratum, Little Blue Star.........Pkt. 15c Alyssum, Little Gem................. 10kt. Candytuft, mixed ................... 10k California Poppy, (Eschscholtzia),

Golden West ..................... 10 c

Dianthus, Double and Single Pinks,

mixed ..................... 10

Golden African Daisy, Aurantiaca......Pkt. 10c Pansies, Giant Mixture................. 15k Phlox, Annual Mixed Varieties........Pkt. 10c Portulaca, finest double mixed.........Pkt. 10c Verbena, Gigantea mixed............... 20kt. Price complete.........\$1.20

\section{PERENNIAL ROCK GARDEN COLLECTION}

Alyssum Saxatile Compactum

(Basket of Gold)................. 10 c Arabis Alpina ...................... 10kt. Campanula Carpatica (Harebell).....Pkt. 10c Candytuft, (Iberis) Sempervirens....Pkt. 15c Dianthus, Plumarius, Double mixed..Pkt. 10c Geum, Mrs. Bradshaw..............Pkt. 15c
Myosotis, Palustris Semperflorens....Pkt, 15c Poppy, Iceland mixed................. 10kt. Primula Vulgaris (Common primrose).Pkt. 15c Price complete........\$1.10

\section{PARTIAL SHADY SPOT COLLECTION}

What shall I do with that partially shady spot in the garden? My! but I would like to grow pretty flowers there but I don't know what kinds to use. Perhaps you too have had a puzzling problem like this. There are quite a few fine flowers that will do well in shady situations and in this collection I am offering some of the most popular ones and kinds which will transform that shady place in your yard into a beauty spot.

Alyssum, Little Gem.................. 10c

Antirrhinum, (Snapdragons) Giant

Flowered Mixture .............. Pkt. 15c

Balsam, mixed varieties............. 10k

Centaureas (Bachelor's Button),

mixed colors .................... 10 c

Chinese For-get-me-not (Cynoglossum),

Amabile .....................Pkt. 15c

Pansies, Giant Flowered Mixture....Pkt. 15c

Petunia, Balcony Mixture..............Pkt. 15c Price complete.........90

\section{DRY SPOT COLLECTION}

Here again is a perplexing situation. What flowers can I successfully grow in a hot, dry situation? While of course most flowers desire considerable moisture there are certain kinds which will thrive well with but very little water. This collection contains such kinds of flowers and if you have a place of this description in your garden this collection will solve your problem.

Alyssum, Little Gem ...............Pkt. 10c

Calendula, mixed varieties............Pkt. 10c

California Poppy (Eschscholtzia),

Single mixed ................... Pkt. 10c

Petunia, Balcony mixed............Pkt. 15c

Phlox, Annual mixed varieties........Pkt. 10c

Poppy, Shirley mixed.................. 10kt.

Portulaca, Finest Double mixed........... 10kt. Price complete.........75c

\section{MOIST SPOT COLLECTION}

Take for instance that low spot where the ground always seems to be moist. Some of the flowers you have planted there have not been satisfactory while others may have done well. In this collection I am presenting my suggestions of flowers which will do well in situations such as this.

Ageratum, Little Blue Star..........Pkt. 15c

Antirrhinum (Snapdragon), Giant

Flowered Mixture ..............Pkt. 15c

Dianthus, Mixture Double and

Single Pinks ................... 10kt.

Mignonette ......................... 10

Nasturtium, Kunderd's Premier

Mixture of Tall...............Pkt. 10c

Pansies, Giant Mixture..................... 15kt

Petunias, Balcony mixed................ 15k Price complete.........90c 


\section{Please Read Carefully Before Ordering}

DISCOUNTS AND EXTRAS IN THIS CATALOG apply only to strictly retail Gladiolus orders and are figured on each individual order. That is, it is not possible to send orders at various times and then have the discount and extras figured on the combined orders.

WHEN MY CUSTOMERS DO NOT TAKE THE CASH DISCOUNT or select other gladiolus to the amount equivalent to the discount, my order department will send additional named varieties to balance this.

SEND ORDERS EARLY to be more certain of getting all varieties wanted. Late orders coming during my planting season may be delayed a few days. Please use the order blank sent with this catalog.

DO NOT HESITATE TO SEND SMALL ORDERS, even if for a single bulb. I want to help the smallest grower or beginner.

SAFE ARRIVAL OF BULBS IS GUARANTEED to any point within the United States and Canada. I care for the bulbs during the winter months and ship them as soon after February 15 th as the weather permits, but will make earlier shipment if you desire, sending the bulbs by express to insure against freezing. Such orders are sent express collect.

ALL GOODS ARE SENT TO YOU TRANSPORTATION PREPAID (except incinerators) at prices quoted in this book unless shipment is requested before regular shipping season, which starts about February 15 th.

CLAIMS FOR SHORTAGE must be made immediately upon receipt of goods.

SUBSTITUTION. Many years of experience have taught me the value of substitution, providing something similar or of greater value can be supplied. I find 99 out of 100 customers prefer this method, but if you do not wish any substitution please say so when ordering and any difference will be cheerfully adjusted.
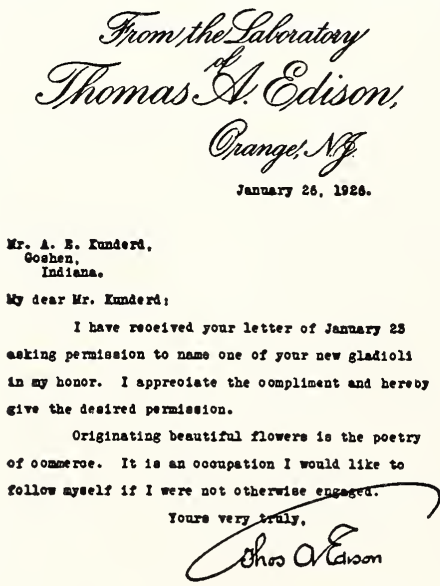

SUBSTITUTION IN COLLECTIONS. I reserve the right to substitute when out of a variety offered in any of the collections. The stocks are not of the same size and late in the season some may be entirely exhausted when your order arrives. Collections can be furnished only as described, at prices given. No alterations can be made in the collections described and offered in this book.

WHERE OFFERED BY THE DOZEN, six may be ordered at half the dozen price. Less than six at single rate. Where offered by the hundred, fifty will be supplied at the hundred rate. Less than fifty at single or dozen rate.

SPECIAL COLLECTIONS of named varieties (labeled) will be made up for any of my customers who may wish my aid in deciding what to plant. Nothing can make a finer present to a friend than a collection of choice Gladioli. Please state choice of colors, varieties you have grown and amounts you wish to buy.

FOREIGN SHIPMENTS. I cannot guarantee safe arrival to foreign countries (except Canada) due to the delay and risk in transit which is entirely beyond my control. Special effort will be made to ship in proper season, to send only first-class well-cured bulbs, also to pack well, but I cannot replace any stock arriving in unsatisfactory condition. From reports received from foreign customers, I find that over $95 \%$ of shipments arrive safely and in good condition. I can only accept Canadian and other foreign orders in American exchange. Please remit by international draft or money order either on New York or Chicago, in full value of American money. Canadian customers, be sure to give number of your import permit with each order and send me the shipping tag provided by your government. Canadian orders will be shipped with certificate of inspection from our State Entomologist as required by the Canadian Insect Pest Act.

TERMS: Remittances must accompany all orders in the amount of $\$ 2.00$ or less. Orders for more than this amount will be accepted on a deposit of $50 \%$ and will be shipped C.O.D. for the balance. Send bank draft, express or postal money order, or if more convenient for you I will accept your personal check. Unused U. S. stamps will be accepted in payment of orders amounting to less than $\$ 1.00$.

WHEN FULL REMITTANCE DOES NOT ACCOMPANY AN ORDER it will be sent C. O. D. for the balance. However, do not send balance later because the orders cannot be easily located after they are sent to the shipping department. Oftentimes even though the balance is sent the order passes through the shipping and mailing departments without being noticed and comes to you C. O. D. Then it is necessary to send refund.

REFERENCES. To those who may not know me, I refer by special permission to the following Goshen banks: The City National Bank, and the Salem Bank and Trust Co. Also R. G. Dun \& Co., and Bradstreet's Commercial Reports. 


\section{Gladioli Are Indexed Alphabetically}

\section{R-Ruffled P-Plain Petaled}

Pr-Primulinus

\section{L-Laciniated S-Snapdragon}

Page No.

Achievement, $r \ldots \ldots \ldots \ldots 2 i$ Achillas, $p$........... 34 Adair, $1, \ldots \ldots \ldots \ldots \ldots \ldots, 73$ Agnes Ball, p. $\ldots \ldots \ldots \ldots \ldots, \mathbf{3 4}$ Agnes Ball, Alice Tiplady, pr........6 6

Alton, $\mathbf{r} \ldots \ldots \ldots \ldots \ldots .21$

Ambrosia, $p$............. 34

Anna Mae, p.............

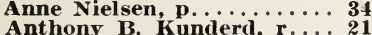

Anthony B. Kunderd, r....

Anthony Zonker, p.........

Antonia Antonette, p...... 35

Antonia Antonette, p.......

Arthur Brisbane, p.......

Arthur Cowee, p........ 35

Ashburn, p $\ldots \ldots \ldots \ldots \ldots \ldots .3$

Athene, pr $\ldots \ldots \ldots \ldots \ldots \ldots$ 6

Autumn colors, p.......... 35

Avalon, $r \ldots \ldots \ldots \ldots \ldots \ldots, 21$

Avant is, $p \ldots \ldots \ldots \ldots \ldots \ldots, 35$

Battle Creek, p......... 35

Beauty Flower, p........ 35

Beauty Wave, $r \ldots \ldots \ldots \ldots 21$

Big Black, $\mathbf{p} . \ldots \ldots \ldots \ldots \ldots \ldots \ldots \ldots$

Black Pansy, p.........

Black Pansy, p.............

Blue Isle, p..........

Blue Lily, p..........

Blushes of Cream, p...... 36

Blushing Beauty, r........21

Bobby, pooth Tarkingtou, $\ldots \ldots \ldots_{36}$

Booth Tarkington, p....... 36

Bridal Rose, r.......... 22

Bright Spots, p.......... 36

Brilliant Sun, p......... 36

Brown Lily, r........... 22

Buckeye, $\mathbf{r} \ldots \ldots \ldots \ldots \ldots \ldots{ }_{36}^{22}$

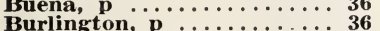

Burning Bush, $\mathbf{p} \ldots \ldots \ldots \ldots \ldots, 37$

Butterboy, pr $\ldots \ldots \ldots \ldots \ldots 67$

Byron L. Smith, p.......

Canary Feat her, r........ ${ }_{3}^{2}$

Capt. B. B. Lipsner, p......

Carmine Rose, p..........

Cattleya Rose, r........ 22

C. C. Sherlock, p.......

Chalice Flower, $\mathbf{r} \ldots \ldots \ldots \ldots$ 22

Challenger, p .............

Chantry, p $\ldots \ldots \ldots \ldots \ldots \ldots$. ${ }^{7}$

Charles F, Fairbanks, p... 37

Charm, $\mathbf{r} \ldots \ldots \ldots \ldots \ldots \ldots, 22$

Cherry Rose, p............

Chicago, $r \ldots \ldots \ldots \ldots \ldots \ldots, 22$

Chum, p $\ldots \ldots \ldots \ldots \ldots \ldots \ldots$ 1

Circe, $p$.............. 38

Clarise, $p \ldots \ldots \ldots \ldots \ldots \ldots \ldots \ldots, 38$

Claude Bovers, p........ 38

Col. Charles Lindbergh,,$\ldots 38$

Color Beauty, p......... 38

Color Marvel, r. $\ldots \ldots \ldots \ldots \ldots \mathbf{3}_{38}^{22}$

Colors, p $\ldots \ldots \ldots \ldots \ldots \ldots \ldots, \mathbf{3 8}$

Consolation, p $\ldots \ldots \ldots \ldots \ldots$ 17

Contemplation, $\mathbf{r} \ldots \ldots \ldots \ldots 23$

Contentment, $r$......... 17

Contrasta, $p \ldots \ldots \ldots \ldots \ldots .39$

Copper Bronze, pr. $\ldots \ldots \ldots \ldots$
Coral Pink, r....

Coral Pink, r.......... 23

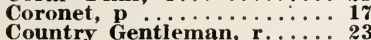

Cream Cups, p............ 39

Cream Puff, p............ 39

Crinkles, $\mathbf{r} \ldots \ldots \ldots \ldots \ldots .23$

Cyprian, $\mathbf{r} \ldots \ldots \ldots \ldots \ldots \ldots \ldots \ldots \ldots$

Dainty Lily, p.......... 39

Darling O'Mine, p......... 39

Delicacy, $p$. ........... 39

Dew of Heaven, p....... 39

Dixie Girl, p............ 39
Page No.

Dominus, $p$

Dream, r $\ldots \ldots \ldots \ldots \ldots \ldots 23$

Dream Flower, $p \ldots \ldots \ldots \ldots$ 40

Dr. Elkins, $p \ldots \ldots \ldots \ldots, 40$

Dr. J. H. Neeley, p. $\ldots \ldots \ldots, 40$

Dr. L. H. Bailey, r. . . . . 23

Dr. Nelson Shook, $r \ldots \ldots \ldots, 23$

Duchess, $p$.............. 40

Dusky $_{\text {, p }} \ldots \ldots \ldots \ldots \ldots \ldots, 17$

E.C. Viek, r.........

Ed. Springer, p......... 40

Ghaylor, r..........

E. Shaylor, $\mathbf{r} \ldots \ldots \ldots \ldots \ldots, \mathbf{z}_{\mathbf{2 4}}$

Eiba, $r, \ldots \ldots \ldots \ldots \ldots \ldots, 44$

Embers, $r \ldots \ldots \ldots \ldots \ldots \ldots$ q

Emblem, $p$............ 41

Enchantress, pr $\ldots \ldots \ldots \ldots$ 68

Encore, pr $\ldots \ldots \ldots \ldots \ldots \ldots, 6 \%$ 61

Cnigma, $p \ldots \ldots \ldots \ldots \ldots \ldots \ldots, 41$

Estella, $p \ldots \ldots \ldots \ldots \ldots \ldots$ 41

E. T, Barnes, p...........

Evening, pr $\ldots \ldots \ldots \ldots \ldots \ldots$ 68

Evening Glow, $p_{\ldots} \ldots \ldots \ldots$ 41

Evangeline Bootl, $r . . \ldots .24$

Excellence, $p \ldots \ldots \ldots \ldots, 41$

Fairest Pearl,

Fairest white, p......... 41

Fairfield, $p$............. 41

Fairmont, $p \ldots \ldots \ldots \ldots \ldots$ 41

Fairview, p $\ldots \ldots \ldots \ldots \ldots$ 42

Favn Gold, $\mathbf{p} \ldots \ldots \ldots \ldots \ldots \ldots$ 42

Fern Kyle, $r \ldots \ldots \ldots \ldots \ldots \ldots, 24$

Fiancee, $p \ldots \ldots \ldots \ldots \ldots$ 42

Fire Glow, $\ddot{p} \ldots \ldots \ldots \ldots \ldots \ldots$ 42

Fire Pink, $p \ldots \ldots \ldots \ldots \ldots$ 42

Fire Ribbon, $p \ldots \ldots \ldots \ldots$ 4 2

Flaming Vale, $p \ldots \ldots \ldots \ldots$ 42

Florence Winter, $r \ldots \ldots \ldots \ldots$ 24

Fuld's Favorite, p........ 42

Gaiety $\mathbf{p}, \ldots \ldots \ldots \ldots \ldots \ldots \ldots \ldots, 42$

Georgia (K's), p $\ldots \ldots \ldots \ldots$ 42

Gloaming, $p$......... 43

Glorious, $r \ldots \ldots \ldots \ldots \ldots 24$

Golden Anniversary, $\mathbf{r} \ldots \ldots 24$

Golden Apricot, $p \ldots \ldots \ldots$ 43

Golden Arc, pr $\ldots \ldots \ldots \ldots$ 68

Golden Beauty, $\mathbf{r} \ldots \ldots \ldots \ldots$ 24

Golden Frills, pr ......... 68

Golden Fringe, $p \ldots \ldots \ldots \ldots 43$

Golden Gleain, pr ........68

Golden Glory, $r \ldots \ldots \ldots \ldots$ 24

Golden Harmony, pr . . . . . 68

Golden Light, pr $\ldots \ldots \ldots$ 68

Golden Orange, pr $\ldots \ldots \ldots 6.68$

Golden Rose, p ........... 43

Golden Shapdragon,,$\ldots \ldots$ r 18

Golden Tinge, pr . . . . . . . 68

Good Morning, $r \ldots \ldots \ldots \ldots$ 25

Gordon L. Pirie, $\mathbf{p} \ldots \ldots \ldots$ 4,3

Gorgeous, p $\ldots \ldots \ldots \ldots \ldots$ 44

Gov, Einmerson,,$\ldots \ldots \ldots \ldots 44$

Gov. Einmerson, p $\ldots \ldots \ldots \ldots$ 44

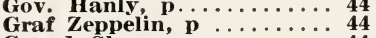

Grand Glory, p..........

Graphic, $p \ldots \ldots \ldots \ldots \ldots \ldots, \mathbf{4 4}$

Greetings, $\mathbf{p} \ldots \ldots \ldots \ldots \ldots \mathbf{1 8}$

Haughty, $p$............. 44

Helen Keller, $\ldots \ldots \ldots \ldots \ldots \ldots, 44$

Helen M., p............ 18

Herald, $p$. . . . . . . . . . .

Herbert Hoover, p....... 44

Hermes, $r$, $\ldots \ldots \ldots \ldots \ldots 25$

H. H. Groff,

H. H. Groff, pdie, $\ldots \ldots \ldots \ldots$ 45

Holy Grail, $\ldots \ldots \ldots \ldots \ldots, 45$

Hoosier Pearl, pr..........

Hugo Eckener, p......... 45

Hummer, $\mathbf{r} \ldots \ldots \ldots \ldots \ldots .18$

Hyperion, 1 . . . . . . . 73

Ida Van, $p \ldots \ldots \ldots \ldots \ldots \ldots, 45$
Page No.

Immerium, p $\mathbf{p} \ldots \ldots \ldots \ldots \mathbf{4 5}$

Impresario, 1 , $\ldots \ldots \ldots \ldots \ldots \ldots$.

Indian, $p$, . . . . . .

Indian Clief, $\mathbf{p}, \ldots \ldots \ldots \ldots \ldots, 46$

Indian Summer, $r \ldots \ldots \ldots 25$

Intensity, r $\ldots \ldots \ldots \ldots \ldots \ldots, \mathbf{2 5}$

Intramura, $\mathbf{p} \ldots \ldots \ldots \ldots \ldots \ldots \ldots \ldots$

Iroquois, $p$. . . . . . . . . . 46

Jacelia, p sheldon, $p \ldots \ldots$ 46

Jap, pr .............. 69

J. F. Rosenfield, p...... 46

J. Harry Selz, p........ 46

J. Horace MeFarland, p. . . 46

J. J. Mitchell, p....... 46

J. Ogden Armour, r......

John Dunbar, p......... 4r

John T. MeCutcheon, p.... 47

John T. Yírie, p..........

Joseph J. Lane, p.........

Joy, $\mathbf{r}$ Julius Rosenwali, $\mathbf{r} \ldots \ldots \ldots$ 26

June Moth, p ......... 26

June Night, p............ 47

Kasson, $r \ldots \ldots \ldots \ldots \ldots \ldots, 26$

Kilima, $p \ldots \ldots \ldots \ldots \ldots, \mathbf{4}^{\gamma}$

King of Oranges, pr...... 69

Kunderdii Glory,
K's Apple Blossom, . . . . . . . 26

K's Wild Rose $r \ldots \ldots \ldots \ldots 26$

K's Yellow Favorite, p..... 47

K's Yellow Wonder, p...... 47

Lacinatus, 1 ...........73

Lady Pink, p........... is

Laughter, p ............. 18

Lavender America, $p \ldots \ldots .47$

Lavender Frills, $r$. . . . . 26

Lavender Pride, $r \ldots \ldots \ldots .26$

Lavender Rose, p......... 48

Leen Wone, pr...........6.

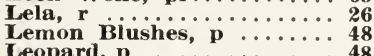

Lewis E. Gary, p........48

Lexington, $p, \ldots \ldots \ldots \ldots, 48$

Lilac Glory, $\mathbf{r} \ldots \ldots \ldots \ldots \ldots .26$

Lilith, $r$

Lily of Gold, $\mathbf{r} \ldots \ldots \ldots \ldots \ldots, 26$

Little Red Star, $\ddot{p} \ldots \ldots \ldots \ldots$. 48

Loella, $p \ldots \ldots \ldots \ldots \ldots \ldots, 48$

Lohengrin, $p \ldots \ldots \ldots \ldots \ldots, 18$

Louis $F$. Swift, p....... 48

Lullaby, pr . . . . . . . . 69

Lustre, p . . . . . . . . 50

Luxury, $p \ldots \ldots \ldots \ldots \ldots 50$

Lyric, pr $\ldots \ldots \ldots \ldots \ldots \ldots, 18$

Magnifica, $\ddot{p} \ldots \ldots \ldots \ldots \ldots \ldots$. 50

Magnificent, $p \ldots \ldots \ldots \ldots 50$

Mahogany, p........... 50

Mahogany King, p....... 50

Marigold, pr $r \ldots \ldots \ldots \ldots$,

Marie Kunderd, $\mathbf{r} \ldots \ldots \ldots$. 27

Marilyn, $\mathbf{p} \ldots \ldots \ldots \ldots \ldots .18$

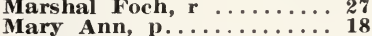

Mary Ann, p............ 18

Mary Fennell, p .......... 50

Mary Jane, $p \ldots \ldots \ldots \ldots \ldots$ 50

Mary Pickford, p ........ 51

Mast erpiece, $\mathbf{r} \ldots \ldots \ldots \ldots .27$

Meadow Lark, $\mathbf{r} \ldots \ldots \ldots \ldots \ldots$ 27

Merton w. Wentworth, $\mathbf{p}$. 51

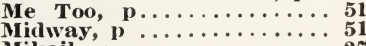

Millionaire, p

Ming Toy, pr

Mirage, $p$

Miss Muskegon, p $\ldots \ldots \ldots 19$

Miss Universe, p.........

Modern Beauty, $\mathbf{p} \ldots \ldots \ldots \ldots$ 52

Modesty, p .......... 52 
Mommie Dietz, p......... 5 Mona Lisa, $r$, p.......... Mongolia, pr $\ldots \ldots \ldots \ldots \ldots$ 69

Monnie, $\mathbf{p} \ldots \ldots \ldots \ldots \ldots$ 52

Morning Sunshime, $\mathbf{r} \ldots \ldots \ldots$ 27

Mottled Feather, p....... 52

Mrs. Arthur Meeker, $\mathbf{p} . \ldots \ldots$ 52

Mrs. Calvin Coolidge, pr... 69

Mrs. Chas. A. Stevens, p... 52

Mrs. Dr. Bevan, r....... 27

Mrs. Dr. Norton, p...... 52

Mrs. E. A. Hamill, p..... 52

Mrs. Frank Pendleton, p... 52

Mrs. Geo. W. Hay, p..... 53

Mrs. Geo. W. Moulton, p.. 53

Mrs. John T. Pirie, p..... 53

Mrs. Laurance Armour, r... 28

Mrs. Walt er Lytton, $\ldots \ldots \ldots 5$

Mrs. Waiter Lytton, p.....

Mystery, $\mathbf{p} \cdots \ldots \ldots \ldots \ldots \ldots$

Natalie, $r$ r $\ldots \ldots \ldots \ldots \ldots, \underset{28}{28}$

New York, $r \ldots \ldots \ldots \ldots \ldots, 28$

Northern Light, p....... 53

October, $p$........... 53

Odyssee, $p$. . . . . . . . . 53

oh Promise Me, pr....... 70

Opal Fringe, p......... 5

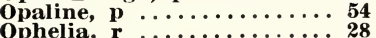

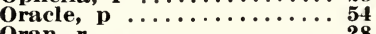

Orange Feather, $\mathbf{r} \ldots \ldots \ldots$ 28

Orange Feather, $\mathbf{r} \ldots \ldots \ldots \ldots$
Orange Fires, $\mathbf{r} \ldots \ldots \ldots \ldots$

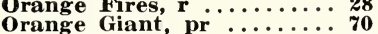

Orange Lily, $\mathbf{r} \ldots \ldots \ldots \ldots \ldots$. 28

Orange Plume, $\mathbf{p}_{\ldots \ldots \ldots \ldots} . \ldots \ldots$

Orchid Butterfy, r........ 28

Orchidian $p$

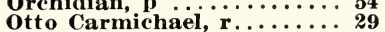

Pal o'Mine, p............ 54

Pantheon, $p$...........

Paramount, $p \ldots \ldots \ldots \ldots \ldots \mathbf{5 4}$

Patricia Carter, pr.......

Paula, $r$............... 19

Paula, $\mathbf{r}$ Kunderd, $\ldots \ldots \ldots \ldots$ p4

Peach Blushes, p ........ 54

Peach Bud, $p$.......... 54

Peach Glow, $p \ldots \ldots \ldots \ldots$ 55

Peacock, $\mathbf{p}, \ldots \ldots \ldots \ldots \ldots \ldots$. ${ }_{29}$

Persepolis, p $\ldots \ldots \ldots \ldots \ldots \ldots$ 55

Persepolis, p $\ldots \ldots \ldots \ldots \ldots \ldots \ldots \ldots$ 55

Philat elia, p $\ldots \ldots \ldots \ldots \ldots$ 55

Phyllis Cloetingh, pr....... y0

Pierian, $1 \ldots \ldots \ldots \ldots \ldots \ldots$ 74

Pink Beam, $\mathbf{p} \ldots \ldots \ldots \ldots \ldots \ldots$ 29

Pink Clover, $p \ldots \ldots \ldots \ldots \ldots$. 55

Pink Delight, p $_{\text {Pink }} \ldots \ldots \ldots \ldots \ldots$....

Pink Enchantor, $\not$ p $\ldots \ldots \ldots$. 56

Pink Favorite, p ........ 56

Pink Lily, $\mathbf{r} \ldots \ldots \ldots \ldots \ldots, \mathbf{2 9}$

Pink Witch, p ........... 19

Planada, $p, \ldots \ldots \ldots \ldots \ldots \ldots$. 6

Pompeian Beauty, p...... 56

Pond Lily, p...........

Predominator, $p \ldots \ldots \ldots \ldots \ldots$ : 56

Pride of Goshen, $x \ldots \ldots \ldots$ 29

Primora, $\mathbf{r}$. $\ldots \ldots \ldots \ldots \ldots \ldots$.

Prof. C. S. Sargent, ${ }_{\text {Prof. }} \ldots \ldots \ldots 56$

Prof. E. Fe Beauty, p $\ldots \ldots \ldots \ldots$
Purple Challenge, $\mathbf{p} \ldots \ldots \ldots$
Page No.

Purple Crown, $\mathbf{p} \ldots \ldots \ldots \ldots$ 5

Purple Glory, $\mathbf{r} \ldots \ldots \ldots \ldots$. 29

Purple Pansy, p......... 5

Purple Progress, p ....... 5

Purple oueen, $r \ldots \ldots \ldots \ldots$ rg

Purple Spot, p...........

Quantico, $r$ r $\ldots \ldots \ldots \ldots \ldots$. 29

Quartin Dillon, p........

Rajah, p .............

Ramona, pr ........... 70

Red Beauty, $\ddot{p} \ldots \ldots \ldots \ldots \ldots \ldots$ 5

Red Butterfiy, $\dot{p} \ldots \ldots \ldots \ldots .58$

Red Cardinal, p . ......... 58

Red Charm, p $\ldots \ldots \ldots \ldots \ldots \mathbf{5 8}$

Red Cloud, p $\ldots \ldots \ldots \ldots \ldots$.

Red Commander, $\mathbf{p} \ldots \ldots \ldots$. 58

Red Copper, p .......... 58

Red Darling, p $\ldots \ldots \ldots \ldots \ldots$. 58

Red Empire, p . . . . . . . . . 58

Red Fire, p $\ldots \ldots \ldots \ldots \ldots \ldots$ 58

Red Orange, pr $\ldots \ldots \ldots \ldots$

Red Ribbon, $\mathbf{r} \ldots \ldots \ldots \ldots \ldots, 29$

Red Roamer, p . . . . . . . 58

Red Rock, p ............ 59

Red Rose, p ............. 59

Red Splendor, $\mathbf{r} \ldots \ldots \ldots \ldots$ 30

Red Velvet, p $\ldots \ldots \ldots \ldots \ldots$ 59

Renata, p ................

Reo, $\mathbf{r}, \ldots \ldots \ldots \ldots \ldots \ldots \ldots, \ldots, \ldots, \ldots$

Rhapsod $\mathbf{y}, \mathbf{p} \ldots \ldots \ldots \ldots \ldots \ldots \ldots \ldots$

Robert J. Kunderd, $\ldots \ldots \ldots$ s9

Robinette, $p$............ 59

Rolling Prairie, $\mathbf{p} \ldots \ldots \ldots \ldots \mathbf{5 9}$

Roman Candle, $p$....... 59

Romance, $p$............ 59

Rosalind, $r \ldots \ldots \ldots \ldots \ldots, 30$

Roscoe Huff, $\mathbf{r}, \ldots \ldots \ldots \ldots \ldots$. 19

Rose, $p \ldots \ldots \ldots \ldots \ldots \ldots \ldots$. 59

Rosea, $\mathbf{p}, \ldots \ldots \ldots \ldots \ldots \ldots \mathbf{6 0}$

Rose Ann, p........... 60

Rose Glory, $r . \ldots \ldots \ldots \ldots \ldots, 30$

Rosemary Hayes, $\mathbf{r} . \ldots \ldots \ldots$ 30

Rosemary Hayes, r........

Rose Pearl, p $\ldots \ldots \ldots \ldots \ldots$ 60

Rose Splendor, p .........6 60

Rosy Glow, $p \ldots \ldots \ldots \ldots \ldots 60$

Rosy Smoke, p .........6 60

Royal, $p \ldots \ldots \ldots \ldots \ldots \ldots$. 60

Royal Beauty, p ........6 60

Royal Purple, p ..........6 60

Rozan Marie, p..........6. 61

Ruffled Splendor, $\mathbf{r} \ldots \ldots \ldots$ 30

Ruth Huntington, $r \ldots \ldots \ldots 30$

Saffron King, pr.........

Salmon Buff, pr ........ 71

Salmon Fins, p . . . . . . 61

Salmon Plume, $\mathbf{r} \ldots \ldots \ldots \ldots . .30$

Salmon Ruffles, $r \ldots \ldots \ldots \ldots$, 30

Salmon Star, p .......... 61

Sammy Lane, p.......... 61

San Francisco, p....... 61

Scarlet Glory, $\mathbf{r} \ldots \ldots \ldots$ 30

Scarlet King, p ........6.61

Scarlet Princeps, p........61

Seaside, $p \ldots \ldots \ldots \ldots \ldots 19$

Senator Beveridge, p..... 61

Shell Pink, pr........... 71

Show Flower, p........6. 61

Silver Cloud, $\mathbf{p} \ldots \ldots \ldots \ldots .62$

Silver Comet, p..........

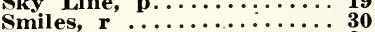

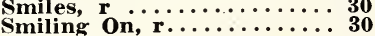

Page No.

Snapdragon, $s \quad \ldots \ldots \ldots \ldots \ldots$ Page No

Snow Boy, p ...........62

Snow Flake, p.......... 62

Snow Glory, $\mathbf{r} \ldots \ldots \ldots \ldots, 31$

Song of the Lark, $r \ldots \ldots \ldots 31$

Southern Beauty, r....... 31

Southland Queen, r....... 31

Spangled Beauty, p...... 62

Spectrum Beauty, p......6 62

Spirit of $, 76, p . \ldots \ldots \ldots \ldots 62$

Splendor, $1, \ldots \ldots \ldots \ldots \ldots, 62$

Splendorra, $\ddot{p} \ldots \ldots \ldots \ldots \ldots, 62$

Star Lily, $\mathbf{r} \ldots \ldots \ldots \ldots \ldots \ldots, \ldots,{ }_{31}$

Stippled Beauty, pr....... 71

St. Thomas, p.......... 62

Stuart Merrill, p.........6 62

Sulphur Frills, r........ 31

Sulphur Glow, $\mathbf{r}, \ldots \ldots \ldots \ldots, \mathbf{3 1}$

Sun Glow, p $\ldots \ldots \ldots \ldots \ldots \ldots, 63$

Sun Rest, $p$.............6.

Sunrise, $p$............6.

Swan, $p \ldots \ldots \ldots \ldots \ldots \ldots$. 19

Sweet Cherry, p.........6.

Sweeter Seventeen, pr..... 71

Sweet Rose, p..........

Symbol, $p$................6.

Syncopation, $\mathbf{p r}, \ldots \ldots \ldots \ldots \ldots$ z1

Tanager, $\mathbf{r} \ldots \ldots \ldots \ldots \ldots .31$

Taro, $p$............. 63

Taurus, pr $\ldots \ldots \ldots \ldots \ldots \ldots$ 71

T. A. Weston, p........6. 63

Temblor, pr $\ldots \ldots \ldots \ldots \ldots$ 71

Tempa, $r$ pre.......

Thistle, $\mathbf{r} \ldots \ldots \ldots \ldots \ldots \ldots \ldots, 32$

Thomas $A$. Edison, $\mathbf{r} \ldots \ldots \ldots$ 32

Thought, p $\ldots \ldots \ldots \ldots \ldots \ldots 19$

Tiger, $\mathbf{p} \ldots \ldots \ldots \ldots \ldots \ldots$ 63

Tiger King, p...........64

Tippecanoe, $\mathbf{r} \ldots \ldots \ldots \ldots .32$

Today, pr $\ldots \ldots \ldots \ldots \ldots \ldots$ 71

Toledo, $p$. . . . . . . . . 64

Torpedo, $\mathbf{p} \ldots \ldots \ldots \ldots \ldots \ldots \ldots, 6 \times \ldots$

Trianon, $p$. $\ldots \ldots \ldots \ldots \ldots$ 64

Turkey Run, p........ 64

Tyrian Beauty, p.........

Tyrian Rose, p............6

Uhlan Chief, $p . \ldots \ldots \ldots \ldots \ldots, 64$

Ulrica, pr . . . . . . . . . . .

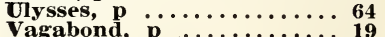

Varro $\mathrm{p}, \ldots \ldots \ldots \ldots \ldots$

Velvet Diamond, $\mathbf{p} \ldots \ldots \ldots \ldots$ 64

Vermilion, $\mathbf{p}, \ldots \ldots \ldots \ldots, 6,64$

Viola Gem, $p \ldots \ldots \ldots \ldots \ldots, 65$

Violet Glory, $\mathbf{r} \ldots \ldots \ldots \ldots \ldots \ldots, \mathbf{3 2}$

Violet Prince, p......... 65

Virginia Hale, $p . \ldots \ldots \ldots \ldots \ldots 65$

Virginia Lou, pr..........

Watermelon, $\mathbf{p} \ldots \ldots \ldots \ldots 6 \mathbf{6 5}$

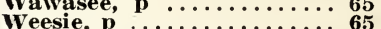

Western ${ }_{\text {Wtar, }}$ p.........

Western Sunset, $r \ldots \ldots \ldots \ldots \ldots$ 32

White Butterfly, pr........

White Feather, $p \ldots \ldots \ldots \ldots$ 65

White Glory, $\mathbf{r} \ldots \ldots \ldots \ldots \ldots, 32$

White Pigeon, p........6.65

William Booth, p........6. 65

Wm. Randolph Hearst, p... 65

Wonderful, $p \ldots \ldots \ldots \ldots$......... 65

Wonder Glory, $\mathbf{r} \ldots \ldots \ldots \ldots \ldots$ 32

Yellow Frills, pr $\ldots \ldots \ldots \ldots$ 72

Youell's Favorite, $\mathbf{r} . \ldots \ldots \ldots$. 32

Yukon, $\mathbf{r} \ldots \ldots \ldots \ldots \ldots \ldots . .19$

Zona, pr $\ldots \ldots \ldots \ldots \ldots \ldots \ldots \ldots \ldots, 72$

\section{USEFUL BOOKS ON FLORAL SUBJECTS}

The Gladiolus, by F. F. Rockwell

Paper bound copy.............\$0.65

Garden Guide

Paper bound copy...............\$1.15

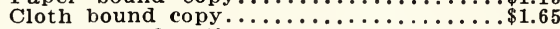

1001 Garden Questions Answered, by Prof. Alfred C. Hottes

Paper bound copy ................\$1.65

Cloth bound copy.................\$2.15

The Book of Annuals, by Prof. Alfred C. Hottes

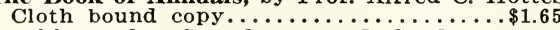

Fertilizers for Greenhouse and Garden Crops, by Alex Laurie and J. B. Edmond

Cloth bound copy..................\$2.15

The Rock Garden Primer, by Archie Thornton

Cloth bound copy...................\$2.15
The Book of Perennials, by Prof. Alfred C. Hottes

Cloth bound copy...............\$1.65

The Woman's Flower Garden-Indoor and Outdoor, by Jane Leslie Kift

Cloth bound copy................\$1.35

All About Flowering Bulbs, by T. A. Weston Cloth bound copy...................\$2.15

The Principles of Flower Arrangement, by Prof. E. A. White

Cloth bound copy...............\$3.15

Our Native Cacti, by Ethel Bailey Higgins

Cloth bound copy.................\$2.65

These prices are all postpaid to you. 


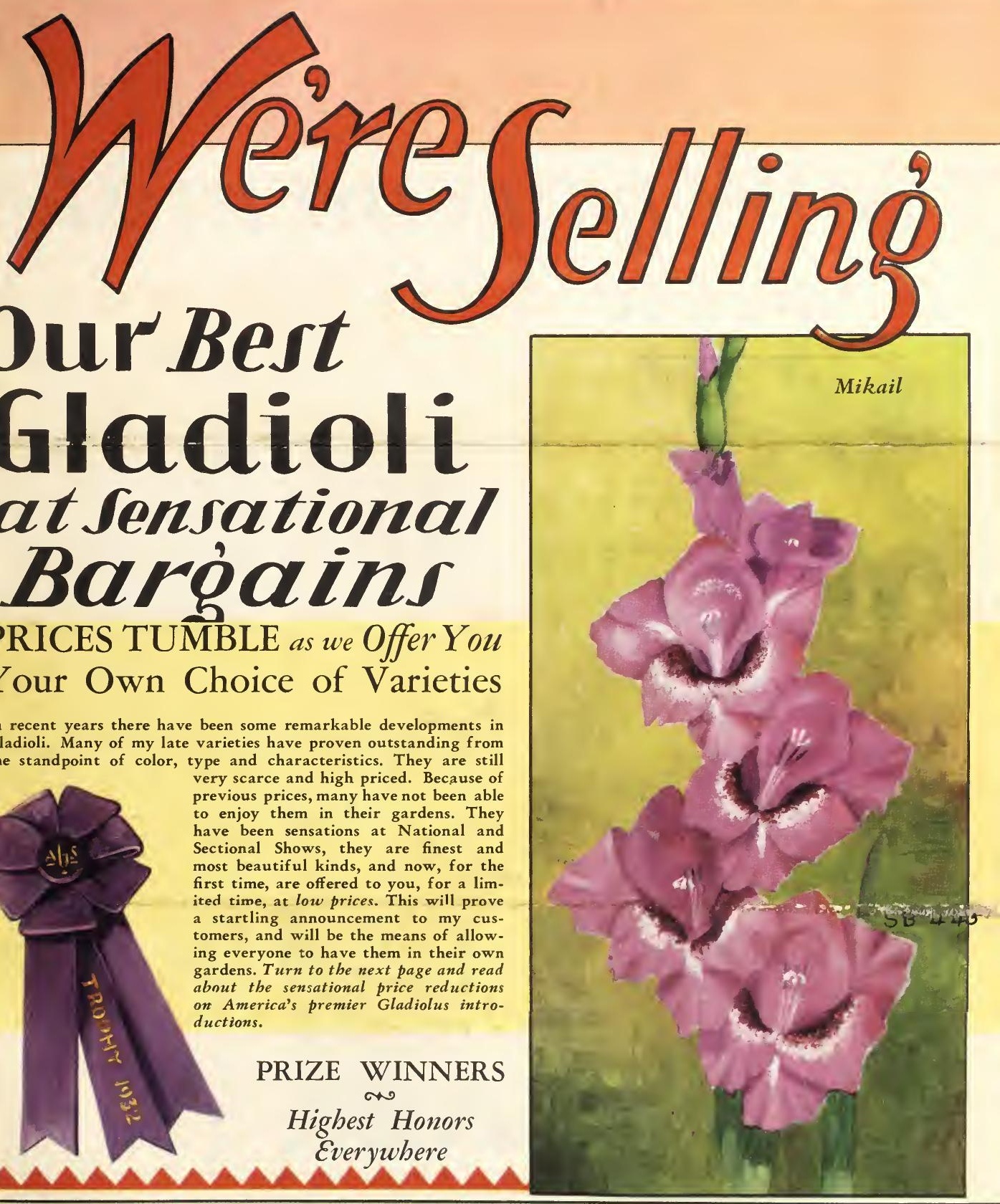

Kunderd's Deluxe Gladioli 
The OpportunityYou HaveWaited For NOW you can make up your own Collection from the ARISTOCRATS of American Flower's.

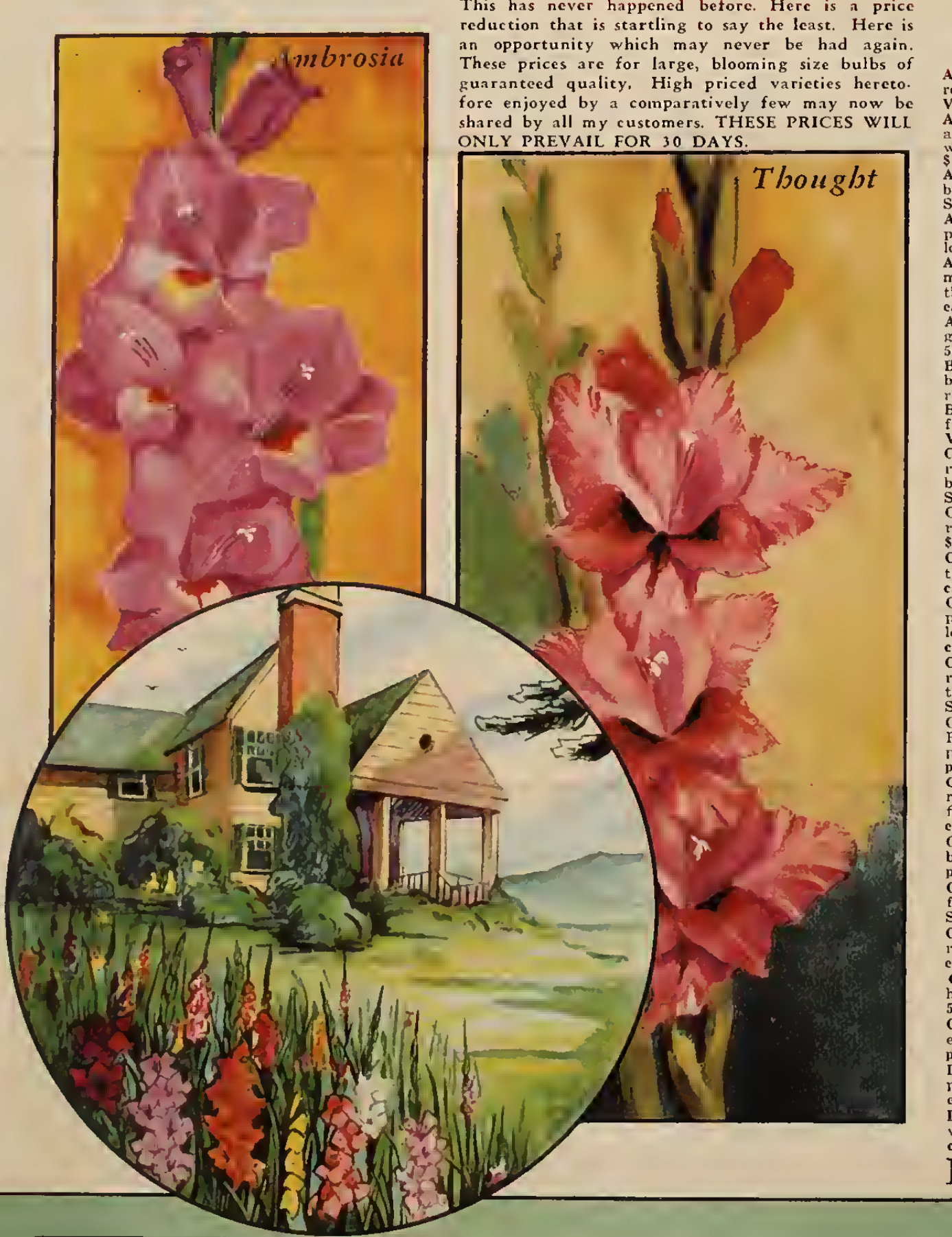

PLEASE USE THE ORDER BLANK ON BACK PAGE

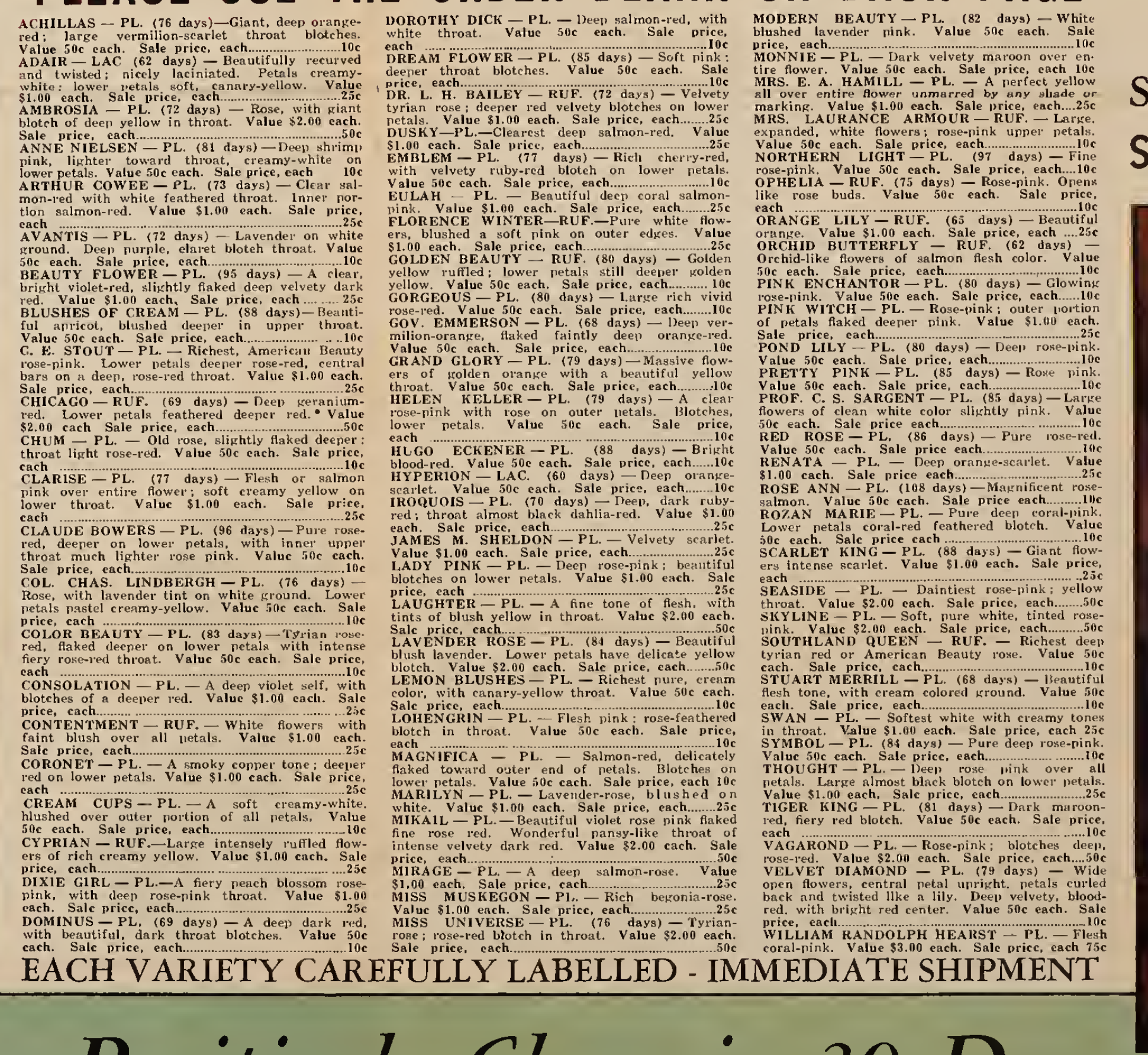

This Offer

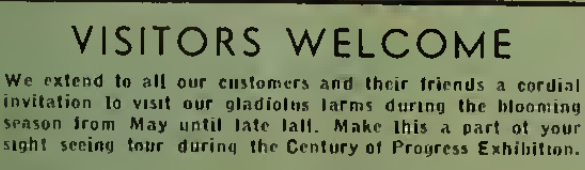

ALL GLADIOLI SHIPPED PREPAID

Safe Arrival Guaranteed

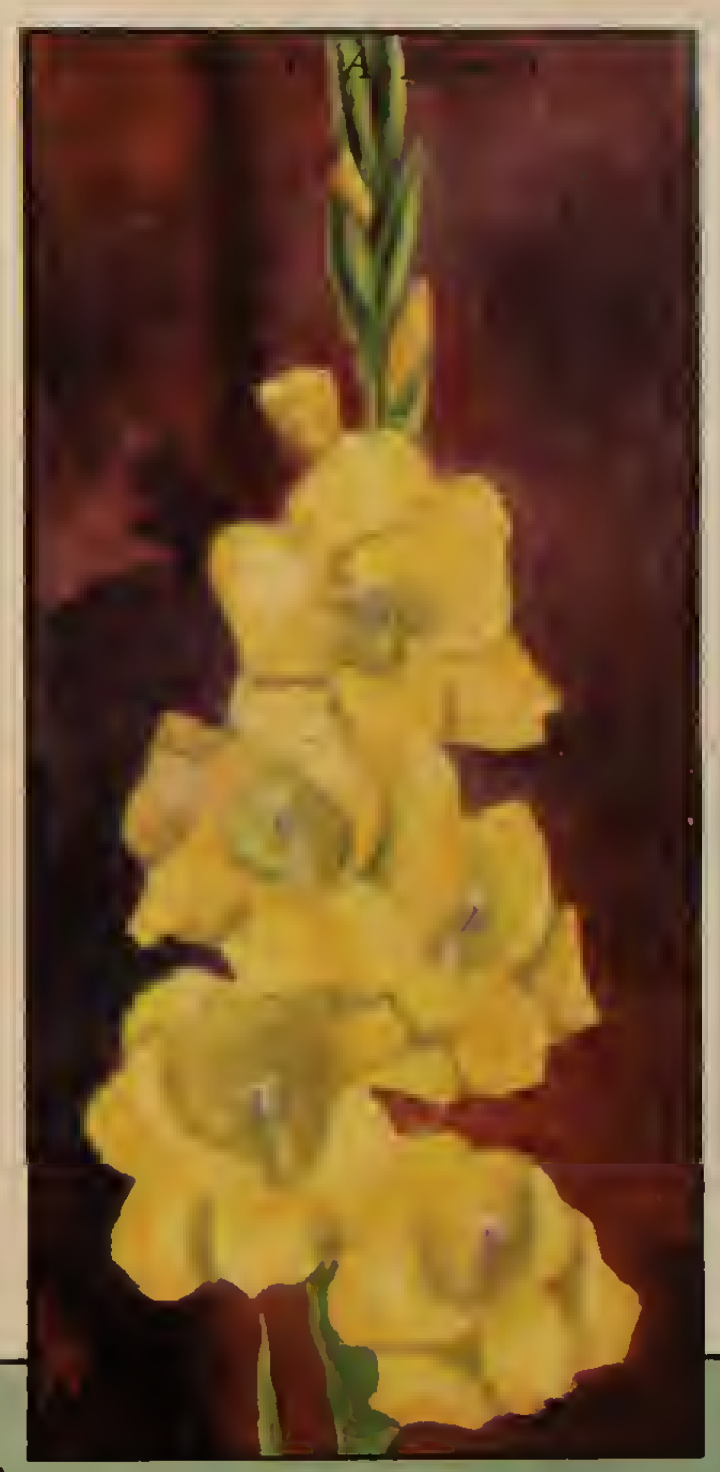

Values to $\$ 3.00$ 
A. E. Kunderd, Goshen, Ind., U. S. A.

Please forward to

Name

Street

Post Office

Amount inclosed, $\$$

R. F. D. No.

P. 0. Box

County

State

Express Office

Date of Order

193

Please write name and address plainly, and fill in all blanks carefully, attach price to each article and add up accurately. If no objection, We substitute a similar or better variety when out of kinds
Order tearly. QUANTITY

VARIETY ORDERED

PRICE Dollars Cents for only 75 cents each

\section{New 1933 Introductions}

Many of my customers who have missed seeing my 1933 Introductions in my catalog this year will be delighted by this announcement. While fewer in number, the quality is exceptional. I present rare and beautiful things for 1933 , in fact they are among the finest it has ever been my privilege to introduce. This sensational price reduction will come as a surprise. Varieties, never before sold, are offered to you for 30 days, at 75 cents each. This is a value words cannot do justice to.

ACCOLADE - LAC. - Large rose pink lower petals carry a darker rose red central bar with fine thread lines on a soft yellow
ground. Value $\$ 3.00$ each. Sale price, ground. Value $\$ 3.00$ each. Sale price,
each AMANDA DEAN - RUF. - Beautiful white with slight pink feathered central lines on lower petals. Daintily frilled. Value $\$ 3.00$
each. Sale price, each AMAZEMENT - PL. - Brilliant vermilion red: rich yellow lower throat, blotched deep vermilion red. Value $\$ 3.00$ each. Sale price, each

ANNO DOMINI - PL. - Richest pure red. with large red blotch on white throat. Value Sale price, each........... $75 \mathrm{c}$ ANTIPHONE - LAC. - Blush white, wide soft yellow feather on lower petals. Value
$\$ 3.00$ each. Sale price, each.......................5. BEAMS OF GLADNESS - PL. - Purest deep vermilion red: lower throat soft yellow with central median lines. Value $\$ 3.00$ each. Sale price, each

BEAUTIFUL - RUF. - Softest rose pink. Lower netals soft creamy pastel yellow, Lower netals soft creamy pastel yellow,
beautifully penciled pink. Value $\$ 3.00$ each. Sale price, each DR. GEO. W. CRILE - PL. - Beautiful lavender rose pink with finely feathered rose pink throat and narrow white central thread line. Value \$3.00 each. Sale price, each. GEORGE ADE - PL. UP. - Vivid red and as striking as a torch of fire. Value $\$ 3.00$ each. Sale price, each.

GOLDEN RED - PL. - Deep vermilion red : large canary yellow throat; narrow white central maldan petals. Value $\$ 3.00$ each. Sale price, each
GOV. PINCHOT - PL. - Deen rose pink. deeper rose red central feathered extending half way out on the lower petals. Value $\$ \mathbf{3 . 0 0}$ each. Sale price, each............................. LADY LAVENDER - PL. - Lavender deepening toward the ends: throat lighter; rose lavender on lower petals, narrow white central price, each GLOXINIA - PL. - Rich deep, dark red; red blotches bordered yellow on lower dark red; red blotches bordered yellow on $\$$. $\$ 3.00$ each. Sale price, each 75c MRS. E. B. WHITCOMB-PL.-Deep apricot buff. Central feathered lines on lower petals. Value $\$ 3.00$ each. Sale price, each . . . . . . . . 75 canary
MRS. O. W. DYNES - RUF. - Soft canary yellow on upper petals; lower petals deeper with narrow pink central thread lines. Value with narrow pink central thread lines. Value
$\$ 3.00$ each. Sale price, each.........................75c
NANG PING - LAC. - Soft daffodil yellow: lower petals deeper with pink feather. Value $\$ 3.00$ each. Sale price, each......................75c ORANGE PINK - PL. - Deep bright salmon, throat. Value $\$ 3.00$ each. Sale price, each $75 \mathrm{c}$ P. D. BARNHART - PL. Upper petals light rose pink, lower deeper pink with beautiful central feather tipped white. Value $\$ 3.00$ each. Sale price, each ...............................75c PINK BELLE - PL. - Deen salmon flesh canary throat. Value $\$ 3.00$ each. Sale price, each delicate doep lose pink. Iarge blotch of purdelicate deep lose pink. Large blotch of pur \$3.00 each. Sale price, each................... let: deeper red on lower petals. Very late flowering. Value $\$ 3.00$ each. Sale price, each lavender cast. Wide feathered throat on lower netals. Value $\$ 3.00$ each. Sale price, each 75c SMOKY ORANGE - PL. - Deep orange. flaked smoky orange. Lower petals bright orange yellow with rose pink feather in throat and a narrow dark red thread line. Value $\$ 3.00$ each. Sale price, each.......................... 75c SMOKY RED - PL. - Larye smoky-red flowers. Soft red inner throat on lower petals blended with ground color. Value \$3.00 each. Sale price, each. deeper red blotches edged coppery yellow on lower petals. Narrow white central lines on all petals. Value $\$ 3.00$ each. Sale price, each SPLENDID - PL. - Delicate blushed ivory white. Lower petals deep creamy yellow price, each............................................. brilprice, each GLOXINIA - PL. - Large brilliant dark amaranth purple red: throat blotch stippled purple and edged yellow. Upper petals carry the same stippled band of yellow. Value $\$ 3.00$ each. Sale price, each..............75c
SUPERBA ROSE - PL. - Rose pink; deen red blotches, bordered soft creamy yellow, red blotches, bordered soft creamy yellow, a neat border of white. Value \$3.00 each.

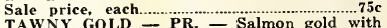
TAWNY GOLD - PR. - Salmon gold with coppery sheen, Deeper in lower throat porVERY PRETTY - LAC. - Rich lavender rose. Upper petals quite upright. Lower petals creamy white in throat. Value \$3.00 each. Sale price, each

\section{A. E. K U N D E R D GOSHEN, INDIANA, U.S. A.}




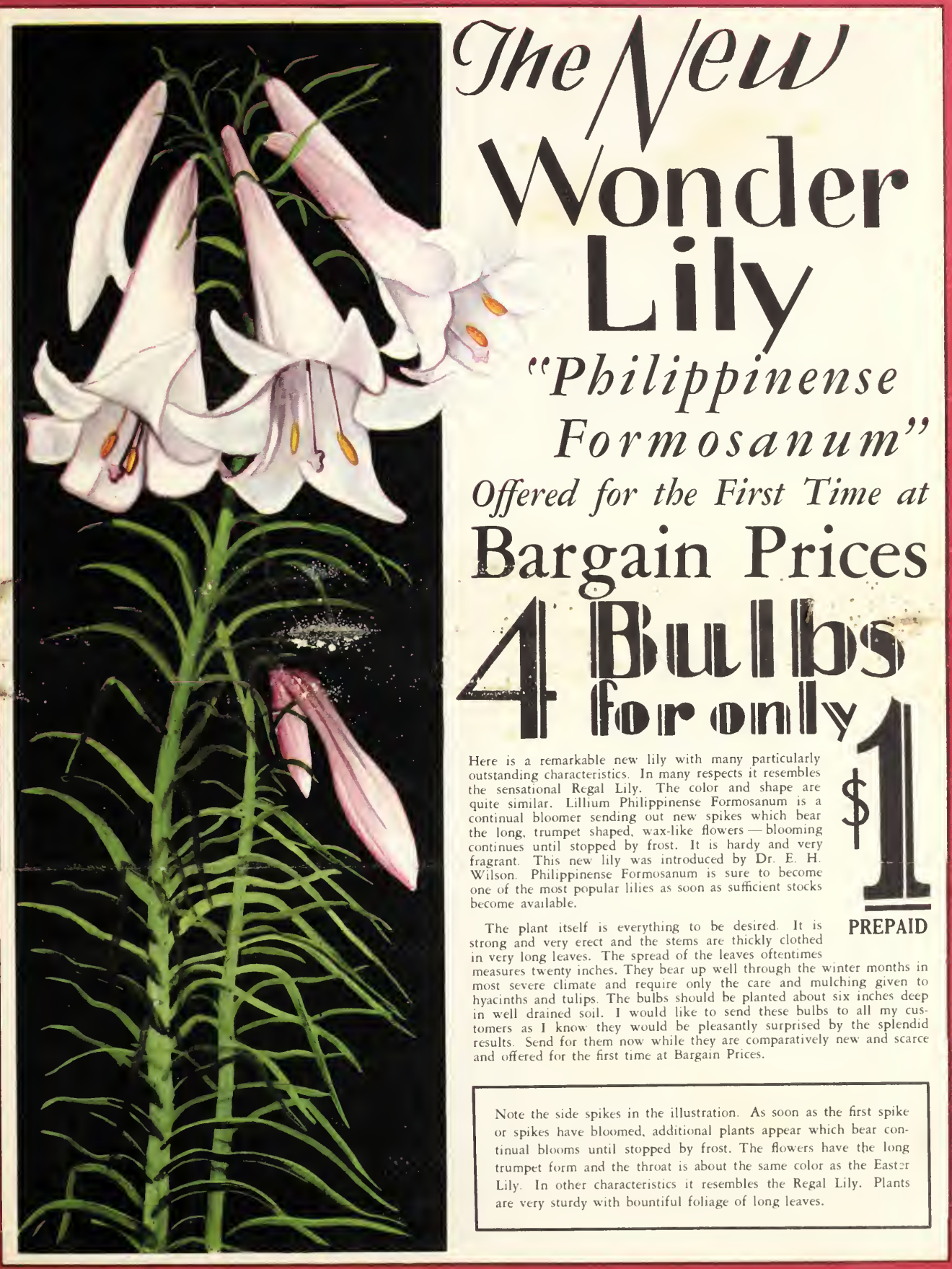




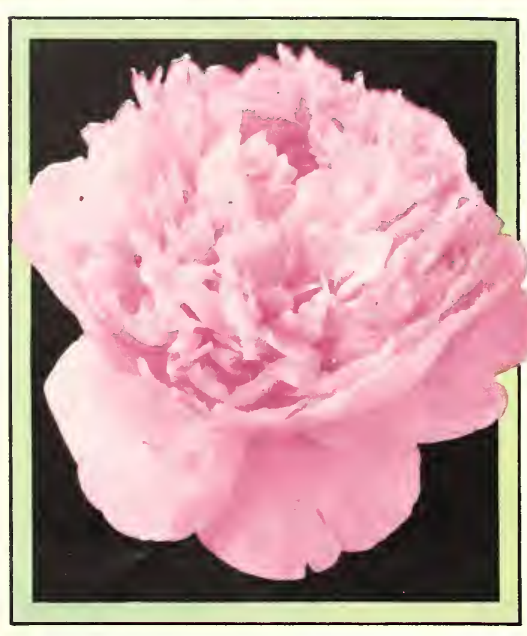

No

Bargo

gain Ever Had GreaterMerit Here is YOUR Opportunity to Secure
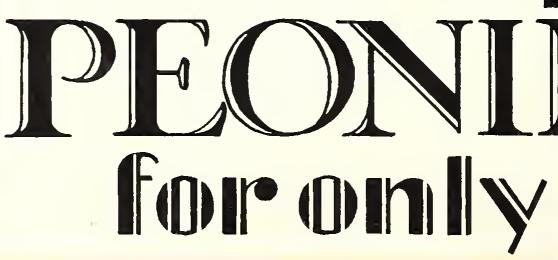

The Most Beautiful and Highest Rated Peonies in existence are included in this ONE DOLLAR collection. All roots will be properly labelled. Because of this extremely Low Price these Peonies will be shipped transportation charges only collect.

LANT peonies and you will have the finest
specimen or border flowers. The Peony retains its beautiful foliage until late fall, making it a most desirable plant both during the blooming season and after. The flowers attain a size of from ten to twelve inches in diameter. They are, in many instances, as sweet scented as roses. They are available in the most delightful colors from white to the deepest reds. The mammoth blooms sway gracefully on long slender stems. The foliage gleams with rich color of deep olive green and makes a most desirable hedge plant. Along borders, along foundations and corncrs of lawns they are ideally adapted.

Here is a bargain consisting of the finest peonies.

The divisions will be from three to five eyes and of extra fine quality. The colors will be perfectly balanced and the price makes it possible for you to enjoy the biggest peony bargain of the season. Because the price is so sensationally low peony collections will be sent transportation charges collect.

Peonies planted in the fall will make for extra root growth before severely cold weather sets in and they will appear in healthy growth in the spring.

All plants will be named and labelled.

A. E. KUNDER D, Inc. Goshen, Indiana

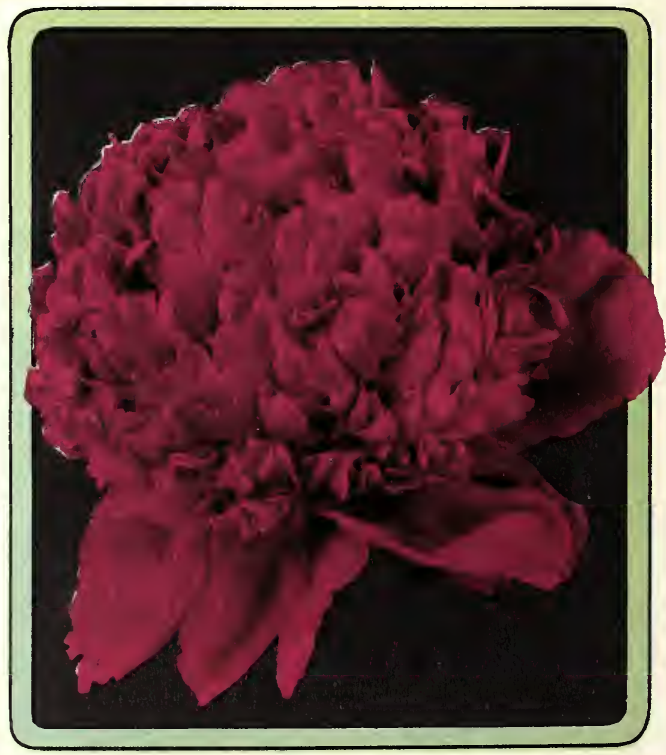




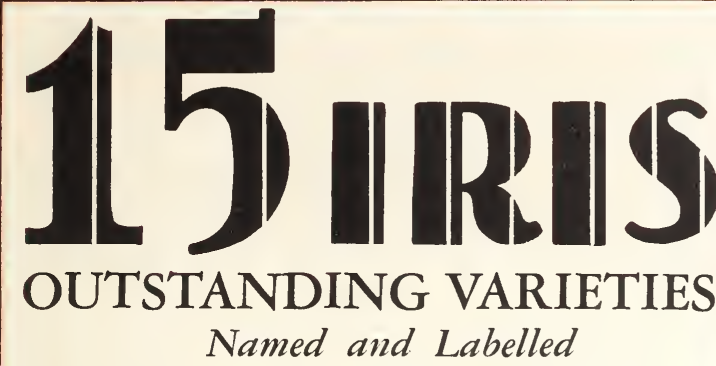

SENT TO YOU PREPAID

This is the most Sensational Offer we have ever announced on IRIS
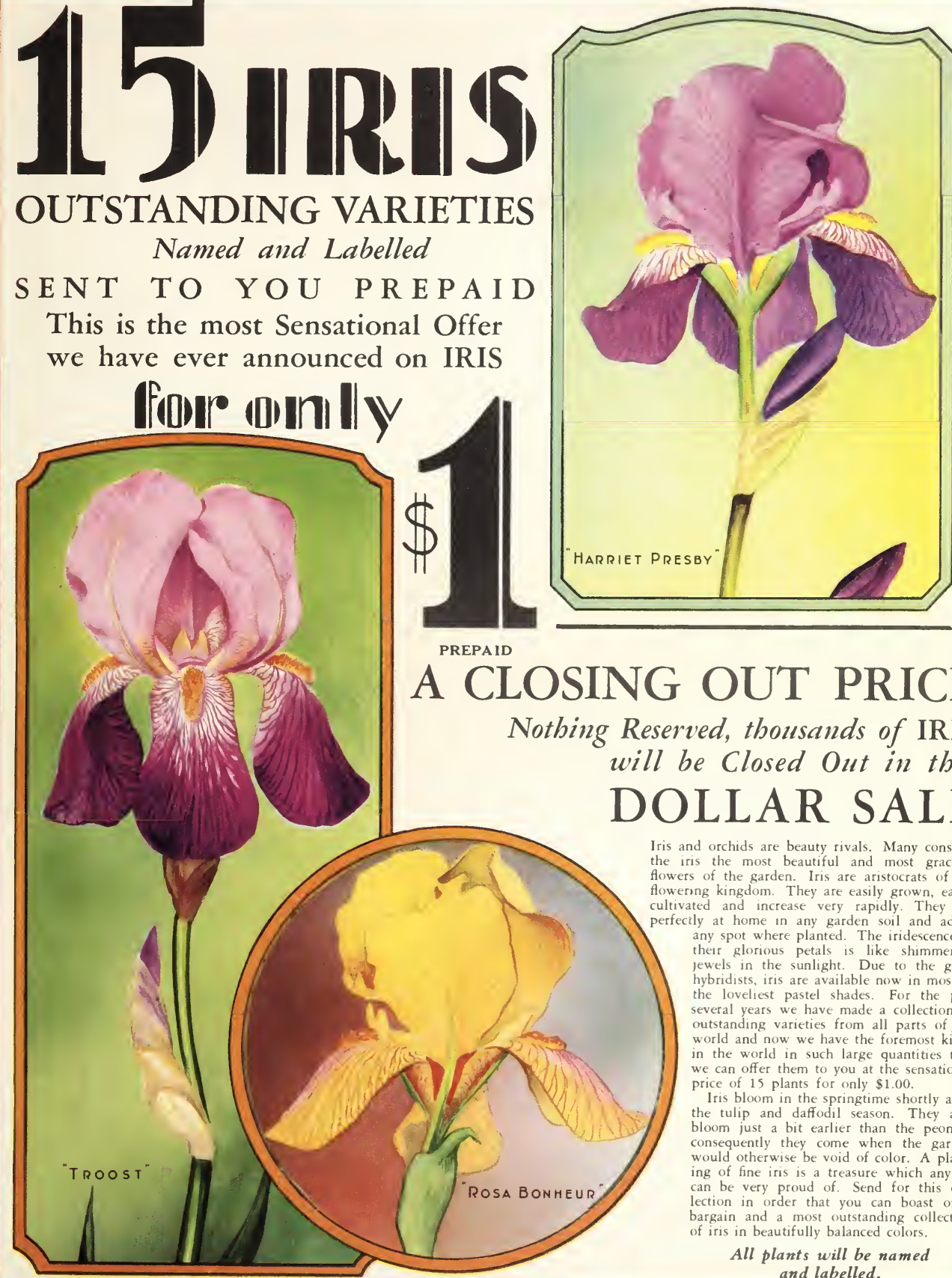

A CLOSING OUT PRICE Nothing Reserved, thousands of IRIS ill be Closed Out in this DOLLAR SALE is and orchids are beauty rivals. Many consider uris the most beautiful and most gracefu lowermg kingdom. They are easily grown, easily vated and increase very rapidly. They are any spot where planted. The iridescence of their glorious petals is like shimmering ewels in the sunlight. Due to the great hybridists, iris are available now in most of the loveliest pastel shades. For the past everal years we have made a collection of outstanding varieties from all parts of the world and now we have the foremost kinds in the world in such large quantities that we can offer them to you at the sensational price of 15 plants for only $\$ 1.00$.

Iris bloom in the springtime shortly after the tulip and daffodil season. They also bloom just a bit earlier than the peonies, consequently they come when the garden would otherwise be void of color. A planting of fine iris is a treasure which anyone can be very proud of. Send for this collection in order that you can boast of a bargain and a most outstanding collection of iris in beautifully balanced colors. All plants will be named and labelled. 


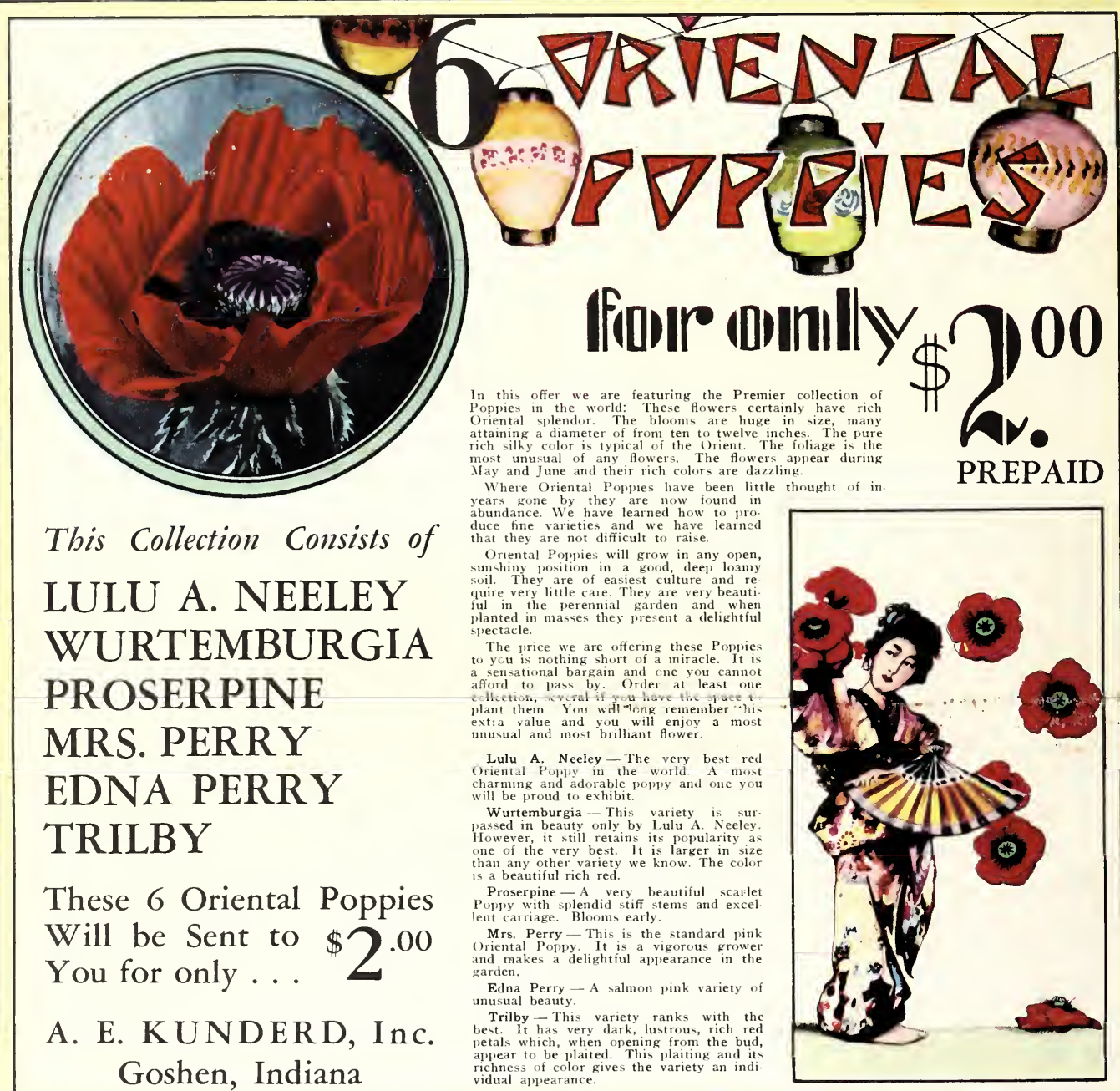
Goshen, Indiana

PLEASE USE THIS ORDER BLANK

A. E. KUNDERD, INC. Goshen, Indiana, U. S. A.

Dear Sirs: Please send me the collections checked herewith for which you

will find my remittance in the amount of \$ Lillium Philippinense Formosanum 4 bulbs for $\$ 1.00$ prepaid. Total $\$$

Peonies, 10 roots for $\$ 1.00$ ship-

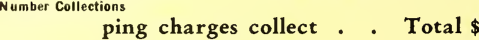

Iris, 15 rhizomes for $\$ 1.00$ prepaid Number Collections

Total \$

Oriental Poppies, 6 roots for $\$ 2.00$

prepaid . . . . . . Total \$

enclosed. 

Your Choice from Eight $\$ 300$

VARIETIES

PLEASE STATE FIRST AND SECOND CHOICE

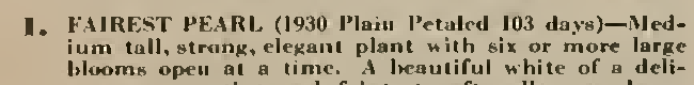

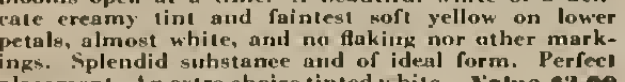

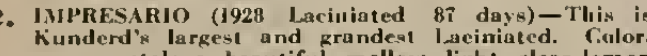

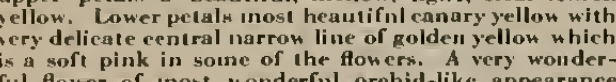

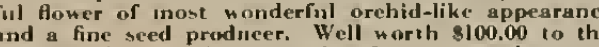

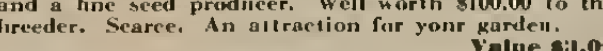

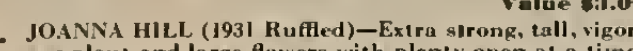

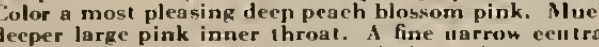
creamy white har or feather extends down the eenter of

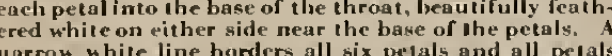

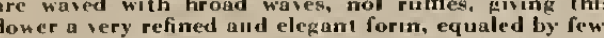

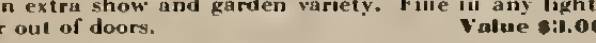

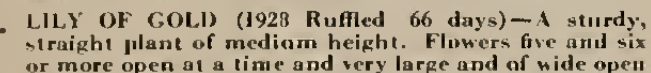
or more open at a time and very laree and of wide open
diamond form. Graeefilly and widely open upper pet-

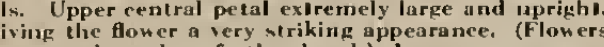

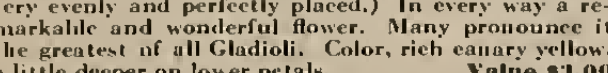

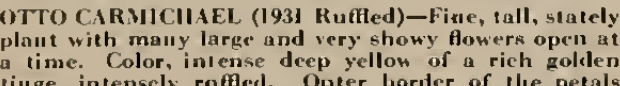

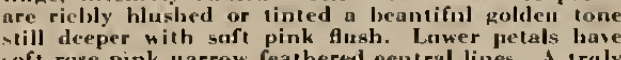

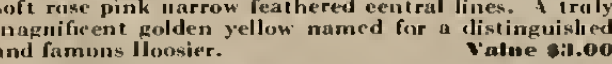

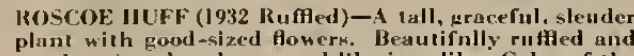

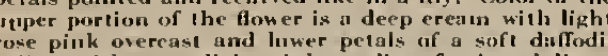

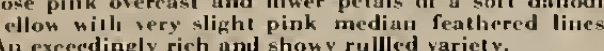
. WILLAMM RANDOLIIIIIEARST (1931 Pain Pe taled

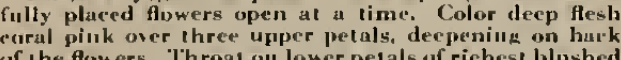

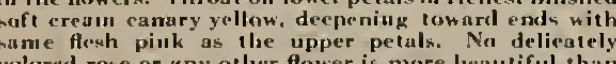

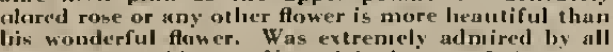

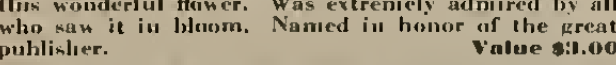

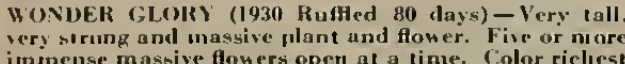

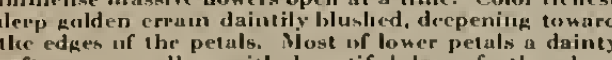

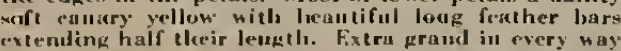

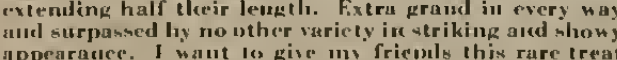

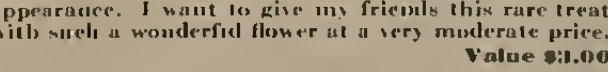

\section{Kunderdos Best Gladiol}

NOTHING RESERVED,

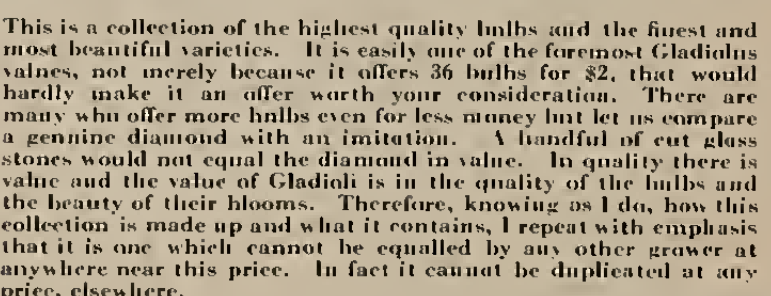

A ${ }^{\$} 300$ BULB FREE WITH EVERY COLLECTION

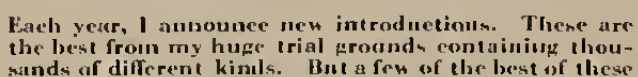

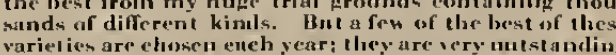

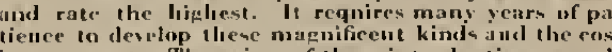

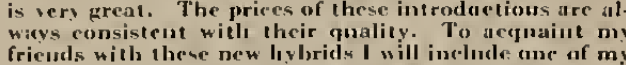

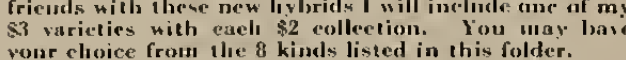

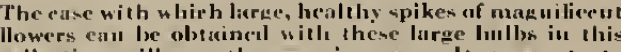

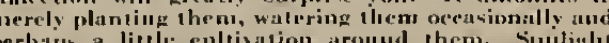

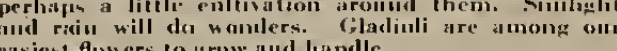

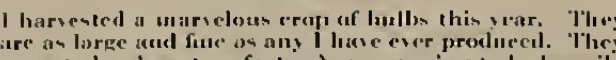

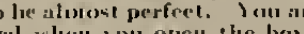

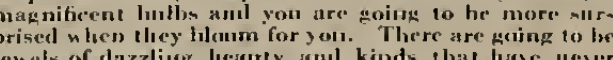

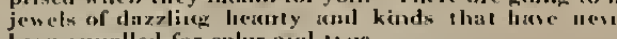

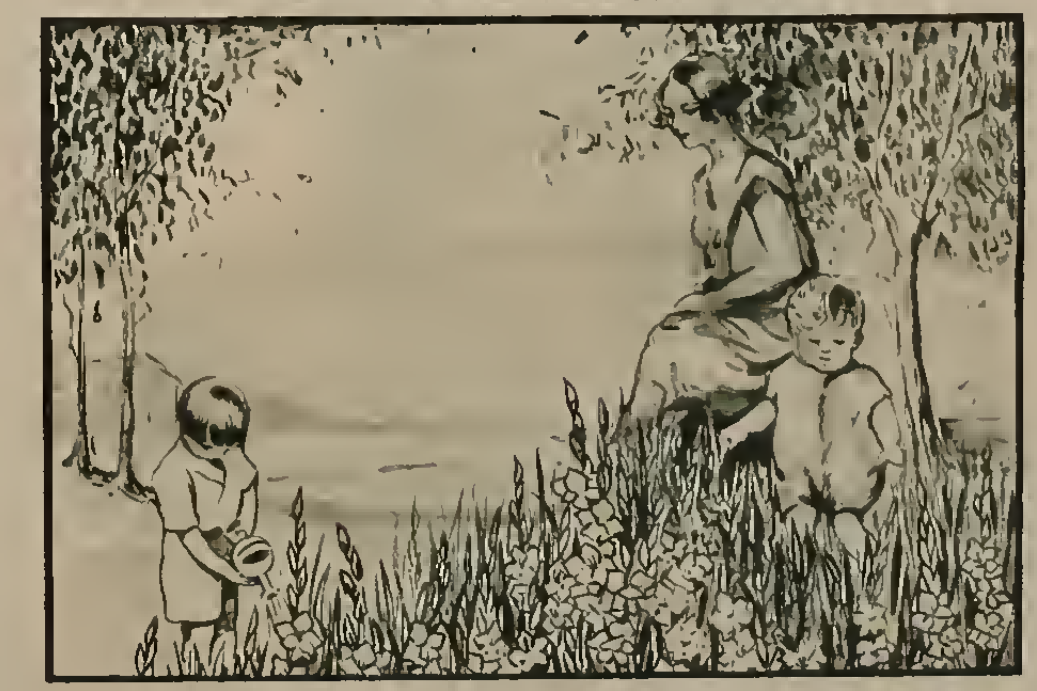

YOU CAN HAVE A GARDEN AS FINE AS THIS

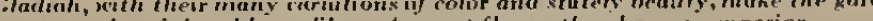

My Finest Varieties

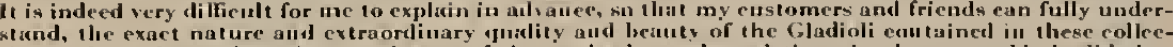

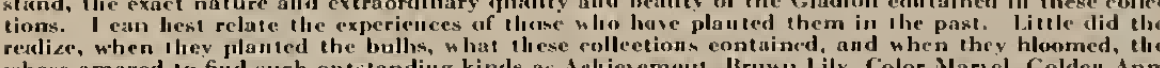

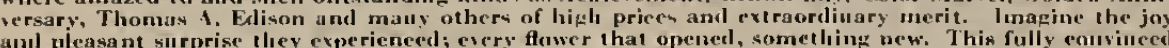

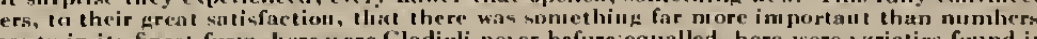

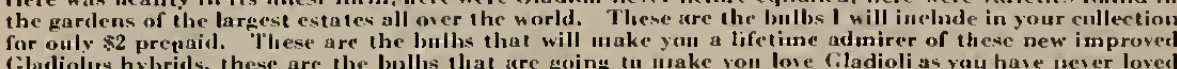

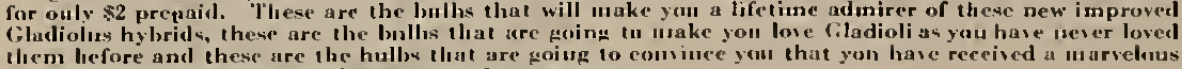



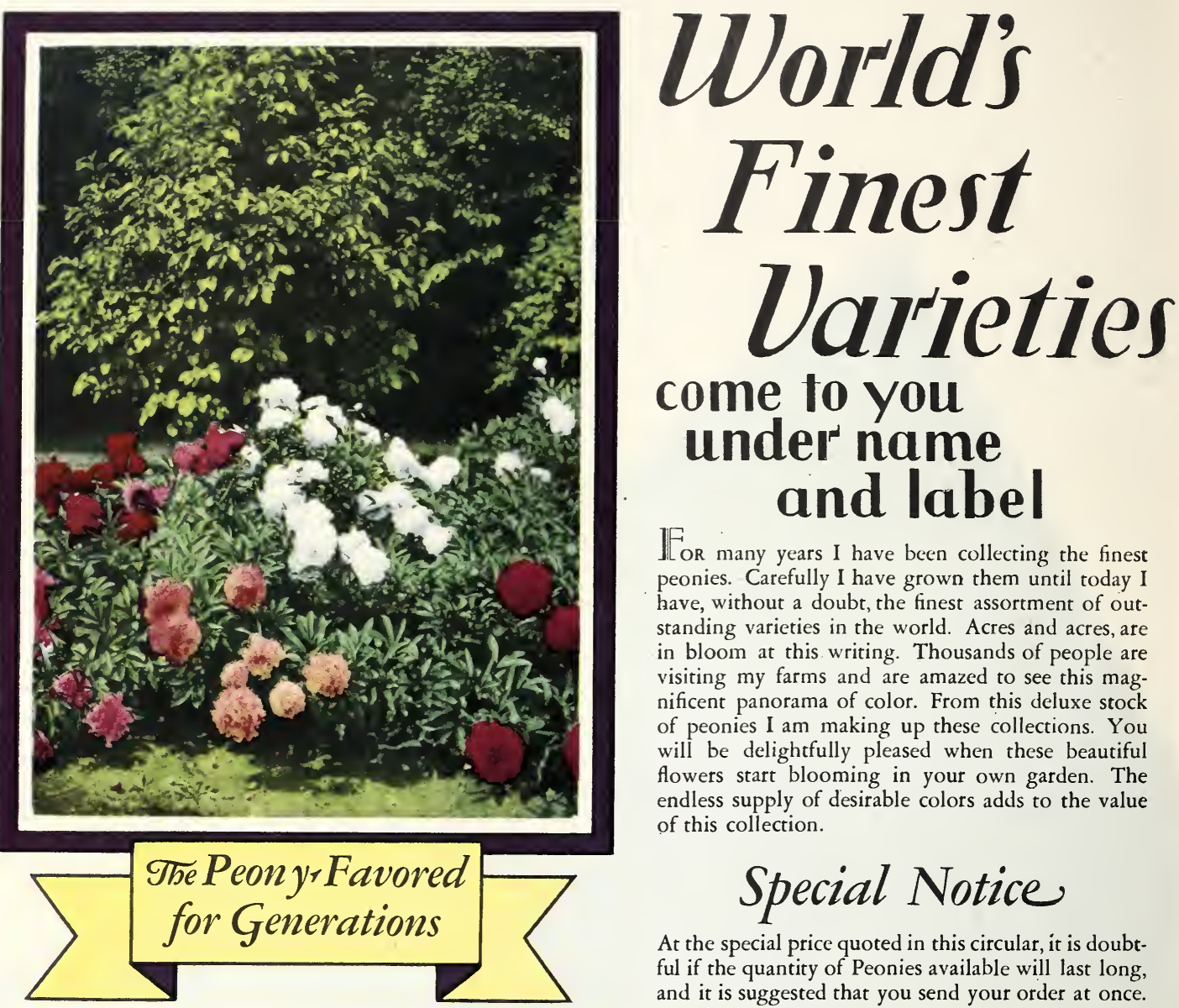

\section{come to you} under name

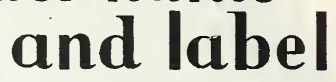

IF or many years I have been collecting the finest peonies. Carefully I have grown them until today I have, without a doubt, the finest assortment of outstanding varieties in the world. Acres and acres, are in bloom at this writing. Thousands of people are visiting my farms and are amazed to see this magnificent panorama of color. From this deluxe stock of peonies I am making up these collections. You will be delightfully pleased when these beautiful flowers start blooming in your own garden. The endless supply of desirable colors adds to the value of this collection.

\section{Special Notice}

At the special price quoted in this circular, it is doubtful if the quantity of Peonies available will last long, and it is suggested that you send your order at once.

\section{PLEASE USE THIS ORDER BLANK WHEN SENDING FOR PEONY SPECIAL}

\section{Draler MBlaml: for Iou}

A. E. KUNDERD, Goshen, Indiana

Dear Sir:

Please send me of your Special Peony Collections prepaid, in accordance with your offer in this folder.

Inclosed find $\$$

NAME
ADDRESS

CITY

STATE

\section{Drder IBlaul: for Wour Friemals}

This offer is so outstanding that you will certainly want to share the joys with others. The extra order blank will make it convenient for them to order.

\section{A. E. KUNDERD, Goshen, Indiana.}

Dear Sir:

Please send me Special Peony Collections prepaid, in accordance with your special offer for which I am inclosing remittance for $\$$

NAME

STREET or R. F. D. P. O. BOX 
$2)$

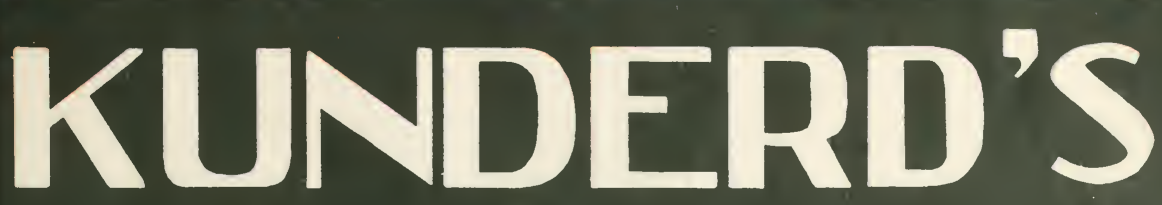

(2)
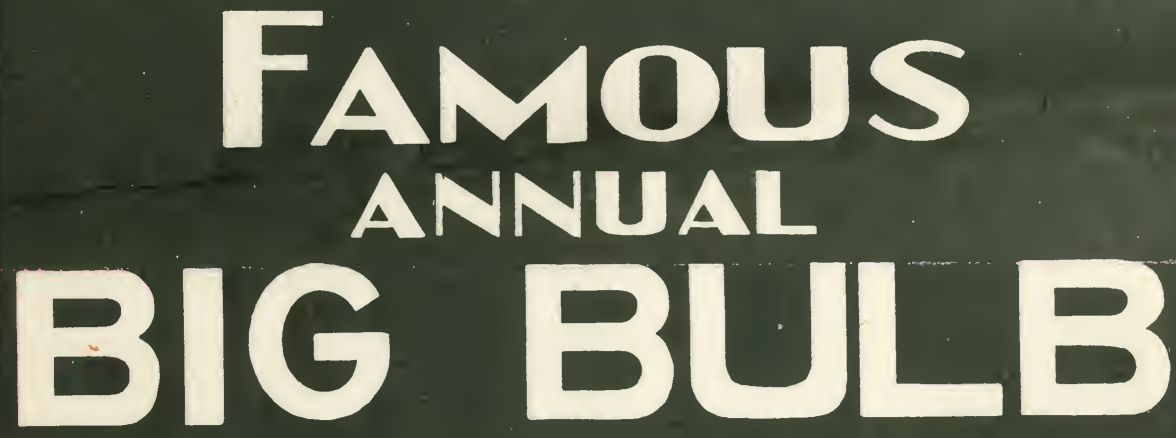

2

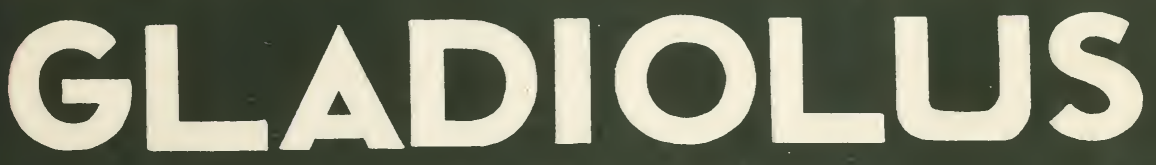

2

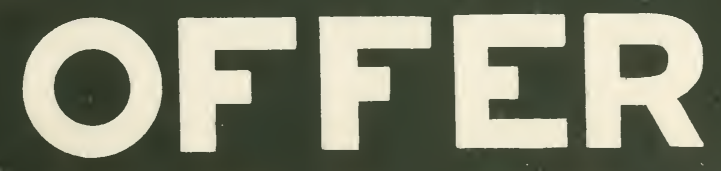

pRIG zS GRASH TO LOWIST LEVIL

Biğger - Better More Sensational READ ACT 

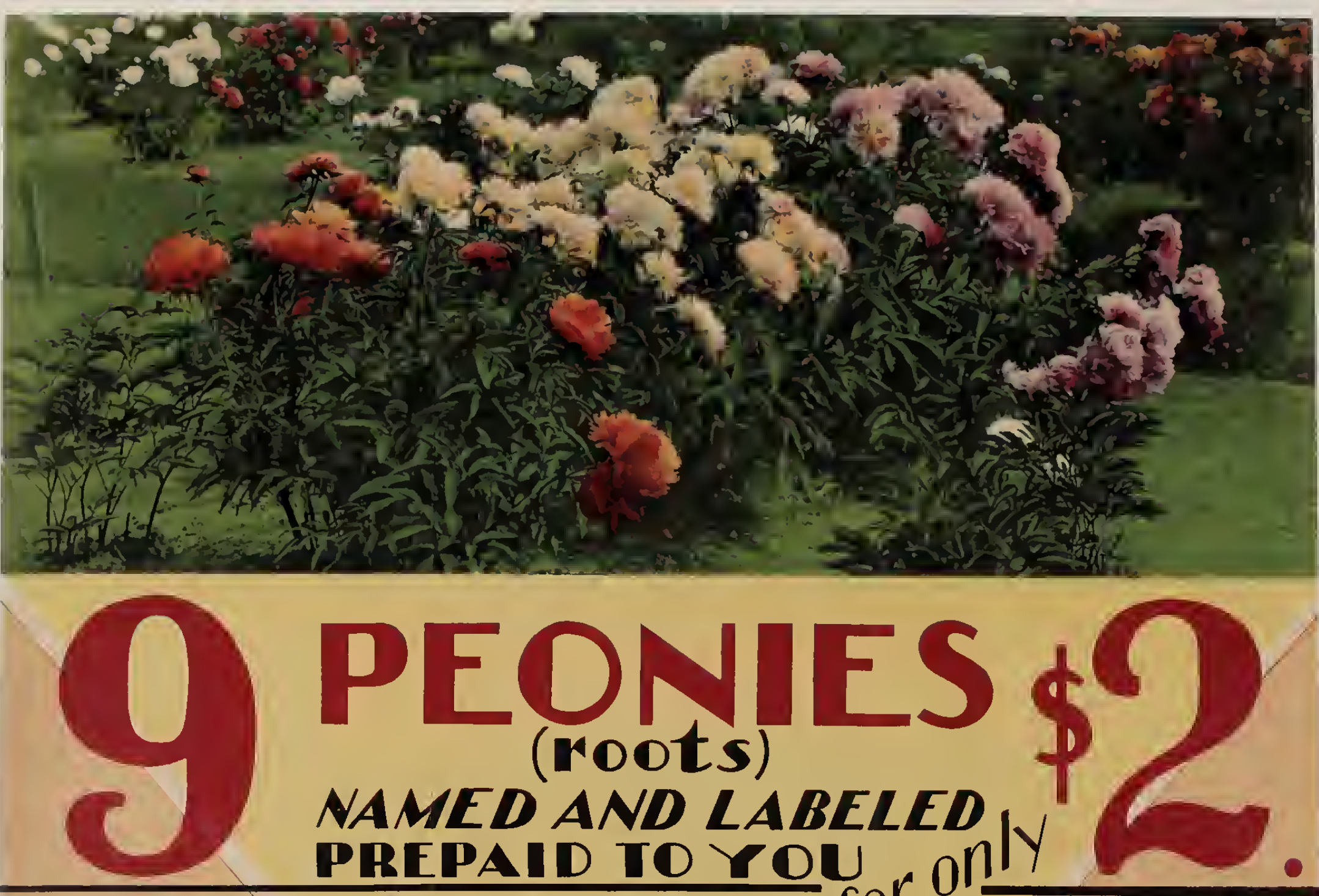

The PEONY

-a Favorite

for Generations

Peonies can be used to beautify your garden and lawn. They can also be used in hedges or for border plantings, around the foundation of your home and arc suitable in almost any Incation. Each collection is made up so as to give a good assortment of

Peonics have long been old time favorites, but the improvement in he modern varicties over those of grandmother's garden is very proounced. The blooms are larger and are fincr in shape and color. The foliage remains benutiful, even when he flowers are gone and until frosts in latc fall. Pconics arc, without a doubt, onc of the finest and most pretentious of all ornamental flowers.
THIS is your opportunity to take advantage of onc $\quad 0$

of the most sensational flower bargains we have ever been able to make. We offer an exceedingly big value in the choicest of Peonies grown. Business conditions only make this possible.

Peonies have shown startling improvements Juc to the efforts of the greatest of our Peony specialists and today they are considered the most magnificent perennial flowers and are far beyond thearverage conception of beauty - Peonies today are magnificent in color. varying types, size and many of them are as sweet scented as roses.

We offer yon 9 varieties all different, fund maynificent Peonies, properly labeled for identification, and sent prepaid to your door, safe arrival guaranteed, for the small sum of only $\$ 2.00$, or if your space is limited and you cannot take advantage of the larger collection offered, YOU MIAY HAVE 4 FOR $\$ 1.00$.

\section{PEONIES}

\section{are Permanent}

Once planted, Pconics can be lef

almost alsne. They are permanen Howers. Ycar after year they will repeat themselves, growing finer anc fner as they become betrer estab. lished. Each ycar more blooms appea and there seems to be no end to thei dazzling beaucy and perfection. Forcunatcly, the foliage of the peony remains delightfully green through the summer. The peony is an earl bloomer, the blossoms appeating lang with the late iris and-other A. E. KUNDERD shaded places. They beautify every spot in which they arc planted and as a hedge plant, they are practical.

\section{At this low price you can have} an entire hedoe- of Peonies.

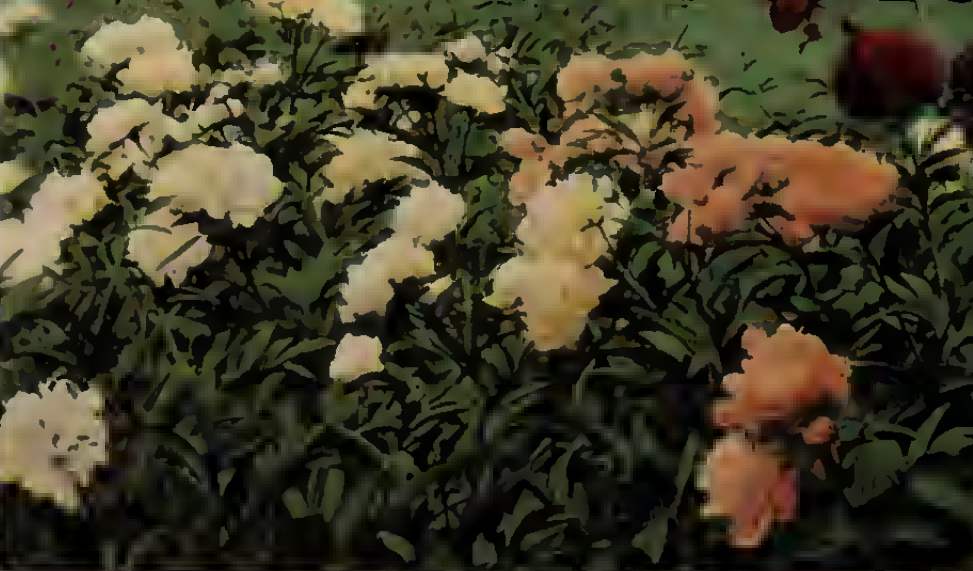




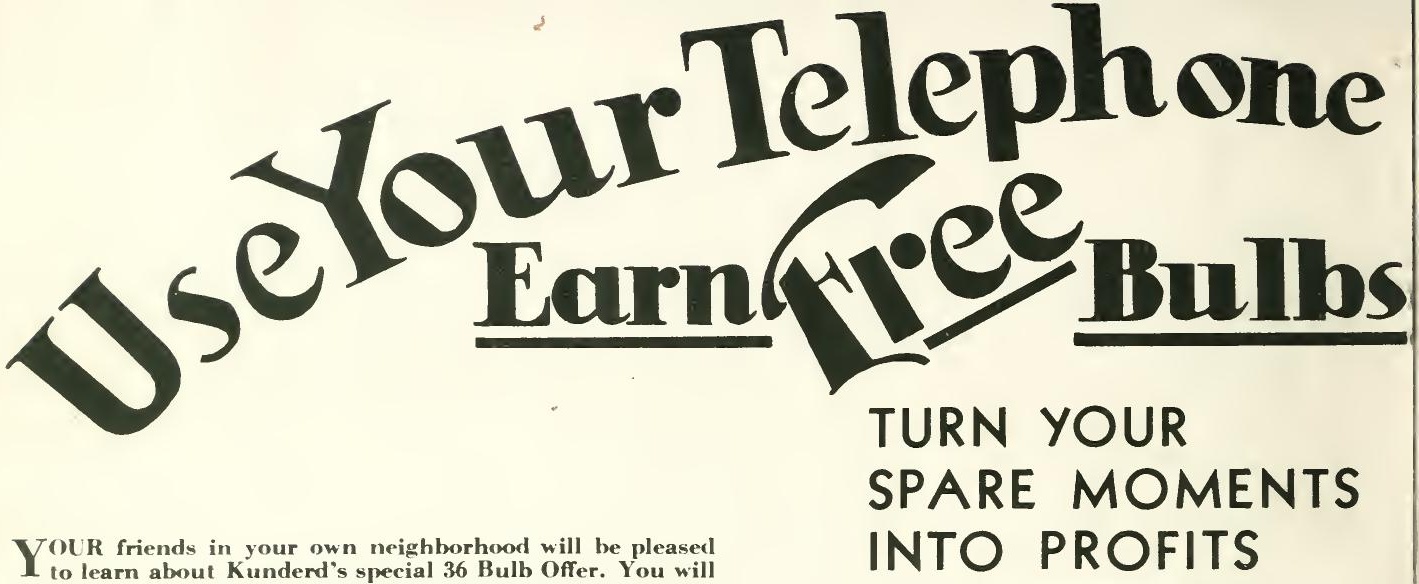

1 to learn about Kunderd's special 36 Bulb Offer. You will experience no difficulty in getting orders for five or more collections at $\$ 2$ each. Sit down to your telephone or call on them; explain the special offer to them. You will be very much surprised how pleased they will be that you called their attention to this unusual opportunity to secure these extraordinary bulbs including a three-dollar variety for only $\$ 2$ prepaid.

When you secure five orders send in the names and addresses along with the remittances of ten dollars and we will send a collection to you absolutely FREE. How could you spend a few moments with greater pleasure and more profitably? What could be easier than this? Your friends are going to be greatly pleased when these flowers bloon and they are always going to remember your kindness.

Of course you do not have to sell these collections unless you wish but you will be doing your friends a great favor if you do. You may send in only $\$ 2$ for this collection or you may secure it free by sending in five orders from friends or acquaintances. You could profitably sell many more collections and for every 5 orders you will receive an extra collection for yourself. If you secure several sets of $\mathbf{5}$ collections I will send you still other extra fine varieties, in addition to the extra collections for yourself.

Delivery will be made as quickly as the weather permits.

\section{ORDER BLANK FOR SPECIAL BULB COLLECTION}

\section{A. E. KUNDERD, Goshen, Indiana}

Dear Sir: Please send me collections of 36

large bulbs including my choice of the $\$ 3.00$ bulb indicated on the right.

You will find my remittance to the amount of

inclosed in payment of these collections.

Name

Address.

City State

Notice: Be sure to state your first and second choice of the \$3.00 bulb I am to send you
Place a cross

in square opposite the variety you wish

Fairest Pearl (1930 Plain Petaled 103 days)

Impresario (1928 Laciniated 87 days)

Joanna Hill (1931 Ruffled)

Lily of Gold (1928 Ruffled 66 days)

Otto Carmichael (1931 Ruffled)

Roscoe Huff (1932 Ruffled)

William Randolph Hearst (1931 Plain Petaled)

Wonder Glory (1930 Ruffled 80 days) 



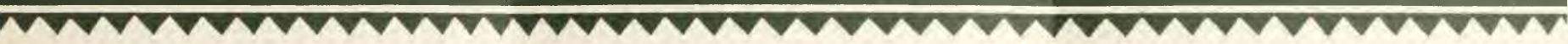
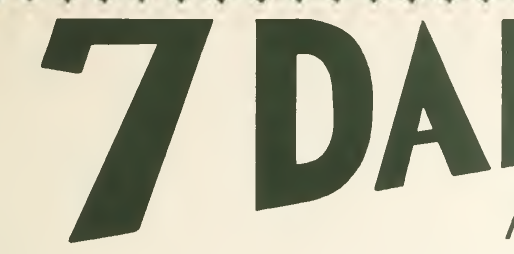

HLIAS

NOTWOALIKE

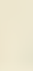

IWILL

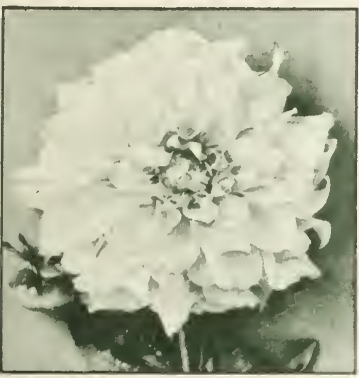

Peony Flowercd Dahlia

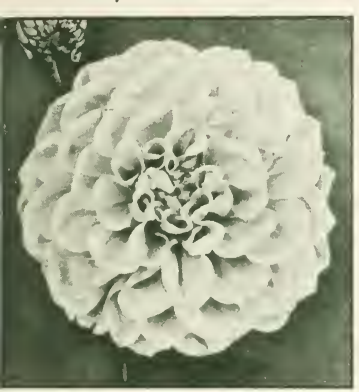

SEND YOU A

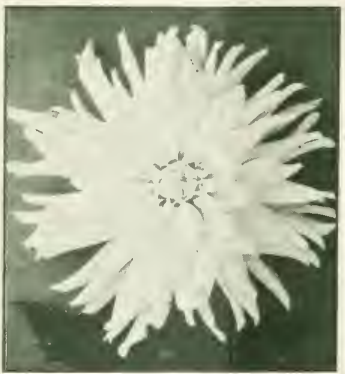

Cactus Dahlia

Pompon Dahlia

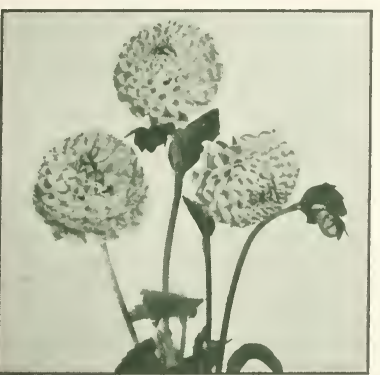

The beautiful varietie DECORATIVE DAHLIAS

1 doubt if there are many flowers enjoying greater popularity than dahlias and when more people see and learn ahout the new. fancy types there is nure to he more garden spaere set four different varieties of decorative dahlias, types which have broad. flat and nearly straight petala, arranged somewhat irregularly. These varietiea are not apherieal in ahapc. like the Show Dahlia, hut are inclined to be flat and massive and
full in the eenter.

In this group will be (Pride of California) a beantiful. decp red dahlia which grows $51 / 2$ feet tall and hears flowers 6 inches across the hissom - (Monnie hrae) another gorgeous variet ful $\mathrm{C}$ (unt) in the lareet duhlia ever urodured of apriot color with pletes this group and is one of the very hest and mont ahowy dahlias grown. It is of deep mauve-pink growing on strong.
A BARGAIN PRICE THAT

All roots will be carefully labelled. They will come to you prepaid in finc condilion for planting. Southern shipments will be made in early 1 pril and northern shipments late planting. Southern shipments will be made in early

A. E. KUNDERD $\boldsymbol{\gamma}$

$n$

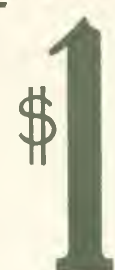

50

Prepaid FORONLY

ROOTS

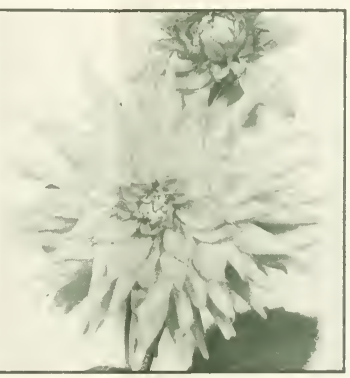

Cactus Dahlia

in this Collection POMPON DAHLIA

I am alao ineluding in this collertion a delightful little Pompoom and hloom and bloom. They juat love to be pieked and there seems to be an endless supply of blooms for cutting. Broomfield), a beautiful white flower that will thrill you with PEONY FLOWERED DAHLIA

heeley). one of the most loved and finest varieties of golden yellow color. It has a long stem as graceful as can loe imagined

No group of 7 dahlias eould surpass this collection for color appear in your garden. Sce what a fine asoort ment I am
offering to you in the form of FIRST GR IDE ROOTS for only sicnon you
Last, to complete this outstanding group of 7 dahlias I have

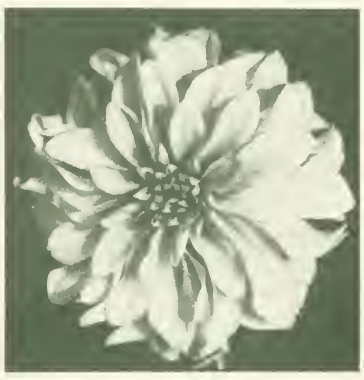

Decorative Dahlia

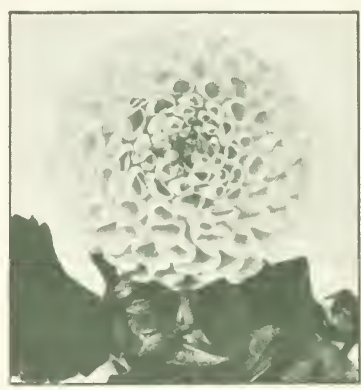

RECORDS lt is doubtful if anyo else is offering 7 dahias of this quality at anywhere near this price. When you compare regular prices with the price I am quoting for seven outstanding varieties, under name and label, you will appreciate this unusual offer. This is a suggestion that you act immediately. Orders will be

$"$ GOSHEN, INDIANA 

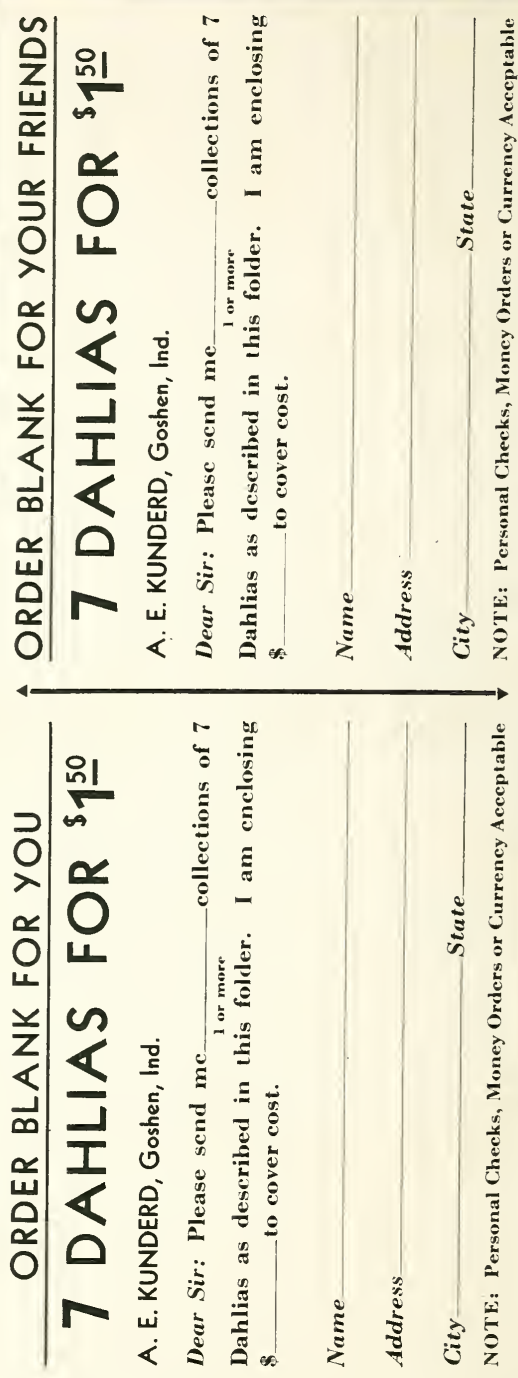


\section{HOW TO PLANT AND CARE FOR DAHLIAS}

Dahdias ean be planted in most any kind of soil but should have sunlight at least a part of the day. Plant the roots about 6 inches deep in a horizontal position (do not stand roots on end) and suffieiently far apart to prevent erowding of plants when grown. Spade the ground from eight to ten inehes deep, working the soil very thoroughly. If manure is used in planting be sure that the root does not eome in direet eontaet with it. The time of planting dahlias varies aecording to loeation, whether your spot is open or sheltered. Dahlias may be planted any time after the danger of frost has passed. and in ordinary eonditions they will bloom in from six to eight weeks. It is best to wait until the ground beeomes warm.

\section{These Roots Will Bloom in from 6 to 8 Weeks After Planting}

Dahlias are very easy to grow. In inevperieneed grower should have no diffieulty in produeing magnifieent flowers. Working the soil at the base of the plant and adding a bit of eommercial fertilizer will offer its reward. To obtain large blooms disbudding is reeommended. Do not plant dahlias in an unsheltered place at the merey of severe winds. The stems of dahlias are somewhat brittle and will break under too great a strain. 

ORDER SHEET

\section{A. E. Kunderd, Goshen, Ind., U. S. A.}

\section{Please forward to}

Name.

$\dot{x}$ Street.

wi Post Office

County. is

Please write name and address plainly, and fill in all blanks carefully, attach price to each article and add up accurately. If no objection, We substitute a similar or better variety when out of kinds ordered. Order early. Re Please write letter on separate sheet.

\section{QUANTITY \\ VARIETY ORDERED}

\section{R. F. D. No. \\ P. O. Box.}

State

Express Office.

\section{PRICE} Dollars Cents

TOTAL 



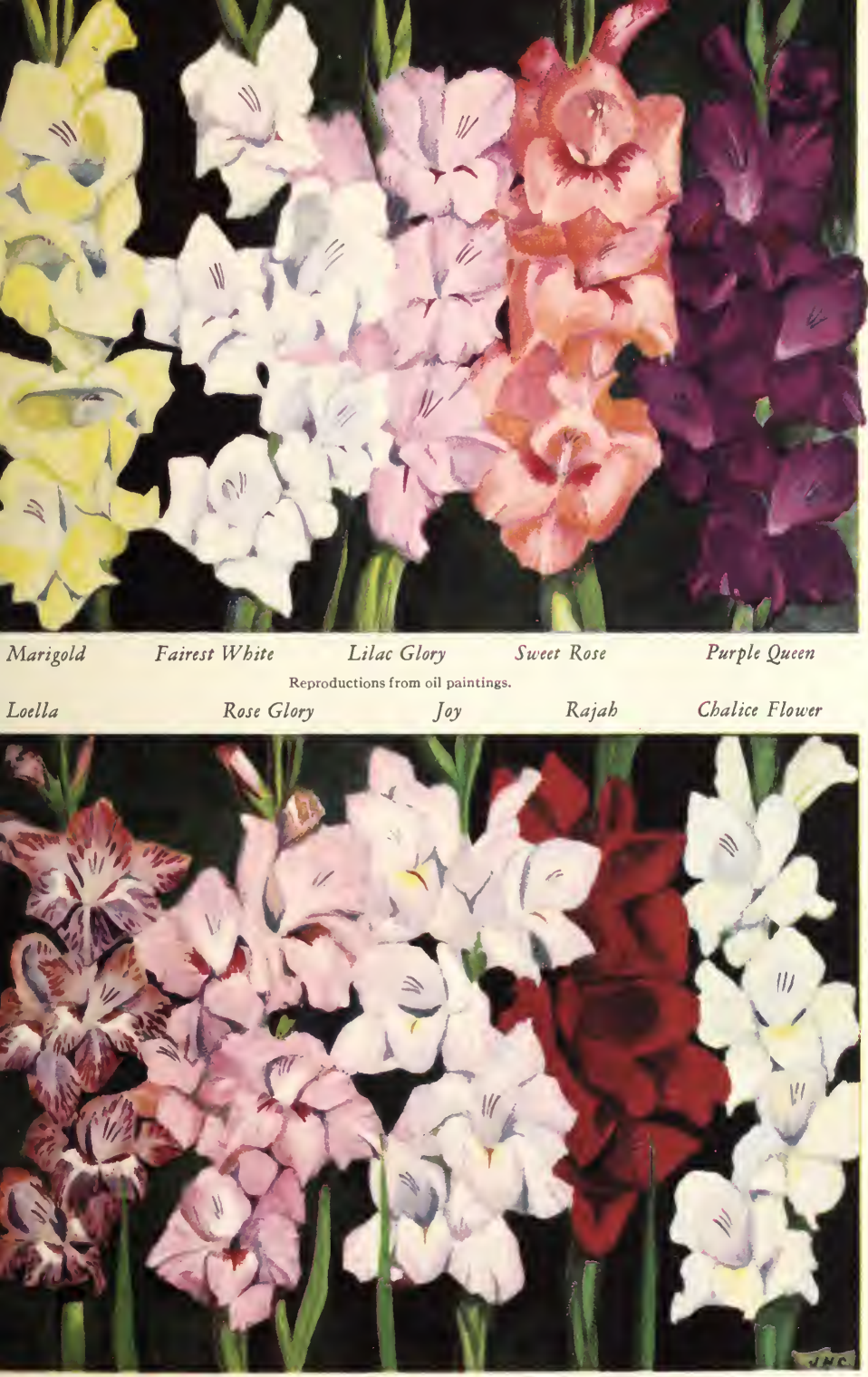


